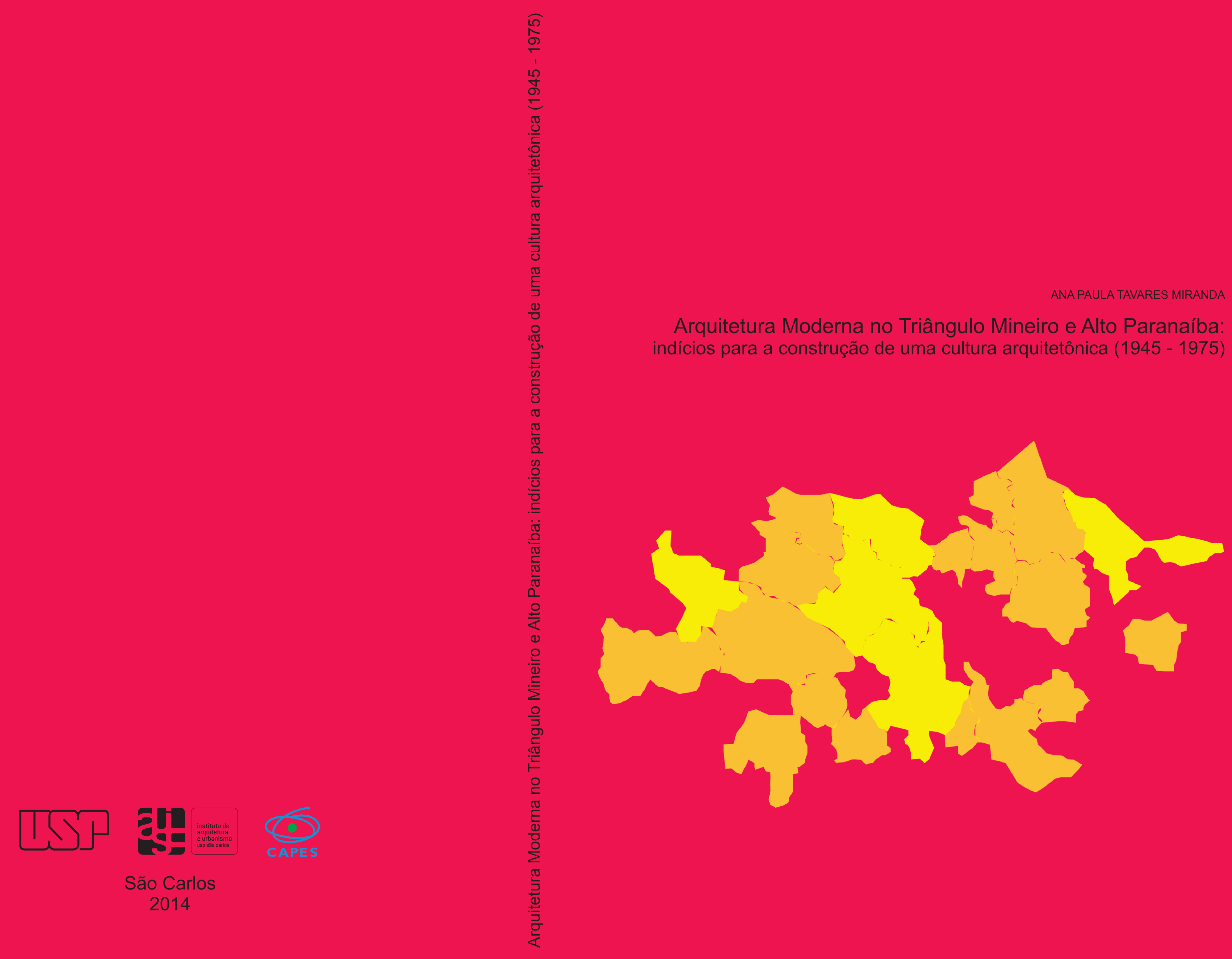




\section{Arquitetura Moderna no Triângulo Mineiro e Alto Paranaíba: indícios para a construção de uma cultura arquitetônica $(1945-1975)$}

Dissertação de Mestrado apresentada ao Programa de PósGraduação do Instituto de Arquitetura e Urbanismo da Universidade de São Paulo - IAU/USP, para obtenção do título de Mestre em Arquitetura e Urbanismo.

Área de Concentração:

Teoria e História da Arquitetura e Urbanismo

Orientador:

Prof. Dr. Carlos A. Ferreira Martins

Apoio:

Capes - Coordenação de Aperfeiçoamento de Pessoal do Nível Superior 
AUTORIZO A REPRODUÇÃO TOTAL OU PARCIAL DESTE TRABALHO, POR QUALQUER MEIO CONVENCIONAL OU ELETRONNICO, PARA FINS DE ESTUDO E PESQUISA, DESDE QUE CITADA A FONTE.

Arte da Capa: Ana Paula Tavares Miranda

Ficha catalográfica preparada pela Seção de Tratamento da Informação do Serviço de Biblioteca - EESC/USP:

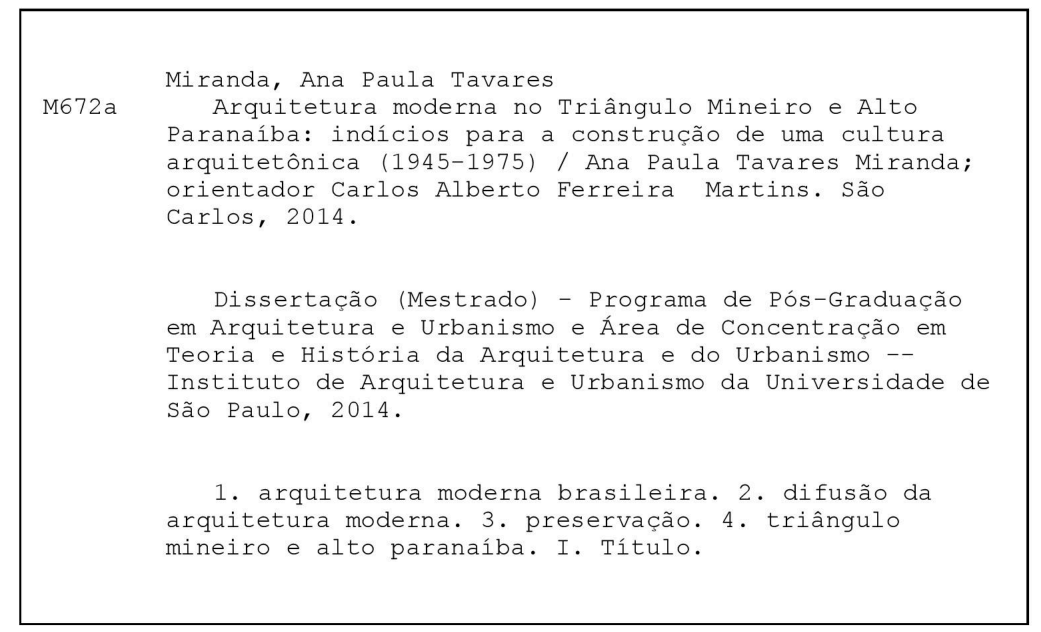




\section{FOLHA DE JULGAMENTO}

Candidata: Arquiteta e Urbanista Ana Paula Tavares Miranda

Título da dissertação: "Arquitetura Moderna no Triângulo Mineiro e Alto Paranaíba: indícios para a construção de uma cultura arquitetônica (1945-1975)".

Data da defesa: $25 / 04 / 2014$.

Comissão Julgadora:

Resultado:

Prof. Tit. Carlos Alberto Ferreira Martins (orientador) (Instituto de Arquitetura e Urbanismo - USP)

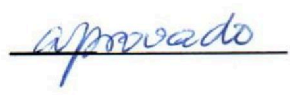

Prof. Dr. Francisco Sales Trajano Filho

(Instituto de Arquitetura e Urbanismo - USP)

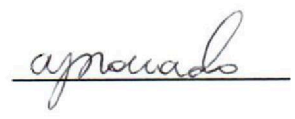

Profa. Dra. Maria Beatriz Camargo Cappello

APHOUARO

(Faculdade de Arquitetura e Urbanismo e Design-UFU)

Presidente e Coordenador do Programa de Pós-Graduação em Arquitetura Urbanismo: Professor Associado Márcio Minto Fabricio 

Para minha mãe,

O dar-vos quanto tenho e quanto posso, Que quanto mais vos pago, mais vos devo.

(Camões) 



\section{Agradecimentos:}

Agradeço o meu orientador, o professor Carlos Alberto Ferreira Martins.

Aos demais integrantes da banca, o professor Lu de Laurentiz e o professor Sales Trajano.

À professora e amiga Bia Cappello, que esteve presente nessa pesquisa, desde a época da graduação, na Faculdade de Arquitetura e Urbanismo da UFU - FAUeD-UFU.

À Faculdade de Arquitetura e Urbanismo da FAUeD-UFU, local onde me despertou o gosto pela pesquisa, em especial ao Núcleo de Teoria e História da Arquitetura e Urbanismo - NUTHAU, que me concedeu a utilização do material usado nesse mestrado.

Às professoras Patrícia Pimenta Ribeiro e Maria Eliza Guerra da FAUeD-UFU. Esse trabalho não seria possível sem suas pesquisas pioneiras sobre arquitetura moderna no Triângulo Mineiro. Da mesma forma, agradeço ao professor Lu de Laurentiz e à professora Bia Cappello por seus respectivos trabalhos junto ao tema.

Aos amigos que fiz durante minha estadia em São Carlos, obrigada pelas grandes e pequenas contribuições, em especial: Adriana Almeida, Pedro Mattia, Marieli Lukiantchuki, Rodrigo Jabur e Tássia Marques.

Aos amigos Ariel Lazzarin, Emilliano Freitas e Juscelino Machado, pelas conversas estimulantes sobre arquitetura e arte.

À minha família, obrigada pela compreensão: minha mãe Iraci, meu pai Celso, meus irmãos Mariana e Lucas.

À Capes - Coordenação de Aperfeiçoamento de Pessoal de Nível Superior, pelo auxílio financeiro. Ao Instituto de Arquitetura e Urbanismo da Universidade de São Paulo - IAU-USP, pela oportunidade. 



\section{RESUMO}

MIRANDA. Ana Paula Tavares. Arquitetura Moderna no Triângulo Mineiro e Alto Paranaíba: indícios para a construção de uma cultura arquitetônica (1945 - 1975). 2014. 247p. Dissertação (mestrado) - Instituto de Arquitetura e Urbanismo, Universidade de São Paulo, São Carlos.

Esse trabalho objetiva avançar nas pesquisas acerca da difusão da arquitetura moderna brasileira para fora dos grandes centros, descobrindo seus reflexos ante as peculiaridades locais da mesorregião mineira do Triângulo Mineiro e Alto Paranaíba, identificando, além dos seus protagonistas, os vários mecanismos de apropriação da nova linguagem projetual inserida, que também se refletem na produção de novos valores, novas formas, novos procedimentos técnicos e nos diálogos com a produção dos grandes centros. Parte da arquitetura moderna documentada em vinte e uma cidades da mesorregião pelo projeto de pesquisa intitulado "Documentação da Arquitetura Moderna no Triângulo Mineiro e Alto Paranaíba: História e Preservação", desenvolvido pelo Núcleo de Pesquisa em Teoria e História da Arquitetura e Urbanismo (NUTHAU), da Faculdade de Arquitetura, Urbanismo e Design da Universidade Federal de Uberlândia (FAUeDUFU). O trabalho foi desenvolvido no curso de mestrado em Teoria e História da Arquitetura e Urbanismo, do Instituto de Arquitetura e Urbanismo da Universidade de São Paulo (IAU/USP), com auxílio da Coordenação de Aperfeiçoamento de Pessoal de Nível Superior (Capes).

Palavras-chave: arquitetura moderna brasileira; difusão da arquitetura moderna; preservação; Triângulo Mineiro e Alto Paranaíba.

\section{ABSTRACT}

MIRANDA. Ana Paula Tavares. Modern Architecture in the Triângulo Mineiro and Alto Paranaína region: some indications for the development of an architectural culture. 2014. 247p. Dissertation (master's degree) - Instituto de Arquitetura e Urbanismo, Universidade de São Paulo, São Carlos.

This work, which is entitled "Modern Architecture in the Triângulo Mineiro and Alto Paranaína region: some indications for the development of an architectural culture", aims at progressing the research on the spread of Brazilian modern architecture outside major centers, finding out its consequences on local peculiarities of the Triângulo Mineiro and Alto Paranaíba mesoregion and also identifying - in addition to its protagonists -, the numerous mechanisms for appropriation of the new projectual language added, which is reflected in the production of new values, new forms and new technical procedures as well as in the dialogues with production from major centers. Part of the modern architecture was documented in twenty-one mesoregion cities through a research project entitled "Documentation of Modern Architecture in Triângulo Mineiro and Alto Paranaina: History and Preservation", undertaken by the Center for Research in Theory and History of Architecture and Urbanism (NUTHAU, in Portuguese), from the School of Architecture, Urbanism 
and Design at the Federal Univerity of Triângulo Mineiro (FAUeD-UFU, in Portuguese). The work was developed at the Master's Program in Theory and History of Architecture and Urbanism Architecture and Urbanism Institute of the University of São Paulo (IAU/USP) with support from CAPES (Coordination for Improvement of Higher Education Personnel).

Key-words: brasilian modern architecture; brazilian modern architecture spread; preservation; Triângulo Mineiro e Alto Paranaíba. 


\section{Sumário}

INTRODUÇÃO.

\section{CAPÍTULO 1 - O TRIÂNGULO MINEIRO E ALTO PARANAÍBA: ELEMENTOS DE CONTEXTO.}

Características Territoriais e Geográficas.

O Triângulo no Processo de Interiorização do Brasil e o Início das Relações com São Paulo.

A Implantação das Ferrovias, Estradas de Rodagem e a Dinâmica entre as cidades.

O Triângulo Mineiro a Partir do Plano de Metas de JK.

\section{CAPÍTULO 2 - OS PRIMEIROS PASSOS PARA A PRODUÇÃO DE UMA ARQUITETURA MODERNA.}

Um Imaginário Moderno na Dinâmica Construtiva do Triângulo.

Marco Inicial: a Fonte Andrade Júnior no Conjunto Paisagístico para o Parque da Estância do Barreiro de Araxá - Francisco Bolonha.

O Complexo Industrial da Fertiza - Raphael Hardy Filho. 101

Os Arquitetos Residentes.

\section{CAPÍTULO 3 - ARQUITETURA MODERNA NO TRIÂNGULO MINEIRO E ALTO PARANAÍBA} PÓS-60.

A Estação Ferroviária de Oswaldo Arthur Bratke em Uberlândia: Arquitetura Ligada à Cultura de Transportes.

A Verticalização nos Anos de 1960

A Vila de Operadores de Jaguara: o Alcance da Arquitetura Moderna nas Pequenas Cidades......

A Igreja Espírito Santo do Cerrado.

PARA CONCLUIR E SEGUIR. 



\section{Introdução}

A arquitetura moderna brasileira se notabilizou internacionalmente por ter seguido um caminho próprio, que muito se deve as peculiaridades do contexto nacional em que foi desenvolvida. A linguagem moderna se inseriu no Brasil adaptando-se aos ares de um país tropical e que buscava uma identidade artística, caracterizando-se pelos elementos adotados para amenizar o calor e o excesso de luz ao mesmo tempo em que buscava nas raízes da tradição, um aspecto autoral para a criação de uma arquitetura brasileira. Dessa maneira, ganhava distinção da produção moderna europeia ao evidenciar o esgotamento do racional funcionalismo, que calcado nas possibilidades industriais da produção em série, acabava por afastar a nova produção das peculiares culturas construtivas de cada país.

Sobre as investigações acerca da arquitetura moderna brasileira, a bibliografia que se consolidou se ateve na produção dos grandes centros, especificamente, no eixo Rio de Janeiro - São Paulo. No entanto, as pesquisas que fogem dessa rota têm afirmado a proposição de Giedion ${ }^{1}$ de que encontrava-se no Brasil um certo nível de produção que se mantinha fora das individualidades excepcionais. Mais do que demonstrar que a arquitetura moderna se difundiu em bom nível fora das capitais, essas pesquisas mostramse importantes ao passo que vêm auxiliando a preencher as lacunas da historiografia da arquitetura moderna brasileira.

Dessa forma, objetiva essa dissertação avançar nas pesquisas acerca da difusão da arquitetura moderna brasileira para fora dos grandes centros, descobrindo seus reflexos ante as peculiaridades locais do Triângulo Mineiro e

\footnotetext{
${ }^{1}$ GIEDION, Sigfried. O Brasil e a arquitetura contemporânea. In: MINDLIN, Henrique. Arquitetura Moderna no Brasil. Rio de Janeiro: Aeroplano Editora/IPHAN, 2000, p.17-18.
} 
Alto Paranaíba e identificando, além dos seus protagonistas, os vários mecanismos de apropriação da nova linguagem projetual inserida, que também se refletem na produção de novos valores, novas formas, novos procedimentos técnicos e nos diálogos com a produção dos grandes centros.

Alguns trabalhos importantes já foram publicados acerca da arquitetura moderna na mesorregião, com enfoque maior na cidade de Uberlândia. Dois artigos pioneiros foram os de Laurentiz $^{2}$ e outro em conjunto das arquitetas Patrícia Azevedo e Maria Elisa Guerra ${ }^{3}$, publicados na Revista Projeto, no ano de 1993. O texto de Laurentiz (1993) desenvolve um panorama geral da "arquitetura do cerrado", elencando importantes momentos e personagens na introdução da nova linguagem projetual em Uberlândia. Trabalha a difusão da arquitetura moderna em Uberlândia através dos arquitetos que atuaram na cidade e respectivas formações acadêmicas, sistematizando-os conforme a atuação na cidade: nativos, peregrinos, migrantes, forasteiros, pioneiros, titãs. Tenta também analisar a produção separando-a em gerações, de modo a definir o período de atuação dos arquitetos. O texto de Laurentiz (1993), não se fixa apenas na produção moderna mas vai até uma pequena mostra da produção contemporânea da cidade.

O artigo de Azevedo e Guerra deu continuidade mais tarde nas suas dissertações de mestrado, de 1998, nas quais trabalharam a difusão da arquitetura em Uberlândia através de um arquiteto vetor, o mestre João Jorge Coury, importante introdutor da arquitetura moderna em Uberlândia. Coury realizou também projetos em diversas outras cidades, com um registro volumoso de obras, em sua maioria, de tipologia residencial. O trabalho de Guerra (1998) enfoca a atuação do arquiteto por meio de suas praças na

${ }^{2}$ LAURENTIZ, L. (1993). Olhando as arquiteturas do cerrado. In: Projeto 163, São Paulo, maio, PP. 75-91.

${ }^{3}$ AZEVEDO, P.; GUERRA, M. E. João Jorge Coury, Um Moderno no Triângulo. Projeto, São Paulo, n. ${ }^{\circ} 163, \mathrm{p}$ 78-79, 1993. 
região do Triângulo Mineiro, e o de Azevedo (1998) suas obras residenciais na cidade de Uberlândia. Ambas as dissertações consideram o arquiteto um forte eixo de difusão da arquitetura moderna no estado de Minas Gerais, principalmente na cidade em que se fixou profissionalmente, Uberlândia.

O trabalho de Azevedo (1998), assinala o tema da difusão com um estudo mais aprofundado da formação de Coury, graduado pela Escola de Arquitetura de Belo Horizonte $(\mathrm{EABH})$, atual Escola de Arquitetura da Universidade Federal de Minas Gerais (UFMG). As pesquisas de Azevedo (1998), demonstraram a EABH como um importante eixo de difusão da nova arquitetura em Minas Gerais. Trabalhou profundamente a escola em sua dissertação, citando diversos arquitetos, que formados também pela EABH, seguiram atuando pelo interior de Minas Gerais, em específico, na região do Triângulo Mineiro. A autora ainda desenvolve outras abordagens sobre o tema da difusão, vinculando períodos políticos com a explosão da inserção da linguagem moderna em Uberlândia, em especial, a década de 1950 como um período chave na produção de Coury, relacionando-a com as discussões nacionais que efervesceram nesse período.

Entre 1999 e 2001, foi desenvolvido o projeto de pesquisa "Arquitetura Moderna em Uberlândia - Arquiteto Elifas Lopes Martins", na Faculdade de Arquitetura e Urbanismo da atual FAUeD-UFU, sob coordenação da professora Maria Beatriz Camargo Cappello. Essa pesquisa, que rendeu algumas publicações, objetivava, junto aos trabalhos citados acima, avançar no levantamento da produção moderna em Uberlândia, identificando, catalogando e sistematizando as obras do arquiteto Elifas Lopes Martins na cidade. Além da sua produção arquitetônica, com enfoque residencial e industrial, foram levantados também, dados acerca de sua formação, na Universidade de Brasília (UNB), e dados também da formação da escola de arquitetura da UNB. 
Os trabalhos de Laurentiz (1993), Guerra (1998), Azevedo (1998) e Cappello (1999/2001) são trabalhos pioneiros no estudo a que se pretende, aqui, dar continuidade. Embora, de grande importância, esses trabalhos não fecham o tema, iniciam sim, possibilidades de um avanço para um entendimento melhor e maior da produção moderna nesta mesorregião, podendo ser avançada para as demais cidades que a englobam, que não somente Uberlândia, nos diversos outros processos de apropriação da nova linguagem projetual, e demais importantes arquitetos atuantes nas demais cidades.

Foi com o intuito de dar continuidade aos trabalhos citados acima, que também surgiu o projeto de pesquisa, desenvolvido pelo Núcleo de Pesquisa em Teoria e História da Arquitetura e Urbanismo (NUTHAU), da Faculdade de Arquitetura, Urbanismo e Design da Universidade Federal de Uberlândia (FAUeD-UFU), intitulado "Documentação da Arquitetura Moderna no Triângulo Mineiro e Alto Paranaíba: História e Preservação". O projeto de pesquisa do NUTHAU ancora-se diretamente à pesquisa que resultou nesta dissertação, uma vez que o surgimento das inquietações que fizeram parte do mestrado vieram no período em que a autora desenvolvia sua iniciação científica, no projeto de pesquisa citado acima, durante sua graduação na FAUeD-UFU.

O projeto de pesquisa do NUTHAU, que ainda está em andamento, objetiva identificar e catalogar as obras modernas do Triângulo Mineiro e Alto Paranaíba para constituir um inventário que possa ser divulgado no site ${ }^{4}$ do projeto, e que possa favorecer ações de proteção para algumas obras, buscando promover a conscientização da importância cultural desses edifícios ao passo da grande descaracterização que vêm sofrendo. É também objetivo do núcleo colaborar para que as lacunas da historiografia da arquitetura

\footnotetext{
${ }^{4}$ http://www.arqmoderna.faued.ufu.br/doc_moderno/
} 
moderna brasileira possam ser preenchidas mediante o levantamento e divulgação de novas obras, fora das grandes capitais brasileiras. Nesse trabalho, a catalogação das obras encontradas foi feita por meio de fichas de

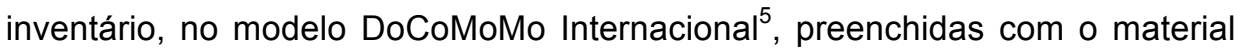
coletado durante as visitas às vinte $\mathrm{e}$ uma ${ }^{6}$ cidades selecionadas pela pesquisa.

O material coletado pelo NUTHAU e as publicações já realizadas a respeito da produção moderna nas cidades do Triângulo Mineiro e Alto Paranaíba foram a base documental que deram suporte às análises e descobertas apresentadas nesta dissertação. É necessário dizer que esse levantamento ainda não corresponde ao total de obras modernas da mesorregião, mas nos dá importantes indícios que permitem já, caracterizar sua produção moderna. Em geral, essa dissertação utiliza do levantamento feito até o ano de 2012.

Desde o princípio do curso de mestrado, optou-se por não fechar o tema em recortes precipitados, deixando que a observação da documentação guiasse esse processo. Esperávamos que não fazer um recorte territorial dentro da mesorregião, isto é, utilizando todo material encontrado nas vinte e uma cidades da pesquisa do NUTHAU, nos desse um olhar mais transversal acerca dessa produção. Da mesma forma, deixamos que esse material nos guiasse no recorte temporal, uma vez que, no material coletado pelo NUTHAU, existiam obras desde meados da década de 1940 até fins da década de 1980 .

\footnotetext{
${ }^{5}$ International Working Party for Documentation and Conservation of Buildings, Sites and Neighbourhoods of Modern Movement - Organização internacional que busca motivar o conhecimento e reflexão sobre o Movimento Moderno, desenvolvendo levantamentos documentais e medidas de conservação e proteção da arquitetura, assim como de conjuntos urbanos e paisagísticos do Movimento Moderno.

${ }^{6}$ Ao todo, 66 (sessenta e seis) municípios formam a mesorregião do Triângulo Mineiro e Alto Paranaíba. Para o início da pesquisa feita pelo NUTHAU-UFU, que está em continuidade, a escolha das 21 (vinte e uma) cidades se deu a partir da tese de doutorado da professora pesquisadora do grupo, Marília M. B. T. Vale, "Arquitetura religiosa do século XIX no antigo Sertão da Farinha Podre", 1998, que tinha como recorte geográfico, essa mesma mesorregião. Com base no seu trabalho de doutorado, a professora indicou as cidades que, pelo seu desenvolvimento econômico, poderiam apresentar uma maior produção moderna em arquitetura.
} 
Pelo volume do material e o pouco espaço que define uma dissertação de mestrado, optamos por inserir na pesquisa somente as obras arquitetônicas, deixando as urbanísticas de lado, uma vez que, também, a dissertação da professora Maria Elisa Guerra constituía, embora não fechasse outras possibilidades, um trabalho substancial sobre o tema. $\mathrm{O}$ recorte temporal também partiu do espaço limitado de um trabalho de mestrado, mas também porque verificou-se a complexidade da década de 1970 na produção arquitetônica do Triângulo Mineiro e Ato Paranaíba, assim como é a do contexto dos grandes centros. Nela, observamos, por vezes, uma continuidade na produção da década de 1980, com contornos singulares e uma diversidade de atitudes e linguagens que beiravam a produção contemporânea da mesorregião. Sendo assim, fechamos o recorte temporal entre a primeira obra moderna conhecida, a Fonte Andrade Junior, de 1945, e aquela em que encontramos o potencial de fechamento e de continuidade das discussões, a Igreja Espírito Santo do Cerrado, de $1975 .{ }^{7}$

Sabíamos que o largo território dessa pesquisa nos dificultaria construir um contexto peculiar sobre uma determinada obra - suas particularidades com o cliente, com o ambiente construído, o entorno, - o que poderia ser conseguido com uma pesquisa pontual, que tornaria a análise mais específica e muito rica. Em todo caso, ainda tentamos envolver esse trabalho em uma análise que extrapolasse o objeto arquitetônico em si, expandindo o campo de discussão sempre que possível, de acordo com a documentação que foi encontrada, onde somam-se também as pesquisas em revistas e jornais da época.

Pela dimensão da documentação com a qual trabalhamos durante a pesquisa de mestrado, elencar os recortes da dissertação foi uma tarefa

\footnotetext{
${ }^{7}$ Datas dos projetos.
} 
demorada. Na qualificação, ocorrida no início de 2013, apresentamos à banca o resultado do processo de sistematização da documentação, que foi elaborado pela autora em meados de 2012. Resultaram dessa sistematização algumas tabelas que foram fundamentais para as discussões feitas durante a banca de qualificação e, depois, para a definição concreta dos recortes do trabalho. Essas tabelas estão anexadas ao final da dissertação e objetivam contribuir na eleição de outras futuras abordagens que o tema da difusão da arquitetura moderna no Triângulo Mineiro e Alto Paranaíba possibilita.

Cabe ainda dizer aqui que a delimitação territorial da mesorregião do Triângulo Mineiro e Alto Paranaíba é recente, e data de um momento que é ainda posterior ao do recorte temporal desse trabalho. Nesse sentido, permitimos tratar nossa região dentro de um "território histórico", isto é, que não fosse determinado por um limite territorial específico mas que valesse das diversas documentações encontradas acerca do Sertão da Farinha Podre, posteriormente conhecido como Triângulo Mineiro. Nos apropriamos, nesse sentido, consentindo por vezes chamar nossa mesorregião apenas como "Triângulo" ou "Triângulo Mineiro", com a ressalva de que nossas vinte e uma cidades pertencem ao território mineiro oficializado como Triângulo Mineiro e Alto Paranaíba na década de 1990.

Sendo assim, esse trabalho foi dividido em três capítulos.

O primeiro capítulo, intitulado "O Triângulo Mineiro e Alto Paranaíba: Elementos de Contexto" objetiva contextualizar o Triângulo Mineiro e Alto Paranaíba, no âmbito sócio-político-cultural, abordando os elementos de contexto que formam o quadro onde a arquitetura moderna se produziu. Devido a dificuldade de focar nas diversas maneiras em que cada uma das vinte e uma cidades da pesquisa se desenvolveram, este capítulo foi elaborado de modo que cobrisse um quadro regional, evitando peculiaridades de uma ou outra 
cidade, e tentando transparecer os pontos que elegemos como importantes para a análise geral da documentação.

O segundo capítulo, intitulado "Os Primeiros Passos para a Produção de uma Arquitetura Moderna" buscou narrar as primeiras manifestações da arquitetura moderna encontradas no Triângulo Mineiro e Alto Paranaíba, expondo seus protagonismos e demonstrando que essa nova produção se inseria em um contexto cujo um ideário moderno vinha sendo formado, em diversos âmbitos da história regional. Foram eleitos três eventos importantes nesse primeiro processo de meados da década de 1940 à década de 1950: a construção da Fonte Andrade Junior no Conjunto Paisagístico para o Parque da Estância do Barreiro de Araxá, do arquiteto Francisco Bolonha; a construção das Instalações Industriais da Fertiza, também em Araxá, do arquiteto Raphael Hardy Filho; e a atuação dos arquitetos residentes.

O terceiro capítulo, intitulado "Arquitetura Moderna no Triângulo Mineiro e Alto Paranaíba Pós-60" procurou abordar a produção arquitetônica moderna da região após a construção de Brasília, visto que a mudança da capital para o Planalto Central é parte do processo de desenvolvimento do Triângulo, demonstrando-se também um fator importante para o avanço da produção moderna em questão. O capítulo foi estruturado elegendo momentos importantes da arquitetura moderna regional, partindo de Brasília, como a construção da Estação Ferroviária de Oswaldo Arthur Bratke em Uberlândia, o processo de verticalização nos anos de 1960, a construção da Vila de Operadores de Jaguara na pequena cidade de Sacramento e o projeto de Lina Bo Bardi para a Igreja Espírito Santo do Cerrado, em Uberlândia.

Espera-se que essa leitura acerca da arquitetura moderna produzida no Triângulo Mineiro e Alto Paranaíba dê continuidade em novas discussões, instigue novos trabalhos e a procura de novos elementos, colocando em pauta 
a arquitetura moderna do interior brasileiro, auxiliando dessa maneira, não somente a preencher as lacunas da historiografia da arquitetura brasileira, como colocando em pauta a necessidade e os mecanismos de sua preservação. 
Arquitetura Moderna no Triângulo Mineiro e Alto Paranaíba: indícios para a construção de uma cultura arquitetônica (1945-1975) 


\section{Capítulo 1}

O TRIÂNGULO MINEIRO E ALTO PARANAÍBA: ELEMENTOS DE CONTEXTO 

Tratar um tema com um recorte territorial tão extenso, nos exigiu usar de algumas estratégias. Estamos falando de vinte e uma cidades ${ }^{1}$, um contexto regional, mas que embora isso, tem suas particularidades inseridas em cada município. Culturalmente, o Triângulo Mineiro apresenta certa homogeneidade, mas certamente o estudo do desenvolvimento político e econômico de cada município revelaria contextos únicos, embora estamos certos que estes também dialogariam com os contextos arredores. Abordar, inicialmente, nesse trabalho, um quadro sócio-político-econômico regional exigiu a tomada de uma estratégica generalizadora, que desse conta do tamanho limitado de uma pesquisa de mestrado e que conseguisse ser oportuno na discussão do tema central da pesquisa: arquitetura moderna no Triângulo Mineiro e Alto Paranaíba.

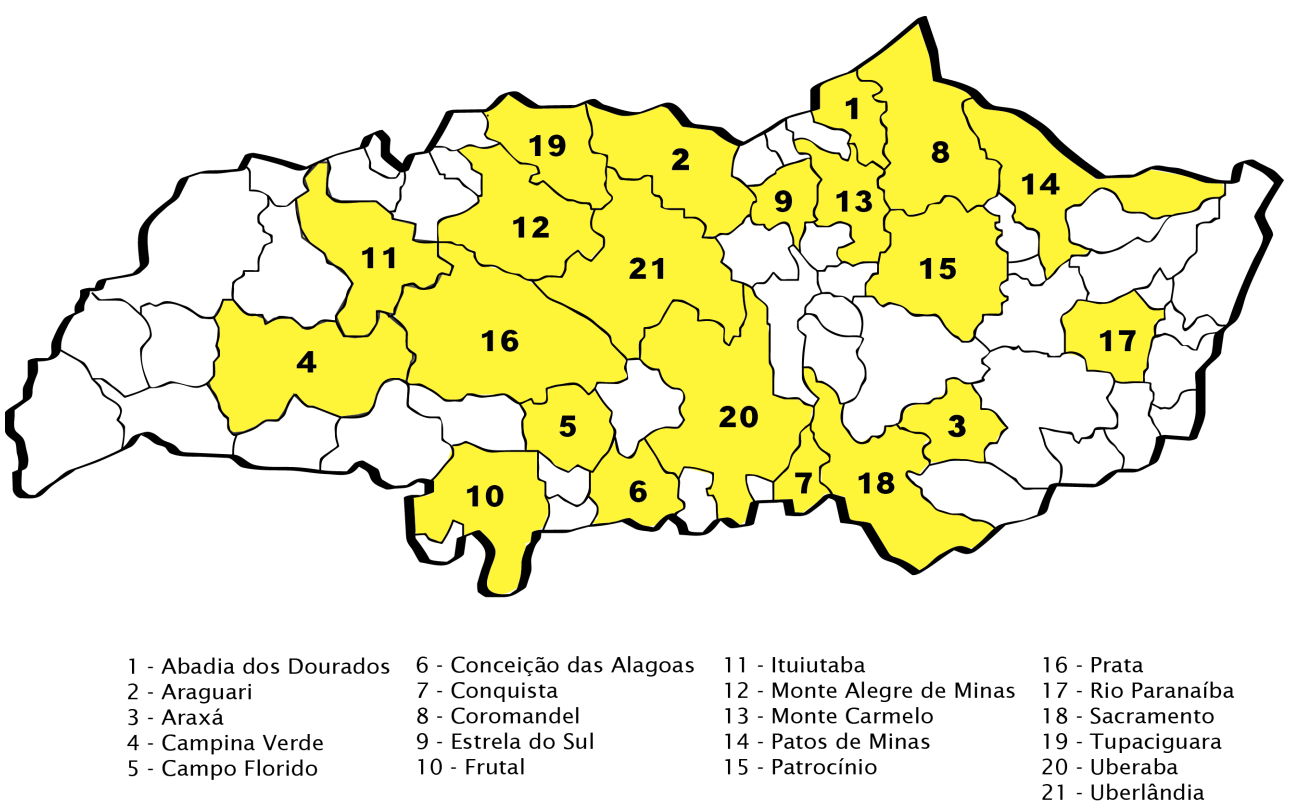

1. Mesorregião do Triângulo Mineiro e Alto Paranaíba. Em amarelo, as 21 cidades escolhidas para pesquisa. Fonte: Elaborado pela autora.

\footnotetext{
${ }^{1}$ Ao todo, 66 (sessenta e seis) municípios formam a mesorregião do Triângulo Mineiro e Alto Paranaíba. Para o início da pesquisa feita pelo NUTHAU-UFU, que está em continuidade, a escolha das 21 (vinte e uma) cidades se deu a partir da tese de doutorado da professora pesquisadora do grupo, Marília M. B. T. Vale, "Arquitetura religiosa do século XIX no antigo Sertão da Farinha Podre", 1998, que tinha como recorte geográfico, essa mesma mesorregião. Com base no seu trabalho de doutorado, a professora indicou as cidades que, pelo seu desenvolvimento econômico, poderiam apresentar uma maior produção moderna em arquitetura.
} 
Ao eleger trabalhar os aspectos regionais gerais para os âmbitos político e econômico do Triângulo, conseguimos encontrar um quadro regional que nos possibilitou dialogar o quadro observado e as interlocuções com a arquitetura moderna produzida, ainda que, como era de se esperar, o quadro acabasse por focar nas cidades maiores. Enxergamos nele, um conjunto de operações que nos fez entender melhor como foi possível a construção de uma cultura arquitetônica moderna no Triângulo Mineiro e Alto Paranaíba.

Partimos de uma pesquisa bibliográfica dos estudos feitos para a região, dissertações e teses, que foram sendo complementadas a partir dos pontos chaves descobertos para nosso tema central, que fomos encontrando ao longo das leituras. Somamos à estas, a documentação encontrada em jornais e revistas, em pesquisas feitas em campo, nas cidades maiores. Posto isto, o primeiro capítulo foi dividido de modo a transparecer os pontos dessa historiografia regional que elegemos como importantes no diálogo com a produção da arquitetura moderna na região. Assim, essa divisão não é cronológica, deixa em segundo plano a linha do tempo linear para sobressair os momentos desse quadro que julgamos terem sido importantes para a construção de uma cultura moderna, nas edificações e no imaginário local.

Veremos nesse primeiro capítulo, que o desenvolvimento da região é muito ligado à uma estratégia geopolítica, onde o Triângulo Mineiro era favorecido por sua localização central, rota de ligação rumo ao oeste. Essa característica rendeu ao Triângulo conexões importantes com a economia paulista, embates de hegemonia entre as cidades, um imaginário que envolve um entendimento de modernidade ligado ao rápido desenvolvimento da região, um ideal de cidade conforme os interesses de uma classe dirigente, atrelada em vários momentos ao setor da construção civil. 


\section{Características Territoriais e Geográficas}

Embora a região desse estudo fosse conhecida regularmente como Triângulo Mineiro pelo formato territorial triangular delimitado no mapa de Minas, foi somente em 1973 que o Instituto Brasileiro de Geografia e Estatística (IBGE) e a Fundação João Pinheiro (FJP), denominou como Triângulo Mineiro e Alto Paranaíba a grande região a extremo oeste do estado de Minas Gerais. A divisão territorial do estado em "Regiões Funcionais Urbanas" havia sido concluída um ano antes, em 1972, a qual dividia o território brasileiro em microrregiões homogêneas para fins de planejamento. Esse processo de regionalização do estado terminou somente na década de 1990, com a divisão do território mineiro pelo IBGE em doze mesorregiões geográficas e por conseguinte em sessenta e seis microrregiões geográficas com características territoriais e de produção mais específicas, onde a nossa mesorregião teve seu território sensivelmente expandido no Alto Paranaíba. (DINIZ; BATELLA, 2005)

Grande parte do Triângulo Mineiro e Alto Paranaíba já aparecia delimitada nos documentos oficiais do Tratado de Tordesilhas, no século XVII, onde, pela linha de tordesilhas, parte da região aparecia como pertencente à Espanha. Seu território pouco conhecido até o século XVI era ocupado por populações indígenas, Caiapós, Paranás, Bororós, Chicriabás, e Araxás. O Triângulo somente passou a pertencer oficialmente ao estado de Minas Gerais em 1816. Fora território de Goiás desde 1744 e antes disso, pertenceu ao estado de São Paulo. (BRANDÃO, 1989) Voltaremos à essa questão de disputa territorial ainda nesse capítulo, quando discutiremos o imaginário da população diante de um sentimento político-cultural de não pertencimento ao estado de Minas Gerais. 


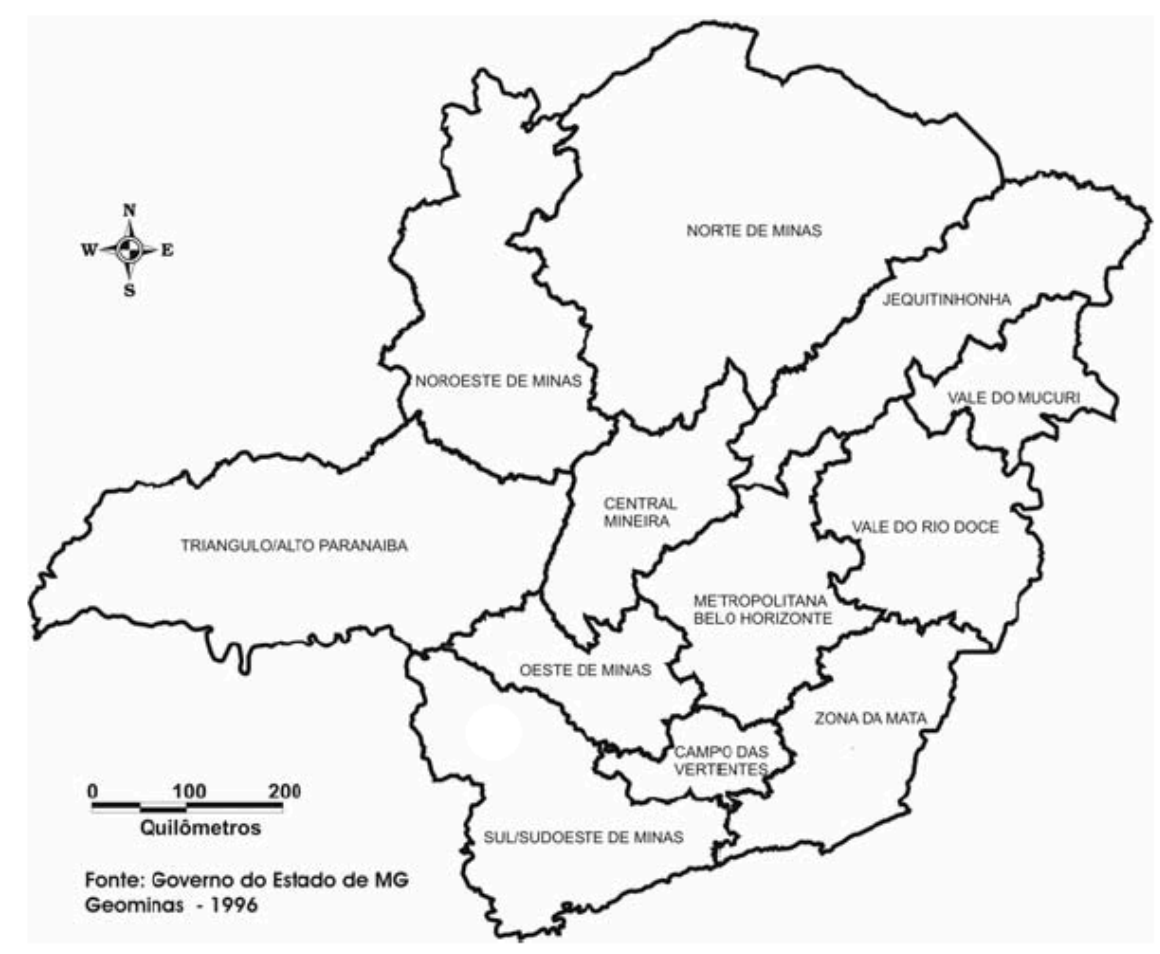

2. Microrregiões Geográficas de Minas Gerais segundo o IBGE - 1990. Fonte: DINIZ; BATELLA, 2005.

O formato triangular característico da região do Triângulo Mineiro, somada a região do Alto Paranaíba, é delimitado pelas bacias hidrográficas do Rio Grande, ao sul, e do Rio Paranaíba, ao norte, as quais se encontram formando a ponta do formato triangular dos limites da mesorregião. O Rio Paranaíba, com nascente na serra da Mata da Corda, município de Paranaíba e fluxo descendente pelo território triangulino, desemboca no Rio Grande, onde ambos passam a formar o Rio Paraná. A grosso modo, a região limita-se a oeste pela confluência dos rios Grande e Paranaíba, e a leste pela Serra da Canastra e Marcela. 


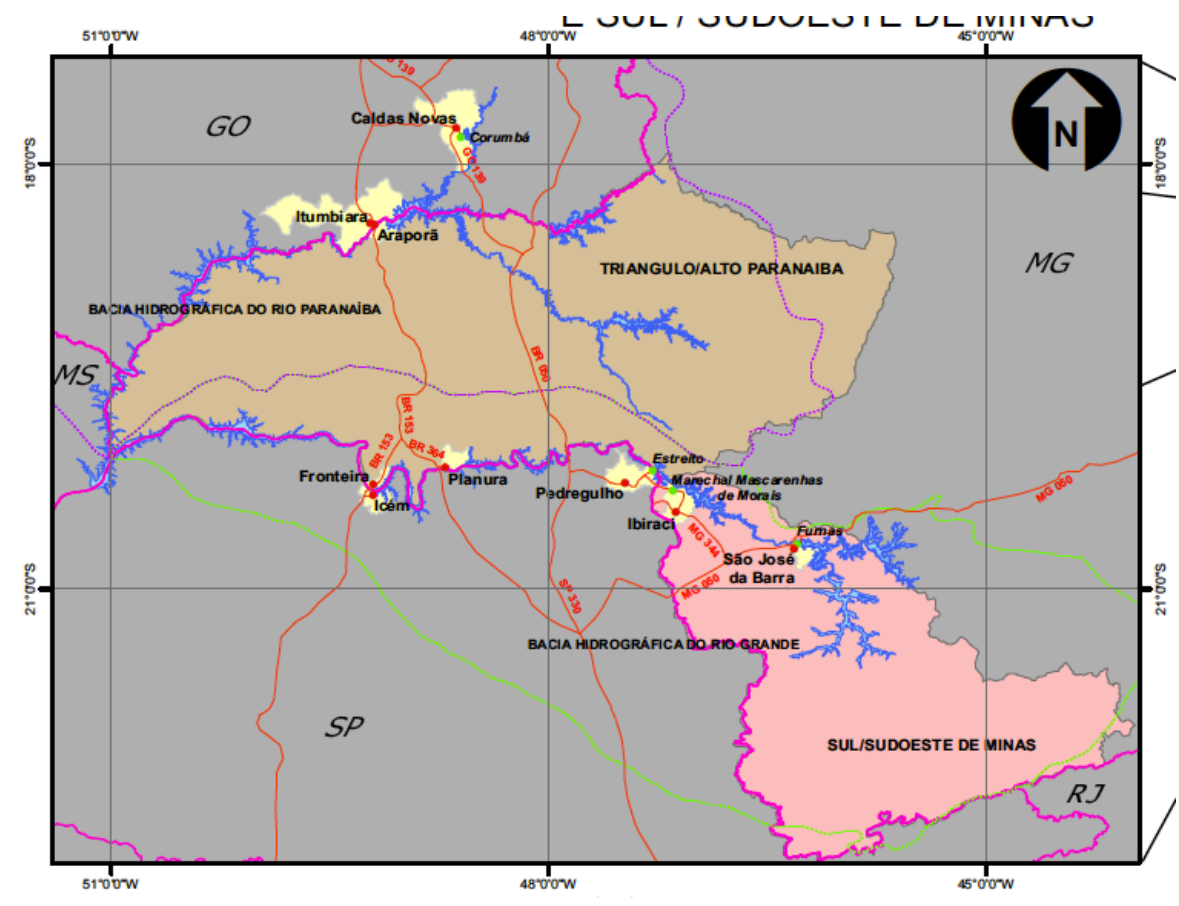

3. Em rosa, as bacias hidrográficas do Triângulo Mineiro e Alto Paranaíba. Fonte: GUERRA, 2008.

O quadro natural da mesorregião não pode ser negligenciado na busca do entendimento do seu processo de desenvolvimento. Assim como todo o estado de Minas Gerais, o Triângulo Mineiro encontra-se em uma complexa zona de transição natural, apesar de uma certa uniformidade de sua estrutura geológica. Possui um perfil bastante diversificado, predominante de chapadões recobertos por vegetação típica do cerrado, mas composto também de campos, areões, cascalhos, etc. A sua topografia apresenta patamares elevados chegando a $1000 \mathrm{~m}$ de altitude ao norte e terras mais baixas ao sul, em torno de $500 \mathrm{~m}$ de altitude. O potencial hidrográfico da região, assim como o clima ameno, favoreceu o surgimento de solos férteis para agricultura ao longo das encostas e dos vales próximos à Bacia do Paraná, onde se desenvolveram também áreas de pastagens destinadas à engorda do gado bovino. Os diversos rios da região, pertencentes às bacias do Rio Grande e Paranaíba, fizeram com que o Triângulo fosse alcunhado de "Mesopotâmia Brasileira". (FREITAS; 
SAMPAIO, 1985) Mais tarde, a partir da década de 1960, o uso do potencial energético dessas bacias deixará grandes transformações na paisagem da região, como analisa Guerra (2008), e cujo tema retornaremos ao analisar a Vila de Operadores de Jaguara, no terceiro capítulo.

A mesorregião do Triângulo Mineiro e Alto Paranaíba é formada por sessenta e seis municípios agrupados em sete microrregiões: Araxá, Frutal, Ituiutaba, Patos de Minas, Patrocínio, Uberaba e Uberlândia. Apesar de ser a terceira mesorregião mais populosa do estado, concentra a maior parte da população em quatro municípios, segundo estimativas do IBGE 2012: Uberlândia com 619.536 habitantes, Uberaba com 302.623 habitantes, Patos de Minas com 140.950 habitantes, e Araguari com 110.983 habitantes. A mesorregião faz fronteira com os estados de Goiás, São Paulo e Mato Grosso do Sul, interligando também com a Central Mineira e com o Oeste de Minas, sendo a característica de "rota de passagem" o principal fator do desenvolvimento de sua economia. 


\section{O Triângulo no Processo de Interiorização do Brasil e o Início das Relações com São Paulo}

Se existe o que poderíamos chamar de uma cultura de desenvolvimento do Triângulo Mineiro e Alto Paranaíba, esta é diretamente ligada ao conjunto de operações, estratégias e diálogos da região com seus estados de divisa, a saber de sua localização privilegiada. Para Brandão (1989), "a inserção do Triângulo numa divisão inter-regional do trabalho não é mais do que um estreitamento maior das históricas ligações da região com os seus estados vizinhos: São Paulo, Goiás e Mato Grosso." Isso significa que entender a construção dessa cultura desenvolvimentista, que incidirá sobre a produção arquitetônica da região, é entender ao mesmo tempo o modo e os desdobramentos das relações que permeiam os diálogos da nossa região com seus arredores, sobretudo com São Paulo.

O trabalho de Brandão (1989) - cuja referência está por todo esse capítulo e em outros trabalhos que tem como recorte territorial a mesma região - nos apresenta a afirmação em que descreve o Triângulo Mineiro como "fruto da ambiguidade de seu estigma de fazer parte de Minas, mas ser articulado economicamente a São Paulo." De fato, ao construir o enredo que leva a região à sua inserção na dinâmica econômica nacional, vemos que este se liga menos ao estado de Minas Gerais do que aos estados de Goiás, e principalmente São Paulo, onde nos cabe lembrar as distâncias quase equivalentes entre o Triângulo e a capital mineira, e entre o Triângulo e a capital paulista. São nos acordos econômicos e nos diálogos com a capital paulista que o Triângulo avança na estruturação de seus sistema de transportes - iniciado pelos uso dos fluxos fluviais, ferroviários e depois ao ápice, com as rodovias - sistema que será essencial na mediação comercial da capital paulista com o centro-oeste brasileiro. 
Como rota de passagem, o desenvolvimento do Triângulo teve a "singularidade marcada pelo cumprimento, desde a ocupação, de uma função abastecedora de uma vasta área" (BRANDÃO,1989), destacada mais tarde com a construção de Goiânia em meados dos anos de 1930, e Brasília, no final da década de 1950, conjuntamente com a evolução de seu sistema de transportes. Tendo Uberlândia como referência, por via terrestre, Belo Horizonte está a $550 \mathrm{~km}$ da cidade, Brasília a $430 \mathrm{~km}$, Goiânia a $350 \mathrm{~km}$ e São Paulo a $590 \mathrm{~km}$. Esses números nos indicam a importante característica para o processo do desenvolvimento do Triângulo Mineiro, atrelado ao próprio desenvolvimento nacional: o fato de que a região não só se insere no centro do território brasileiro, mas está no meio do caminho rumo ao oeste.

Grande parte da região que delimitamos hoje como Triângulo Mineiro e Alto Paranaíba tornou-se conhecida ao final do século $\mathrm{XVI}$ através das "Bandeiras", expedições saídas de São Paulo em direção à Goiás que se beneficiavam da vegetação rarefeita do cerrado à propósito da penetração ou do processo de autocolonização do chamado Brasil Central. Durante os séculos XVI, XVII e VXIII, o Triângulo se transformou em uma área de abastecimento de mineiradores de Goiás e Mato Grosso, ficando conhecido como "Sertão da Farinha Podre". Sua economia era marcada pela comercialização para o sudeste de índios comercializados ou catequizados pelos missionários da Companhia de Jesus, a exploração de metais preciosos, a ocupação e interiorização de povoamentos através das "picadas" pelo interior do cerrado ou através da navegação dos diversos rios da região. Esse processo de interiorização ocasionou uma corrente migratória no sentido leste/sertões, e mais tarde, no século XVIII, o extermínio indígena aliado ao esgotamento das minas fixou alguns migrantes, dando origem a algumas povoações baseadas na economia de subsistência e criação de gado, como as cidades de Desemboque, Araxá e Uberaba. 
A ocupação do território triangulino no século XIX seguiu dando origem às vilas, muitas a partir de concessões de Sesmarias, como é o caso de Uberlândia. No final do século, as cidades de Araxá e Uberaba exerceram um importante papel no abastecimento das tropas brasileiras durante a Guerra do Paraguai (1864/1870), o que, conjuntamente com a expansão agrícola para o oeste paulista - que era predominante de plantações de café com uso de mãode-obra imigrante - fez com que surgisse uma demanda de outros gêneros alimentícios, fazendo com que o Triângulo Mineiro respondesse como um forte fornecedor. (GUERRA, 1998)

Nas primeiras décadas do século $X X$, grande parte das cidades do Triângulo já contavam com rede de energia elétrica, transportes, telefonia e telégrafos. Guerra (1998) reforça o fato de que, com exceção dos correios e telégrafos, todos os demais sistemas contavam com recursos privados, o que reforçava a circulação mercantil e a especialização da produção econômica de algumas cidades, como foi o caso de Uberlândia, que passou a se firmar comercialmente na região a partir da estruturação de uma vasta rede de estradas de rodagem, cujo assunto retornaremos a pouco.

Na primeira metade do século XX, a diversificação da produção regional vai se beneficiar novamente de sua posição estratégica, agora, diante do discurso oficial de integração nacional e deslocamento de fronteiras defendidas a partir dos anos 30, com o presidente Getúlio Vargas. A retomada do lema bandeirante da marcha para o oeste fez com que o Triângulo, diante do papel que desempenhou no incentivo ao progresso e ocupação do centro-oeste brasileiro, recebesse a alcunha de "nariz de Getúlio".

O Triângulo vai se beneficiando, diversificando sua produção regional, quando a partir dos anos 30 o discurso oficial da integração nacional e deslocamento de fronteira, defendidas pelo 
presidente Getúlio Vargas, vai ser incrementada, com a busca da estruturação de núcleos básicos; não apenas na faixa litorânea, mas abrangendo a totalidade do país visando a retomada do "lema bandeirante da marcha para o Oeste". (GUERRA, 1998)

Para Brandão (1989), ao "investigar a peculiar dinâmica da economia do Triângulo, em razão de sua posição geográfica de entroncamento de diversos fluxos", a discussão da chamada "Marcha para o Oeste" é substantiva. O interesse da região na incorporação do oeste ao mercado nacional deu grande dinamismo à produção econômica do Triângulo Mineiro durante a primeira metade do século XX. A fundação de Goiânia, em 1933, foi ainda, segundo o autor, uma estratégia política importantíssima nesse processo, onde os comerciantes triangulinos, a princípio, ganharam muito com a fundação da nova capital.

No que diz respeito ao processo de autocolonização do Brasil Central, Goiânia foi a legítima experiência urbana na definição de um pólo regional ou como elemento central para o desenvolvimento e integração do Centro-Oeste brasileiro ao Brasil, no período varguista. $\mathrm{Na}$ qualidade de seu quadrante geográfico, a cidade foi capaz de atuar na dinâmica do desenvolvimento nacional, exercendo papel central na expansão das fronteiras produtivas rumo ao oeste, tornando-se um centro urbano essencial no avanço de outros centros econômicos do cerrado, como a região do Triângulo Mineiro e Alto Paranaíba.

Com Goiânia, fulcro urbano capaz de polarizar o processo de ocupação territorial que apenas se esboçava, Goiás participa da autocolonização do Brasil Central, contribuindo com significativo crescimento demográfico à região. A cidade foi capaz de atuar na dinâmica do desenvolvimento nacional. Como cidade-capital, planejada e "moderna", construída na parte mais desenvolvida e povoada do Estado (região sul/sudeste), foi central no processo de 
expansão das fronteiras produtivas rumo ao oeste pelas frentes pioneiras que colonizavam terras até então sem ocupação e exploração efetivas. (MOTA, 2004)

Brandão (1989) expõe que, posteriormente, embora Goiânia tivesse exercido um papel significativo para a diversificação da produção triangulina, esta foi perdendo sua hegemonia sobre o mercado goiano, na medida em que Anápolis e a nova capital Goiânia consolidavam-se como centros comerciais urbanos para onde convergia a produção regional. O autor salienta a perda do dinamismo comercial da região mineira no fim dos anos 40 e 50, onde o capital comercial, que antes sediava, perdia espaço na medida em que a fronteira do centro-oeste ia se "fechando".

Nesse momento, em meados do século $X X$, o Triângulo Mineiro já se inseria na dinâmica do mercado nacional. Primeiro, e sobretudo, por sua posição estratégica: historicamente, as cidades da região caracterizavam-se pelo papel de "pontos de passagem", sendo esse o fator principal na transformação de seus centros urbanos, pontos de intersecção de mercadorias; segundo, pela base privilegiada de recursos naturais disponíveis. Seu solo, clima, topografia, minérios, recursos hidrográficos, vegetação, etc., potenciaram gradualmente as vantagens dentro da qualidade de sua localização; terceiro, pela "ausência de resistências culturais enraizadas"² que poderiam obstar as relações capitalistas de produção. As relações econômicas do Triângulo Mineiro, historicamente foram mais estreitas com São Paulo do que com o próprio restante de Minas, situação que é fruto não somente do histórico de pertencimento da região pelos seus estados de divisa, como vimos no início desse capítulo, mas pelo sentimento cosmopolita que contornava os interesses de sua população; quarto, pela não necessidade de um mercado de trabalho

\footnotetext{
${ }^{2}$ Os cinco pontos apresentados foram retirados do trabalho de Brandão (1989). O autor sintetiza os fatores que inseriram a região na divisão Divisão Inter-Regional do Trabalho.
} 
regional, visto que a mão de obra requisitada para essa tarefa poderia ser, em grande medida, familiar; e por último, o Triângulo Mineiro conseguira inserir-se na dinâmica econômica nacional pela fundamental infra-estrutura das redes de transportes, onde as estradas de rodagem viriam complementar os fluxos comerciais já efetuados pelas estradas de ferro.

Era, segundo Brandão (1989), a precariedade dos transportes o empecilho à tendência clara à integração dos mercados regionais com São Paulo, "núcleo hegemônico da acumulação de capital no país". O território que abrangia o sul e sudeste goiano e ainda parte do Mato Grosso se tornara comercialmente dependente do entreposto em que se constituíram as cidades de Araguari, Uberaba e Uberlândia, principais centros triangulinos. "A colocação desses produtos no mercado paulista estava subordinada à intermediação exercida pelo Triângulo", e a chegada das estradas de ferro da Cia Mogiana asseguraria a acessibilidade dos produtos agrícolas e agropecuários do Brasil Central à São Paulo. E o Triângulo Mineiro tinha "todas as condições para, utilizando sua herança histórica de 'ponto de passagem', tornar-se 'ponto de intersecção' de um dos mais importantes circuitos mercantis do país [...]." (BRANDÃO, 1989, p. 42) 


\section{A Implantação das Ferrovias, Estradas de Rodagem e a Dinâmica entre as Cidades}

Antes de iniciar essa parte do capítulo, cabe dizer que, como lembra Guerra (1998) e, Mesquita e Silva (2006), uma conjunção de fatores que incluem os serviços de transportes intermunicipais, fazem parte da evolução econômica do Triângulo Mineiro e Alto Paranaíba. No entanto, consideramos a implantação da Companhia de Estradas de Ferro Mogiana na região, em fins do século $\mathrm{XIX}$, o mais importante agente na intensificação da característica do território como ligação entre importantes núcleos comerciais e de produção do sudeste e do interior centro-oeste do país. Mais do que isso, separar nesse capítulo um espaço para investigar o processo de desenvolvimento dos sistemas de transportes na região significa que a questão incide em fatores essenciais ao tema central desse trabalho - arquitetura moderna no Triângulo Mineiro e Alto Paranaíba - a saber: a dinâmica populacional das cidades; os embates que giram em torno da formação e a alternância dos pólos regionais do Triângulo; o estreitamento gradual das relações com São Paulo, que já iniciamos a abordagem nas linhas anteriores; e a construção de um imaginário e representação de uma cultura, estes últimos os quais seguiremos nas sessões seguintes.

O quadro populacional do Sertão da Farinha Podre, em finais do século XIX, nos aponta as maiores cidades: Araxá com 10.584 habitantes, Sacramento com 9.893 habitantes e Uberaba com 8.790 habitantes. ${ }^{3}$ Muito embora, Araxá figurasse como cidade mais populosa, área de pecuária muito ativa, agricultura e exportação de tecidos, era a cidade de Uberaba que tomava o papel de pólo regional ou cidade primaz do Triângulo Mineiro. Isso porque, dados

\footnotetext{
${ }^{3}$ Esse quadro populacional mostra que, nesse período, a densidade demográfica da região seguia o processo de interiorização do Brasil, isto é, a área do Triângulo mais a oeste, conhecida como Pontal do Triângulo - o baixo curso dos rios Paranaíba e Grande - ainda era um vazio demográfico. As densidades demográficas diminuiam em direção à oeste.
} 
populacionais absolutos ou relativos tendem a inferir economias mais ativas, porém, como descreve Lourenço (2007), não revelam a centralidade de um lugar. O que assegurava a primazia de Uberaba como cidade pólo do Triângulo era essencialmente a sua localização na região, onde se pode fazer um paralelo acerca do desenvolvimento e importância dessa cidade para a região com o próprio desenvolvimento e importância do Triângulo para a economia nacional: "Uberaba era um nó de um sistema radial de estradas, o entreposto obrigatório de todos os fluxos mercantis de norte e oeste, dos territórios de Goiás e Mato Grosso." (LOURENÇO, 2007, p. 136)

\begin{tabular}{|l|c|c|}
\hline \multicolumn{1}{|c|}{ Freguesia } & População & $\begin{array}{c}\text { Densidade demográfica } \\
\text { (hab/1000 km2) }\end{array}$ \\
\hline Uberaba & 8.710 & 1,13 \\
\hline Uberabinha & 3.480 & 1,64 \\
\hline Frutal & 4.487 & 0,78 \\
\hline Sacramento & 9.893 & 2,23 \\
Forquilha & 8.220 & 5,98 \\
\hline Desemboque & 2.260 & 1,48 \\
\hline S. José do Tejuco & 2.131 & 0,22 \\
\hline Prata & 2.886 & 0,59 \\
\hline Campo Belo & 1.319 & 0,36 \\
\hline S. Francisco Sales & 2.132 & 0,30 \\
\hline Monte Alegre & 3.296 & 1,13 \\
\hline Abadia do Bom Sucesso & 3.380 & 1,59 \\
\hline Santa Maria & 1.943 & 0,97 \\
\hline Bagagem & 7.356 & 5,33 \\
Brejo Alegre & 4.480 & 1,26 \\
\hline Carmo da Bagagem & 4.927 & 2,43 \\
\hline Agua Suja & 3.449 & 8,58 \\
\hline Araxá & 10.584 & 9,08 \\
\hline Pratinha & 2.346 & 1,75 \\
\hline Campo Grande & 2.729 & 5,19 \\
\hline Carmo do Arraial Novo & 3.540 & 2,71 \\
\hline
\end{tabular}

4. População do Sertão da Farinha Podre, por freguesia, em 1872. Fonte: LOURENÇO, 2007.

Nos descreve Lourenço (2007) que, como cidade que irradiava os fluxos mercantis do Triângulo, e manipulava as condições do mercado a montante, Uberaba se favorecia da extração de grande parte dos excedentes gerados, de tal sorte que conseguia centralizar também atividades como 
atendimento médico, educação, acesso à justiça e administração pública. A figura 5, como representação da qualidade da situação geográfica da cidade, representa bem este atributo de entroncamento de fluxos. Nessa delimitação territorial do Sertão da Farinha Podre de finais do século XIX, Uberaba situa-se ao sul da região, quase à linha de fronteira com São Paulo, o que alguns autores denominam de "ponta linha" ou "boca do sertão", ou seja, o início da linha de estradas do Triângulo até o centro-oeste do país, onde mais tarde, com a implantação da ferrovia, Araguari se beneficiaria como ponta de linha ao norte do Triângulo, fazendo o fluxo de comercialização no sentido Goiás - São Paulo. A Estrada de Goiases, a Estrada Real / Geral e a Estrada do Piquiri eram as principais rotas terrestres da Farinha Podre antes da chegada da ferrovia.

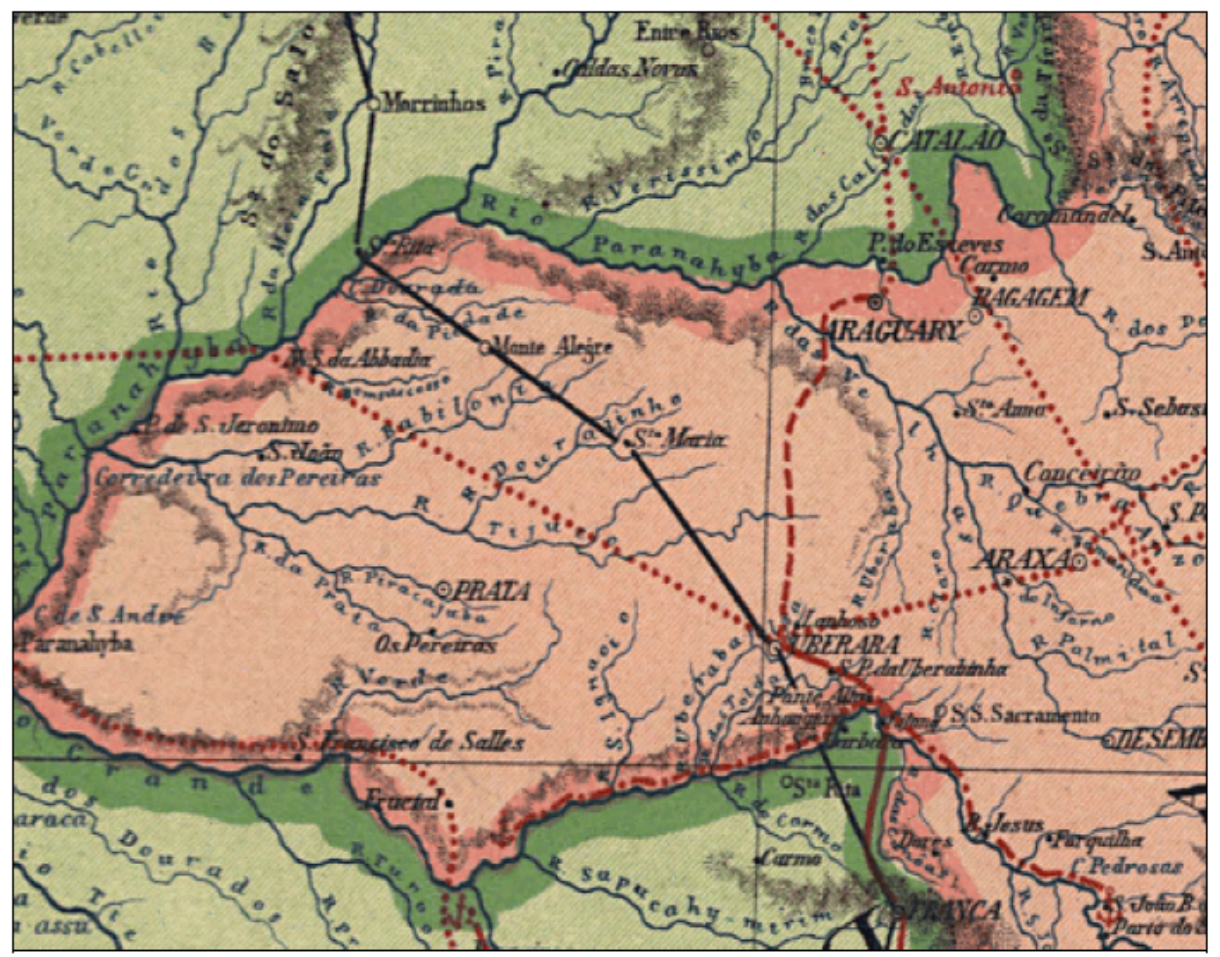

5. Triângulo Mineiro, final do século XIX. A cidade de Uberaba como entroncamento de fluxos. Fonte: PENHA, 1892 apud LOURENÇO, 2007. 
Uberaba convertera-se em um nó de uma rede de estradas que se irradiavam para várias direções entre os rumos norte e oeste. Essas estradas penetravam os sertões, escassamente povoados, da Farinha Podre, Mato Grosso e Goiás. Por meio delas fazia-se o abastecimento dos gêneros não produzidos nesses lugares, e eram drenados esses produtos dessas áreas. Negociantes de Uberaba, dessa maneira, retinham e acumulavam parte dos excedentes ali gerados. (LOURENÇO, 2007, p.129)

A chegada da ferrovia no final do século XIX foi o principal elemento no primeiro contexto de embates entre cidades do Triângulo pela supremacia do escoamento de mercadorias pela rota ferroviária São Paulo - Goiás e Goiás São Paulo. Com a implantação das estradas de ferro da Mogiana, em 1888, e sua extensão até Araguari, em 1896, Uberaba passou a dividir a centralidade da região com Araguari que passou a figurar-se como "ponta-linha" na rota de comercialização de mercadorias do Brasil Central até a capital paulista. ${ }^{4}$ Essa quebra do pólo regional do Triângulo expressa transformações importantes, consequentes da criação da ferrovia no Triângulo Mineiro. Segundo Brandão (1989), Araguari se beneficiou do fato de ser "ponta de linha" da Estrada de Ferro Mogiana durante um longo período. Detinha praticamente monopólio do fluxo de comercialização no sentido Goiás - São Paulo, o que Ihe assegurava também a capacidade de reter grande parte do excedente goiano.

A partir de então, Araguari foi "capturada" pela região. Ligada economicamente a Bagagem e Araxá até a década de 1880, por razões históricas e pela centralidade exercida por aquelas duas cidades, aproximou-se de Uberaba e da província de São Paulo, graças aos trilhos da Mogiana. [...] Uberaba concentrava funções centrais em volume suficiente para manter-se como núcleo

\footnotetext{
${ }^{4}$ Lourenço (2007, p. 141) sublinha que "antes mesmo da chegada da ferrovia, dois acréscimos viários contribuíram para distribuir a centralidade, até então concentrada em Uberaba, para outras cidades: o Porto do Frutal e a Ponte do Jaguara."
} 
influente, embora não mais em situação de primazia. (LOURENÇO, 2007, p.153)

A Companhia Mogiana de Estradas de Ferro foi criada em 1872 por fazendeiros de Campinas e tinha como plano inicial estender-se até a região cafeicultora de Ribeirão Preto e às margens do Rio Grande. Tal propósito sofreria certo atraso visto que a Companhia Paulista de Estradas de Ferro entendia naquela época que Ribeirão Preto se encontrava dentro de sua zona de privilégio. A resistência da Paulista se prolongou até 1880 , quando a companhia abandonou seus projetos para o novo oeste paulista e a Mogiana conseguiu avançar suas estradas rumo ao norte, atingindo Ribeirão Preto em 1883, Franca em 1887 e as margens do Rio Grande em 1888. (MATOS, 1990 apud LOURENÇO, 2007) A Paulista e a Mogiana expandiram ramais para diversas cidades paulistas. No Triângulo, a Mogiana deu continuidade ao Ramal Catalão, levando a estrada até as proximidades do Rio Paranaíba. As cidades da Farinha Podre cruzadas pela ferrovia eram Uberaba, com estação inaugurada em 1889, Uberabinha (atual Uberlândia), inaugurada em 1895 e Araguari, em $1896 .^{5}$

Sabe-se, como sublinha Lourenço (2007, p. 145), que "as pressões particulares dos fazendeiros pelo acesso às linhas foram fatores importantes na determinação do traçado das estradas", mas sobretudo, como já comprovara previamente Brandão (1889), a principal estratégia da Mogiana ao adentrar o Triângulo estava em explorar as possibilidades de abstecimento pelo capital cafeeiro, a partir do oeste mineiro e paulista. ${ }^{6} \mathrm{E}$ tal como Brandão, Lourenço (2007, p. 145) mais tarde deduziria que "a expansão ferroviária pelo Triângulo

\footnotetext{
${ }^{5}$ Ver mais em Lourenço (2007), onde o autor discorre acerca da formação do trajeto da Mogiana no Triângulo Mineiro.

${ }^{6}$ Embora destacamos as interlocuções econômicas do Triângulo com São Paulo, cabe aqui salientar que a região mantinha ligações igualmente importantes com o centro de Minas, ainda que a conjectura futura da região aponte o gradual estreitamento dos arranjos econômicos com São Paulo.
} 
Mineiro não resultou de determinações internas, mas das transformações econômicas e sociais que ocorreram em São Paulo." A respeito da estrutura das cidades com a chegada da Mogiana, Brandão (1989, p.93) atesta que

[...] as ferrovias trouxeram grande dinamismo para o Triângulo. Dentre os fatores positivos, cabe destacar que o impacto sobre o mercado de terras (rural e urbano), a infra-estrutura urbana (prédios, algumas demandas intersetoriais, etc.), a implantação de oficinas de reparos e o investimento em serviços de transporte fluvial. (BRANDÃO, 1989, p.93)

No início do século $\mathrm{XX}$, o quadro populacional da região já demonstrava os efeitos na dinâmica econômica das cidades pelo desenvolvimento dos sistemas de escoamento de produtos, a começar pela instalação das estradas de ferro no Triângulo. Tomando como referência 1920, Uberaba figurava, nesse ano, como maior cidade da região, passando em população a cidade de Araxá. Nesse ano, as maiores cidades, em população, eram, por ordem: Uberaba com 59.807 mil habitantes, Araxá com 46.866 mil habitantes, e Patrocínio, com 44.067 mil habitantes. Do final do século XIX a meados do século $X X$, vemos no dinamismo das transformações desse quadro populacional, a imagem da consequência da implantação da ferrovia, e daí por diante, o embate entre as cidades pela hegemonia econômica do Triângulo através do escoamento de produtos.

A atividade comercial no Triângulo Mineiro, nas primeiras décadas deste século, incentivou o crescimento econômico de algumas de suas cidades, e ainda fez com que fossem criadas novas aglomerações urbanas, levando a uma divisão intra-regional, em que esses núcleos foram se especializando, tanto na criação de gado (Uberaba); como na produção de cereais (Sacramento e 
Conquista) e na distribuição de mercadorias a nível extrarregional (Araguari e Uberlândia). As cidades do Triângulo Mineiro que mais se beneficiaram dessa nova ordem econômica, até o final dos anos 30 deste século, foram Araguari, Uberaba e Uberlândia. (SOARES, 1995, p.68)

\begin{tabular}{lccccc}
\hline \hline MUNicíPIO & $\begin{array}{c}\text { População } \\
\text { Municipal }\end{array}$ & $\begin{array}{c}\text { População } \\
\text { Urbana }\end{array}$ & $\begin{array}{c}\text { Focos } \\
\text { Iluminação }\end{array}$ & $\begin{array}{c}\text { Casas } \\
\text { Iluminadas }\end{array}$ & $\begin{array}{c}\text { Abastecimento de } \\
\text { Água }\end{array}$ \\
\hline \hline Araguari ........ & 27.129 & 8.700 & 450 & 870 & - \\
Araxá ........... & 46.866 & 3.690 & 370 & 371 & 574 \\
Conquista ..... & 17.206 & 1.952 & 200 & 108 & 102 \\
Estrela do Sul & 16.811 & 1.470 & - & - & 96 \\
Frutal ........... & 28.549 & 1.554 & 375 & 795 & 925 \\
Ituiutaba ....... & 20.772 & 1.992 & 300 & 160 & 143 \\
Mte. Alegre ... & 10.987 & 2.790 & - & - & 132 \\
Mte. Carme lo & 24.768 & 1.152 & 200 & 120 & 97 \\
Patrocínio ...... & 44.067 & 3.150 & 282 & 150 & 200 \\
Prata ............. & 11.800 & 1.872 & - & - & 146 \\
Sacramento .... & 34.889 & 3.054 & 295 & 285 & - \\
Tupaciguara ... & 9.960 & 1.806 & - & - & 487 \\
Uberaba ......... & 59.807 & 19.338 & 440 & 1.830 & -
\end{tabular}

6. Infra-estrutura Urbana das principais cidades do Triângulo Mineiro, em 1920. Fonte: SOARES, 1992.

No ano de 1950, Uberlândia e Araguari apareceriam, respectivamente, como segunda e terceira maiores cidades em população do Triângulo Mineiro, continuando Uberaba, ainda que por pouco tempo, a maior cidade da região. ${ }^{7}$ Aí, em meados do século XX, o quadro populacional já começara a expressar o desenvolvimento das cidades, que hoje figuram como as maiores do Triângulo, a começar pela "escolha" da Mogiana pelas localidades que fariam parte do

\footnotetext{
${ }^{7}$ De acordo com Freitas e Sampaio (1985), em 1950, as maiores cidades do Triângulo Mineiro e Alto Paranaíba eram: Uberaba (61.008 hab), Uberlândia (54.984 hab), Araguari (43.305 hab), Ituiutaba (24.521 hab), Tupaciguara (21.171 hab) e Patrocínio (21.714 hab).
} 
trajeto de sua linha férrea, e por conseguinte o avanço das políticas para as facilidades no escoamento de produtos, dentro dos trâmites comerciais.

Nesse processo de importantes alterações na dinâmica econômica do Triângulo, a instalação das estradas de rodagem tiveram um papel indispensável ao passo que atuaram como o fator que conseguiu alterar significativamente a economia e o desenvolvimento das cidades, de modo a formar uma estrutura que caracteriza ainda atualmente a dinâmica econômica regional, onde a cidade de Uberlândia é a que mais se beneficiara, a ponto de podermos afirmar que essa cidade "cresceu e desenvolveu-se sob o signo das estradas de rodagem" (SOARES, 1995, p.70).

As estradas de rodagem, tais como as estradas de ferro, ganharam mais atenção e sistematização em meados do século XX. Após a Proclamação da República, um plano de viação foi apresentado, especificamente em 1890, o qual deu origem à algumas ações do Governo Republicano. Observam Mesquita e Silva (2006), que além de fundamentarem-se basicamente em uma visão expansionista, somava-se o raciocínio geográfico simples - ainda que em uma visão ousada de interconexão marítima-hidroviária-ferroviária - de reaproveitamento das bacias hidrográficas, o que para a região do Triângulo Mineiro e Alto Paranaíba significava o favorecimento de suas cidades ao passo da condição geográfica do território.

Os mesmos autores contam que, a partir da década de 1920, uma febre rodoviarista desencadeou políticas no setor rodoviário em detrimento aos investimentos no ferroviário, onde a figura de Washington Luís - então governador do estado de São Paulo e posteriormente na presidência da república - teve papel importante, cuja afirmativa verifica-se por sua frase conhecida: "governar é abrir estradas". Nos planos $^{8}$ surgidos nesse período,

\footnotetext{
${ }^{8}$ À exemplo dessa época, pode-se citar o Plano Catramby de 1926 e o Plano Schnnor de 1927. (MESQUITA; SILVA, 2006)
} 
que ainda eram deficientes em implantação sistemática, via-se a presença da região do Triângulo Mineiro e sudoeste goiano como conexão da rede viária.

Nesse processo de construção e exploração de estradas de rodagem, Uberlândia teve papel fundamental, muito ligado a figura de Fernando Vilela de Andrade, com o empreendimento que culminou na criação, em 1912, da Companhia Mineira de Auto Viação, primeira construção de estrada de rodagem do centro-oeste, mais tarde incorporada pela BR-365. É, segundo Brandão (1989), com a construção da Companhia Mineira - beneficiando-se, também da estrutura ferroviária existente - que o papel de Uberaba como pólo irradiador dos fluxos, é passado à Uberlândia, que se favorecia do desenvolvimento rodoviário, tentando consolidar uma infra-estrutura de transportes e comunicações que garantisse um escoamento rápido e contínuo dos produtos agropecuários de Goiás, Mato Grosso e do próprio Triângulo.

Fortalecendo-se através do comércio atacadista, o que atualmente lhe rendeu o título de "pólo atacadista" brasileiro, Uberlândia se beneficiou da "era rodoviária", em uma conjuntura que até então, no começo de século $\mathrm{XX}$, apontava Uberaba, como "boca do sertão", e Araguari como "ponta de linha". "Enquanto a ferrovia concentra atividades comerciais, o transporte rodoviário flexibiliza e descentraliza a distribuição de mercadorias", nas palavras de Guerra (1998, p.52). Uberaba, Araxá, e Araguari perdiam o domínio comercial que exerciam, a primeira voltando-se para produção de gado, a segunda à exploração das águas termais.

Mesquita e Silva (2006) apontam que essa inversão das cidades em importância econômica, foi inflada pela decadência das estradas de ferro da Mogiana - ainda que essa tenha sido essencial no desenvolvimento conjunto de redes de transporte intermunicipais - sentida desde a década de 1930, e agravada pela concorrência dos investimentos do país que favoreciam o setor rodoviário. Pode-se adiantar aqui que essa decadência do setor ferroviário teve 
um impacto decisivo na escolha por uma linguagem moderna na arquitetura das novas estações da Mogiana, o que coloca em pauta o imaginário político e populacional que circunda o "moderno brasileiro" dentro de uma estratégia empresarial: as antigas estações de trem eram vistas como um entrave ao progresso regional, indo à contramão ao progresso do país.

Ainda que Uberlândia se beneficiasse da "era rodoviária", junto a localização estratégica do Triângulo Mineiro dentro do território nacional, isto é, seguindo as propostas expansionistas governamentais, o Triângulo Mineiro como um todo era favorecido pela malha rodoviária que, em sequência, formava-se em toda região. Mesquita e Silva (2006) citam que, à exemplo de Vilela, outras estradas surgiram na região, como a de Uberaba, idealizada pelo Cel. Quirino Luíz da Costa, que possibilitou a expansão da rede de estradas de rodagem, ao conectar-se às estradas da Companhia Mineira de Auto Viação. Essas iniciativas, segundo os autores, conduziram, até a década de 1940, a formação da malha rodoviária do Triângulo Mineiro, que se tornaria "embrião da futura rede a ser consolidada com a pavimentação levada a cabo nos anos 1950, 1960 e 1970" (2006, p.55). Esse embrião da atual malha rodoviária se fixaria como modelo definitivo, quando em 1938, o Plano Rodoviário Nacional prevera a integração do território nacional através de estradas de rodagem, ainda que consolidando-se apenas na década de 1950, no governo JK. 


\section{O Triângulo Mineiro a Partir do Plano de Metas de JK}

Até meados da década de 1950 o Triângulo Mineiro tirara proveito do seu posicionamento estratégico no território brasileiro e ia ganhando autonomia à nível nacional ao mesmo tempo em que se favorecia dos planos de desenvolvimento do Estado. Nessa conjuntura, Brasília aparece como resultado do processo de desenvolvimento da região, que se fortaleceria com o deslocamento da capital federal para o Planalto Central. Não resta dúvidas de que, para a aceitação popular e a produção de arquitetura moderna na região, as dinâmicas econômicas que envolvem o deslocamento da capital federal, em fins da década de 1950, e seus desdobramentos nos anos seguintes foram substanciais, onde podemos verificar a afirmativa, por exemplo, pelo compasso cronológico de forte produção moderna durante as décadas de 1960 e 1970, sobretudo na cidade de Uberlândia, a qual passará a ocupar o espaço de centro regional, tornando-se a cidade do Triângulo que mais se beneficiaria do deslocamento da capital federal. Por isso, retornaremos ao tema "Brasília" seguidas vezes nesse trabalho, tentando desdobrar os pesos da capital para a arquitetura brasileira, a produção moderna fora dos grandes centros e as notórias peculiaridades e importância do evento à produção moderna do Triângulo, cujo próprio histórico de sua condição geográfica tornara a proposição quase axiomática.

Há uma concordância dos autores ${ }^{9}$ que tratam do desenvolvimento da região acerca do impacto político, econômico e cultural que a construção de Brasília exerceu sobre o Triângulo Mineiro. Com a construção da nova capital, a posição geográfica estratégica da região transporia a qualidade de rota ao centro-oeste brasileiro para o peso de se tornar a rota de ligação entre a sede

\footnotetext{
${ }^{9}$ A exemplo, recomendamos a leitura dos trabalhos de Brandão (1989), "Triângulo: capital comercial, geopolítica e indústria", Soares (1995), "Uberlândia: da cidade jardim ao portal do cerrado."
} 
do Governo Federal - Brasília - e a sede do Poder Econômico - São Paulo. As políticas desenvolvidas no governo Vargas se consolidam por Juscelino Kubitschek com a efetivação do Planos de Metas, período caracterizado por um forte impulso econômico no Brasil, onde a fundamentação básica do Plano de Metas estava na obtenção de maior eficiência e justiça na alocação de recursos por meio do reforço da intervenção estatal.

Para Brandão (1989), o período iniciado pelo governo do presidente Juscelino Kubitschek (1956-1961) até meados dos anos de 1980 é o palco de um processo de consolidação de todas as determinações gerais que vinham possibilitando a inserção do Triângulo Mineiro na economia nacional, onde nos interessa "realçar a chamada Meta Síntese do Plano de Metas, a construção de Brasília, e a opção realizada pelo rodoviarismo - automobilismo, tendo como pano de fundo (condicionador) o forte desidrato geopolítico." (1989, p.129). Aí, novamente, é conveniente reiterar o discurso geopolítico de interiorização do país a fim de recordarmos a posição do Triângulo Mineiro na conjuntura político-econômica que vinha sendo feita:

[...] um dos temas mais reiterados pelo discurso geopolítico brasileiro, desde os seus primórdios, foi a necessidade de se interiorizar a capital federal, de transferi-la para o "Planalto central". Essa idéia normalmente vem interligada a outras, num conjunto onde aparecem os seguintes temas (e propostas de ação): a integração mais efetiva do espaço nacional; a ocupação do interior do país mediante uma "marcha para o Oeste"; o estabelecimento de uma divisão territorial (administrativa) "mais racional" do país; a construção de uma rede de transportes densa e eficaz, para facilitar a interiorização da economia e da população; a preocupação com as fronteiras do país; e o grande tema, que praticamente incorpora e norteia os demais, o de se estabelecer metodicamente um conceito de segurança nacional. (VESENTINI, 1986 apud BRANDÃO, 1989, p.130) 
Como território cercado por um ideal geopolítico, o Triângulo se consolidava como área de abastecimento da nova capital, cuja expansão da infra-estrutura na região cumpriu papel importante, em termos de adequação às novas atribuições requeridas pelo deslocamento da capital. Brandão (1989) estava certo de que o rodoviarismo-automobilismo, representou um "verdadeiro divisor de águas" na história do Triângulo Mineiro. Beneficiado novamente por sua posição geoestratégica, agora sob a lógica da máxima "todos os caminhos levam a Brasília", a região favorecia-se da expansão das malhas de rodagem que recortavam o país ${ }^{10}$, e das novas dinâmicas construtivas que brotaram a partir da necessidade de materiais de construção para a nova capital, onde Uberlândia foi a cidade na região que mais se favoreceu, conseguindo ultrapassar em população a cidade de Uberaba e consolidando-se, na década de 1960, como centro regional triangulino. Essas novas dinâmicas construtivas incidem diretamente na arquitetura moderna no Triângulo Mineiro e Alto Paranaíba, e são importantes para traçarmos os vários caminhos que possibilitaram a construção moderna nessas cidades. A produção de arquitetura moderna no Triângulo Mineiro foi, em diversos sentidos, em termos de construção e apropriação de uma nova linguagem, estimulada pela construção de Brasília.

\section{[...] a construção de uma cidade planejada para 500 mil habitantes} criou uma gigantesca demanda concentrada temporalmente [...] e espacialmente (era grande o isolamento do sítio onde foi erguida em relação aos fornecedores de materiais de construção e outros produtos demandados). O fornecimento adequado aos produtos necessários a um empreendimento de tal vulto teria que ser originário, ou de São Paulo (passando necessariamente pelo

\footnotetext{
${ }^{10}$ À exemplo: a BR-050, São Paulo - Brasília, que possibilitou a ligação asfáltica entre os principais centros urbanos do Triângulo; a BR-262, Uberaba - Belo Horizonte - Vitória, iniciada em 1962, que integrou a região à capital do estado; a BR-153, Araraquara - Frutal - Goiânia; a BR-363, Montes Claros - Uberlândia - Canal de São Simão; e a BR-452, Uberlândia - Araxá.
} 
Triângulo), ou das regiões centrais de Minas ou de Goiás. (BRANDÃO, 1989, p.131)

[...] com a construção de Brasília, grande dinamismo se instala no comércio e na agroindustria triangulina. Suas fabricas de manilhas, telhas, ladrilhos, cal, cimento, etc., e suas distribuidoras de madeiras, combustíveis, peças de reposição, etc., e de modo geral, todos os setores (inclusive serviços) tomaram grande ímpeto. A sua posição e experiência de grande empório comercial do CentroOeste foi intensificada uma vez que seus então recentes competidores, os centros atacadistas de Goiânia e Anápolis, não conseguiram suprir convenientemente (tanto em termos de estoques quanto de preços) as necessidades das obras da nova capital. Algumas cidades triangulinas alimentaram-se economicamente em tal vulto que se poderia dizer que (re)nasceram, como foi o caso de Monte Carmelo, grande parque cerâmico. (BRANDÃO, 1989, p.132)

Na posição de cidade que irá suprir as necessidades da construção de Brasília, Uberlândia cresce economicamente como pólo atacadista e com o crescimento de empresas que se especializavam na venda e distribuição de materiais de construção, visto o choque, alguns anos mais tarde, de alguns migrantes ao se depararem com tais tipos de lojas na cidade ${ }^{11}$. Cabe lembrar, que a construção de Goiânia, na década de 1930, para esses fatores, foi essencial como experiência e desenvolvimento das potencialidades da região.

Soares (1995) evidencia que a diversificação e intensificação do processo que levou Uberlândia a ser reconhecido hoje como pólo atacadista brasileiro, deve muito à construção de Brasília e a "modernização" da economia brasileira. Expandiram-se os mercados e modificaram-se as estruturas comerciais no que diz respeito à criação de empresas transportadoras, que se

\footnotetext{
${ }^{11}$ Relato da entrevista feita com a professora da Faculdade de Arquitetura da Universidade Federal de Uberlândia - FauEd/UFU, Maria Elisa Guerra, Setembro de 2012.
} 
diversificaram a partir da especificidade dos tipos de carga. É no período expandido da construção da nova capital que as grandes atacadistas - tais como Martins, Arcom e Peixoto - assim como as distribuidoras de petróleo Shell, Esso, Texaco e Atlantic - iniciaram suas atividades. ${ }^{12}$

A partir de Brasília, tem-se um Triângulo Mineiro consolidado como pólo armazenador, processador de produtos, distribuidor e redistribuidor atacadista de mercadorias, em um processo em que a região também avança em sua diversificação produtiva regional. O Triângulo passa pelo Golpe Militar de 1964 como parte de uma estratégia territorial geopolítica. Brandão (1989) destaca a instalação de grande contingente militar na região e a abertura de faculdades em Uberlândia, "além de outros benesses"13. Sob o lema "domina um território quem domina sua área central", a região do Triângulo foi se transformando

num verdadeiro posto avançado do capital, uma ponte por onde grande parte dos interesses expansionistas teriam que passar e estabelecer aí, dentre lideranças políticas locais, seus testas de ferro, daí a participação desses políticos nos quadros cupulares tanto a nível federal quanto estadual. (BRANDÃO, 1989, p. 136)

Nas primeiras décadas de 1970, a economia regional evoluiu a taxas superiores às registradas para a economia estadual. Uberlandense, Rondon Pacheco, governou o estado de Minas entre 1971 e 1975. Representou, seu governo, o apogeu da expansão industrial mineira. O início da década de 1970 caracterizou-se pela ampliação dos canais de negociações e reivindicações junto ao governo estadual (pelo governador) e pelas benefícios obtidos.

\footnotetext{
${ }^{12}$ Segundo Soares (1995), em 1953 iniciam-se as atividades dos Armazéns Martins, distribuindo bens de consumo não duráveis, e em 1965, as empresas atacadistas Armazém Peixoto e Armazém do Comércio (ARCOM) também passam a concorrer no setor.

${ }^{13}$ Segundo os relatos das pesquisas de Brandão (1989, p. 136), estas faculdades teriam "o objetivo explícito de se contrapor a 'idéias estranhas' (esquerdistas) que estavam se disseminando no Brasil Central". A Universidade Federal de Uberlândia foi fundada em 1969.
} 
Também, neste momento, uma estratégia para o quinquênio 1971-75 foi proposta, o $1^{\circ}$ Plano Mineiro de Desenvolvimento Econômico Social - PMDES, que em síntese, objetivava a "modernização da agricultura e a disseminação de unidades industriais pela 'periferia' do estado." (BRANDÃO, 1989, p.138) Segundo Brandão (1989), essas mudanças setoriais, à exemplo da produção industrial na agricultura, retratam os impactos econômicos do rápido processo de urbanização ocorrido na região. "É expressiva a participação das atividades comerciais (presumivelmente com elevação da participação relativa ao varejo), de serviços urbanos (água, luz, gás) e da construção civil." (BRANDÃO,1989, p.144)

Destacamos ainda nessa seção, o dinâmico processo de fluxo migratório urbano das décadas de 1970 e 1980 no Triângulo Mineiro e Alto Paranaíba, o qual tendia, como à âmbito nacional, a intensificação do êxodo rural. Revelam, sobretudo, a diversificação dos campos de trabalho no Triângulo Mineiro. Revertendo a tendência da década de 1960, quando a região era perdedora de população, ao longo da década de 1970, o Triângulo recebeu grande contingente populacional, sofrendo os impactos do fluxo migratório que se dirigia ao Centro-Oeste e Norte do país. Especificamente, no Triângulo Mineiro e Alto Paranaíba, esses fluxos se deram com maior relevo no próprio estado de Minas Gerais, na própria região do Triângulo Mineiro, nos estados de Goiás e São Paulo. Freitas e Sampaio (1985) explicitam que, para se ter uma ideia da dimensão dos fluxos migratórios urbanos, das 257.863 pessoas não naturais do município onde residem e que migraram para a mesorregião durante as décadas de 1970 e $80,37,2 \%$ vieram de fora de Minas Gerais, principalmente de Goiás e São Paulo. Certamente, os fluxos migratórios inferem direta e indiretamente na difusão de uma cultura, e não devem ser negligenciados na participação dos diálogos que envolvem a produção de nossa cultura arquitetônica. 


\section{Capítulo 2}

OS PRIMEIROS PASSOS PARA A PRODUÇÃO DE UMA ARQUITETURA MODERNA 



\section{Um Imaginário Moderno na Dinâmica Construtiva do Triângulo}

No primeiro capítulo, tentamos construir um quadro geral que nos demonstrasse aspectos importantes do desenvolvimento econômico da região. Mais do que isso, que pudesse nos dar indícios do próprio processo de produção da arquitetura moderna nas cidades do Triângulo Mineiro e Alto Paranaíba, na hipótese de que o desenvolvimento econômico das cidades, seus meios de produção e sua capacidade de produção são partes integrantes no desenvolvimento da nossa cultura arquitetônica moderna, isto é, fornecem os meios que possibilitam, dentro de um conjunto maior, a disseminação dessa nova técnica e estética arquitetônica. Desse modo, observamos que o desenvolvimento da construção civil $^{1}$ das nossas cidades avançava ao passo que a região tornava-se gradativamente imprescindível dentro de uma estratégia geopolítica de interiorização do país, chegando ao clímax com a construção de Brasília.

Não obstante, existe ainda, uma série de representações que envolvem a relação da região com o que podemos chamar de seu destino enquanto rota de passagem na ocupação do Brasil Central. Há um imaginário que se dissemina na população e é expresso em diversos setores da dinâmica citadina, seus jornais, suas propagandas, nos anseios da classe dirigente, nas reproduções culturais, e que culminam para os diversos entendimentos acerca da modernidade. Esse é um imaginário construído, sobretudo, através das políticas de modernização do país, dentre as quais, o Triângulo protagonizara desde as Bandeiras, adentrando com papel importante nas políticas de interiorização do Brasil. Como essas ideias perpassam nesse contexto histórico

\footnotetext{
${ }^{1}$ Lembramos, a exemplo, como dito no capítulo um, que o Triângulo se beneficiara com o excedente deixado pelo escoamento de produtos ao Brasil Central, onde obrigatoriamente, passaria pelo Triângulo. Grande excedente de materiais de contrução civil foi aproveitado, sobretudo, na construção de Brasília.
} 
regional? Como se disseminam em circunstância da própria cultura de trânsito e passagem dessa região?

Encontramos nas investigações e no material primário pesquisado, indícios de que essas representações da modernidade incidiram de maneira a construir uma cultura favorável à produção de arquitetura moderna no Triângulo Mineiro e Alto Paranaíba. Entendendo que o alastramento da arquitetura moderna se dá meio a processos e condições históricas, tentaremos construir aqui, ainda que brevemente, associações entre a condição histórica peculiar do Triângulo Mineiro e a sua produção moderna, onde o moderno, aqui, terá representações diversas, sobretudo na arquitetura. Partir das características próprias do Triângulo Mineiro e Alto Paranaíba para essa discussão é dar destaque, primeiro, à um fenômeno local, antes que nacional ou global, tentando assim, traçar um enredo particular, o que consideramos poder agregar aos estudos acerca da criação de cidades modernas periféricas.

No momento de introdução da arquitetura moderna brasileira na região do Triângulo, que se dá em fins da década de 1940 - com a Fonte Andrade Junior, no Conjunto Paisagístico para o Barreiro de Araxá - e ao longo dos anos de 1950 nas principais cidades, convivem juntas outras manifestações da modernidade na arquitetura, onde o art déco tem papel importante nas representações propagandísticas de "modernização", conjuntamente com a arquitetura eclética que vinha já sendo produzida. Consideramos não negligenciar alguns desses tipos de "modernização" processados na região, que se manifestam em diferentes níveis da cultura local, reconhecendo que fazem parte de uma discussão maior, que é a do imaginário moderno brasileiro.

$\mathrm{Na}$ documentação encontrada ao longo desse trabalho, percebeu-se que esse imaginário, que rodeia o entendimento do "moderno", estivera vinculado por vezes à ligação da região com São Paulo, fruto da própria dinâmica econômica do Triângulo com a capital paulista (como vimos no 
primeiro capítulo); ao papel estratégico da região enquanto rota para o Brasil Central, onde a ideia de progresso mesclava-se com a de modernidade, observadas principalmente as expressões utilizadas na imprensa local; e também à produção em art déco, uma arquitetura reconhecida popularmente como moderna e que se tornara peça de uma estratégia política, na construção de uma representação, que diz respeito à um ideário vinculado ao que se entedia ser uma "cidade moderna".

Iniciamos a abordagem dando relevo às manifestações separatistas do Triângulo Mineiro e Alto Paranaíba, as quais pode-se afirmar serem fruto da própria disputa em que o território se envolveu até pertencer definitivamente ao estado de Minas, em 1816. Esses movimentos emancipacionistas existem ${ }^{2}$ desde meados do século XIX e confundem-se com a própria expansão da região, onde influenciaram muitas vezes na sua configuração territorial. O Movimento Separatista Triangulino revela, especialmente, a frágil relação da região com o estado de Minas Gerais (percebida ainda atualmente), somado ao anseio de uma classe dirigente em estreitar as relações, mais que economicamente, com São Paulo.

[...] o triangulino não cultiva a mineiridade. Esta região tem sido ponto de apoio estratégico das grandes rotas nacionais Norte/Sul, Leste/Oeste. Deste processo de acumulação gerado pelo permanente convívio, assimilamos um comportamento cosmopolita, universal. Somos todos forasteiros, bem vindos e integrados. - Ex-vereadora Martha de Freitas Pannunzio durante o último movimento separatista, no final dos anos 80. (CORREIO DO TRIÂNGULO, 03.10.87:02 apud SOARES, 1995, p.56 - grifo nosso)

\footnotetext{
${ }^{2}$ As propostas emancipacionistas do Triângulo MineirO e Alto Paranaíba estão em pauta ainda atualmente.
} 
As manifestações separatistas do Triângulo Mineiro foram recorrentes e incidiram com força, principalmente ao longo dos anos de 1970, mas foram se tornando cada vez mais um tipo de "moeda de troca" para reivindicações feitas ao próprio estado de Minas, como o rebaixamento de tarifas tributárias. ${ }^{3}$ (FERNANDES, 2008) Apesar do Movimento Separatista Triangulino tomar um forte impulso a partir da segunda metade da década de 1960 - quando ganhou maior expressão política a nível nacional e estadual - foi no início do século XX, a expressão da crescente condição regional de periferia ligada à São Paulo, onde a instalação da ferrovia ${ }^{4}$ exerceu papel substancial: aproximava o Triângulo da capital paulista da mesma forma em que o afastava do restante de Minas.

Segundo Hidelbrando Pontes, agrônomo, memorialista responsável pela retomada da campanha pela separação do Estado do Triângulo no início do século $X X$, ao demonstrar a facilidade dos traslados até São Paulo - feito em três dias à época - revelava também que o fácil diálogo nos trâmites com a capital paulista incidia culturalmente no triangulino. E, ainda que, de maneira mais desejosa que real, ia culminando em discursos ao longo desse processo histórico tal qual o de que "assimilamos um comportamento cosmopolita", isto é, central, paulistano, transitado desde o centro do capital brasileiro para o oeste, onde o trem se transformara no principal mediador.

[...] o Triângulo passava alheio a tudo o que dizia respeito à Minas, dependendo inteiramente de São Paulo. [...] Para se ir, v.g., diretamente de Uberaba a Belo Horizonte, ter-se-ia que fazer o trajeto Uberaba - São Paulo - Barra do Piraí - Belo Horizonte, ou

\footnotetext{
${ }^{3}$ Fernandes (2008) destaca que o Movimento Separatista Triângulino foi representativo de uma indignação de classe, que se sentia lesada fiscalmente pelo estado, e menos um movimento popular, com reinvidicações de mudanças sociais. Apesar disso, a questão da "mineiridade" triangulina não é tão apelativa quanto parece. Visto a condição de território de divisa, e às fortes ligações econômicas com seus estados adjacentes, transparece também culturalmente ligações que são por vezes mais próximas à do estado de Goiás e do interior paulista.

${ }^{4}$ A chegada da ferrovia no Triângulo Mineiro e Alto Paranaíba se deu no final do século XIX, com a Companhia Mogiana de Estradas de Ferro. (Ver mais no capítulo 1)
} 
seja, quatro dias. (PONTES, 1978 apud LOURENÇO, 2007, p. 155)

Existia um fluxo cultural tramitando pelas linhas da Mogiana. Existia um imaginário difundido, em que o trem era substancial, principalmente, no que diz respeito aos laços, à assimilação e absorção da cultura paulistana, circulado meio ao fluxo de pessoas, ideias e mercadorias no trajeto da Mogiana dentro do território do Triângulo Mineiro. Nas construções, o ecletismo demonstra uma dessas incidências, do ideário trazido pelo trem para a arquitetura triangulina, anterior e mesmo simultânea à introdução, de fato, da arquitetura moderna em meados da década de 1940. Já no final do século XIX, a arquitetura eclética está presente por toda região, em endereços diversos, sejam institucionais, residenciais e nas fazendas às margens das linhas do trem.

A arquitetura eclética que ia sendo introduzida traz a relação entre a Mogiana, o imigrante e a construção. Muitas dessas pequenas estações de trem foram construídas por imigrantes italianos (como a Estação de Conquista) vindos pelo trânsito São Paulo/Centro Oeste. O imigrante ia se tornando o sangue novo da mão de obra e no gosto de morar das classes abastadas, como continuidade da própria absorção cultural europeia que nos recorreu arquitetônicamente com muita força até a disseminação do ideário moderno brasileiro na busca pela assimilação da cultura nacional.

Em Uberaba, os principais construtores desse estilo são imigrantes italianos. O eclético do imigrante chegara a se tornar exigência na cidade, pelas que ficaram conhecidas como Leis de Fachadas ${ }^{5}$, as quais vieram a modificar o feitio das construções já no fim do século XIX, onde ruas tiveram seus prédios reformados de modo a figurar o eclético em toda fachada que não tivesse ainda um estilo qualquer. Uberaba ia ganhando outro aspecto com as fachadas

\footnotetext{
${ }^{5}$ NABUT, João Alberto. O ecletismo em Uberaba - uma trajetória de imigrantes, de João Alberto Nabut. Disponibilizado por: Arquivo Público de Uberaba. s/d.
} 
trabalhadas em relevo pelos imigrantes. A exigência da prática do ecletismo em forma de lei explicita nesse momento o apelo pela mão de obra imigrante, que vinha ocupar o espaço "vago" deixado pela libertação dos escravos, poucos anos antes.

Em texto publicado em um jornal local da cidade, "O ecletismo em Uberaba - uma trajetória de imigrantes", João Alberto Nabut ${ }^{6}$ já reconhece que há na exigência por fachadas ecléticas um ideal de "modernização", sustentado sobretudo por um fascínio pela cultura europeia, mas que demonstra também um rompimento com o passado mineiriano e colonial, de aspecto "pobre", em contraposição aos elementos funcionais que eram introduzidos com o eclético, a importação das telhas francesas, os complicados desenhos no assoalho e forros de madeiras diversas, a calha escondida pelos lambrequins no beiral da fachada frontal, a novidade do vidro colorido, as aberturas para os jardins laterais, a platibanda, etc.

Do que não podemos fugir é do conceito de moderno, funcional e universal que tem o ecletismo para a sociedade brasileira e uberabense na virada do séc. 19. Esse conceito logo atingiu vereadores e agentes executivos nos primeiros anos da República, mais precisamente em 1893, quando a Lei das Fachadas impõe explicitamente a nova feição das construções, exigindo platibanda em todas as fachadas. E a platibanda é uma das manifestações da nova arquitetura que disfarça a 'pobreza' do casario tradicional e colonial de 'arapuca' e 'caixões portugueses'. Esse mesmo casario de irregularidade nos telhados feitos de paus roliços sob telhas de capa e canal, cujas formas são da coxa do escravo, na qual se molda o barro. ${ }^{7}$ (Grifo nosso)

\footnotetext{
${ }^{6}$ Idem

${ }^{7}$ Idem
} 
As construções ligadas à ferrovia, como modelo arquitetônico paulista, e como diálogo com a cultura do imigrante erudito, permeiam as interlocuções entre a cultura de trânsito e passagem do Triângulo, o trem e seu anseio progressista. A arquitetura eclética, vislumbrada a partir dos diálogos com o imigrante, a arquitetura trazida pelos italianos, de certa forma correspondia ao processo histórico e econômico da região, atrelado em sua essência à economia paulista. Era a arquitetura do café a arquitetura eclética das pequenas estações, a arquitetura que representava o ideal cultural regional de aproximar-se também da cultura paulista, e que ocasionou vários episódios do Movimento Separatista Triangulino.

Na visão da elite local, a arquitetura eclética denotava a relação que em grau já existia e que noutro era perseguido, a vontade de integra-se totalmente à São Paulo, pela arquitetura, pelos costumes eruditos do imigrante, pelo que vinha sobre o símbolo da "modernização" triangulina, os trilhos da Mogiana: "Decididamente não seríamos mais mineiros, e certamente, os ideais separatistas brotaram aí, quando "descobrimos" o mundo, o Brasil e a nós mesmos. Quando nos tornamos ecléticos." ${ }^{8} \mathrm{E}$ a ideia transmitida pela palavra "mundo" é a de centralidade, representada pelo centro do capital econômico, São Paulo. Há nela o imaginário do cosmopolita, que atravessa a fronteira até o interior brasileiro pelas linhas do trem, e que traz consigo um ideal cultural que passa a ser expresso, também, na arquitetura, e que vale na busca de um novo modo de vida.

Na imprensa local, em toda década de 1950, o discurso assimilado pela importância geoestratégia do Triângulo Mineiro é visível em expressões diversas, onde se utiliza do principal escopo desenvolvimentista da região em alusão ao progresso que é perseguido. Na Revista Uberlândia llustrada ${ }^{9}$,

\footnotetext{
${ }^{8}$ Idem

${ }^{9}$ Para mais, recomendamos: LIMA, Sandra Cristina Fagundes de. Uberlândia Ilustrada, 1935 a 1961: a revista e seu editor. História e Perspectiva (36 - 37): 209 - 246, jan. Dez. 2007.
} 
folhetim municipal redatado e editado por Jerônimo Arantes, com vinte e oito números, entre 1935 e 1961, eram expressões tais quais "Uberlândia, porta larga do Brasil Central", "Cidade chave na rota de Brasília", "A metrópole Triangulina", "Ordem e Progresso", "A encantadora e rica Cidade Jardim", as chamadas dos textos e reportagens que descreviam ao leitor uberlandense a importância da cidade na estratégia econômica nacional, e a cidade que se pretendia progressista.

A revista utilizou diversas vezes de imagens de edifícios locais em alusão ao progresso que pretendia propagar. Os edifícios escolhidos para estampar capas e reportagens realçavam o centro da cidade, onde a Praça da República ${ }^{10}$ se tornara um dos principais símbolos. Uma fotografia de seu jardim abriu o primeiro número da Uberlândia llustrada. No entorno da praça, outros edifícios foram escolhidos para figurarem na revista, como o Edifício do Fórum e a Matriz de Santa Terezinha, prédios de grandes proporções que pretendiam conotar a dimensão da cidade. Em decorrência dessa centralidade, esse entorno foi escolhido diversas vezes na seleção das imagens da revista. Era, à época, o centro comercial e financeiro de Uberlândia, onde também localizavam-se as principais lojas, agências bancárias, o primeiro grupo escolar e os cinemas. Lima (2007), em artigo publicado acerca do folhetim, relata que

A seleção das fotos impressas nas capas parece ter obedecido à um critério cuidadosamente observado, qual seja: evidenciar as imagens que melhor representam o ideário progressista tão caro às elites locais. Dessa forma, Arantes tentou contemplar vários aspectos passíveis de monumentalizar a cidade e, por conseguinte, a sua própria revista. (LIMA, 2007, p. 231)

${ }^{10}$ Que deu lugar à Praça Tubal Vilela, projeto moderno de João Jorge Coury. 
Como representações do progresso, essas arquiteturas iam se tornando ícones do desenvolvimento da cidade ao passo em que eram monumentalizadas cada vez que apareciam no folhetim. A arquitetura moderna que começa a ser introduzida na cidade em meados dos anos de 1950 também passa a ser publicada nas páginas da revista com semelhante estratégia, onde a palavra "moderno" começa a ser associada à nova arquitetura funcional. No folhetim, foram destacados os edifícios do Uberlândia Clube, da Sociedade Médica, e os primeiros exemplares da verticalização da cidade, o Edifício Drogasil e o Edifício Tubal Vilela, todos esses, também, primeiros exemplares da arquitetura moderna de Uberlândia. As fotografias desses edifícios - algumas vezes, perspectivas do projeto ao lado de uma fotografia do prédio em fase de construção - eram acompanhadas por legendas que inflavam suas respectivas dimensões, o avanço tecnológico-construtivo e a beleza de suas formas: "O suntuoso edifício da Sociedade Médica"11; "Projeto do majestoso Edifício da Sociedade Médica de Uberlândia"12; "O rico edifício do Uberlândia Clube"13; "O maior arranha-céu do Triângulo Mineiro, que é o monumento Edifício Tubal Vivela"14, "A maior obra de cimento armado do Triângulo"15; "À Drogasil, cabe a primazia de ter construído o primeiro 'arranha-céu' da cidade, no ano de $1957^{\prime 16}$. Gradativamente, pode-se dizer que a arquitetura moderna ia sendo assimilada pela população citadina como referência de beleza, do avanço econômico da cidade e no entendimento do moderno, como técnica e forma arquitetônica.

No centro da cidade elevam-se as construções de maior vulto, como sejam os luxuosos edifícios do Uberlândia Clube, Edifício Finotti e o Edifício da Sociedade Médica, caríssimas construções

\footnotetext{
11 UBERLÂNDIA llustrada. Uberlândia, n. 20, dez. 1955. APU.CPJA

12 UBERLÂNDIA llustrada. Uberlândia, n. 16, jun. 1953. APU.CPJA

${ }^{13}$ UBERLÂNDIA llustrada. Uberlândia, n. 20, dez. 1955. APU.CPJA

${ }^{14}$ UBERLÂNDIA Ilustrada. Uberlândia, n. 22, set. 1957. APU.CPJA

${ }^{15}$ Idem

${ }^{16}$ UBERLÂNDIA llustrada. Uberlândia, n. 24, Jun. 1958. APU.CPJA
} 
residenciais de moderna arquitetura, nada influenciando a marcha acelerada no afan de construir-se muito, o preço caríssimo dos materiais e mão-de-obra empregados. ${ }^{17}$

7. Edifício Tubal Vilela, e à sua esquerda, o Edifício Drogasil. Fonte: Arquivo Público Municipal de Uberlândia.

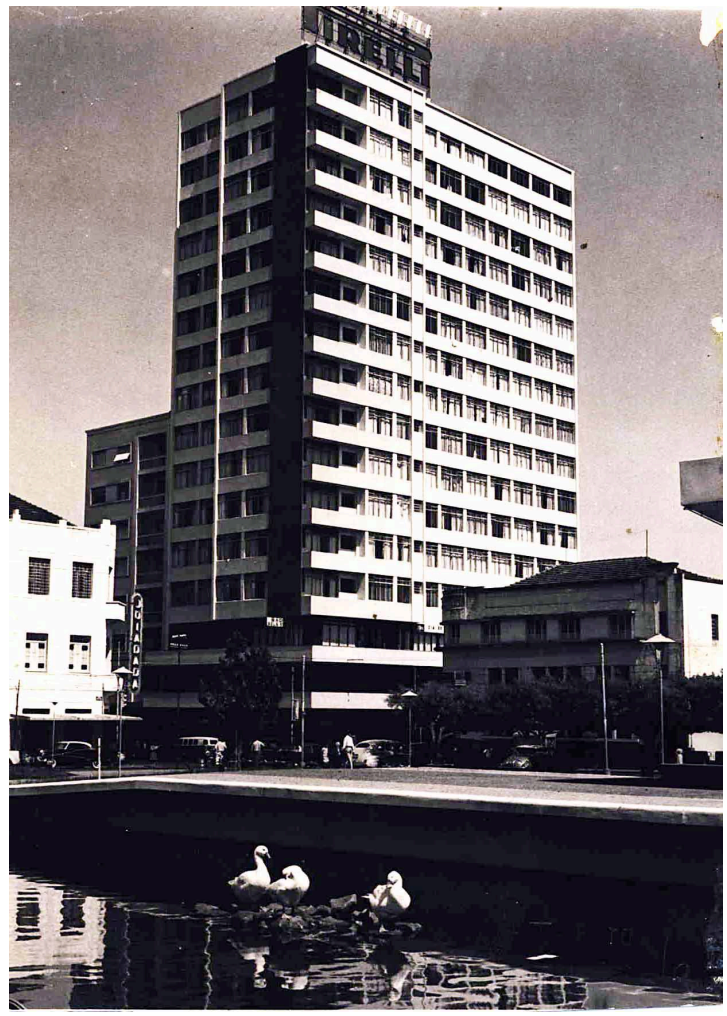

${ }^{17}$ UBERLÂNDIA, porta larga do Brasil Central. Uberlândia Ilustrada. Uberlândia, n.17, out. 1952. APU. CPJA 


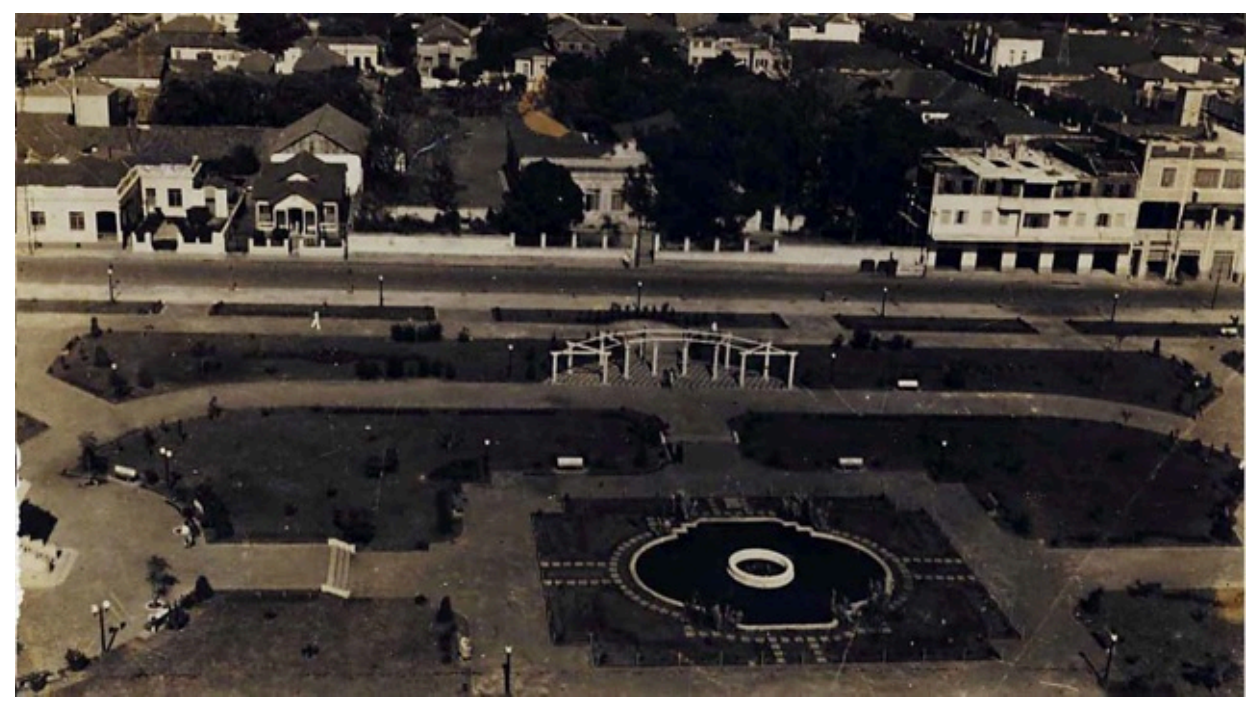

8. Praça da República, projeto anterior à atual Praça Tubal Vilela, de João Jorge Coury. Fonte: Arquivo Público Municipal de Uberlândia.

9. "Recorte da Revista Uberlândia Ilustrada, com a imagem do Uberlândia Clube. Fonte: UBERLÂNDIA Ilustrada. Uberlândia, n. 20, dez. 1955. APU CPJA

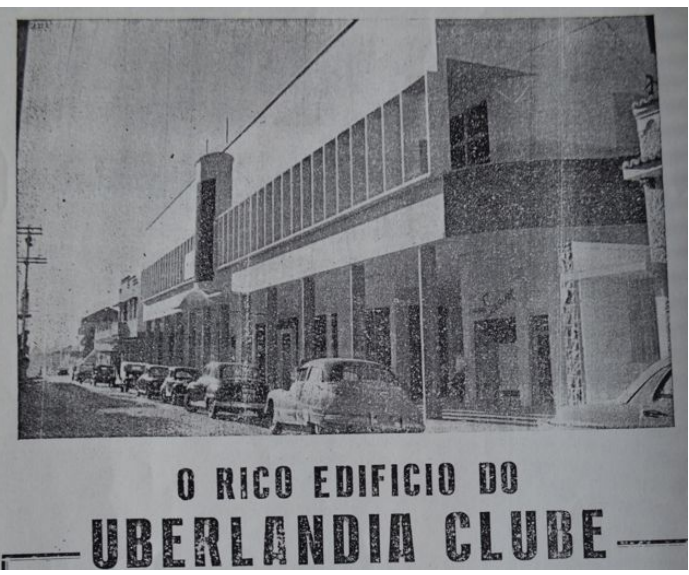

Em outra seção da revista, intitulada "Endereços Residenciais", algumas casas das famílias mais abastadas eram apresentadas com fotografias de suas fachadas, onde já se assiste à presença de algumas residências modernas. Nessas imagens, vê-se uma arquitetura com elementos típicos da arquitetura moderna brasileira - elementos vazados dispostos nas fachadas, esguios pilares sustentando uma marquise, a cobertura plana - dentro de uma composição bastante harmônica, como as obras de João Jorge Coury, arquiteto que se fixou em Uberlândia, o qual apresentaremos adiante nesse mesmo 
capítulo. Sua residência projetada para o Sr. Bolivar Carneiro, delineava, junto à outras residências de variados estilos, o perfil de uma importante via da cidade, a Avenida João Pinheiro ${ }^{18}$, cuja redação descreveu como "o centro residencial da cidade, onde se erguem suntuosos palacetes e encantadoras vivendas de fino trato." 19

Em geral, pode-se prever que a imprensa triangulina teve papel importante na dinâmica construtiva da região. Percebe-se em Uberlândia, que os empresários de comunicação atuantes na década de 1960 são os mesmos que se beneficiavam de atividades da construção civil e da especulação imobiliária. Edson Garcia Nunes, empreendedor, "adepto da modernidade"20, dono da TV Triângulo, primeira emissora a se instalar em Uberlândia, em 1964, destacou-se por construir os primeiros arranha-céus da cidade, com a empresa de empreendimentos imobiliários Cegeb, e através da qual teria negociado também lotes na nova capital federal, Brasília. A emissora foi vendida em 1971 para os empresários Tubal Vilela Siqueira e Silva, Rubens de Freitas e seu irmão Renato de Freitas, políticos e empresários atuantes em outros veículos de comunicação da cidade, como o "Jornal Correio" e "O Triângulo".

Tanto Renato de Freitas como Tubal Vilela foram prefeitos de Uberlândia. Engenheiro civil pela politécnica do Rio de Janeiro (1949) e advogado pela Faculdade de Direito de Uberlandia (1965), Renato de Freitas fez carreira política além de ter realizado várias obras na cidade. Tubal Vilela teve uma atuação política mais forte e foi empresário em diversas áreas. Em 1952, fundou a Imobiliária Tubal Vilela S/A, e em 1959, criou a Tubal S/A Hotéis, Comércio e Indústria, empresas atuantes no processo de verticalização da cidade, na década de 1960.

\footnotetext{
${ }^{18} \mathrm{~A}$ avenida João Pinheiro tornou-se uma área nobre de Uberlândia quando passou a configurar, junto às avenidas Afonso Pena e Floriano Peixoto, as quais seguiam até a antiga estação da Mogiana, a parte nova da cidade.

${ }^{19}$ UBERLÂNDIA llustrada. Uberlândia, n. 26, dez. 1960. APU. CPJA

${ }^{20}$ Como era conhecido popularmente. Para mais, ver: TEMER, A. C. R. P. Edson Garcia Nunes e a TV Triângulo em Uberlândia: anotações sobre a história de uma emissora de televisão no interior. In: Alaic 2006, 2006, São Leopoldo. Alaic 2006. Bogotá: Alaic, 2006.
} 
A atuação de empresários do ramo da construção civil na imprensa regional dá indícios de que essa era uma relação permeada por interesses, onde era preciso influenciar e justificar ao leitor algumas ações urbanas. Nesse sentido, não descartamos a hipótese de que esses veículos de comunicação almejavam imprimir um ideal de cidade, apregoados com frases como "A Metrópole Triangulina", "Ordem e Progresso" e "Cidade Jardim²1, representando uma ideia de desenvolvimento e conseguindo legitimar seus empreendimentos urbanos. Há de se considerar, como bem explicita Fernandes (2008), que essa elite empreendedora necessitava

[...] de um ordenamento social específico e determinado que, mais que traçados de ruas, prédios e avenidas, pretendia traçar modos de viver, de habitar, de ocupar a cidade, ou seja, os próprios comportamentos necessários para que a cidade se tornasse industrializada e desenvolvida [...] (FERNANDES, 2008, p.37 grifo nosso)

A Uberlândia llustrada documentou também, talvez um dos maiores vislumbres da população uberlandense na primeira metade do século $\mathrm{XX}$ : a possibilidade de sediar a nova capital federal, antes da reiteração de sua mudança para o Planalto Central com a decisão pela construção de Brasília. Somente em 1948, foi decidido o acordo em que mantinha a linha histórica de implantação da nova capital no Planalto Central. Antes disso, uma linha divergente contestava em favor da construção da nova cidade no Triângulo Mineiro. Na década de 1940, há diversos registros na imprensa regional, descrevendo qualitativamente a região, no afã de ter no território, a sede do governo federal, como compila o trabalho de Guerra (1998):

\footnotetext{
${ }^{21}$ Fernandes (2008) aborda o termo "cidade jardim" como correspondente à políticas públicas de limpeza, dentro da ideia de "higienização das cidades modernas".
} 
Não é de hoje que se fala na mudança da capital da República para outro ponto do país. A questão varou a nossa história e tem condão de se apresentar sempre oportuna, jamais deixou de ser lembrada. Certa ocasião, pareceu que o assunto ia de fato ser resolvido com a criação do Distrito Federal no planalto goiano. Ultimamente o problema vem sendo abordado em bases mais objetivas, capazes de levar a uma solução satisfatória. Uberlândia, a próspera cidade mineira, seria elevada à categoria de Distrito Federal. Os apologistas da iniciativa encontram argumentos fáceis para a vitória de seu ponto de vista. Geograficamente Uberlândia satisfaz plenamente, está situada no centro do Brasil, em região de conhecida fertilidade, é ligada ao resto do país por rodovias e estradas de ferro. Além disso, trata-se de uma cidade moderna, suficientemente credenciada pelo alto nível de progresso que alcançou, a tornar-se a capital da República. Nas condições atuais, bastaria a construção de edifícios públicos e incrementar a edificação de prédios residenciais para as sedes das embaixadas e para abrigar a nova população constituída dos funcionários do Governo Federal. As vantagens seriam inumeráveis. A capital da República sairia do litoral e se localizaria no centro do país, segundo princípios da estratégia moderna. Além disso, andaria mais rápido o progresso para o 'hinterland', evitando-se o êxodo da população para as grandes cidades. ${ }^{, 22}$ (grifo nosso)

Uberlândia reúne condições ideais - Em segundo lugar, tão urgente me parece a solução do problema que me inclinaria pela mudança imediata para uma cidade existente, com as necessárias condições de conforto e higiene e que poderia servir de base, a criação de uma nova 'urbs'. Creio que todas as cidades do Triângulo mereceriam esta honra, mas inclino-me por Uberlândia, cujos arredores sobrevoei em companhia do Brigadeiro Eduardo Gomes, e que oferece as seguintes vantagens: possui prédios que podem desde logo, receber algumas repartições federais e uma larga planície, onde se podem erigir edifícios definitivos da nova capital brasileira. Também possui uma boa estrada de ferro e projeto

22 UBERLÂNDIA ILUSTRADA. Uberlândia, Jul, p. 12, 1946, in: GUERRA, M. E. (1998). As Praças Modernas de João Jorge Coury no Triângulo Mineiro. São Carlos, Dissertação (Mestrado), EESC USP. 
facilmente realizável de prolongamento da E. F. Paulista. É um centro rodoviário de comunicações com as mais remotas regiões do país. Seu campo de aviação é frequentado por grandes linhas nacionais e internacionais. Pode-se comunicar por telefone com o Rio. Tem outrossim, comunicações fáceis com Belo Horizonte e São Paulo, está próxima de Cachoeira Dourada e tem sido, por estas condições, escolhida para o ponto avançado das penetrações no Oeste, como as das religiosas, as da Fundação Brasil Central e a da expedição Roncador Xingú. Enfim Uberlândia, a meu ver, reúne as condições ideais de posição, salubridade, água potável, água para esgotos, quedas de água para energia elétrica e acessibilidade para vir a ser a futura capital do Brasil. ${ }^{23}$

O vislumbre documentado por diversos agentes da imprensa, a respeito da possibilidade surgida para a região sediar a nova capital federal, insere-se e fortalece o que pretendemos tratar aqui, a construção de um imaginário popular local. Era difundida a ideia de que estávamos inseridos em uma zona estratégica do país, capaz de estar inscrita em importantes discussões políticas e econômicas a nível nacional, imaginário esse sustentado por textos inflados de um certo ufanismo, onde qualidades eram expostas de forma exagerada e com orgulho excessivo, como visto acima nos textos que apresentam Uberlândia para nova capital. Esse enredo que atrela a região às ações federais correspondentes a implantação de Brasília não se finda na escolha da construção da nova capital no Planalto Central, em oposição ao Triângulo Mineiro. De meados da década de 1950 para seu fim, a imprensa regional, com destaque para a uberlandense, exibirá diversas vezes a região como "posto avançado de Brasília", reiterando o papel de território que suprirá em grande parte as novas demandas geradas pela construção da nova capital. Nesse

\footnotetext{
${ }^{23}$ O REPÓRTER. Uberlândia, 25 mai, p.1, 1946, in: GUERRA, M. E. (1998). As Praças Modernas de João Jorge Coury no Triângulo Mineiro. São Carlos, Dissertação (Mestrado), EESC - USP.
} 
momento, difundi-se pela imprensa local que "Uberlândia representará para Brasília, o que vem representando para São Paulo e Rio atualmente [...]."24

Não há dúvidas de que, para a aceitação popular e o avanço da produção moderna do Triângulo Mineiro e Alto Paranaíba, as dinâmicas que envolveram o deslocamento da capital federal, em fins da década de 1950, e sua popularização, por meio de sua divulgação na comunicação de massa, foram substanciais. A imprensa regional, nos arredores da data de inauguração de Brasília, em 21 de Abril de 1960, noticiaram dezenas de caravanas que saíram com destino à nova capital para as festividades da inauguração. São encontrados vários anúncios de voos para Brasília, que passavam pelas cidades de Uberaba e Uberlândia, pelas empresas aéreas Real, Convair e Vasp. Dezenas de empresas locais deram as congratulações ao presidente Juscelino Kubitschek pelo feito. Algumas dessas publicações traziam o desenho dos pilares do Palácio da Alvorada, em Brasília.

Várias centenas de turistas já chegaram a esta cidade para as festividades de instalação da nova capital federal. Os turistas chegam por todas as vias de transportes. Muitas integram as caravanas promovidas por empresas de turismo. ${ }^{25}$

Dezenas de caravanas de Uberlandenses dirigem-se para Brasília para as imponentes festividades inaugurais da nova capital brasileira. Carros, peruas e outros meios de transporte estão saindo há dias desta cidade com destino a ciclópica capital brasileira localizada no planalto. Calcula-se em quase mil o número de pessoas que daqui estão partindo com destino à Brasília. ${ }^{26}$

\footnotetext{
${ }^{24}$ UBERLÂNDIA Ilustrada. Uberlândia, n. 24, dez. 1958. APU. CPJA

${ }^{25}$ CORREIO CATÓLICO, Uberaba, 10 Abr. 1960.

${ }^{26}$ CORREIO DE UBERLÂNDIA, Uberlândia, 14 Abr. 1960.
} 
87. Empresa congratula a inauguração de Brasília. Fonte: CORREIO DE UBERLÂNDIA, Uberlândia, 21 Abr. 1960.

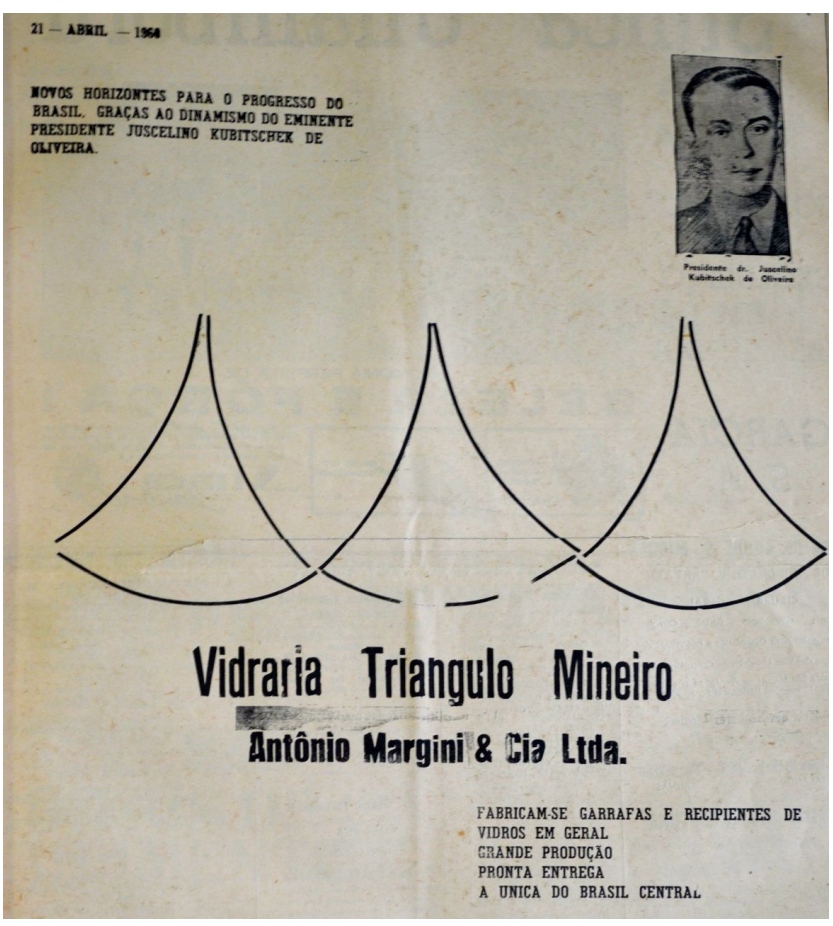

"Uberlândia será nome de arranhaceu em Brasília"27, anunciava um jornal local. No mesmo ano de 1960, muitas imobiliárias anunciaram a venda de apartamentos na nova capital, onde a imagem de um prédio moderno ilustrava a propaganda. Dentre as descrições, eram destacadas a beleza e a tecnologia dos sistemas e materiais construtivos, onde, novamente, a palavra "moderno" se mesclava ao entendimento de progresso. Esses anúncios traziam a descrição da composição moderna do projeto: "moderna arquitetura sôbre pilotis" ${ }^{28 ;}$ "fachadas totalmente de vidro e esquadrias metálicas." 29 Também, as empresas de materiais de construção passam a utilizar imagens de edifícios modernos nas propagandas. A arquitetura moderna parecia, nesse momento, agregar valor ao empreendimento. Na edição de 25 e Junho de 1960 do Jornal Correio de Uberlândia, um anúncio de uma imobiliária trazia a seguinte

\footnotetext{
${ }^{27}$ CORREIO DE UBERLÂNDIA, Uberlândia, 9 Out. 1960.

${ }^{28}$ CORREIO DE UBERLÂNDIA, Uberlândia, 18 Set. 1960

${ }^{29}$ CORREIO CATÓLICO, Uberaba, 10 Mai. 1960.
} 
chamada: Vá conhecer Brasília como proprietário! A passagem nós Ihe damos de graça!" 30

88. Anúncio de venda de apartamentos em Brasília. CORREIO DE UBERLÂNDIA, Uberlândia, 25 Jun. 1960.

\section{VA' COTHECER "BRASILIA COMO PROPRIETARIO ! \\ A passagem nós the damos, de "GRACA" ! Adquirindo um lore ou chácara, no Magnífica "CIDADE PRESIDENTE KUBITSCHEK" $10 \mathrm{me}$ Ihor loteamento de "Brasília") CIDADE SATELITE Você receberá, GRATIS, uma passagem de avião ida e volta, e conhecerá a nova "CAPITAL FEDE- \\ RAL" - Local do melhor negócio do momento? E' atravessade pela RODOVIA-S. PAULO-BELO HORIZONTE-BRASILIA! Registrada de acôrdo com o Decreto Lei 58 e 2784. Onibus atravessan- do o loteamento de meia em meia hora de BRA SILIA a CRISTALINA. Arruamento já iniciados e projetados. POSTOS DE GASOLINA - HOTEIS - IGREJAS - RESIDENCIAS - CAMPOS DE ESPORTES - ESCOLAS "SEU CAPITAL PE- QUENO APLICADO EM PRETACOES HOJE, VA- LERA' UMA FORTUNA AMANHA! \\ Mais um empreendimento da "PREDIAL DU- CHEN LTDA" PROCURE O CORRETOR AUTO- RIZADO DE VENDAS: \\ "RA MA L H O" \\ Rua Vigário Dantas, 545 - Uberlândia,}

Ainda no ano de 1960 foi divulgado um vídeo propagandístico apresentando o município de Tupaciguara, na época, sob gestão do prefeito Palmério Araújo Costa. Entre as décadas de 1950 e 1970, Tupaciguara não alcançou mais que cerca de vinte e cinco mil habitantes. ${ }^{31}$ Com quarenta e três minutos de duração, Tupaciguara é apresentada no vídeo com dezenas de adjetivos, dentre os quais a palavra "moderno" aparece como sinônimo de eficiência, competência, bom gosto, conforto, elegância, beleza, etc. Intitulado "Tupaciguara - terra da mãe de Deus", existe no vídeo um superdimensionamento da cidade e a construção de uma imagética, isto é, tenta-se exprimir por meio de um conjunto de imagens, previamente e estrategicamente escolhidas, a cidade, ou que se deseja construir ou que se deseja representar.

${ }^{30}$ CORREIO DE UBERLÂNDIA, Uberlândia, 25 Jun. 1960.

${ }^{31}$ Para se fazer uma comparação, no ano de 1950, Uberaba já se encontrava com cerca de 60.000 mil habitantes. Tupaciguara, no mesmo ano, tinha cerca de 21.000 habitantes, sendo a sexta maior cidade em população nesse período. Dado de Freitas (1985). 
Dessa forma, não é surpresa que a arquitetura moderna conquiste seu espaço na construção dessa imagética, posto, principalmente que, inaugura-se Brasília nesse mesmo ano e já existe uma imprensa comprometida em transmitir as conotações do progresso. Em "Tupaciguara - terra da mãe de Deus", são mostradas algumas residências modernas, dentre as quais duas conhecidas como projetos de João Jorge Coury" ${ }^{32}$ : "mostram o apurado bom gosto dos habitantes de Tupaciguara". Ainda que poucas dessas residências constituíssem um acervo moderno erudito, percebe-se que possuíam todas componentes que as caracterizavam popularmente como arquiteturas modernas. Seja algum elemento geometrizante como os relevos que emolduram as aberturas da fachada, os pilares esguios que sustentam a marquise de entrada, alguns em formato de " $v$ ", ou o telhado escondido na platibanda, elementos fartamente difundidos pela nova arquitetura brasileira. $\mathrm{Na}$ locução: "Tupaciguara já apresenta prédios residenciais de linhas modernas, mostrando o bom gosto de seus habitantes."

No entanto, no vídeo de Tupaciguara, é a arquitetura art déco que sustenta o ideal de "modernidade" transmitido. Após a apresentação das residências, logo no início do documentário, são em art déco a grande maioria dos edifícios mostrados, comércios e casas de serviços, em geral. Todavia, o discurso continua o mesmo: edifícios de "bom gosto", grande "eficiência", "elegantes", "bem instalados" e "modernos".

É vasto o conjunto arquitetônico em art déco em toda região do Triângulo Mineiro e Alto Paranaíba, onde pode-se suspeitar sua hegemonia na arquitetura popular da primeira metade do século XX. Sem dúvidas, é uma arquitetura que necessita ser investigada, sobretudo porquê convive de forma simultânea aos primeiros exemplares de arquitetura moderna em fins da década de 1940 e durante a década de 1950 na região. Há de se considerar

\footnotetext{
${ }^{32}$ Residência João de Oliveira Prudente, à R. Dr. Raul Carneiro, $\mathrm{n}^{\circ} 12$; Residência, atualmente propriedade da Sra. Susidally Pina Pereira, à R. 13 de Maio, 01.
} 
que nesse momento, assim como demonstra o vídeo de Tupaciguara, existem dois tipos de arquitetura, ambos identificados popularmente como "modernos". Que há uma assimilação em massa dessa arquitetura, que é de fácil produção em comparação, por exemplo, com o processo construtivo dos estilos clássicos, com grandes ornamentações - e tem suas correspondências com a industrialização.

Nessa produção, os cinemas constituem um acervo riquíssimo do art déco regional. Muitos já demolidos. Em Tupaciguara, o Cine Vitória, edifício tombado por lei municipal, é um exemplar exibido no vídeo documentário de 1960, descrito como "moderno e confortável". Alguns outros exemplos são o Cine União em Coromandel, o Cine Regente, o Cine Uberlândia e o Cine Éden em Uberlândia, além de outras tipologias menos monumentais, como os comércios em geral. Diversas vezes, o art déco forma o perfil de longos trechos de ruas e avenidas. É uma arquitetura que prima por uma composição de linhas e volumes, no uso de diagonais, onde predominam as formas geométricas em toda ornamentação - ou resquícios de uma ornamentação - dentro de um processo construtivo que vai se aproximando de um código formal racionalizante.

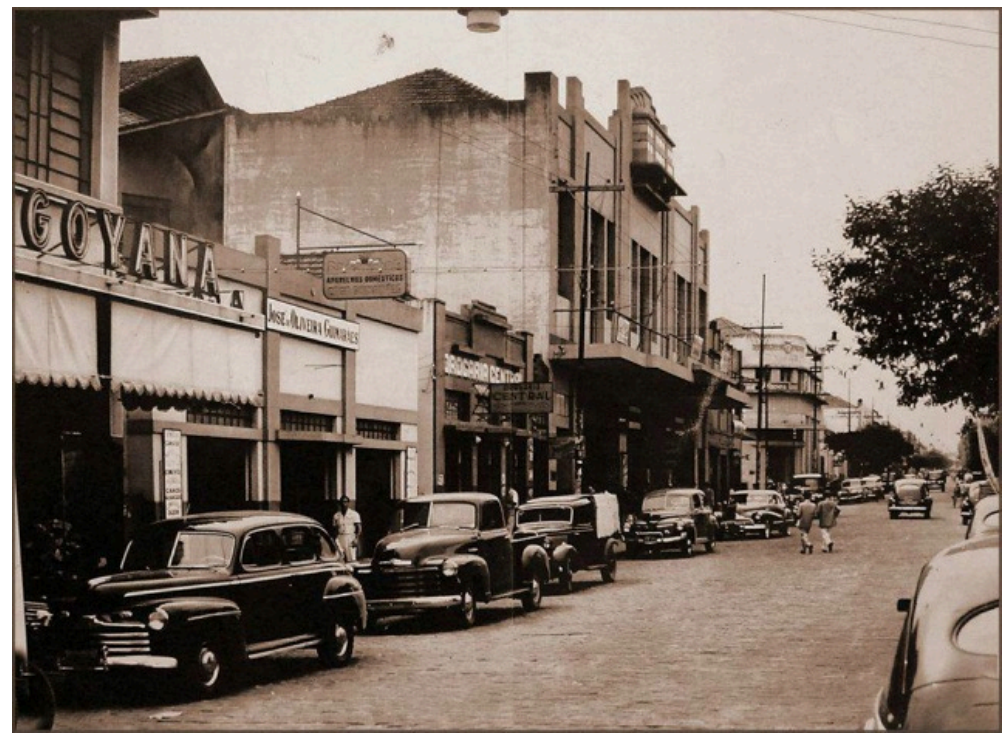

10. Cine Uberlândia, na Av. Afonso Pena, em Uberlândia. Fonte: Arquivo Público Municipal de Uberlândia. 
$\mathrm{Na}$ formação de uma cultura arquitetônica moderna no Triângulo Mineiro e Alto Paranaíba, a produção do art déco se dá meio um processo que novamente revela uma atitude e uma vontade moderna. Dentro de uma conjuntura regional específica, tal processo mostrou ter indícios semelhantes na arquitetura eclética, nos diálogos com a cultura paulista, no papel de rota estratégia e região abastecedora na construção de Brasília. São atitudes e vontades, sustentadas e infladas pela disseminação de um ideário progressista e "moderno", cujo papel da imprensa é substancial, permitindo-nos suspeitar que tal imaginário local, fruto do próprio processo histórico peculiar da região, incide na dinâmica construtiva dessa cidades, na produção de uma arquitetura moderna.

De fato, ao olharmos para a produção moderna erudita do Triângulo Mineiro e Alto Paranaíba, que se inicia em meados da década de 1950, vemos refletida uma produção que foi possível não somente pelos protagonismos de alguns arquitetos e personalidades políticas a partir desse período, mas, sobretudo, pelo quadro contextual pré existente, onde podemos incluir o imaginário moderno construído tempos antes da introdução, de fato, da nova arquitetura brasileira na mesorregião. 


\section{Marco Inicial: a Fonte Andrade Júnior no Conjunto Paisagístico para o Parque da Estância do Barreiro de Araxá}

A Fonte Andrade Júnior é a primeira obra de arquitetura moderna construída no território do Triângulo Mineiro e Alto Paranaíba, sendo projetada pelo arquiteto Francisco Bolonha, em meados da década de 1940, como parte do conjunto paisagístico para o Parque da Estância do Barreiro de Araxá, projetado por Roberto Burle Marx, em 1943. Pela divulgação que tivera, a Fonte Andrade Júnior de Bolonha coloca, pela primeira vez, a arquitetura moderna produzida no Triângulo Mineiro no circuito de obras inseridas nas discussões acerca do moderno produzido no Brasil e mesmo fora do país.

Burle Marx, não tendo formação acadêmica em arquitetura, passa o projeto da fonte para seu então estagiário Francisco Bolonha, que juntamente com o paisagista e o engenheiro Andrade Júnior (nome com a qual a fonte foi batizada) ficam encarregados de desenhar um edifício de linhas modernas para o parque. $O$ pequeno edifício destinava-se ao abrigo dos bebedouros para o aproveitamento da fonte de água sulfurosa e de raras propriedades medicinais encontrada na região. Junto a fonte, o projeto de uma nova praça de esportes também foi repassado à Bolonha, porém nunca foi executada.

Francisco Bolonha nasceu em 3 de Junho de 1923, em Belém do Pará, tendo ingressado no curso de arquitetura em 1940, na Escola Nacional de Belas Artes (ENBA), impulsionado pela carreira do tio homônimo, engenheiro, representante da arquitetura art nouveau da capital. Em seu primeiro ano de curso estagiou com o arquiteto Aldary Toledo, em seguida no escritório em conjunto dos arquitetos Jorge Machado Moreira, Oscar Niemeyer e Affonso Eduardo Reidy, enquanto também estagiava com Burle Marx, no período da noite. 
Com esses arquitetos ganhou experiência em diversas tipologias. Participou de projetos como o Hospital das Clínicas de Porto Alegre, com Moreira, o Teatro de Belo Horizonte, com Niemeyer, o concurso do CTA, com Reidy, o paisagismo da residência de Odete Monteiro e os jardins do Ministério da Educação e Saúde com Burle Marx, com quem estagiava nos períodos da noite. Ainda estudante, viu um projeto seu sendo publicado internacionalmente na revista L'Architecture d'Aujourd'Hui (1948, n. 21, capa e p.64-5) com desenho do arquiteto na capa da revista. Era o projeto premiado em terceiro lugar no concurso público para o Edifício Sede do Jóquei Clube do Rio de Janeiro, em 1947, em parceria com Israel de Barros Correa, e as colegas de turma Lygia Fernandes e Giuseppina Pirro. ${ }^{33}$

Bolonha formou-se pela Faculdade Nacional de Arquitetura da Universidade do Brasil ${ }^{34}$. No estado de Minas, fez carreira em Cataguases, na região da zona da mata, onde foi responsável, junto com Aldary Toledo, pelas primeiras manifestações da arquitetura moderna da cidade, muito em razão de sua amizade com os irmãos Francisco Inácio Peixoto e José Inácio Peixoto, empresários influentes na cidade, e do escritor Marques Rebello.

Bolonha fez carreira também: como arquiteto do Departamento de Habitação Popular do Distrito Federal, sob a supervisão de Carmem Portinho; na Divisão de Construções e Equipamento Escolar, onde foi diretor por quatro anos; nas empresas Bloch, quando teve a residência de Adolpho Bloch publicada como capa na revista italiana Abitare (1963, n. 16, maio, capa e p. 28-39), e mais uma vez na revista francesa L'Architecture d'Aujourd'Hui (1962, n.103, capa e p. 76-7); trabalhou na Divisão de Programas e Projetos do Banco

\footnotetext{
${ }^{33}$ Ainda estudante, Bolonha também publicou o projeto de um viveiro para pássaros na floresta da Tijuca, na Revista de Arquitetura do Diretório Central de Estudantes da ENBA. (MACEDO, 2003)

${ }^{34}$ Faculdade resultante do desmembramento do curso de arquitetura da Escola Nacional de Belas Artes, em 1945.
} 
Nacional de Habitação , o BNH; realizou dezenas de projetos para empresas de telecomunicações como a Cetel, Telebrás e Telemig. ${ }^{35}$

A Fonte Andrade Júnior, projetada em 1945 e inaugurada em 1947, constituiu a primeira obra de Bolonha construída com integridade de projeto. Os projetos para a fonte e para a praça de esportes, que não foi executada, Ihe renderam reconhecimento internacional quando publicados na Architectural Forum (1947, p.68-9), em número especial sobre o Brasil, e em 1948, quando a fonte foi classificada pela Architectural Journal de Londres como uma das melhores obras do ano. A Fonte Andrade Júnior no Barreiro de Araxá foi a obra que destacou Bolonha como arquiteto mais jovem e promissor da época. (MACEDO, 2003)

Francisco Bolonha permaneceu no escritório de Burle Marx até 1950. Oficialmente, a Burle Marx \& Cia Ltda foi fundada em 1955, localizada no bairro de Laranjeiras, zona sul do Rio de Janeiro. O escritório fazia trabalhos de execução e manutenção de obras paisagísticas, desde edifícios residenciais a obras públicas. Mesmo antes da oficialização da firma, Burle Marx contava com profissionais que o auxiliavam nas obras de seu escritório, como é o caso de Bolonha e a Fonte Andrade Júnior no Barreiro de Araxá.

Roberto Burle Marx, nascido em 1909, na cidade de São Paulo, e radicado no Rio de Janeiro, estudou pintura na Alemanha durante sua estadia no país, motivada por um problema de saúde. Voltou para o Brasil em 1930. Devido às influências artísticas trazidas da Europa, ingressa no curso de Belas Artes da Universidade Federal do Rio de Janeiro, fazendo seu primeiro projeto paisagístico de linhas modernas em 1932. O projeto era um jardim para a Residência da Família Schwartz, com projeto arquitetônico de Gregório Warchavchik e Lucio Costa, este último, vizinho de Burle Marx.

\footnotetext{
${ }^{35}$ Ver mais sobre a biografia de Francisco Bolonha em: MACEDO, O. L. C. Francisco Bolonha; ofício da modernidade. Dissertação (Mestrado em Arquitetura e urbanismo) - EESC - USP, São Carlos, 2003.
} 
Seu contato com amigos e professores como Lucio Costa, Leo Putz e Cândido Portinari o introduziu ao pensamento moderno, fazendo com que na década de 1940 se filiasse permanentemente, deixando para traz os projetos ainda de concepções acadêmicas da Beux-Arts. Depois do falecimento de Burle Marx, em 1994, a Burle Marx \& Cia Ltda passou a ser dirigida pelo arquiteto, companheiro de trabalho e amigo, Haruyoshi Ono.

Enquanto vivo, Roberto Burle Marx primava pela perpetuação de seus conhecimentos, assim como da necessidade de tê-los. Disseminava suas ideias, das quais via o jardim como um lugar onde se estabelece uma relação especial com a natureza, uma coexistência pacífica entre as várias espécies, um lugar de respeito pelo outro, uma vez sendo esse um espaço público, um instrumento de prazer e um meio de educação. Das características deixadas de seus projetos, destaca-se a valorização da beleza dos elementos nativos da flora brasileira, sendo ele o responsável pela introdução do paisagismo como parte integrante do projeto arquitetônico e urbanístico.

O convite para o projeto paisagístico do Parque da Estância do Barreiro veio quando Burle Marx ainda trabalhava no projeto paisagístico da Pampulha, no início da década de 1940 (PORTO, 2005), obra com a qual a Fonte de Bolonha dialoga diretamente. O Cassino, a Casa de Baile e o late Clube foram projetados por Oscar Niemeyer para o conjunto da Pampulha na capital mineira, sob a gestão de Juscelino Kubitschek, prefeito de Belo Horizonte entre 1940 e 1945. Contexto este em que Minas Gerais se favorecia com as mediações econômicas feitas no período do Estado Novo, onde foram construídos conjuntos públicos de grandes proporções como a Pampulha e a Estância do Barreiro de Araxá.

Minas Gerais ostentava uma economia pujante do período do Estado Novo (1937-1945), favorecida pelo bom trânsito político- 
financeiro do seu interventor Benedito Valadares, junto ao governo de Getúlio Vargas (1883-1954). Sua construção civil dinamiza-se sob a ação estatal. Havia importantes linhas de crédito da União que mantinham a realização de edifícios públicos e intervenções urbanas para modernizar e reequipar a capital e cidades do interior. Belo Horizonte e Araxá recebiam obras públicas de vulto e inauditas em outras partes do país naqueles anos, como, respectivamente, a construção de Pampulha e do Grande Hotel de Araxá. (DOURADO, 2000, p.91)

A iniciativa arquitetônico-paisagística do governador Benedito Valadares para o Parque do Barreiro de Araxá, figurou entre os maiores empreendimentos estatais em andamento no Brasil naquele momento. Foi divulgado, na época, como o maior complexo hidrotermal da América Latina, sendo comparado aos modelos europeus, embora haja nessa afirmação um caráter propagandístico. Construído entre 1930 e $1940^{36}$, figurou como o empreendimento de maior vulto dirigido à uma estância brasileira, envolvendo recursos estatais e profissionais renomados. (PORTO, 2005)

Araxá é uma cidade que cresceu em torno de seu potencial turístico e da pecuária, atividade esta que prosperou a partir do final do século XVIII quando as águas do Barreiro também começaram a ser utilizadas pelos criadores de gado, que complementavam a alimentação do rebanho com as águas salitradas do Barreiro, substituindo o sal extraído do mar que precisava ser comprado do Rio de Janeiro. (PORTO, 2005)

Para atender a atividade turística, foram construídos em Araxá estabelecimentos para lazer e hospedagem, como os cine-teatros, e os hotéis, muitos, seguindo grandes proporções arquitetônicas, variando entre os estilos

\footnotetext{
${ }^{36}$ Segundo Porto (2005), embora o parque da estância, como se conhece atualmente, tivesse sido construído nesse período, as fontes araxaenses já eram usadas com fins medicinais desde o início do século XX. A nova obra viria remodelar as antigas e modestas casas de banho já existentes no local. Anterior ao paisagismo de Burle Marx, eram de Reynaldo Dierberger os jardins da antiga estância, elaborados por volta da década de 1920. Dierbeger tinha uma clientela composta por vários membros da elite paulistana, tendo projetado os jardins da do Museu do Ipiranga em São Paulo. dentre vários outros.
} 
neoclássico, eclético e art déco. Já em 1937, “Araxá contava com vinte e um locais de hospedagem e aparecia como a quarta cidade mineira em número de estabelecimentos hoteleiros, sendo superada apenas por Belo Horizonte, Poços de Caldas e Juíz de Fora." (CONTINENTINO, 1937 apud PORTO, 2005)

Para a nova estância, estava previsto a criação de um parque, na área central da região de Araxá já conhecida como "barreiro", a qual deveria ser urbanizada, e onde estariam localizados o Grande Hotel, as termas, o cassino, as fontes e os demais equipamentos de recreação e esportes necessários para o funcionamento do Balneário. ${ }^{37}$ Luiz Signorelli, Francisco Bolonha e Raphael Hardy Filho são os arquitetos envolvidos nas obras, porém é Signorelli o arquiteto responsável pelos projetos de grande parte dos prédios do Barreiro. (PORTO, 2005)

10. Fonte Dona Beja. Fonte: Porto, 2005.

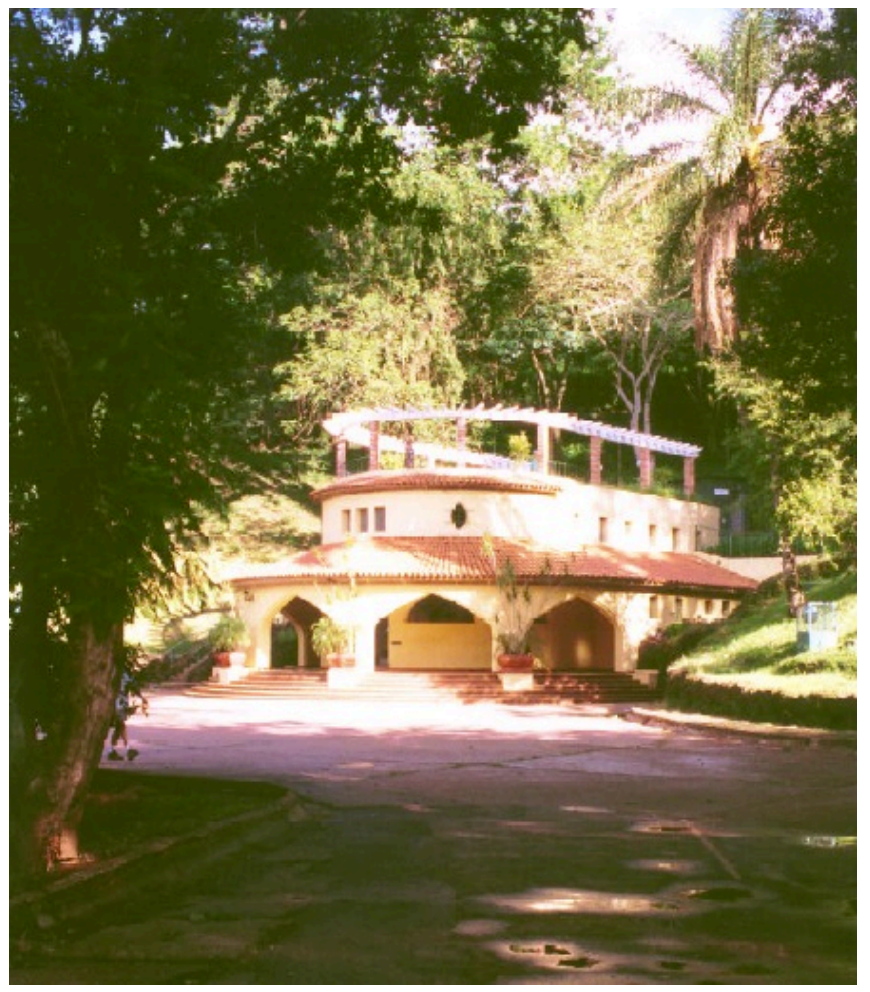

\footnotetext{
${ }^{37}$ Para o plano urbano do Barreiro, assim como a descrição dos edifícios e demais equipamentos,
procurar: PORTO, Daniele Resende. O Barreiro de Araxá: Projetos para uma estância hidromineral

${ }^{37}$ Para o plano urbano do Barreiro, assim como a descrição dos edifícios e demais equipamentos,
procurar: PORTO, Daniele Resende. O Barreiro de Araxá: Projetos para uma estância hidromineral em Minas Gerais. Dissertação de Mestrado, Escola de Engenharia de São Carlos, Universidade de São Paulo, São Carlos, 2005.
} 
Assim como Bolonha, é dentro da Comissão de Obras do Barreiro, desde 1938, que Raphael Hardy Filho inicia sua carreira. Trabalhava no escritório de Signorelli, que Ihe repassou o projeto para a Fonte Dona Beja, sob sua orientação. Diferente da fonte de Bolonha, Hardy projeta um edifício em concordância estilística com os outros projetos de Signorelli para o parque. Mas as ideias em seu projeto para as Instalações Industriais da Fertiza, em Araxá, na década de 1950, são totalmente vinculadas ao pensamento moderno. Os edifícios projetados por Hardy para as Instalações Industriais da Fertiza formaram o primeiro conjunto moderno de grandes dimensões de Araxá e do Triângulo Mineiro e Alto Paranaíba, como veremos adiante.

No Barreiro, Burle Marx trabalha em conjunto com o botânico Henrique Lahmeyer de Mello Barreto - com quem trava uma parceria importante em vários projetos - e continua desenvolvendo as ideias já iniciadas no Ministério da Educação e Saúde e Pampulha, dando destaque aos aspectos regionais em oposição à valorização de elementos exóticos, característicos da linha acadêmica, sempre na busca por uma arte nacional. Para o projeto, Burle Marx e o botânico Mello Barreto realizaram expedições para a coleta de plantas em algumas regiões do estado de Minas Gerais como as da Serra da Piedade, do Curral e do Cipó, Lagoa Santa e Sete Lagoas, conseguindo montar um conjunto de espécies autóctones que não se encontravam no comércio, a fim de reproduzir as várias zonas fitogeográficas da região. (ADAMS, 1991) Sobre o botânico, Burle Marx sublinhava recorrentemente:

Ele me ensinou a observar que as plantas não vivem isoladas, mas em associações, que têm sua lógica própria e sua beleza. Aprendi que é importante conhecer seu habitat natural, antes de querer utilizá-las em jardins. (BURLE MARX, 1975 apud DOURADO, 2000) 
Pelo uso da vegetação da região, os jardins do Barreiro afirmavam as riquezas locais, sendo recorrente esse tipo de justificativa nos memoriais do projeto, nos quais Burle Marx e Mello Barreto criticavam as referências academicistas, muito usadas nos jardins brasileiros daquela época, pautadas em padrões internacionais. Segundo Mello Barreto, havia uma noção de Parque Didático no Barreiro de Araxá, inspirada em Engler, que agrupou no Jardim Botânico de Dahlen, na Alemanha, plantas das regiões do Cárpato, dos Alpes, e dos Apeninos (OLIVEIRA, 1992), produzindo um mostruário que dificilmente um viajante comum poderia presenciar.

O plano paisagístico para o parque foi organizado em vinte e cinco seções, compostas por grupos vegetais de diferentes regiões do estado de Minas Gerais e coletados durante as expedições com o objetivo de reproduzir um mostruário da variada flora do estado. Desse modo, o parque contava com grupos de vegetais específicos, setorizados por todo o parque, como as plantas perenes e os representantes legítimos da flora serrana situados na alameda de entrada e as plantas hidrófilas nas áreas de brejo. Ao longo da Avenida do Contorno, a qual delimita o parque, é possível perceber os agrupamentos característicos da canga da Serra do Curral, Serra do Cipó, além de elementos da caatinga, roseirais, palmeiras, uma ampla zona de semi-xerófitas, com ipês, cássias, primaveras e quaresmeiras de cores variadas, além de embaúbas, jacarandás, gameleiras, pindaíbas, fícus, jequitibás, tamboris, copaíbas e paineiras, e ainda presente, um bosque com árvores de grande porte circundando toda a extremidade do parque. Neste projeto, o paisagista teve a preocupação em selecionar plantas com períodos de floração diferentes de modo que o conjunto apresentasse pontos floridos e de cor durante todo o ano. Também foram usadas espécies com características cromáticas variadas a fim de se explorar os contrastes entre as cores das flores, frutos, folhas e caules. Dos vinte e cinco setores propostos por Burle Marx, apenas 21 foram executados. (PORTO, 2005) 


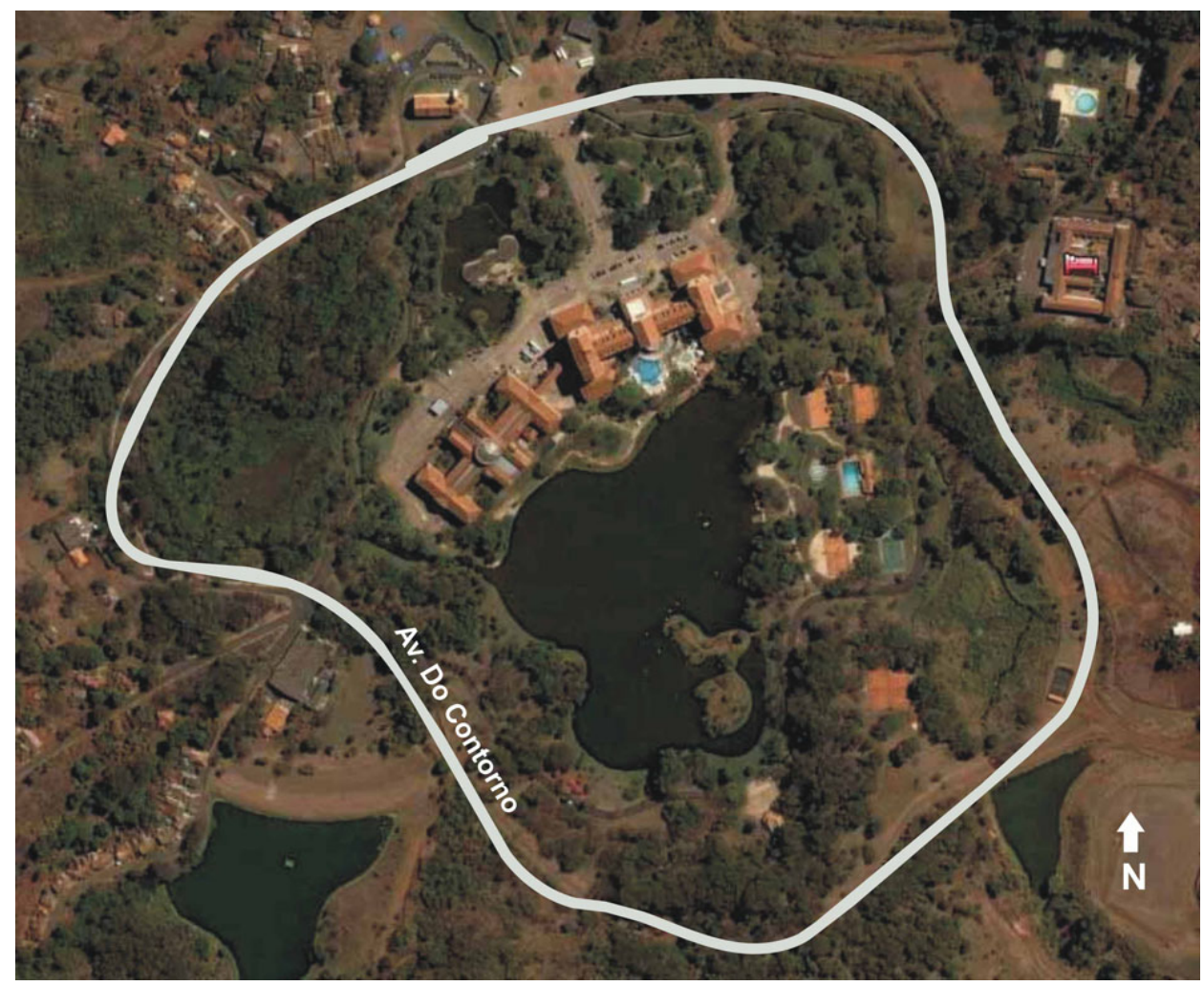

11. Parque da Estância do Barreiro. Imagem Aérea. Fonte: elaborado pela autora. NUTHAUFAUeD / UFU.

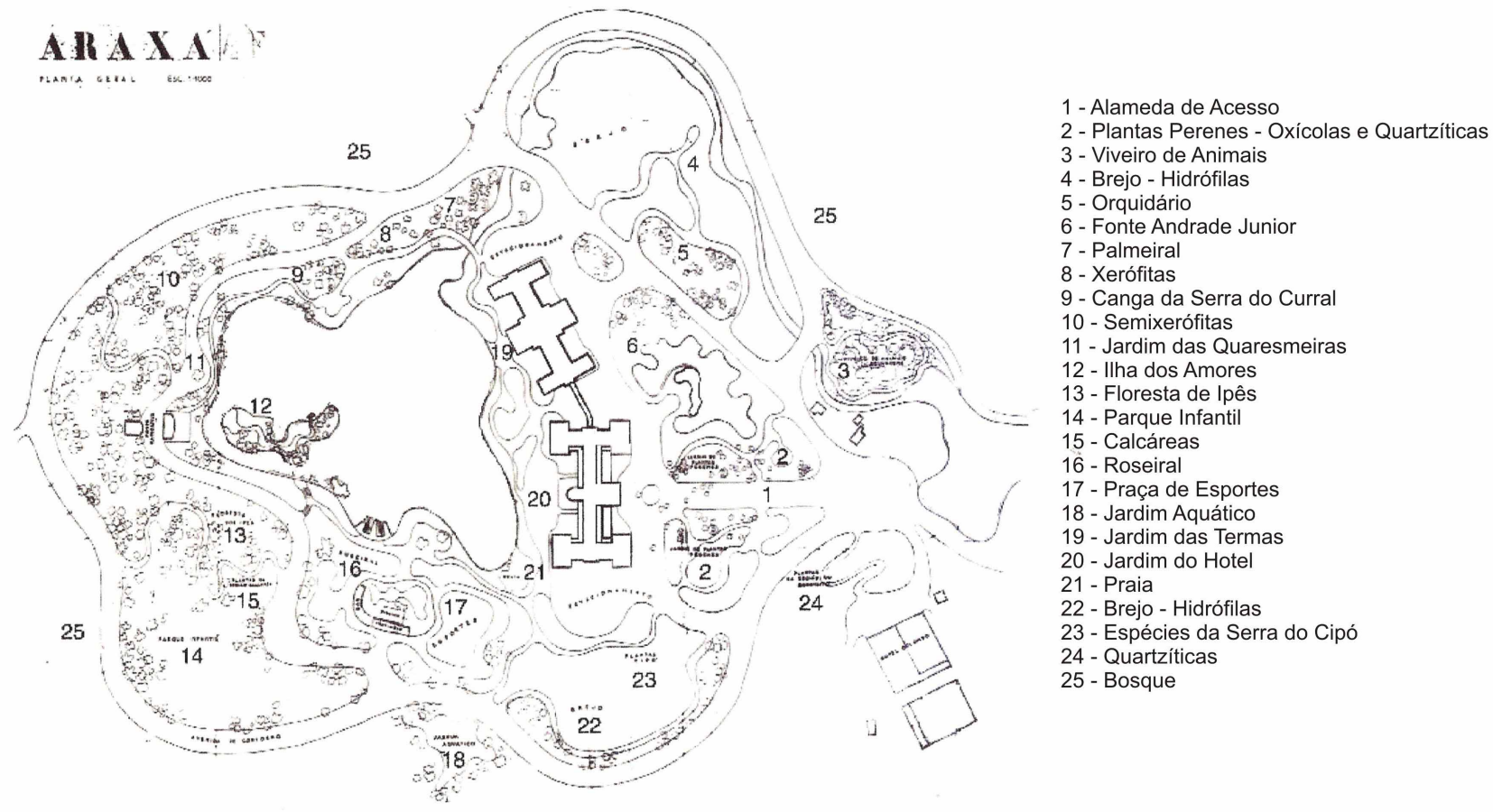

12. Parque da Estância do Barreiro. Implantação. Fonte: PORTO, 2005. 


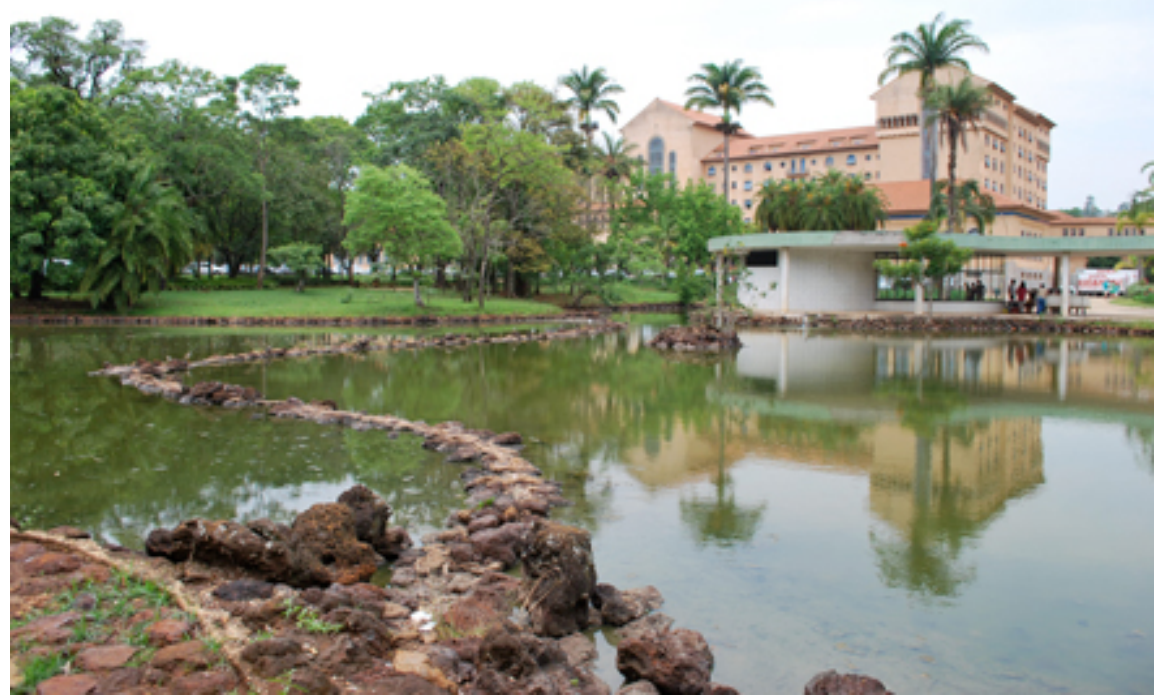

14. Conjunto Paisagístico de Burle Marx, Fonte Andrade Júnior e Grande Hotel ao fundo. Fonte: NUTHAU-FAUeD / UFU.

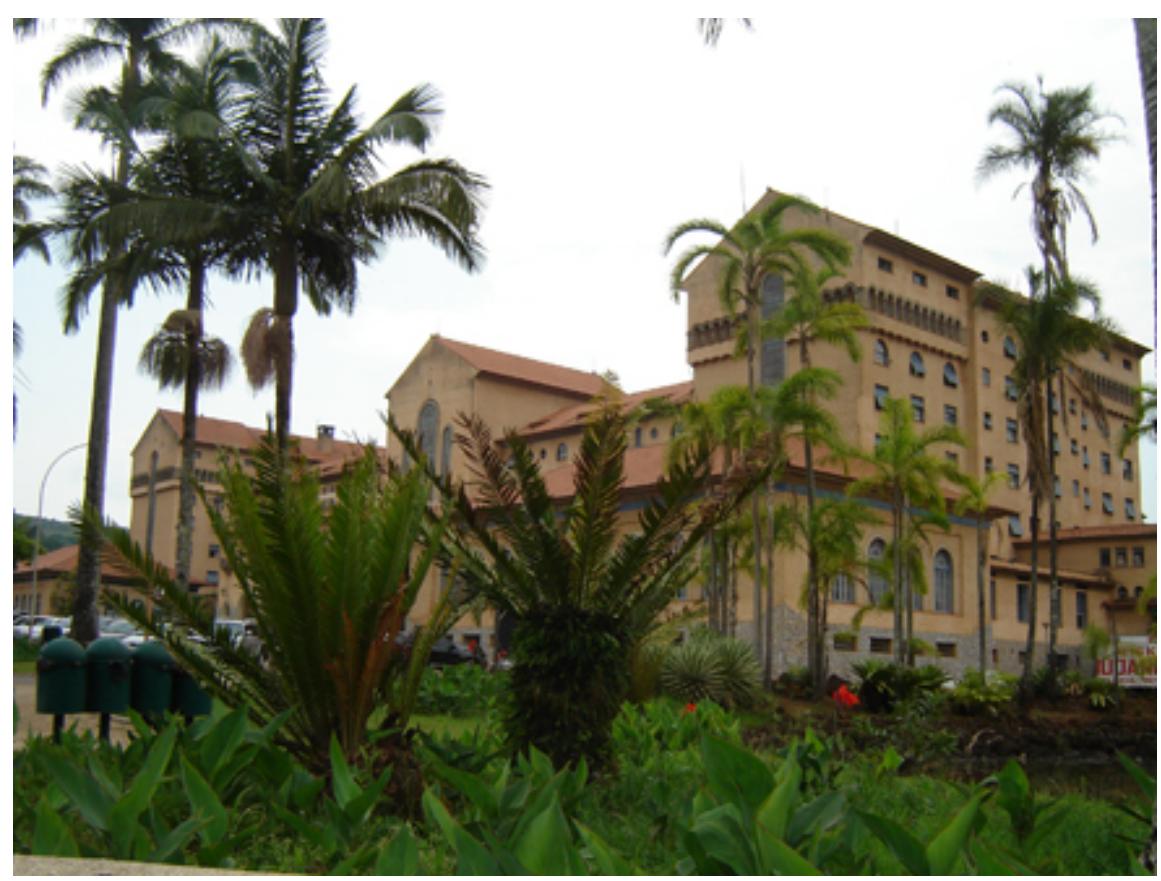

15. Parque da Estância do Barreiro. Grande Hotel e Termas. Fonte: NUTHAU-FAUeD / UFU. 
16. Parque da Estância do Barreiro. Parte da Fachada Frontal do Grande Hotel. Fonte: PORTO, 2005.

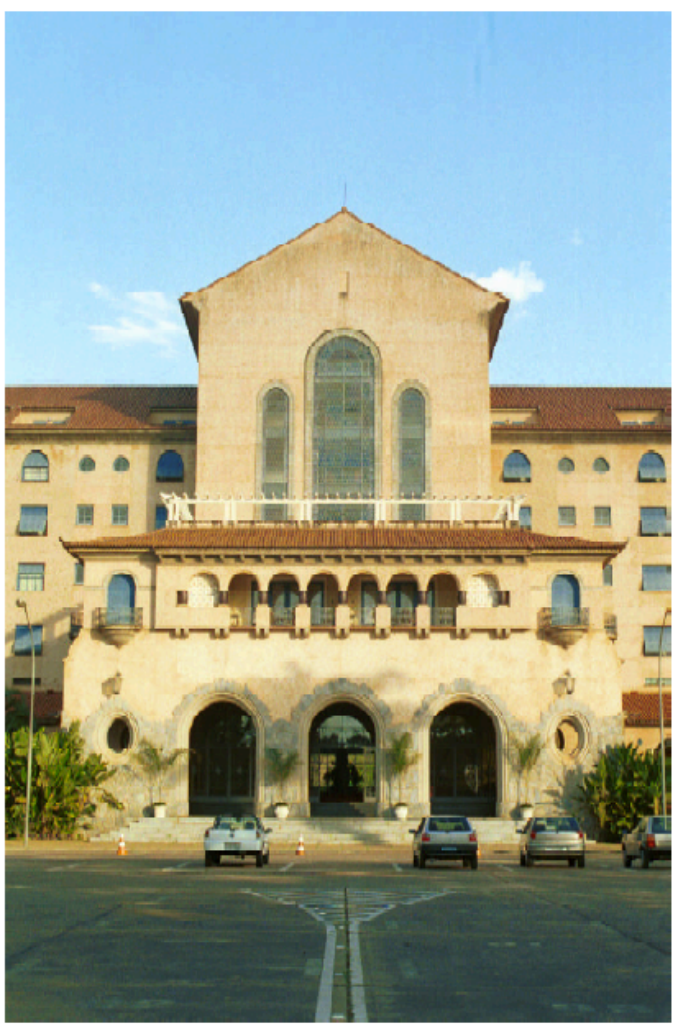

A Fonte Andrade Júnior está localizada às margens de um lago desenhado por Burle Marx, defronte para o prédio do Grande Hotel e Termas. Para os jardins no entorno da fonte, o paisagista emprega espécies com cores variadas, explorando os contrates entre as folhas, flores, frutos e caules da vegetação. Para a fonte, Bolonha desenha um edifício totalmente diferente das concepções neoclássicas dos outros edifícios projetados para o parque, como o Grande Hotel e Termas, em estilo eclético, de Luiz Signorelli ${ }^{38}$, arquiteto que lecionou por vários anos na EABH (Escola de Arquitetura de Belo Horizonte).

Em sintonia com o projeto paisagístico de Burle Marx, Bolonha desenha um edifício de linhas sinuosas, acompanhando as curvas do lago desenhado pelo paisagista. Segundo projeto original, o prédio em concreto armado abriga

\footnotetext{
${ }^{38}$ Luiz Signorelli, mineiro, arquiteto e pintor. Formou-se pela Escola Nacional de Belas Artes do Rio de Janeiro em 1925, participou do Salão Nacional de Belas Artes em 1923 e 1926. Foi fundador e organizador e primeiro diretor da EABH, atual Escola de Arquitetura da UFMG. Em 1928, fixa residência em Belo Horizonte e atua em inúmeros projetos na capital e no estado. Foi professor de Grandes Composições de Arquitetura.
} 
dois pavilhões cobertos por uma laje curva, sustentada por pilares revestidos em mármore travertino. Os pavilhões, um em cada extremidade, estão rebaixados em relação ao conjunto e possuem fechamento em vidro e esquadrias de ferro fixas, abertas na parte mais alta, de maneira a oferecer proteção aos ventos dominantes. Neles estão localizados os oito bebedouros com água mineralizada. Em um dos pavilhões estão expostos os fósseis encontrados na região durante as escavações das obras do complexo, os quais explicam os motivos de animais pré-históricos desenhados nos azulejos das rampas de acesso aos bebedouros e na paginação de piso em pedra portuguesa preta e branca, ambos desenhados por Burle Marx.

Caminhando pela fonte, percebe-se a preocupação de Bolonha em presentear o usuário com experiências de enquadramento da paisagem circundante, pela sucessão dos pilares, dos cheios e vazios e a diferença dos níveis entre o passeio e os pavilhões de bebedouros, estes situados em uma cota rebaixada. A sinuosidade das linhas do desenho de Bolonha acompanha a mesma sinuosidade dos jardins de Burle Marx, formando um conjunto harmonioso, inclusive com a arquitetura circundante. De fato, a harmonia existente entre o projeto moderno de Bolonha e o eclético de Signorelli se deve, sobretudo, à harmonia existente a priori entre o projeto paisagístico de Burle Marx e o projeto para a Fonte Andrade Júnior, de Bolonha.

Atualmente, a fonte já apresenta algumas modificações. A laje plana, antes revestida em mármore travertino, agora tem revestimento em pastilha cerâmica na cor verde, sendo levantada uma pequena platibanda, onde foram colocadas calhas, e o plano envidraçado que fechava o pavilhão na fachada norte foi retirado. Alterações que também modificam, em certo sentido, as percepções do usuário. O mármore travertivo, que revestia a laje plana, servia como contraste cromático entre a edificação e a vegetação circundante, e o 
plano envidraçado, não só tornava o local, um abrigo, por conta do fechamento, como emoldurava a paisagem além do lago.

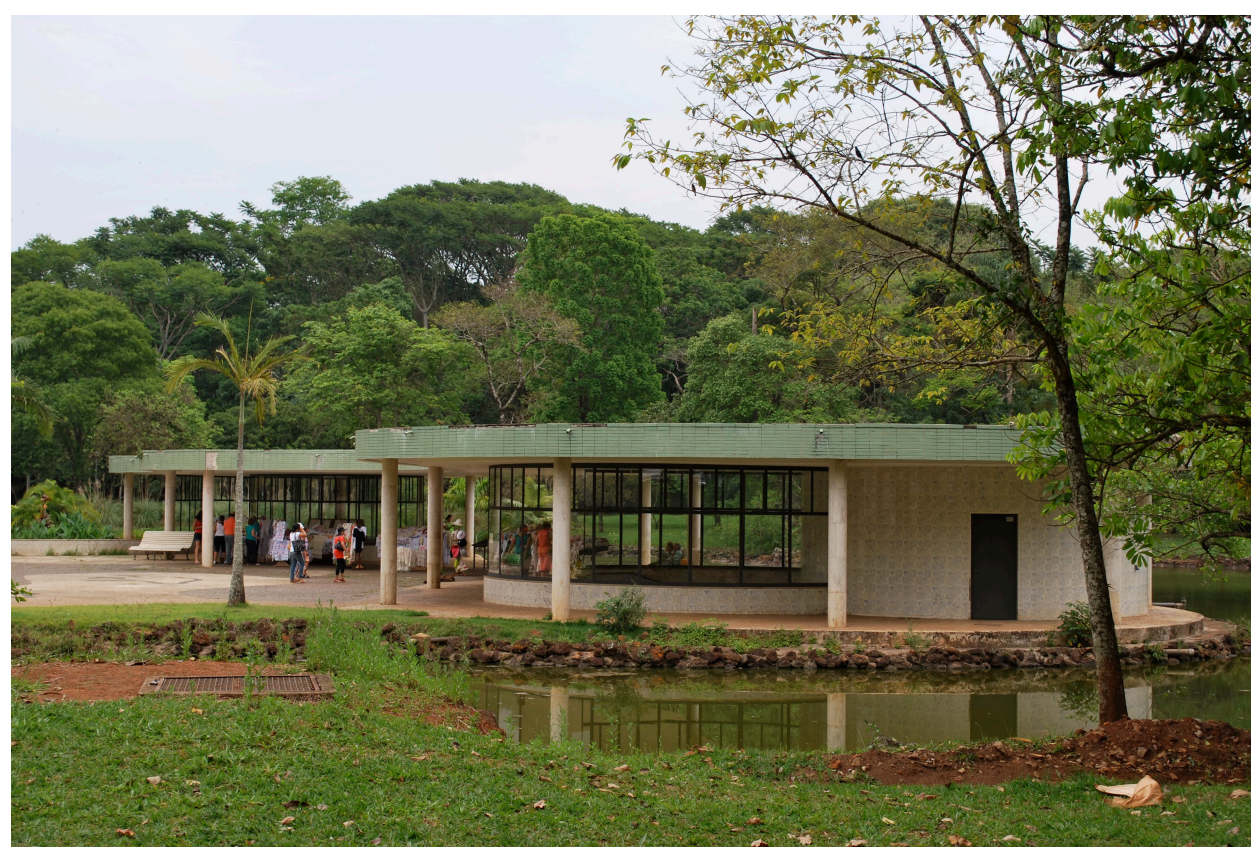

17. Fonte Andrade Júnior. Fonte: NUTHAU-FAUeD. / UFU.

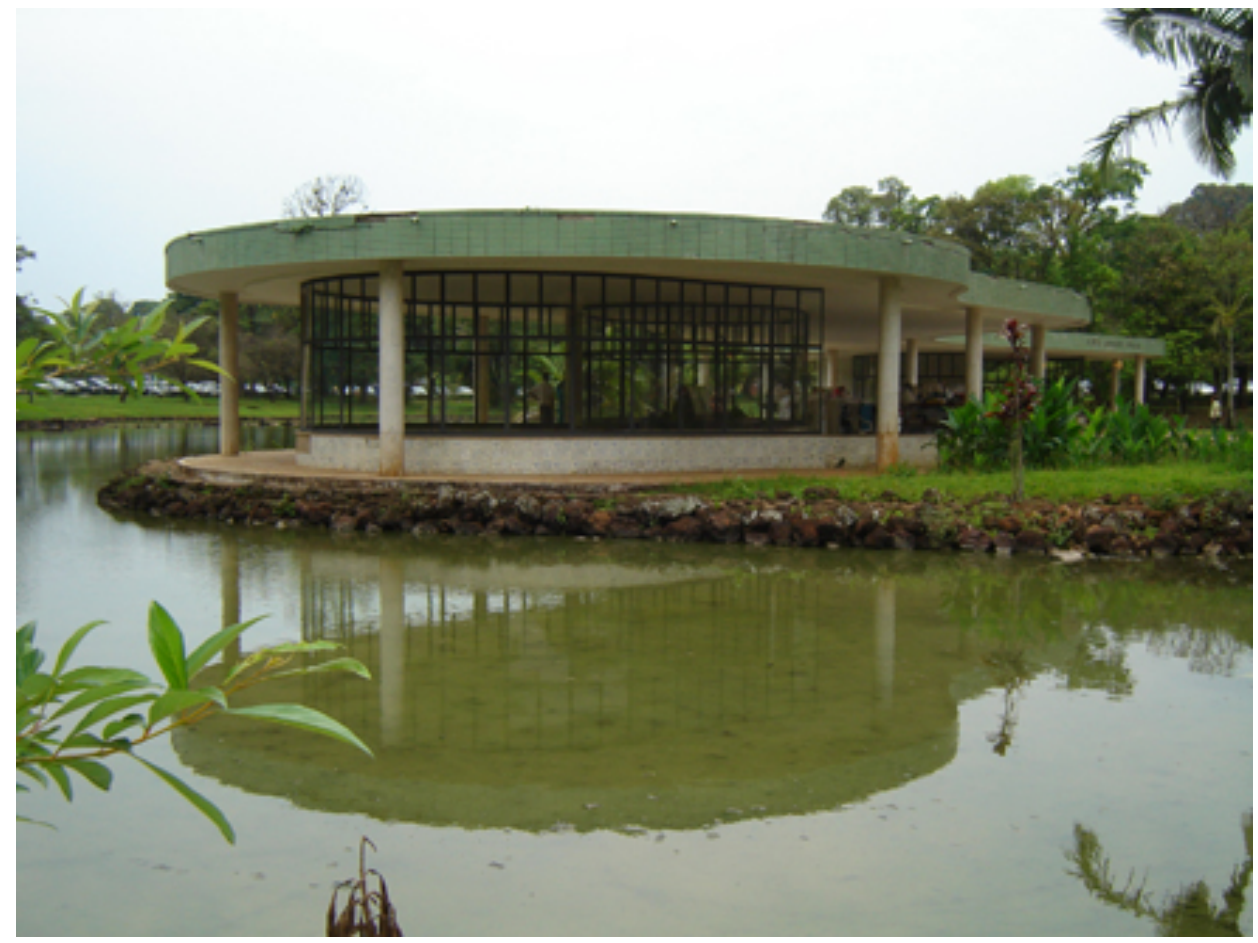

18. Fonte Andrade Júnior. Fonte: NUTHAU-FAUeD. / UFU. 


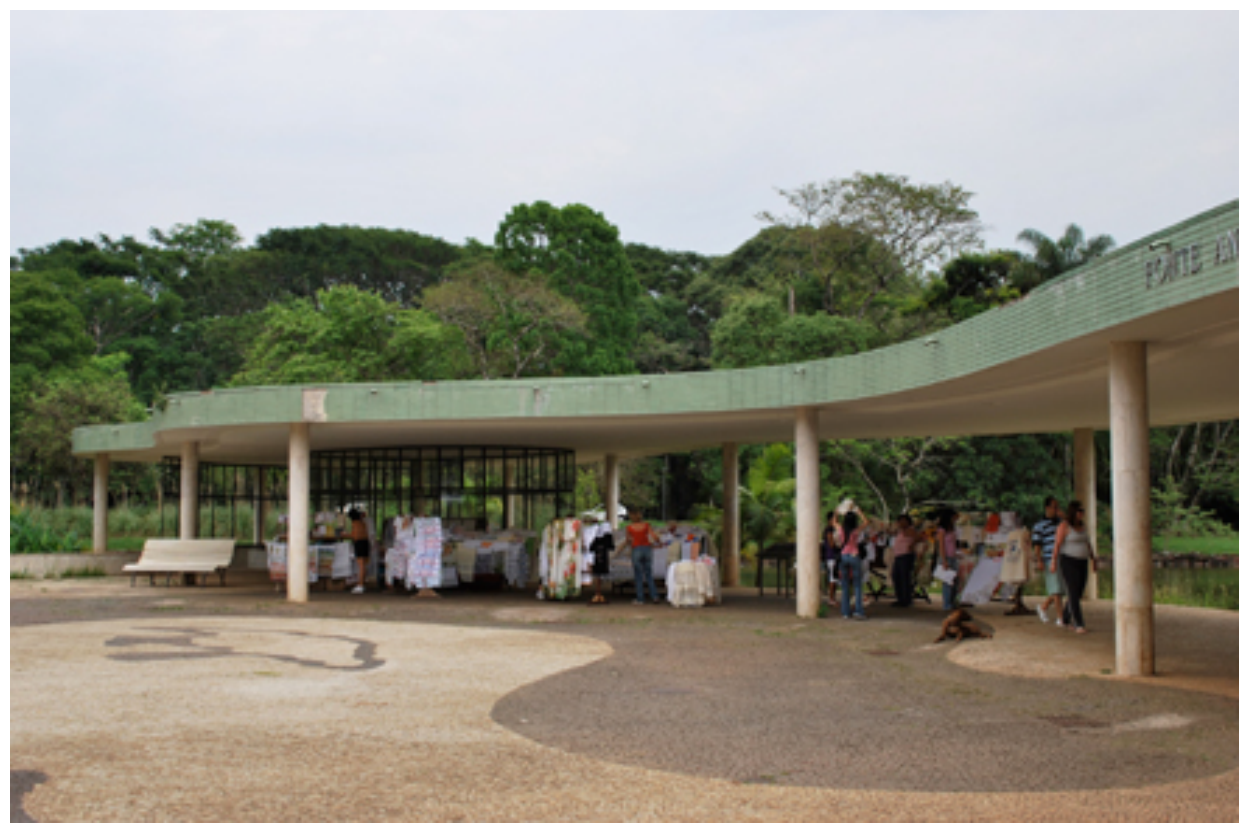

19. Fonte Andrade Júnior. Fonte: NUTHAU-FAUeD / UFU.

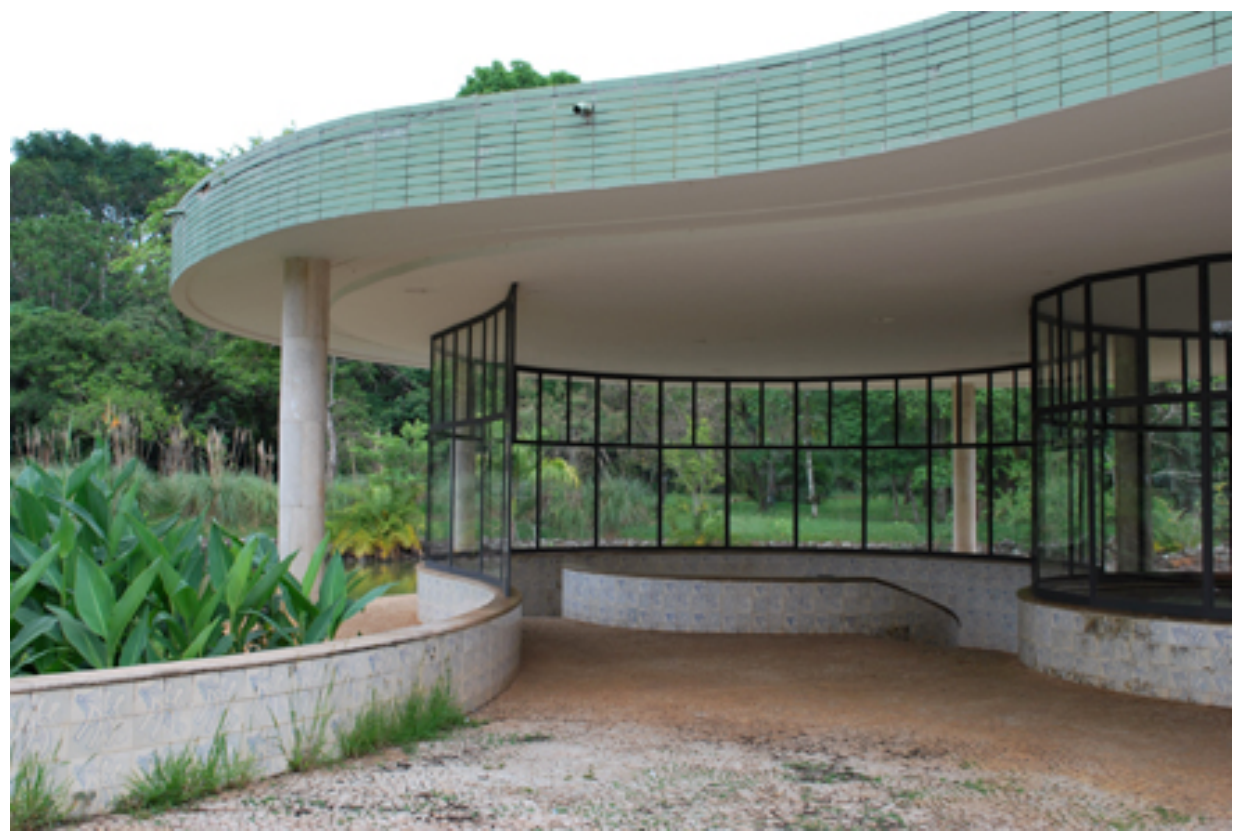

20. Fonte Andrade Júnior. Pavilhão. Fonte: NUTHAU-FAUeD / UFU. 


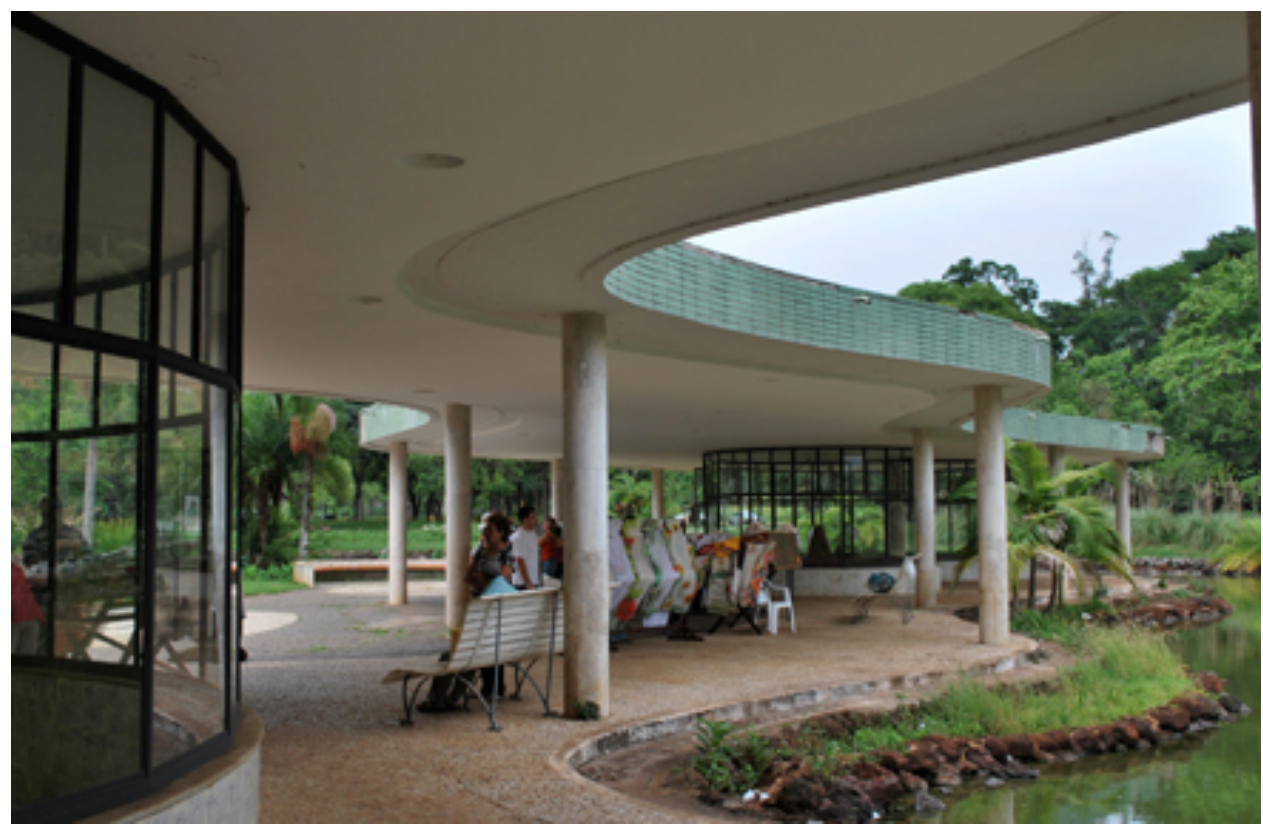

21. Fonte Andrade Júnior. Fonte: NUTHAU-FAUeD / UFU.

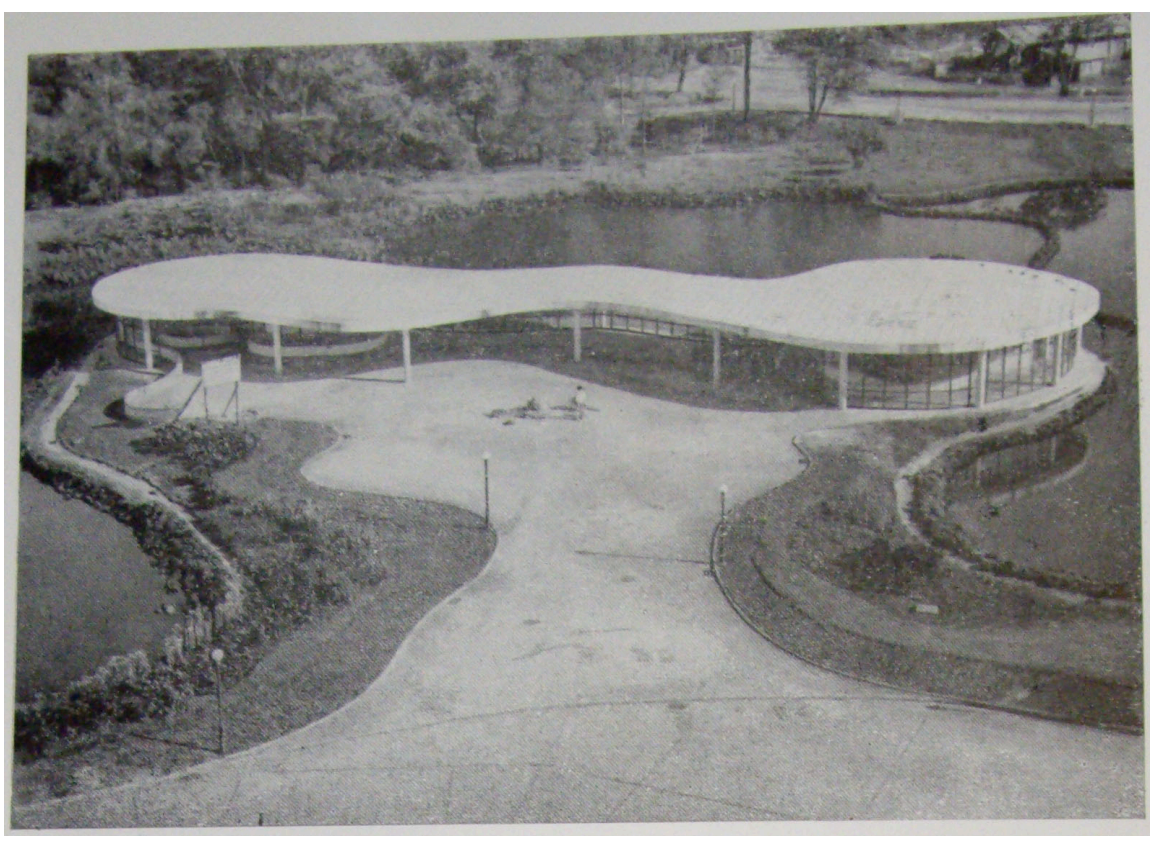

22. Fonte Andrade Júnior. Ano 1948. Fonte: Revista Municipal de Engenharia, Numero 4 Outubro - Dezembro 1948, volume XV. NUTHAU-FAUeD / UFU. 


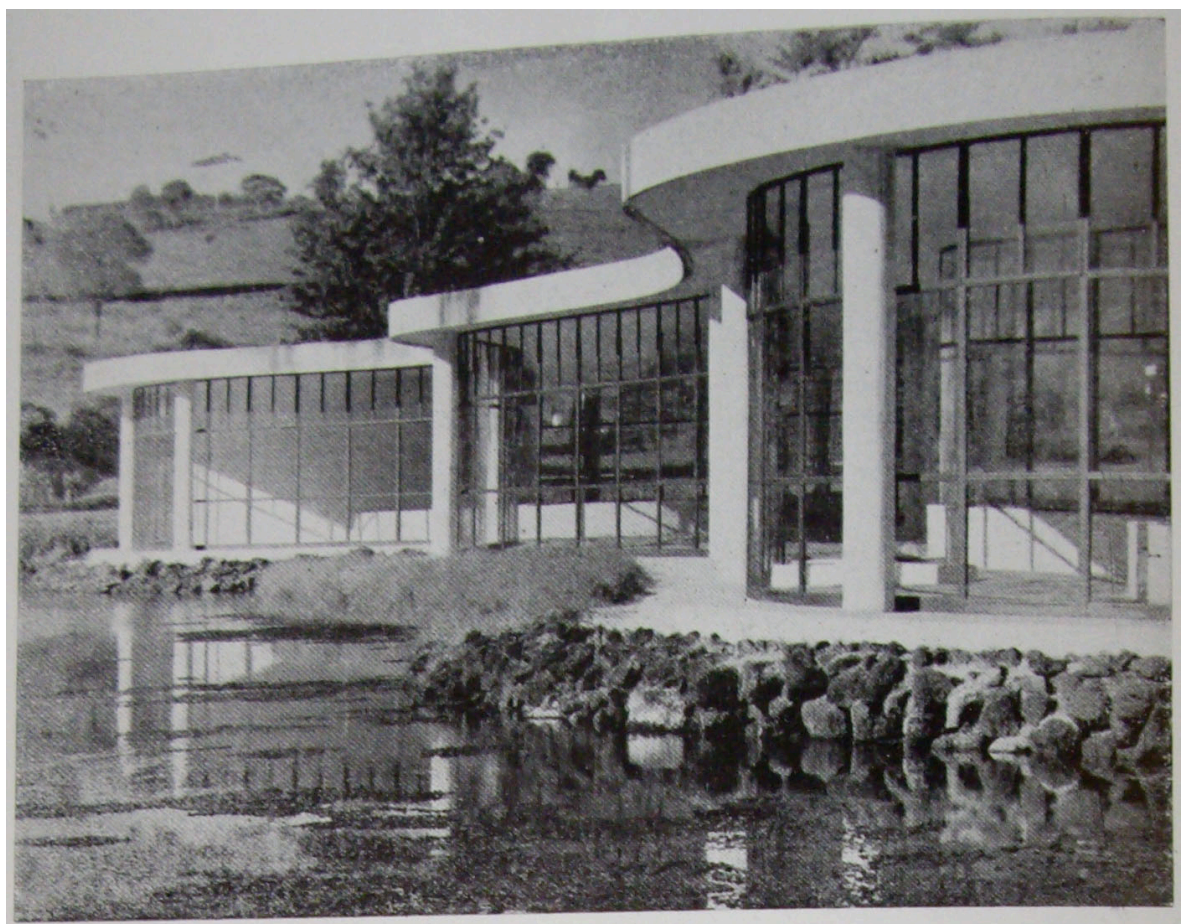

23. Fonte Andrade Júnior. Ano 1948. Fonte: Revista Municipal de Engenharia, Numero 4 Outubro - Dezembro 1948, volume XV. NUTHAU-FAUeD / UFU.

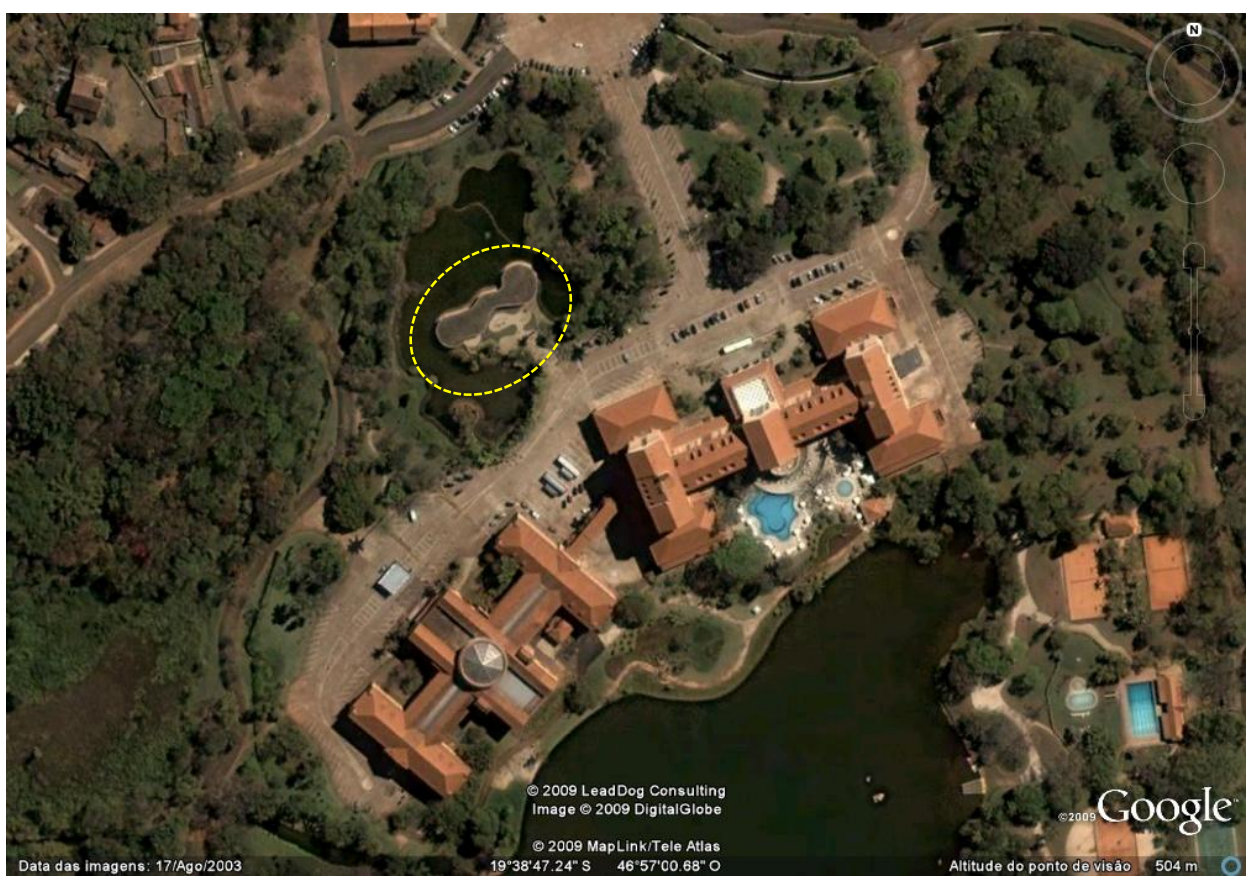

24. Fronte Andrade Júnior em destaque e Grande Hotel e Termas. Imagem Aérea. Fonte: Google Earth. NUTHAU-FAUeD / UFU. 


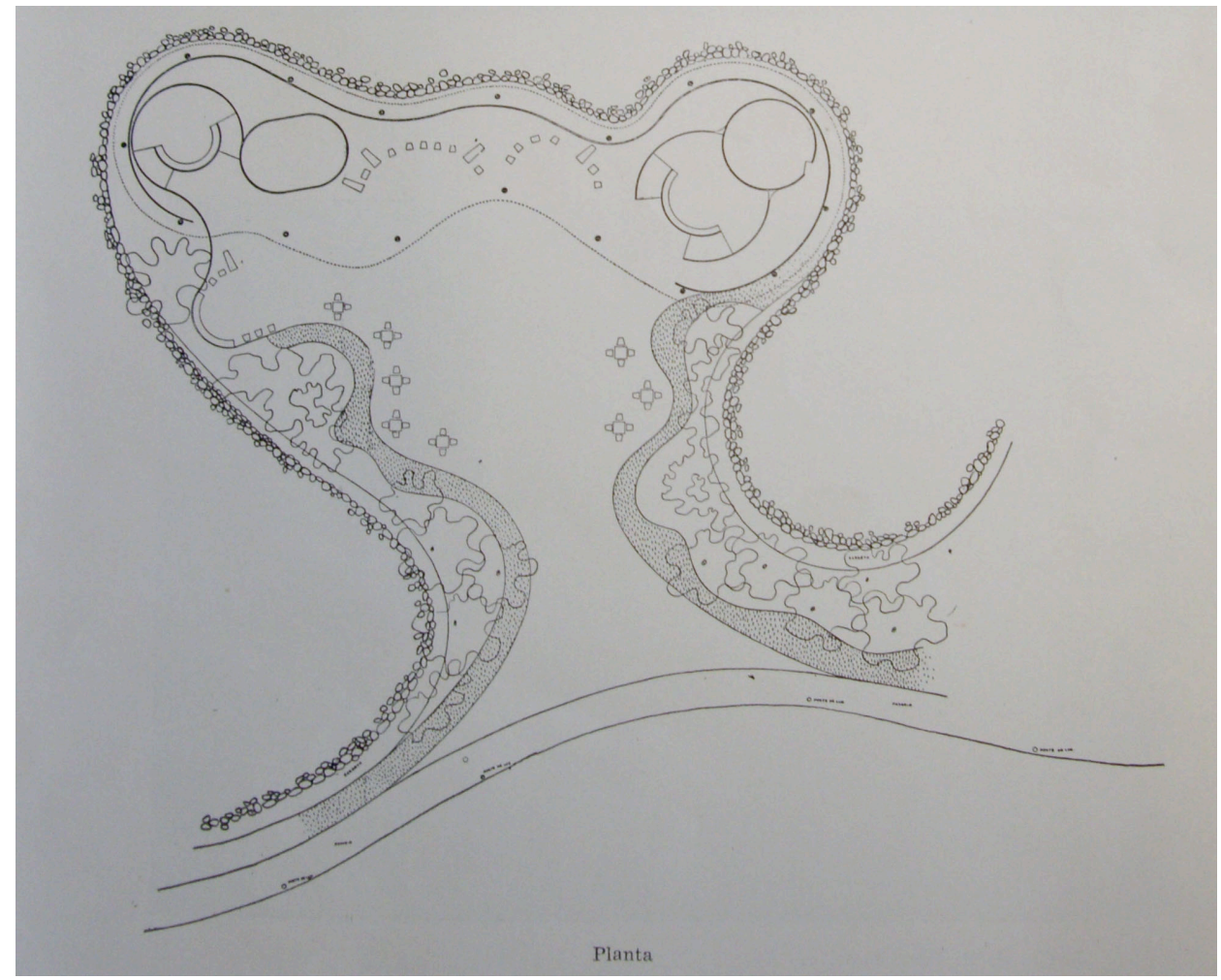

25. Fonte Andrade Júnior. Planta e paisagismo. Fonte: Revista Municipal de Engenharia, Numero 4 Outubro - Dezembro 1948, volume XV. NUTHAU-FAUeD / UFU.

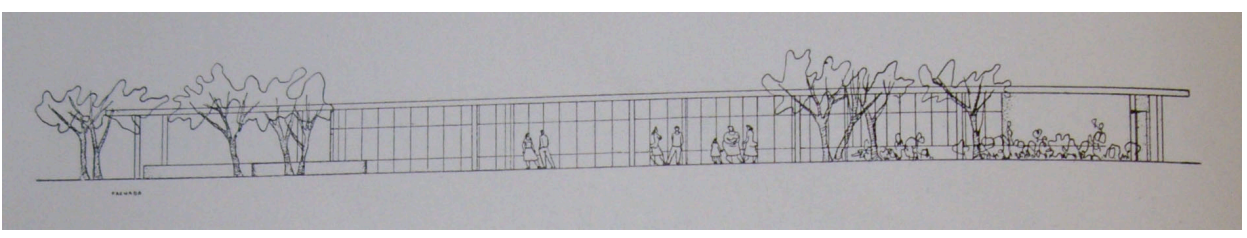

26. Fonte Andrade Júnior. Elevação. Fonte: Revista Municipal de Engenharia, Numero 4 Outubro - Dezembro 1948, volume XV. NUTHAU-FAUeD / UFU.

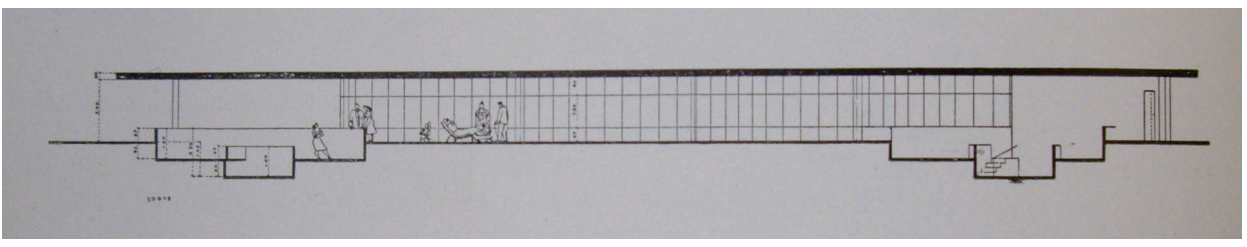

27. Fonte Andrade Júnior. Elevação. Fonte: Revista Municipal de Engenharia, Numero 4 Outubro - Dezembro 1948, volume XV. NUTHAU-FAUeD / UFU. 
Para a Praça de Esportes, Bolonha desenha um edifício com linhas mais retilíneas, dentro das novas concepções modernas para a arquitetura brasileira, porém ainda preocupado com a harmonia arquitetônica e paisagística do conjunto. A nova Praça de Esportes viria substituir a praça construída de acordo com projeto de Luiz Signorelli, seguindo as concepções ecléticas de seus outros edifícios para a estância. Essa substituição não foi feita e o projeto de Francisco Bolonha jamais foi executado. ${ }^{39}$

Basicamente o projeto de Bolonha para a Praça de Esportes manteria o programa da antiga praça, com áreas de recreação, quadras, piscinas e uma área para restaurante. No projeto, Bolonha tira partido da plasticidade das coberturas e da declividade do terreno. Na cota mais alta dispõe a área com restaurante, bar, chapelaria e um terraço, onde os turistas poderiam avistar o lago, as piscinas, quadras e jardins. Na cota mais baixa, distribui os vestiários e o atendimento médico.

Embora a cobertura seja contígua em todo edifício, Bolonha a desenha em três partes. Dois planos inclinados em cada extremidade, configurando volumes trapezoidais - o maior cobrindo o bloco do restaurante e um menor cobrindo o volume para o atendimento médico - interligados por um conjunto de abóbodas chatas dispostas em duas fileiras, entre a quais foram colocados dois pátios descobertos. A inclinação do plano que cobre o volume do restaurante acompanha o aclive do terreno até o terraço, onde está a cota mais alta do edifício. Com este artifício, Bolonha dialoga a plasticidade do seu desenho com a intenção do projeto: abrir a vista do turista colocando-o na cota onde teria visão privilegiada da paisagem circundante.

Percebe-se também no projeto de Bolonha, uma intenção clara em novamente afinar seu desenho com o paisagismo de Burle Marx, embora, perceba-se também um cuidado plástico em seu projeto, a fim de não extinguir

\footnotetext{
${ }^{39}$ Porto (2005) relata que existiram vários desentendimentos entre Luiz Signorelli e Burle Marx, cujas concepções arquitetônicas, muito constrastavam entre si.
} 
a harmonia do conjunto arquitetônico do balneário como um todo, embora, a diferença de concepções usadas por Bolonha e Signorelli sejam, por essência, contrastantes. O partido horizontal do projeto talvez indique um primeiro indício de tal preocupação. Bolonha não utiliza de formas monumentais, ou de uma verticalidade que marcaria com maior efeito o contraste do novo edifício no conjunto. $\mathrm{O}$ arco encontrado nas abóbodas chatas da cobertura central da nova Praça de Esportes é, por excelência, um elemento clássico e, em uma das elevações - onde é possível ver os volumes trapezoidais - o edifício fica próximo à uma simetria, embora nunca a atinja. Pode-se dizer, que estes elementos, configurados com medidas de proporção, dentro de um conceito ainda moderno, atenuaram o conflito de concepções entre o moderno de Bolonha e o eclético de Signorelli.

Na década de 1960, outros projetos modernos foram construídos nas proximidades da estância, como o Terminal Rodoviário e o Posto de Manutenção Automotiva, ambos projetos de Bellini dos Santos Filho, em 1964, e o Grupo Escolar do Barreiro, outro projeto de Raphael Hardy Filho na cidade. (PORTO, 2005)

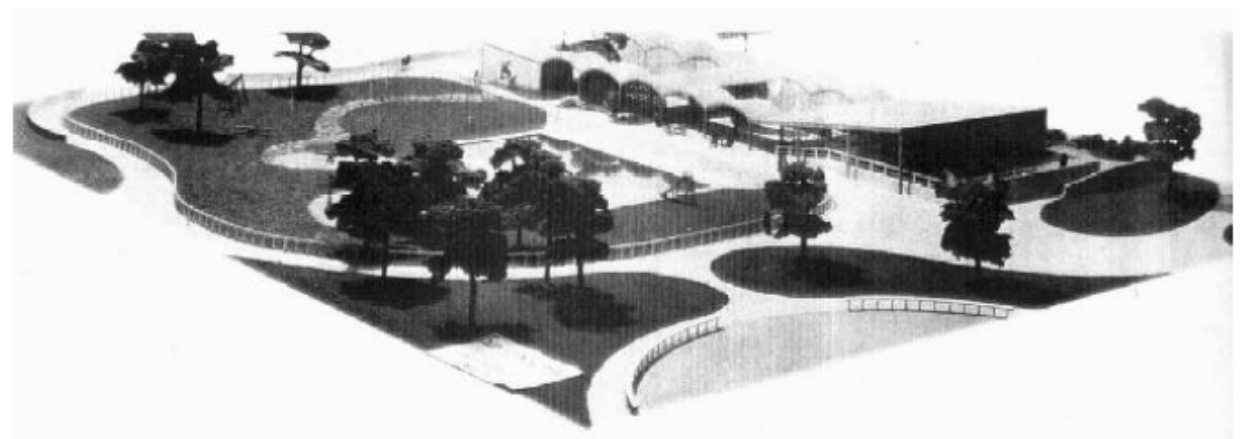

28. Praça de Esportes. Maquete. Fonte: Porto, 2005 


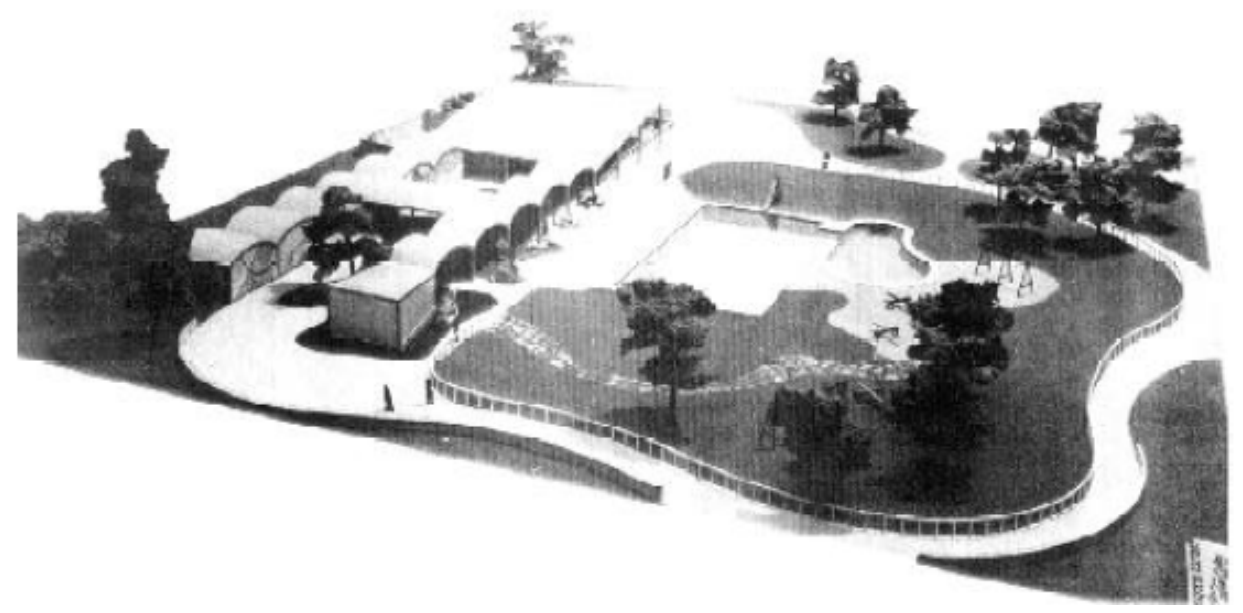

29. Praça de Esportes. Maquete. Fonte: Porto, 2005.

\footnotetext{
1 restaurante

2 terraço

3 living room

4 bar

5 chapelaria

6 cozinha

7 sanitarios e serviços

8 vestiarios
}

9 atendimento medico

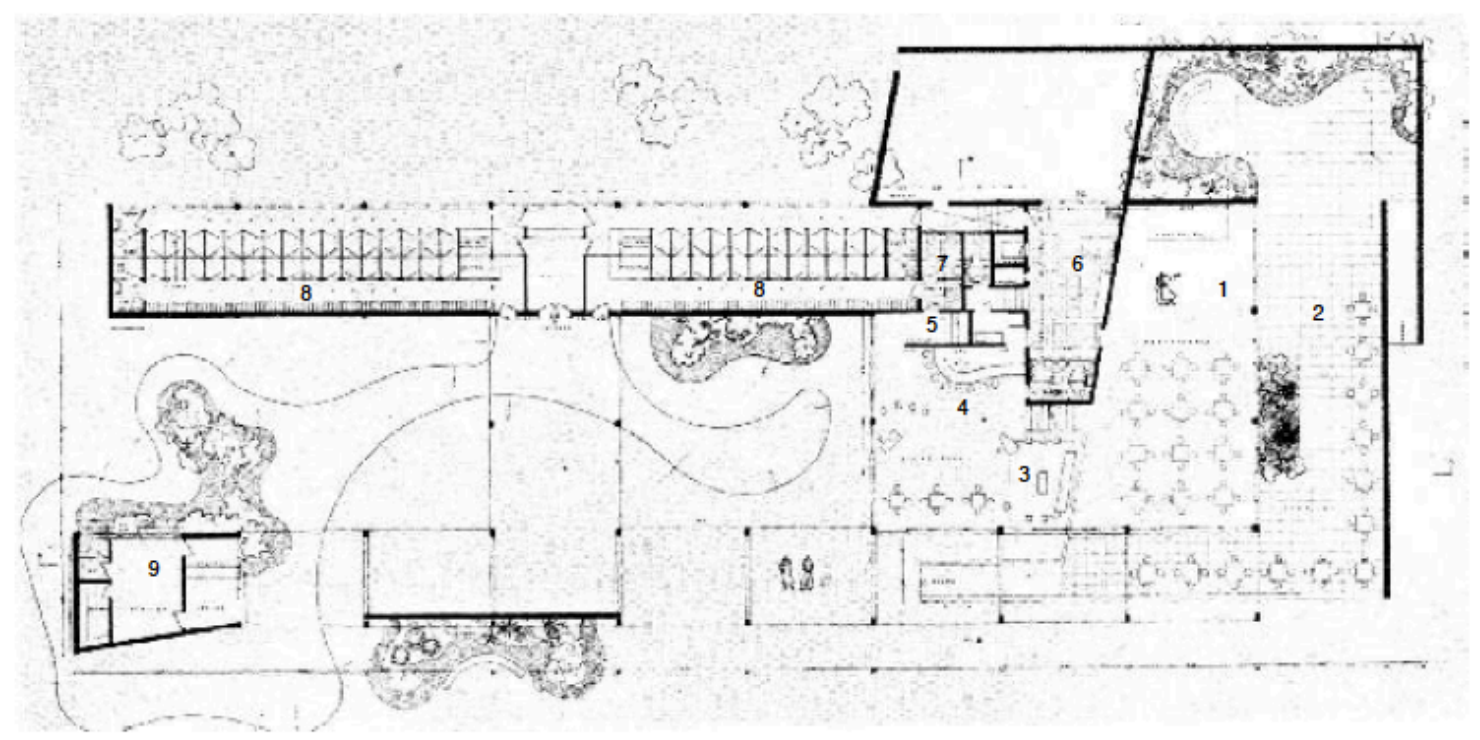

30. Praça de Esportes. Planta. Fonte: Porto, 2005. 

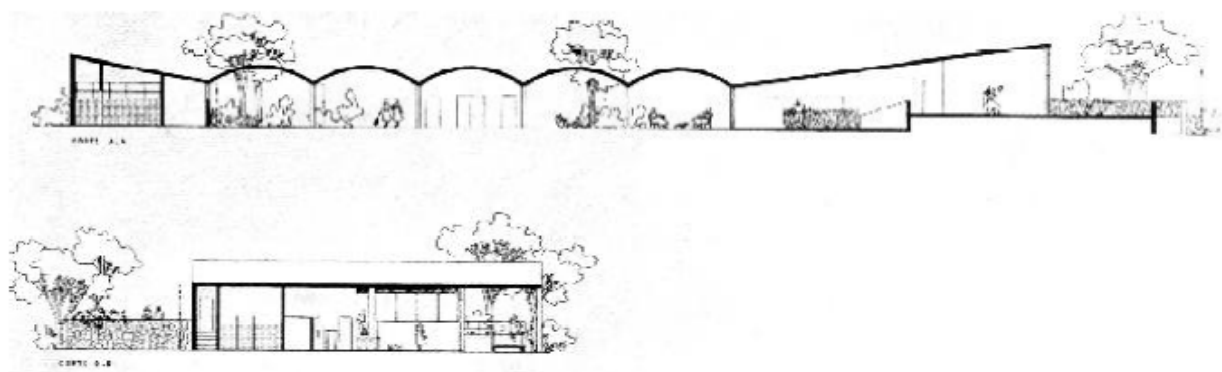

31. Praça de Esportes. Cortes. Fonte: Porto, 2005.
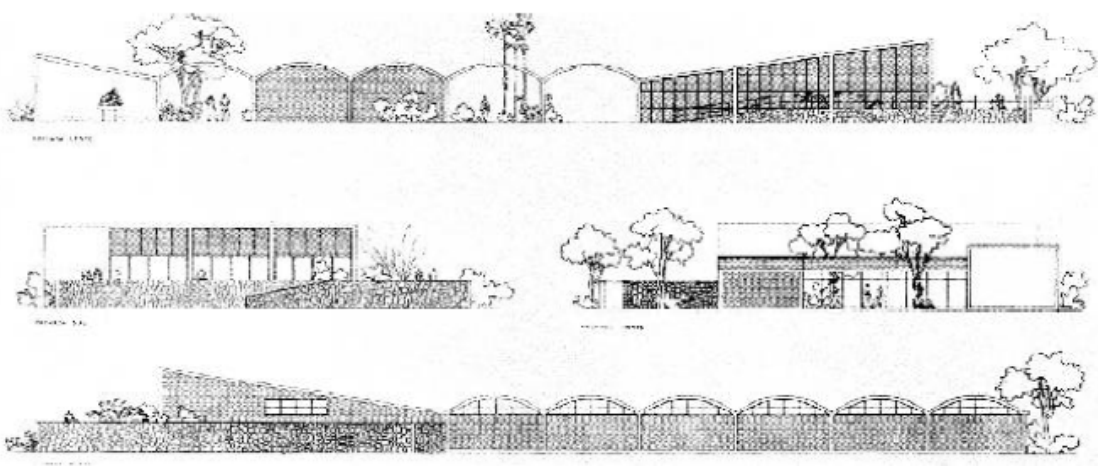

32. Praça de Esportes. Elevações. Fonte: Porto, 2005.

A proximidade temporal dos edifícios modernos para o Parque da Estância do Barreiro de Araxá e o conjunto de edifícios feitos para Pampulha em Belo Horizonte revelam diálogos de projeto também bastante próximos. Isto é visível principalmente no projeto de Bolonha para a Fonte Andrade Júnior, onde o arquiteto explora as mesmas potencialidades plásticas que Niemeyer, no uso do concreto armado, sobretudo para a forma curva. Assim como a Casa do Baile de Niemeyer, a fonte de Bolonha se estabelece como um vazio coberto por uma marquise sinuosa entre dois volumes sólidos, enquadrando a paisagem aquática vizinha.

Também, assim como no edifício para o late Clube da Pampulha, a Praça de Esportes de Bolonha configura-se por meio de dois volumes trapezoidais formados pelas coberturas planas. No edifício de Niemeyer, forma 
o teto borboleta, no de Bolonha, estão interligados por uma sucessão de abóbodas chatas. No edifício do Barreiro, Bolonha apresenta a mesma estratégia projetual usada por Niemeyer para a configuração de um terraço, surgido, em ambos projetos, onde finda uma das lajes planas no sentido do aclive. Porém, aqui, Bolonha tira partido da irregularidade do terreno, acompanhando sua inclinação para a configuração do terraço como mirante, no projeto de Niemeyer, o edifício encontra-se sobre pilotis. É importante realçar como Bolonha faz tais interlocuções, adequando-as à realidade do parque de Araxá.

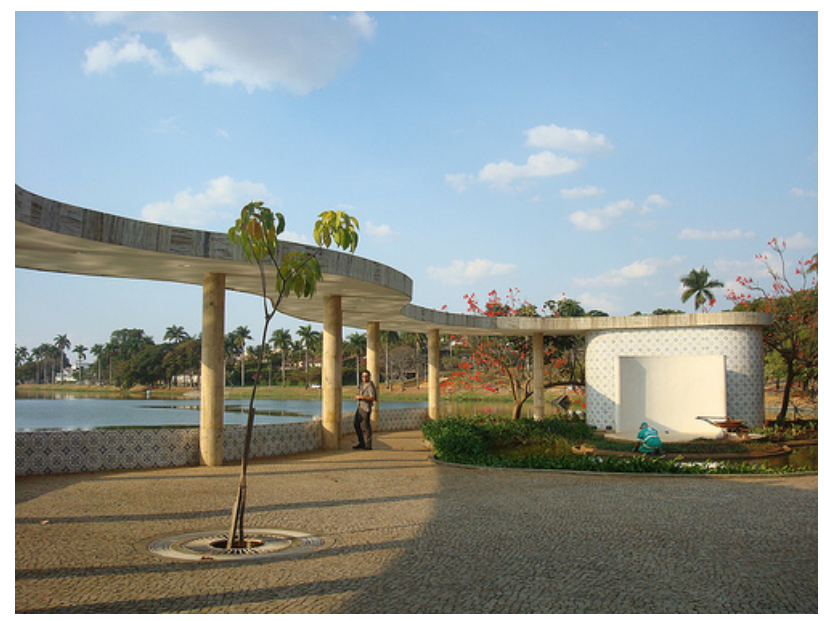

33. Casa do Baile. Pampulha. Fonte: da autora.

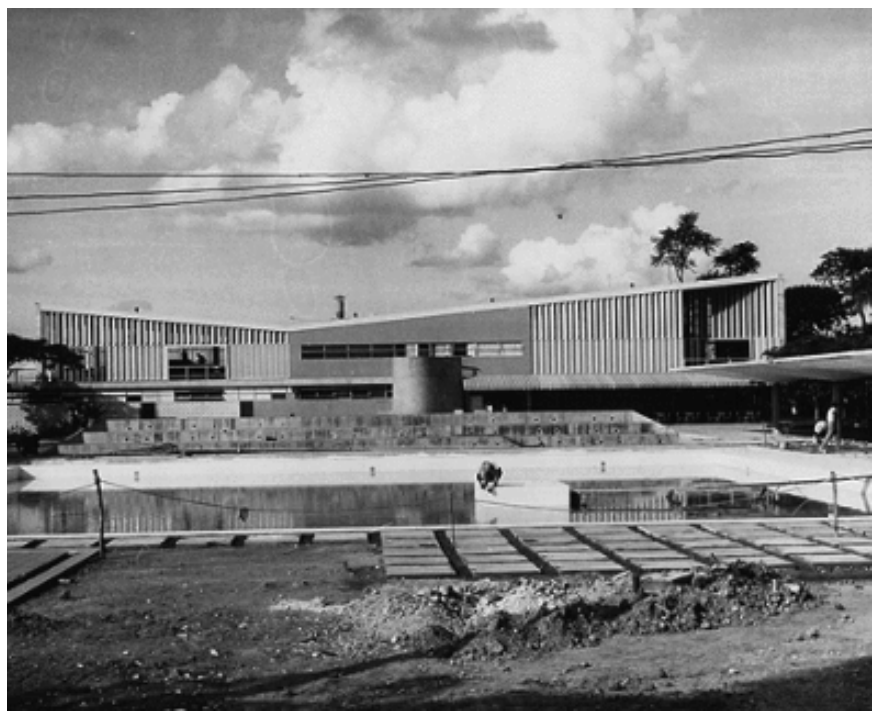

34. late Clube. Pampulha. Fonte: Acervo Histórico late Tênis Clube. 


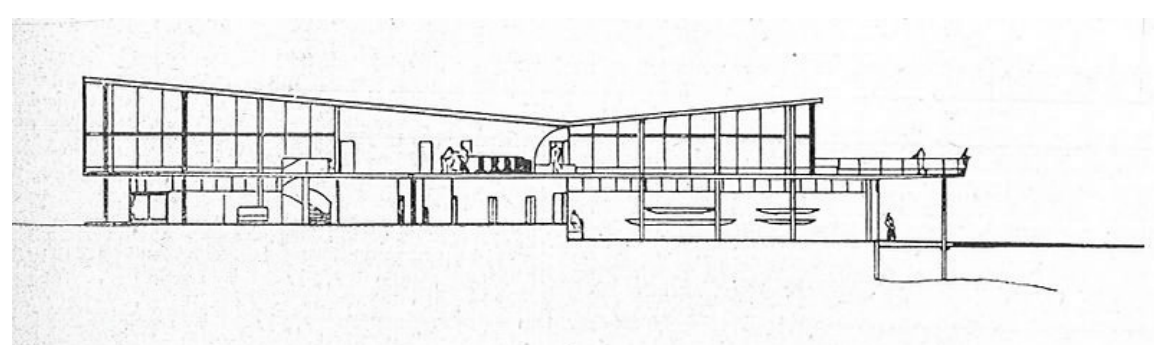

35. late Clube. Pampulha. Corte. Fonte: BOTEY, 1996

É importante ainda apontar como o projeto de arquitetura moderna de Bolonha para a Fonte Andrade Junior e o Grande Hotel e Termas do arquiteto Signorelli, em estilo eclético, revelam o embate entre duas arquiteturas com a mesma intensão de "modernização", as quais deveriam refletir a economia pujante de Minas Gerais do período. Ora, para cada arquiteto, a forma arquitetônica "moderna" tinha partidos formais bem distintos, os quais, ainda assim, conseguiam, de ambas as maneiras, refletir, ou pela grandiosidade, ou pelo progressismo artístico, a ideia de um país que passava por um período de "modernização".

A Fonte Andrade Junior, juntamente ao conjunto paisagístico de Burle Marx, é parte integrante do Complexo Hidrotermal e Hoteleiro do Barreiro, tombado pelo IEPHA Minas Gerais e registrado na categoria "Conjunto Paisagístico" - Decreto - Constituição Estadual - Ano: 1989. 


\section{O Complexo Industrial da Fertiza - Raphael Hardy Filho}

Embora a introdução da arquitetura moderna no Triângulo Mineiro tenha se dado de maneira acanhada, meio ao embate de concepções artísticas do Parque da Estância do Barreiro, seria através do próprio parque que Raphael Hardy Filho teria a oportunidade de projetar seu primeiro grande complexo moderno.

Na década de 1950, Araxá experimentaria o impacto da arquitetura moderna na cidade sobre maiores dimensões. Raphael Hardy Filho, arquiteto que já havia deixado um projeto na Estância do Barreiro de Araxá - a Fonte Dona Beja em estilo missões - agora seria o responsável pelo projeto das Instalações Industriais da Fertiza, antiga empresa de mineração e agricultura, atual Complexo da Codemig (Cia de Desenvolvimento Econômico de Minas Gerais). Projetado entre os anos de 1954 e 1955, o complexo constitui, em seu conjunto, a maior obra de arquitetura moderna de Araxá e uma das maiores obras modernas do Triângulo Mineiro e Alto Paranaíba.

Raphael Hardy Filho, começou sua trajetória profissional na mesma cidade, em 1938, como arquiteto-auxiliar da Comissão de Obras do Barreiro sob a orientação do arquiteto Luiz Signorelli, autor do Grande Hotel e Termas de Araxá. Hardy, formado em 1937 pela primeira turma ${ }^{40}$ da Escola de Arquitetura de Belo Horizonte $(\mathrm{EABH})$ - atual Faculdade de Arquitetura da UFMG - é conhecido por sua importância no papel da consolidação da escola, tornando-se professor da instituição após sua graduação, entre os anos de 1958 a 1977, contribuindo para a qualidade do ensino e da produção da arquitetura moderna desenvolvida em Minas Gerais e no Brasil.

\footnotetext{
${ }^{40}$ Apesar de pertencer a primeira turma da EABH, formada em 25 de Maio de 1937, Raphael Hardy Filho formou-se em 29 de Novembro de 1937, com mais dois arquitetos, Shakespeare Gomes e Edmundo Bezerril Fontenelle.
} 
Hardy Filho nasceu em Viçosa (1917-2003), filho de Raphael Hardy (1893-1968), arquiteto, músico, um dos precursores do art déco na capital mineira. Seu filho, Álvaro Hardy, conhecido como Veveco Hardy (1942-2005), foi também arquiteto atuante em Belo Horizonte e em outras cidades brasileiras. $\mathrm{Na} \mathrm{EABH}$, Hardy lecionou Perspectiva, Estereotomia e Sombras no grau de Doutor e, posteriormente diretor da escola. Em sua carreira profissional também trabalhou na Secretaria de Viação e Obras Públicas e foi Superintendente da COHAB-MG. No conjunto da sua obra há desde residências, conjuntos residenciais, além de edifícios institucionais, comerciais e públicos. Em Belo Horizonte, destacam-se o Fórum Lafayette, a sede do IPSEMG (Instituto de Previdência Social do Estado de Minas Gerais), o edifício residencial Nossa Senhora de Fátima, e a sede de Usiminas na Pampulha, a qual projetou com seu filho Veveco e Istvan Farkasvolgyi. Em Araxá, além da Fertiza, ainda projetou os edifícios modernos de dois grupos escolares, inclusive o do Barreiro, já previsto no plano urbanístico da área. Foi presidente do IAB-MG entre os anos de 1945 e 1946 e exerceu, nessa mesma instituição outras funções em períodos distintos da década de 1940 e 1950. Discípulo de Ângelo Murgel, sofreu ainda forte influência de Oscar Niemeyer. Publicou três livros: "Em busca de uma Arquitetura Brasileira", "Pesquisa e Planejamento" e "A Perspectiva e o Arquiteto Contemporâneo".

As Instalações Industriais da Fertiza continham ao todo seis edifícios, sendo eles: um portão de entrada principal; um edifício para vestiários e refeitórios; ambulatório; um edifício para almoxarifado-oficina-garagem; estação ferroviária; e administração. Os edifícios foram implantados em uma vasta área, em uma região periférica da cidade. No terreno, Hardy agrupa, próximo à entrada principal à Avenida Tancredo Neves, o pequeno edifício para a portaria, o edifício para os vestiários e refeitórios, e o edifício para o ambulatório, dispostos lado a lado defronte à uma das vias internas projetadas por Hardy. Desse grupo de edifícios até o outro mais próximo, formado pelos prédios para 
o almoxarifado-oficina-garagem e estação ferroviária, um conjunto de praças com recortes triangulares faz a interseção. Mais distante, encontra-se o edifício da administração, com acesso próprio desde a Avenida Tancredo Neves.

36. Fertiza. Imagem aérea. Fonte: elaborado pela autora - NUTHAUFAUeD / UFU.

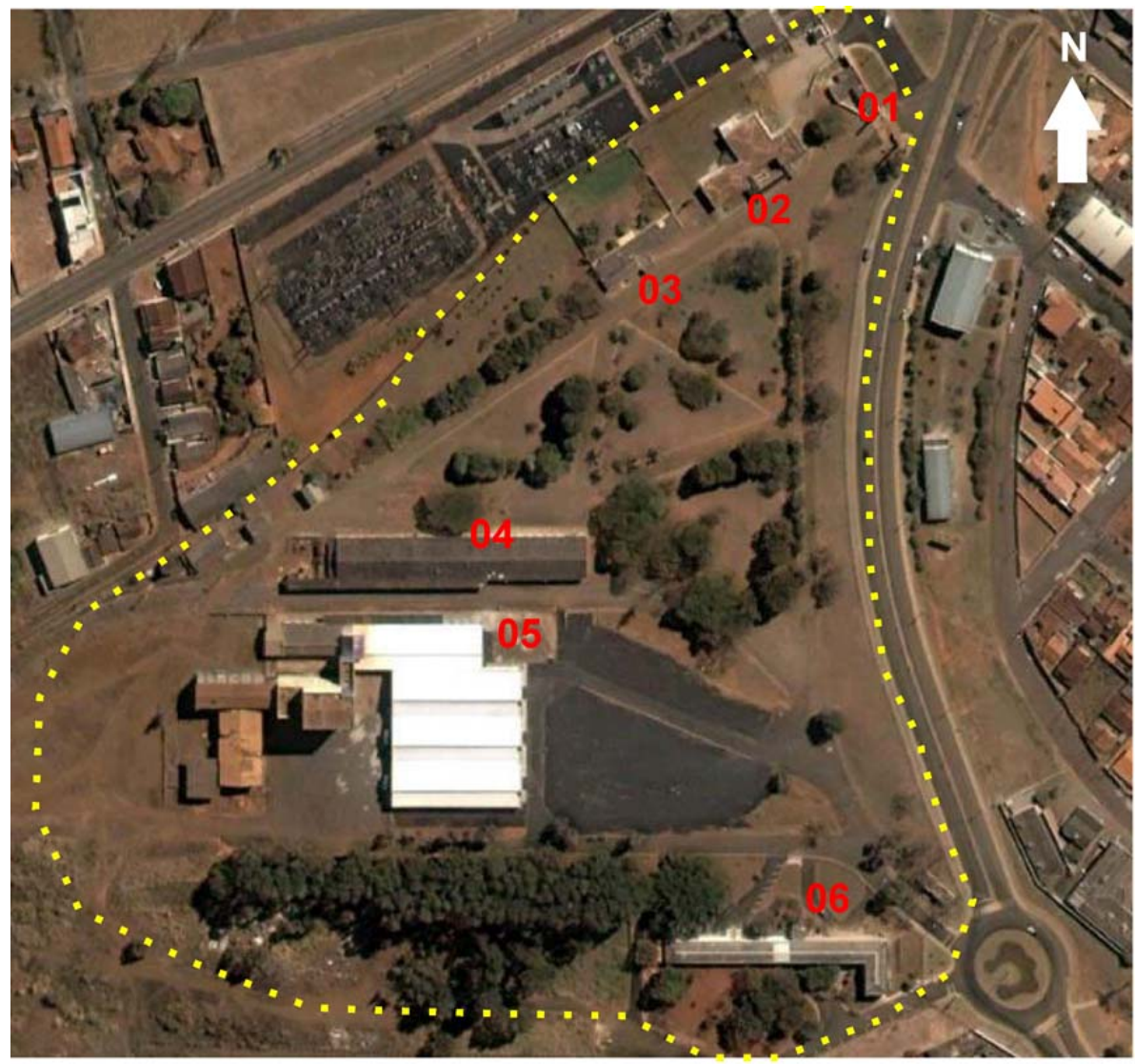

01- Portão de Entrada Principal 02 - Vestiários e Refeitórios 03 - Ambulatório

04- Almoxarifado - Oficina - Garagem 05 - Estação Ferroviária 06 - Administração

O acesso principal do complexo é marcado por dois elementos verticais, facilmente avistados pela baixa densidade da área e o baixo gabarito das edificações do entorno. A portaria compreendia um portão com entradas separadas para veículos e pedestres e uma pequena edificação residencial de controle. Esta possuía acesso próximo ao portão de pedestres, dando entrada à uma área aberta de controle geral e em seguida, para o interior da edificação chegando ao escritório. Além do escritório, foram dispostos dois quartos, um 
banheiro, sala de estar, copa, cozinha e uma varanda. A fachada exterior é configurada pelas linhas retilíneas do pequeno prédio, rompendo-se somente pelas duas torres em tijolo aparente que demarcam o portão de entrada. As torres desenhadas por Hardy medem mais de 15 metros de altura cada, localizadas após uma parede revestida em pedra. O uso das torres se apresenta como uma estratégia formal na caracterização do conjunto e também urbana, ao passo que foi usada para contrastar a característica horizontal da cidade na década de 50, tornando-se um marco visual na área.

Atualmente, o pequeno edifício se encontra com algumas modificações, sendo a mais expressiva, o acréscimo do portal retangular com os escritos "Fórum da Justiça do Trabalho", atual uso do edifício para vestiários e refeitórios da Fertiza, próximo à entrada principal.

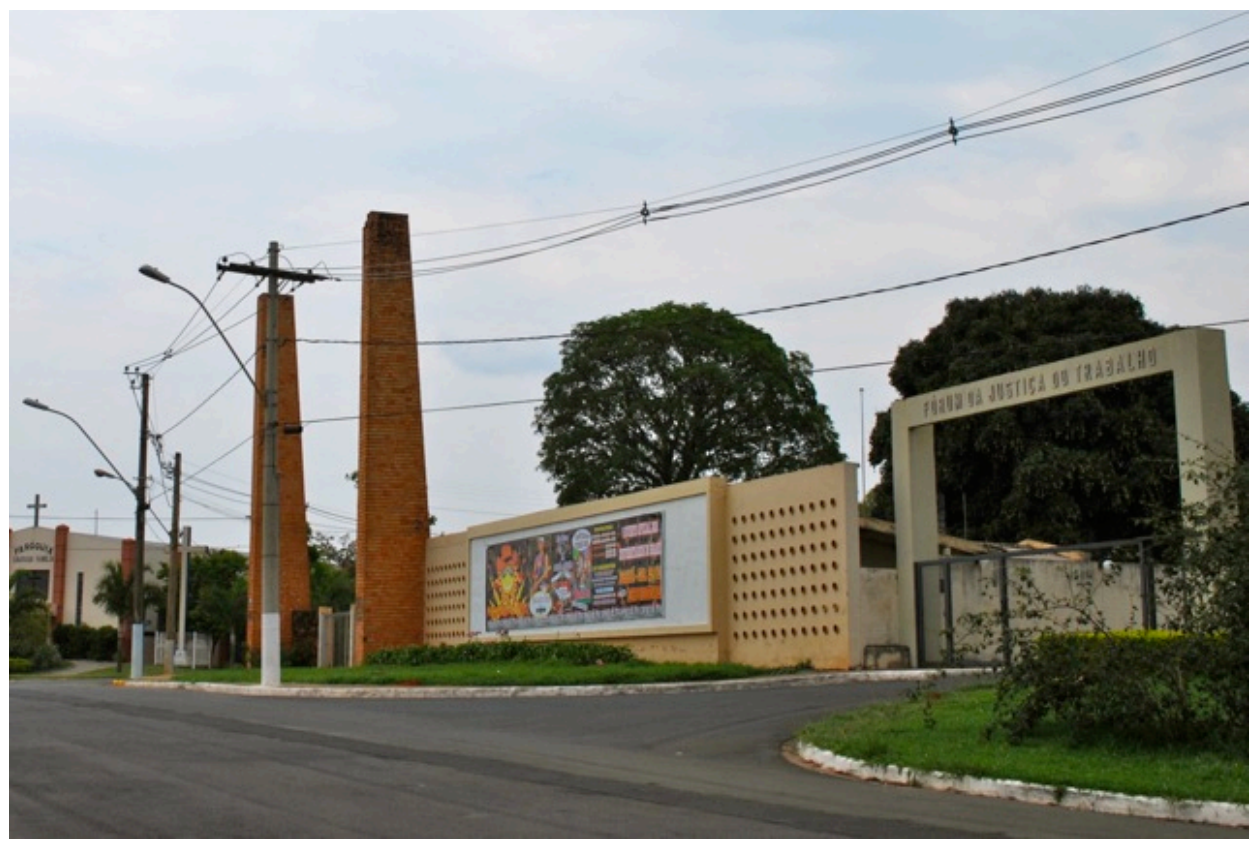

37. Fertiza. Portão de Entrada Principal. Fonte: NUTHAUFAUeD / UFU. 


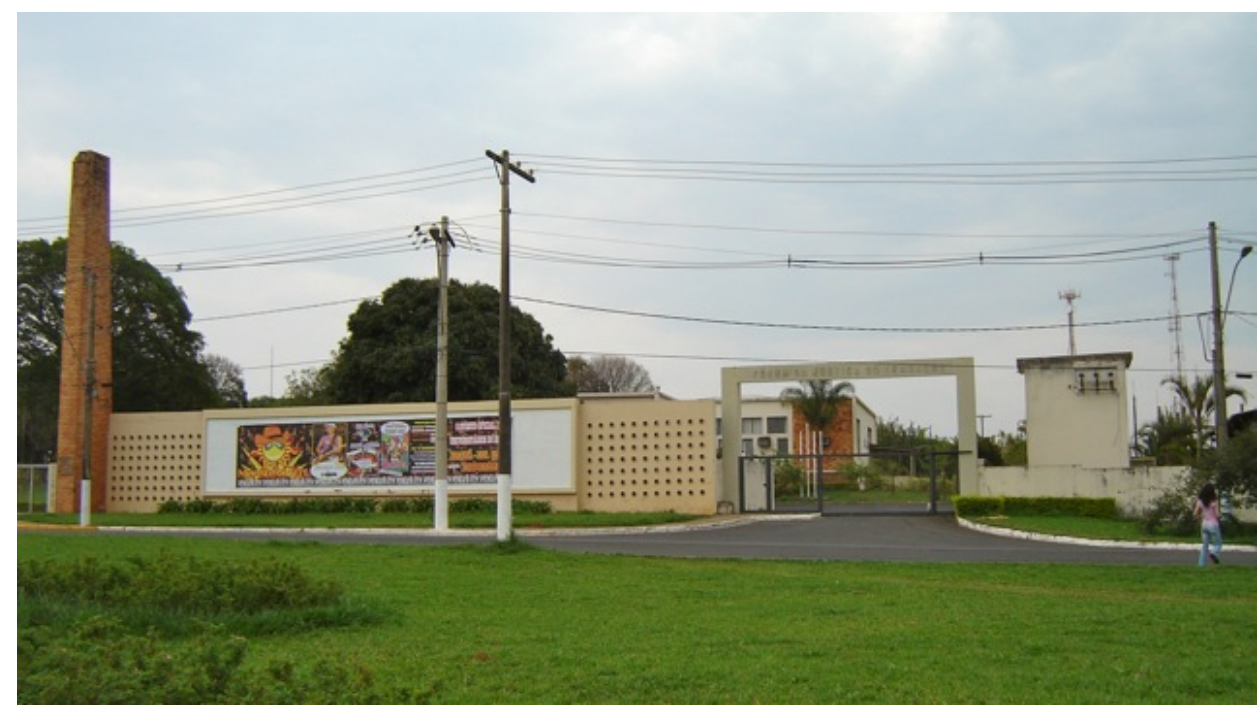

38. Fertiza. Portão de Entrada Principal. À direita, acréscimo do portal retangular, não correspondente ao projeto original. Fonte: NUTHAU-FAUeD / UFU.

39. Fertiza. Portão de Entrada Principal. Torre. Fonte: NUTHAU-FAUeD / UFU.

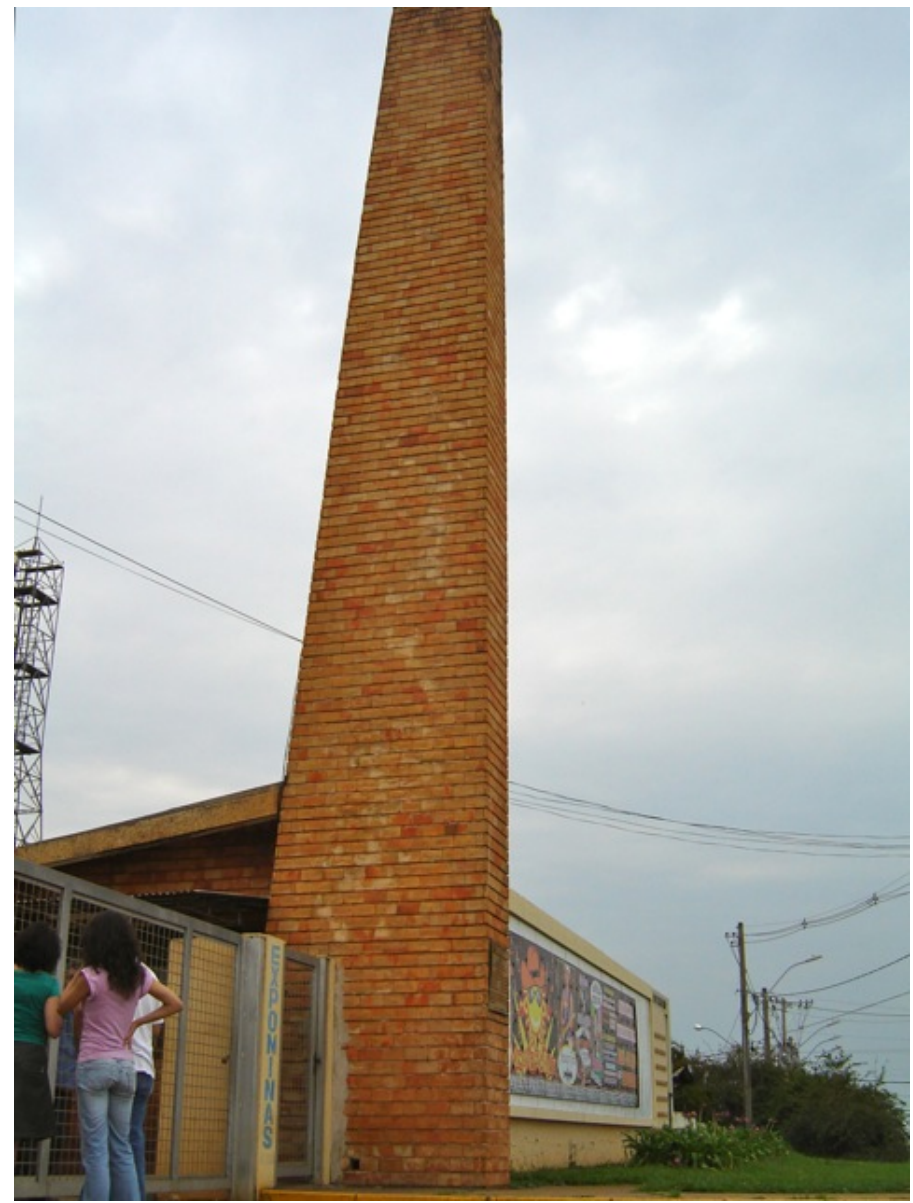




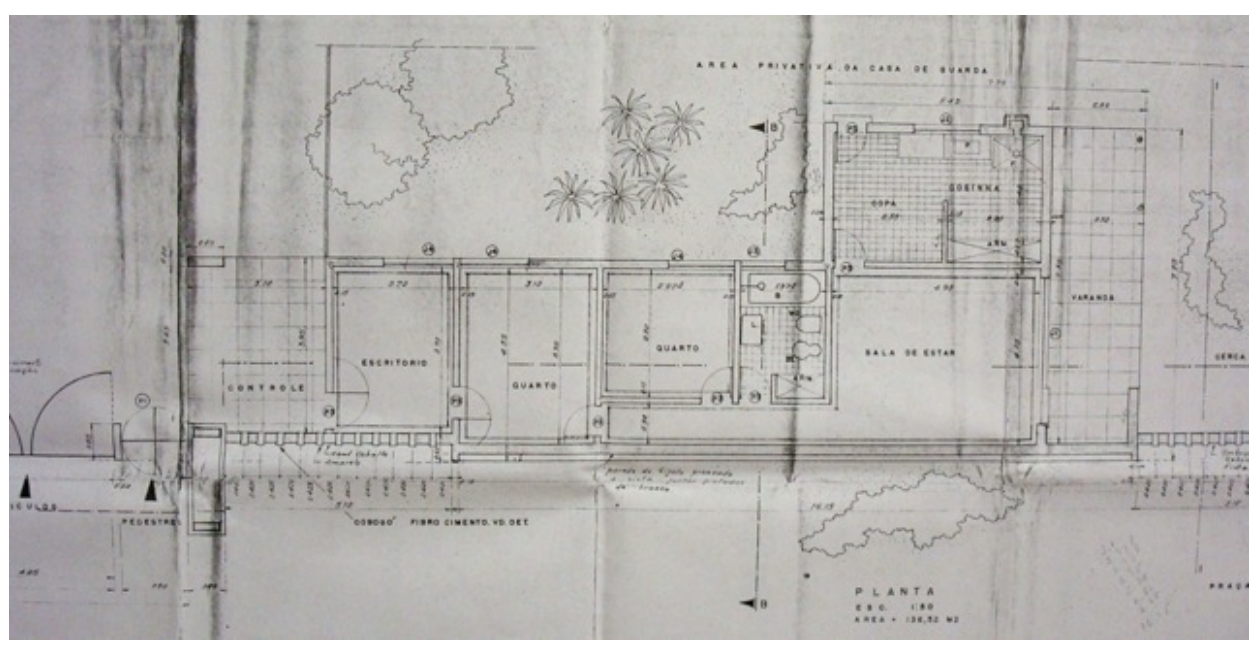

40. Fertiza. Portão de Entrada Principal. Planta. Fonte: NUTHAU-FAUeD / UFU.

Para os vestiários e refeitórios, Hardy projeta um edifício de volumetria recortada, de ângulos retos, com cobertura em platibanda, e usa como contraste o desenho sinuoso de um espelho d'água, localizado em um pátio externo em derredor das marquises da entrada principal que, infortunadamente, não foi executado. A planta do edifício configura-se em três blocos retangulares. À esquerda estão os sanitários, lavatórios e o vestiário. À direita, a entrada para o refeitório dos operários. Um acesso outro acesso foi colocado na extremidade direita da fachada sudeste, possibilitando a entrada direta para o refeitório exclusivo da administração, por meio de uma escada externa acompanhada de uma varanda. Separando o refeitório da administração e o refeitório dos funcionários está o núcleo de serviço, com cozinha, dispensa e lavanderia.

Marquises protegem todas as entradas do prédio e um passadiço coberto com uma estrutura em arcos chatos faz a ligação das mesmas. Aqui, Hardy retoma uma pesquisa feita por Le Corbusier nos projetos para casas em série, onde usou da técnica dos arcos chatos ao buscar soluções mais práticas, baratas e de estética pura. A cobertura em arcos chatos de Hardy é muito semelhante a usada por Le Corbusier no projeto da Casa Monol, de 1919, 
sendo também bastante utilizada por outros arquitetos brasileiros. ${ }^{41}$ Lembramos que a solução em arcos chatos para coberturas também foi utilizada por Francisco Bolonha no projeto não executado para a Praça de Esportes, no Parque da Estância do Barreiro de Araxá, onde, como Hardy, Bolonha iniciou sua carreira.

Internamente, Hardy evidencia a estrutura do edifício em concreto armado, revestindo-a com pintura sobre chapisco, em contrate com os demais revestimentos internos, em geral, pintura sobre argamassa lisa. Os fechamentos são em alvenaria de tijolo furado ou cheio, onde este último se encontra aparente em algumas partes das fachadas. Nas paredes externas, os quadros salientes que emolduram as fachadas e alguns vãos das esquadrias, assim como as testadas das marquises, são revestidos em pastilha de porcelana, tipo mescla, nas cores branco, palha, amarelo e azul água. $\mathrm{Na}$ parede da fachada que compreende a escada externa, à direita, pedaços de tubo "brasilit" de diâmetro igual a 2 polegadas e meia foram engastados na alvenaria revestida em caiação, contrastando com os revestimentos adjacentes, em pedra natural (baldrames), tijolo aparente e o próprio corrimão metálico da escada. Esse volume encontra-se sobre pilotis sem revestimento, estando aparente o concreto natural da estrutura.

41. Fertiza. Vestiários e Refeitórios. Detalhe da parede revestida com tubos "brasilit". Fonte: NUTHAUFAUeD / UFU.

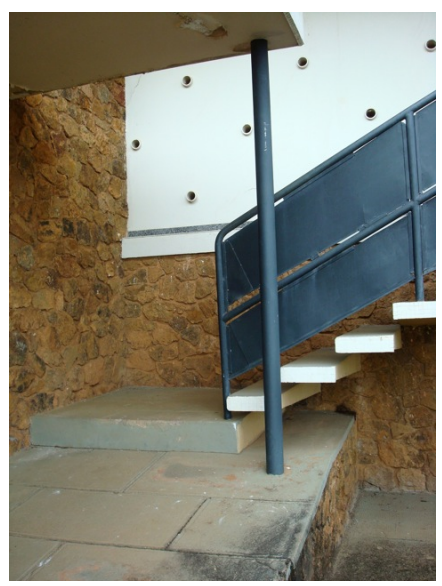

\footnotetext{
${ }^{41}$ A técnica de arcos chatos também pode ser vista nos projetos do Pedregulho, de Afonso Eduardo Reidy, de 1950-52, Rio de Janeiro-RJ; no Instituto de Puericultura, do Escritório Técnico da Cidade Universitária do Brasil (Arquiteto chefe: Jorge Moreira Machado), de 1953, Rio de Janeiro-RJ; e no Edifício para escritórios de Alcides Rocha Miranda, de 1948, em Petrópolis-RJ.
} 


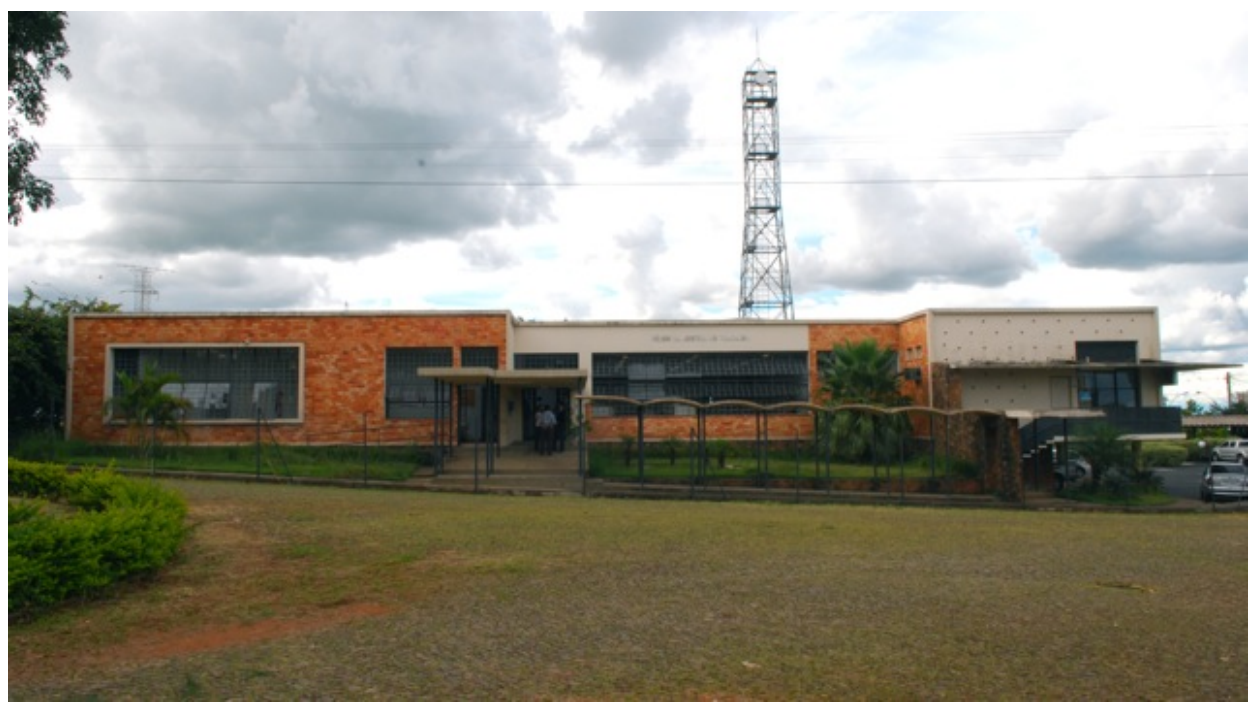

42. Fertiza. Vestiários e Refeitórios.

Fonte: NUTHAU-

FAUeD / UFU.
43. Fertiza. Vestiários e Refeitórios.

Fonte: NUTHAU-

FAUeD / UFU.

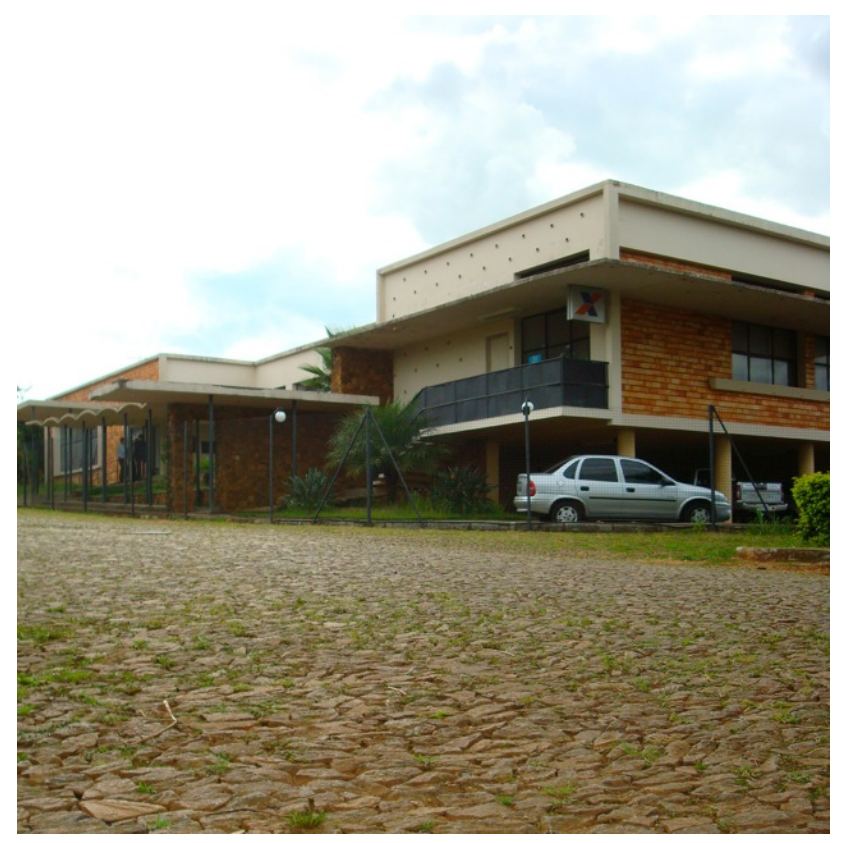


44. Fertiza. Vestiários e Refeitórios. Detalhe passadiço em arcos chatos. Fonte: NUTHAU-FAUeD / UFU.

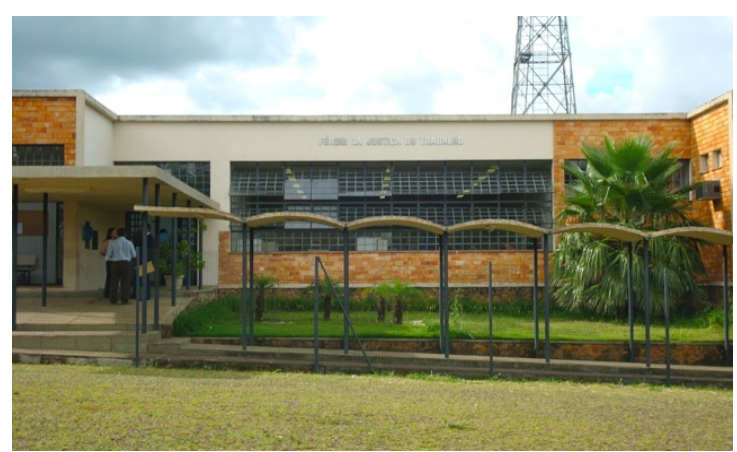

45. Casa Monol. Le Corbusier. Fonte: NUTHAU-FAUeD / UFU.
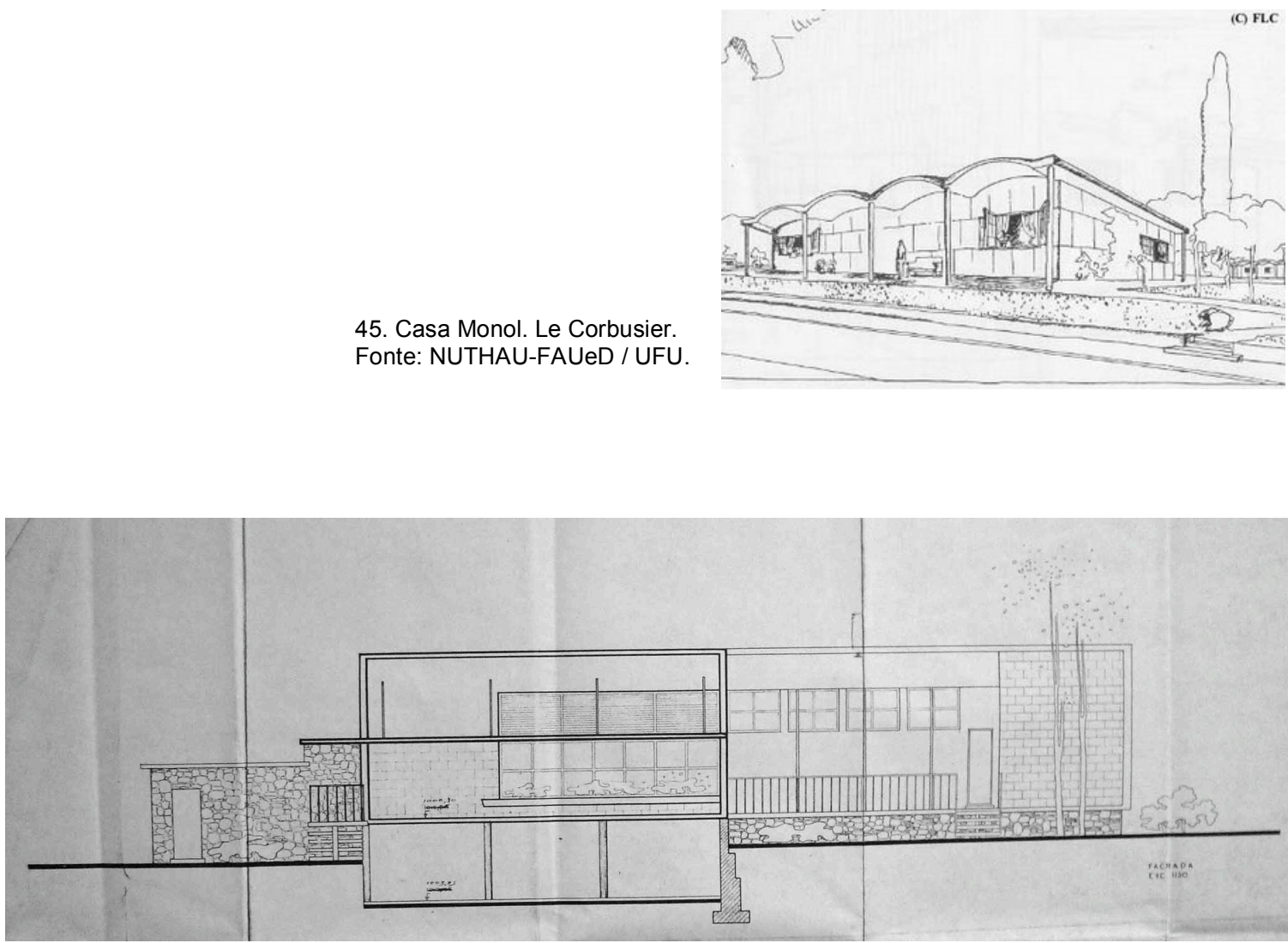

46. Fertiza. Vestiários e Refeitórios. Fachada nordeste. Fonte: Acervo Codemig. NUTHAU-FAUeD / UFU. 


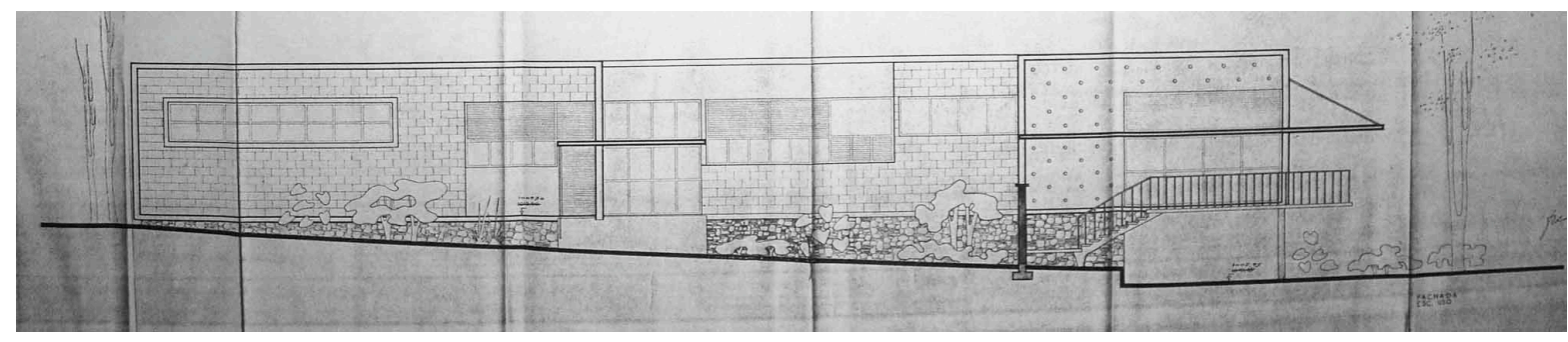

47. Fertiza. Vestiários e Refeitórios. Fachada sudeste. Fonte: Acervo Codemig. NUTHAU-FAUeD / UFU.

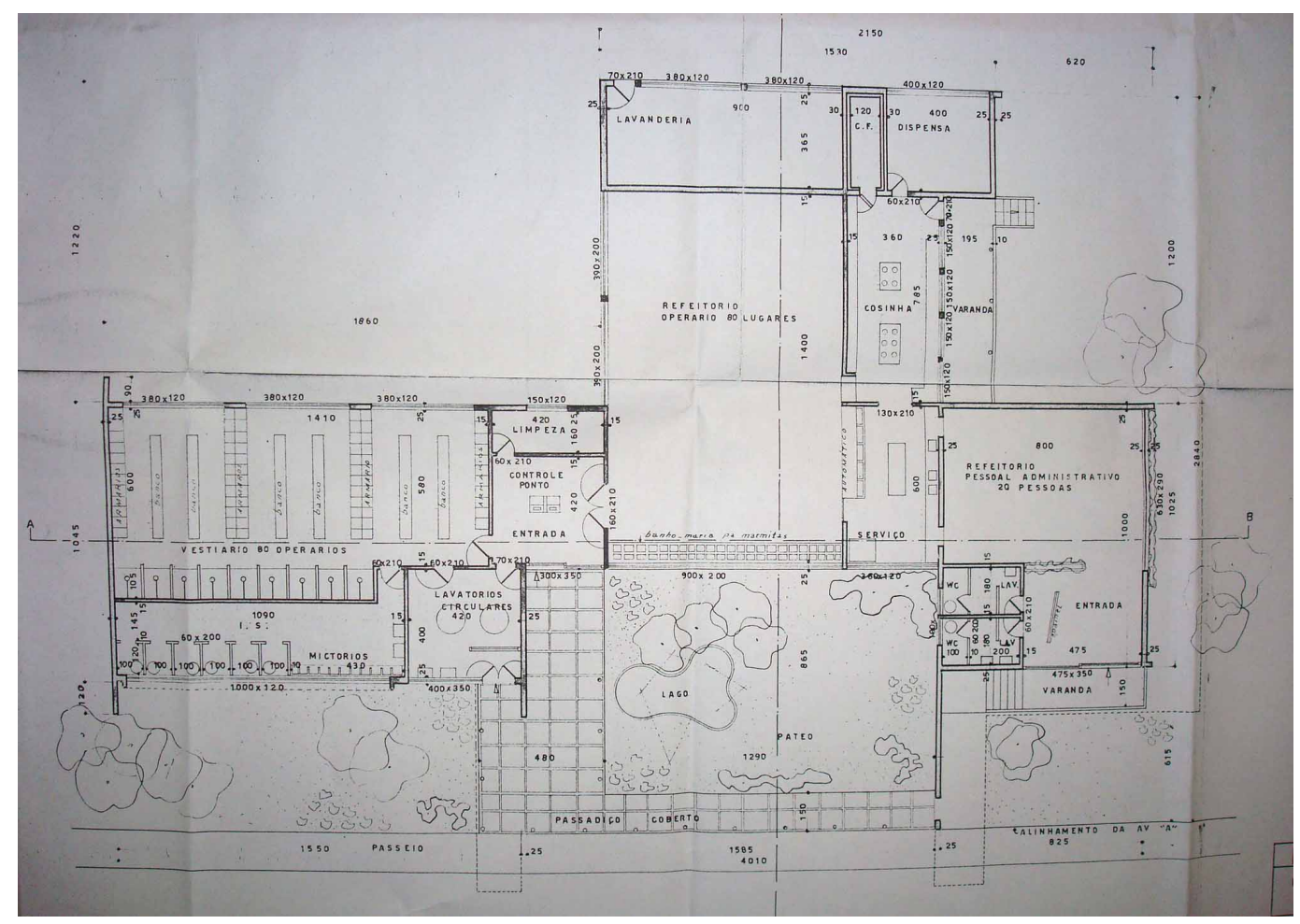

48. Fertiza. Vestiários e Refeitórios. Planta. Fonte: Acervo Codemig. NUTHAU-FAUeD / UFU.

O antigo ambulatório do Complexo Industrial da Fertiza está situado a 10 metros de distância do edifício para vestiários e refeitórios, mantendo o alinhamento com este e adequando sua implantação ao terreno irregular. Possui dois acessos, ambos na fachada sudeste. O principal é protegido por uma marquise, possui entrada recuada, sendo acessado por uma rampa de leve inclinação. O outro está situado na extremidade esquerda e compreende o acesso de serviço. Sua configuração interior inclui um corredor de circulação central que distribui lateralmente os cômodos que atendem o programa do ambulatório. 
Tem sua estrutura toda em concreto armado com cobertura em platibanda. Os fechamentos em tijolo cheio, assim como nos prédios para vestiários e refeitórios, e na portaria, também ficam aparentes na conformação estética das fachadas, em contraste com as demais partes pintadas em caiação. Os quadros salientes que evidenciam o volume, as testadas das marquises e a parede da fachada nordeste recebem revestimento em mosaico "weiss", tipo cortiça. Os muros de arrimo, baldrames e o pilar de sustentação da marquise são revestidos em pedra apatita natural.

No projeto para o ambulatório, Raphael Hardy Filho concebe as fachadas do volume com alguns elementos de destaque, como os quadros salientes em volta das esquadrias em fita nas fachadas sudoeste e noroeste (lateral esquerda e posterior), o brise-soleil de fibrocimento na fachada noroeste, regulando a incidência do forte sol da tarde (já retirado), as esquadrias $30 \times 30 \mathrm{~cm}$ que fazem a iluminação de parte da circulação, e o pilar de sustentação da marquise revestido em pedra. Na fachada nordeste (lateral direita) seria fixado um desenho em ferro tubular que atualmente não se encontra no local ou não foi executado. Por ser um edifício horizontal e extenso, a mescla de revestimentos e elementos das fachadas foi essencial para a dinâmica formal do edifício. A iluminação de parte dos corredores, feita pelas aberturas $30 \times 30 \mathrm{~cm}$, é uma inovação técnica vista não somente neste prédio como também é encontrada no edifício da administração. Dão à fachada principal uma configuração ritmada por meio das diversas aberturas enfileiradas.

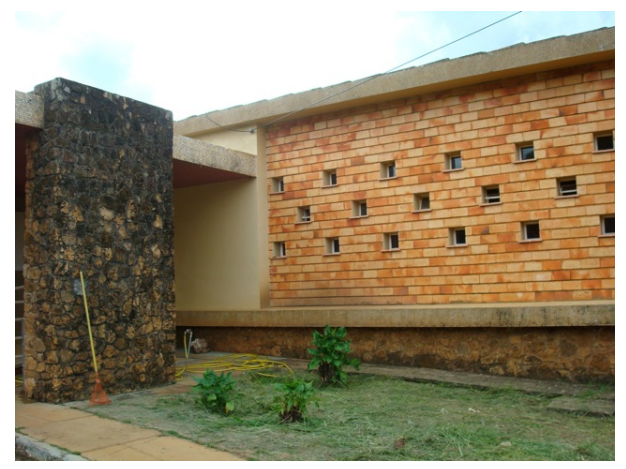


50. Fertiza.

Ambulatório. Fonte: NUTHAU-FAUED / UFU.

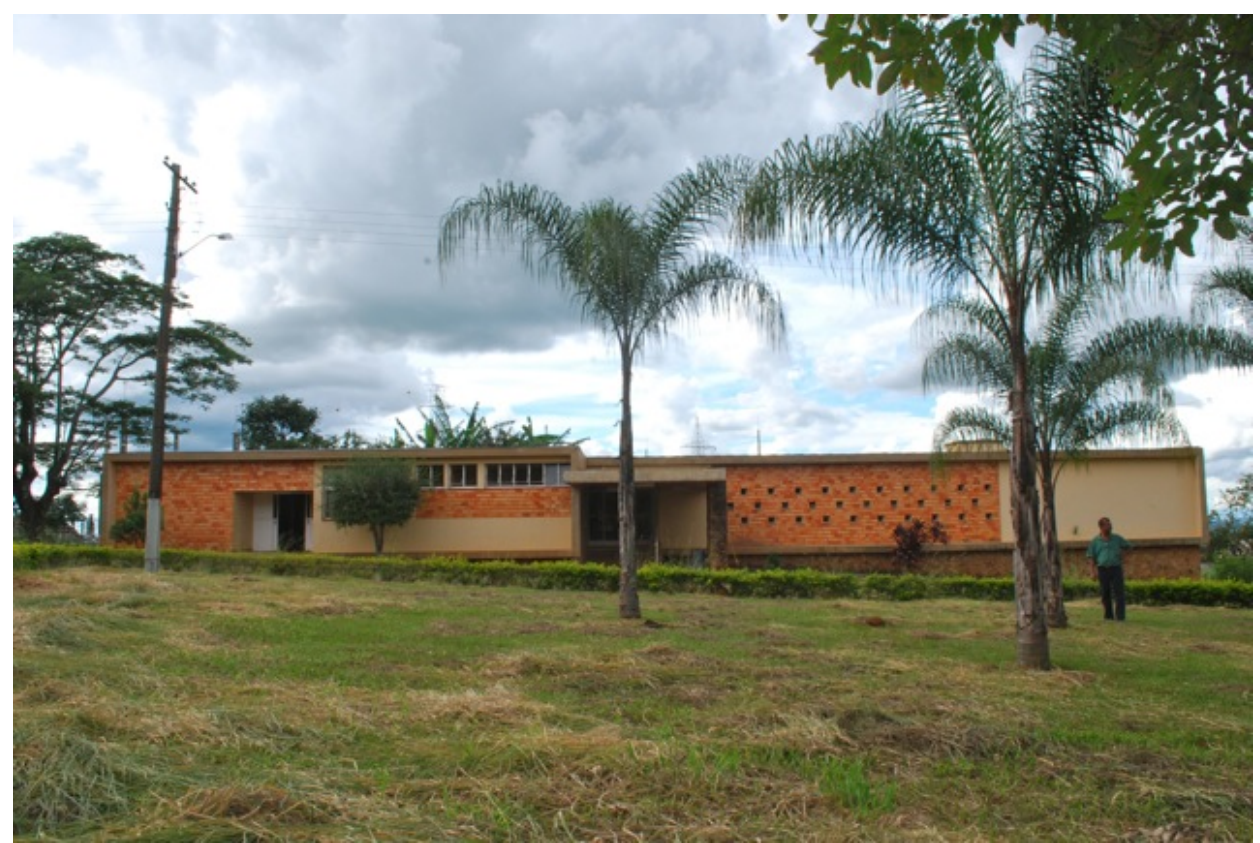

51. Fertiza.

Ambulatório. Fonte: NUTHAU-FAUED / UFU.

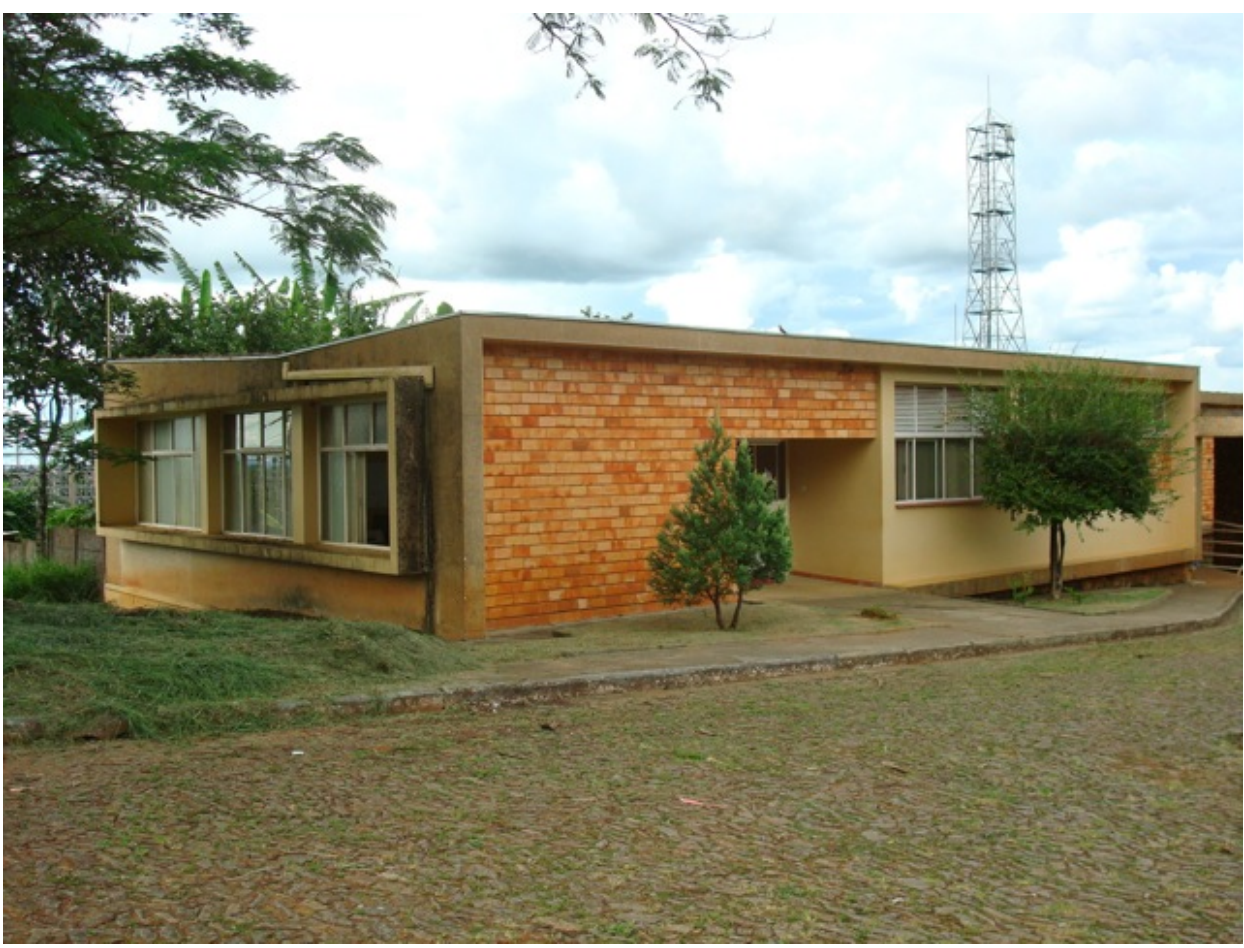



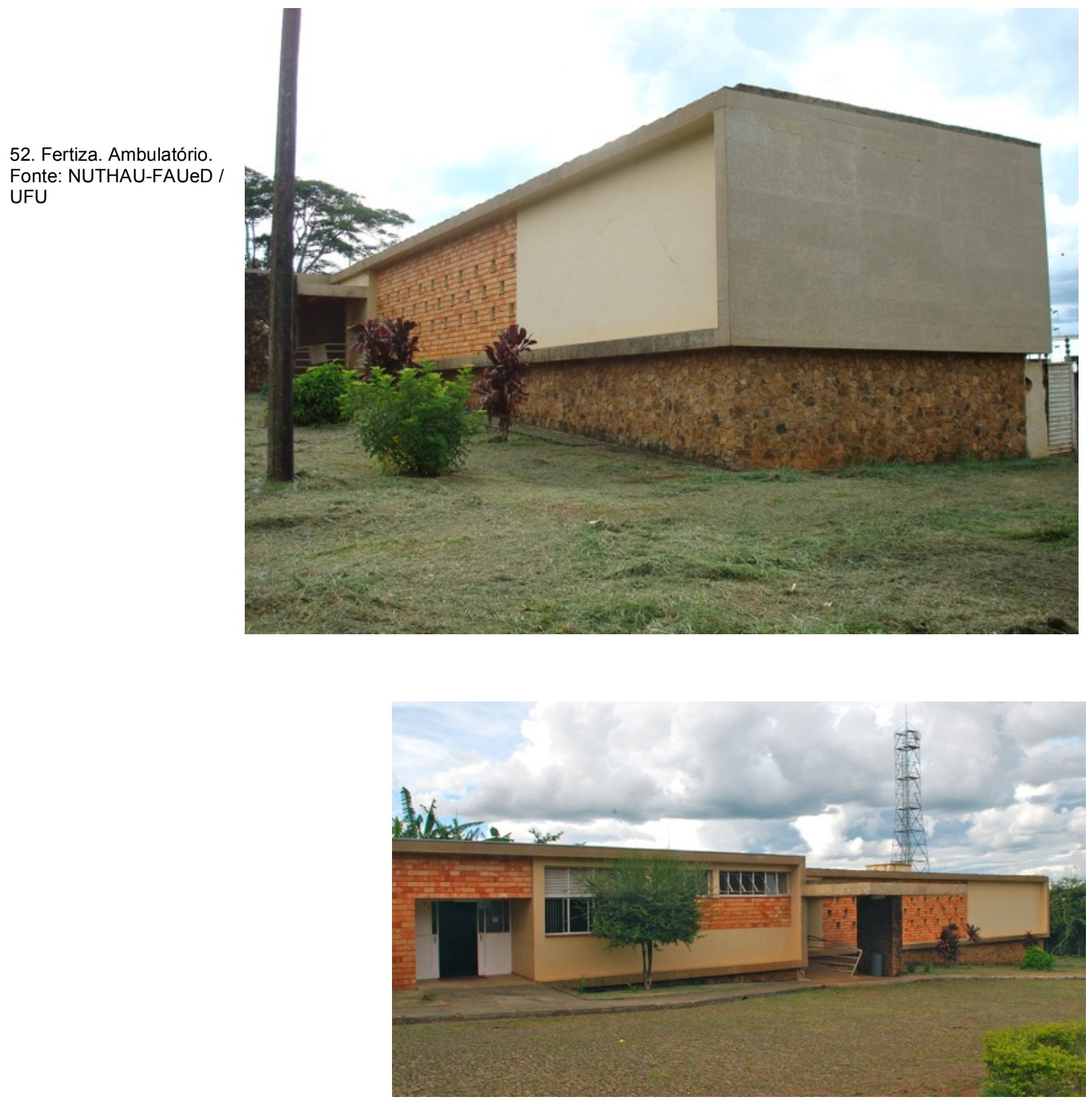

53. Fertiza. Ambulatório. Fonte: NUTHAU-FAUeD / UFU 


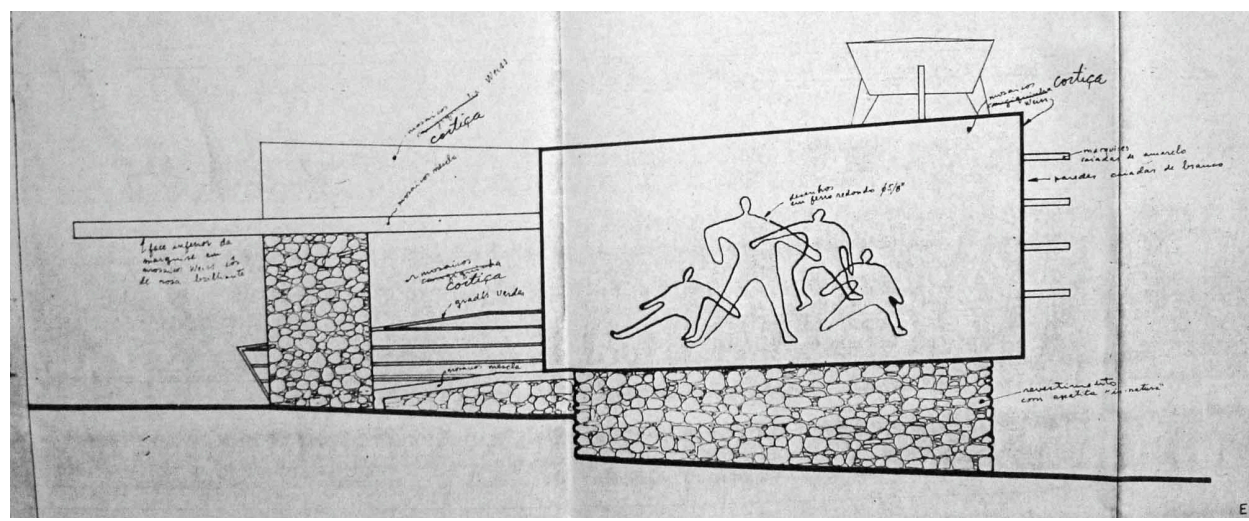

54. Fertiza. Ambulatório. Fachada nordeste. Fonte: NUTHAU-FAUeD / UFU

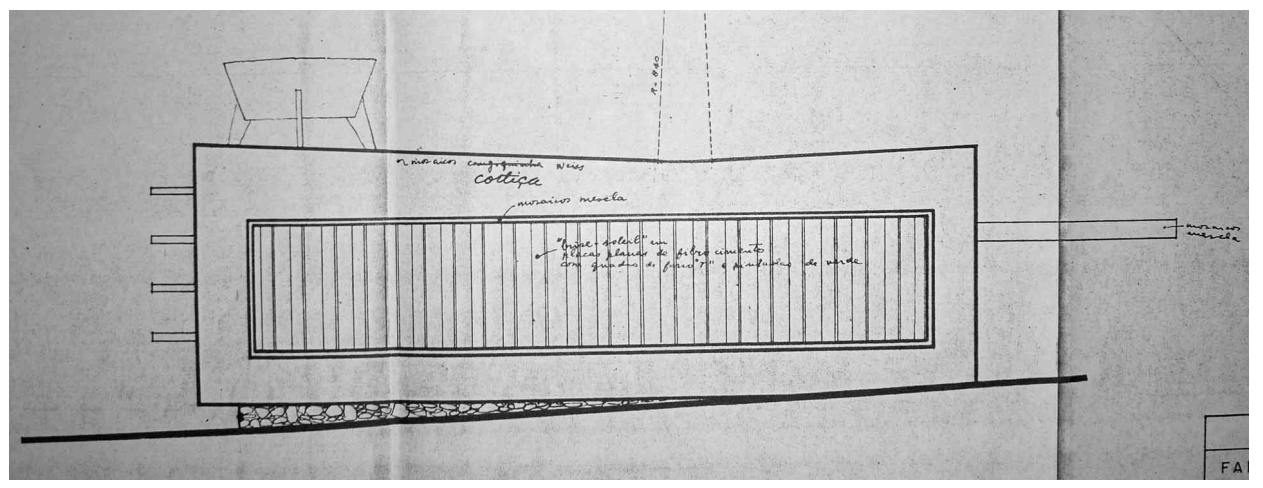

55. Fertiza. Ambulatório. Fachada noroeste. Fonte: NUTHAU-FAUeD / UFU

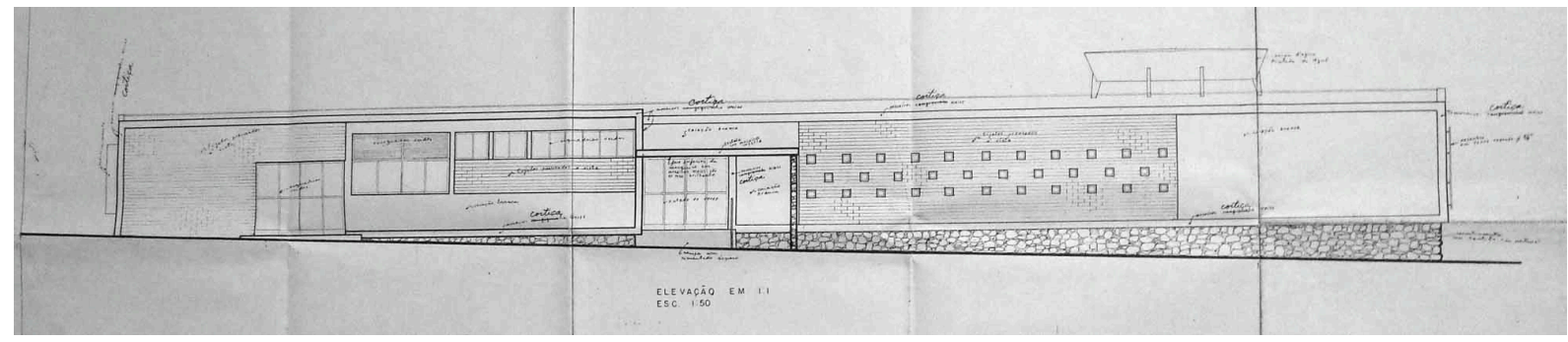

56. Fertiza. Ambulatório. Fachada sudeste. Fonte: NUTHAU- FAUeD / UFU

O edifício projetado para o almoxarifado-oficina-garagem, encontrase paralelo a estação ferroviária. A linha do trem separava os dois edifícios que dialogam em estrutura, volumetria e revestimentos. Segundo projeto original, possui quatro acessos principais, sendo dois na fachada paralela à Estação Ferroviária e outros dois na fachada posterior. Eles estão alinhados entre si e simétricos ao edifício. No interior, a configuração é simplificada e funcional, com poucos cômodos, deixando a área livre para a realização das atividades. $\mathrm{Na}$ 
extremidade leste está a oficina, originalmente sem fechamento, aberta para o exterior, conforme projeto de Hardy. $\mathrm{Na}$ parte central estão dispostos o almoxarifado, com sanitários, cozinha e café, e na extremidade oeste, a garagem. Uma marquise protege os acessos principais que se prolonga 20 metros desde o término do edifício.

O desenho da estrutura em concreto armado é o elemento de maior proeminência, o concreto era deixado a vista, originalmente. Os pilares em formato "bumerangue" desenhados por Hardy para a configuração estrutural, e que ao mesmo tempo conformam as fachadas principais do edifício, somam estética e função. Dinamizam a volumetria do edifício que demonstra contornos despojados, com pouquíssimos elementos de revestimento, como têm os demais edifícios do complexo.

Conforme projeto original de Hardy, os fechamentos seriam em tijolo cheio, os quais ficaram à vista nas fachadas externas. $O$ fechamento em alvenaria com pintura sobre argamassa, na parte do edifício destinada à oficina, e que pode ser vista na configuração atual das fachadas do prédio, é uma das várias alterações do projeto original. Também foram adicionadas outras esquadrias, novos acessos, e uma varanda coberta com telha ondulada de fibrocimento.

Para estação ferroviária da Fertiza , Hardy projeta um edifício semelhante ao edifício para almoxarifado-oficina-garagem. A estação destinava-se ao armazenamento e distribuição dos produtos da indústria. Possui volumetria simples, próxima à um galpão, fechado em alvenaria, contendo seus vãos abertos segundo proposta original. Os acessos principais, locados centralmente à fachada defronte a linha férrea são cobertos por uma marquise, que dialoga em concepção formal e estrutural com o edifício para almoxarifado-oficina-garagem. Percebe-se que Hardy projeta esses dois edifícios como um conjunto quase único, dialogando a volumetria e a 
concepção das fachadas, quase que espelhadas. Os outros três galpões encontrados atualmente no local, atrás da estação, foram adicionados posteriormente. É possível perceber que tentou-se dialogar a nova inserção com o projeto de Hardy, cuja volumetria se assemelha à da estação, projetada pelo arquiteto.

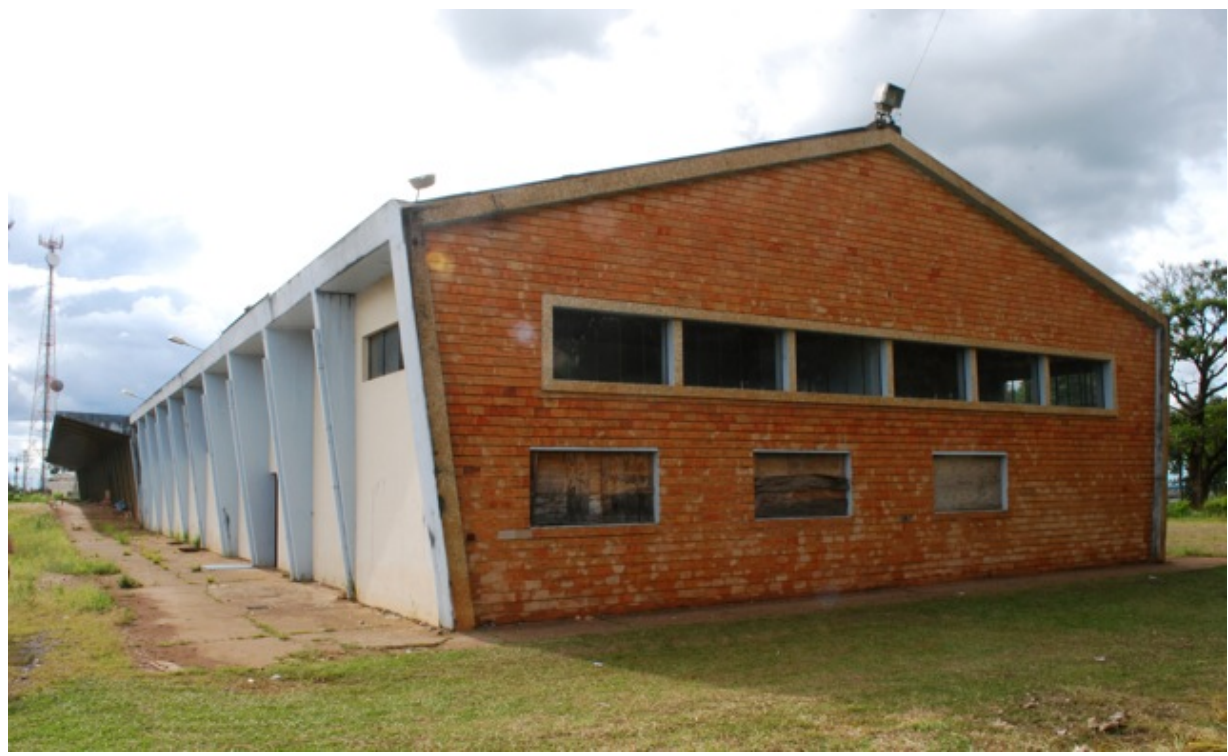

57. Fertiza.

Almoxarifado-Oficina-

Garagem. Fonte:

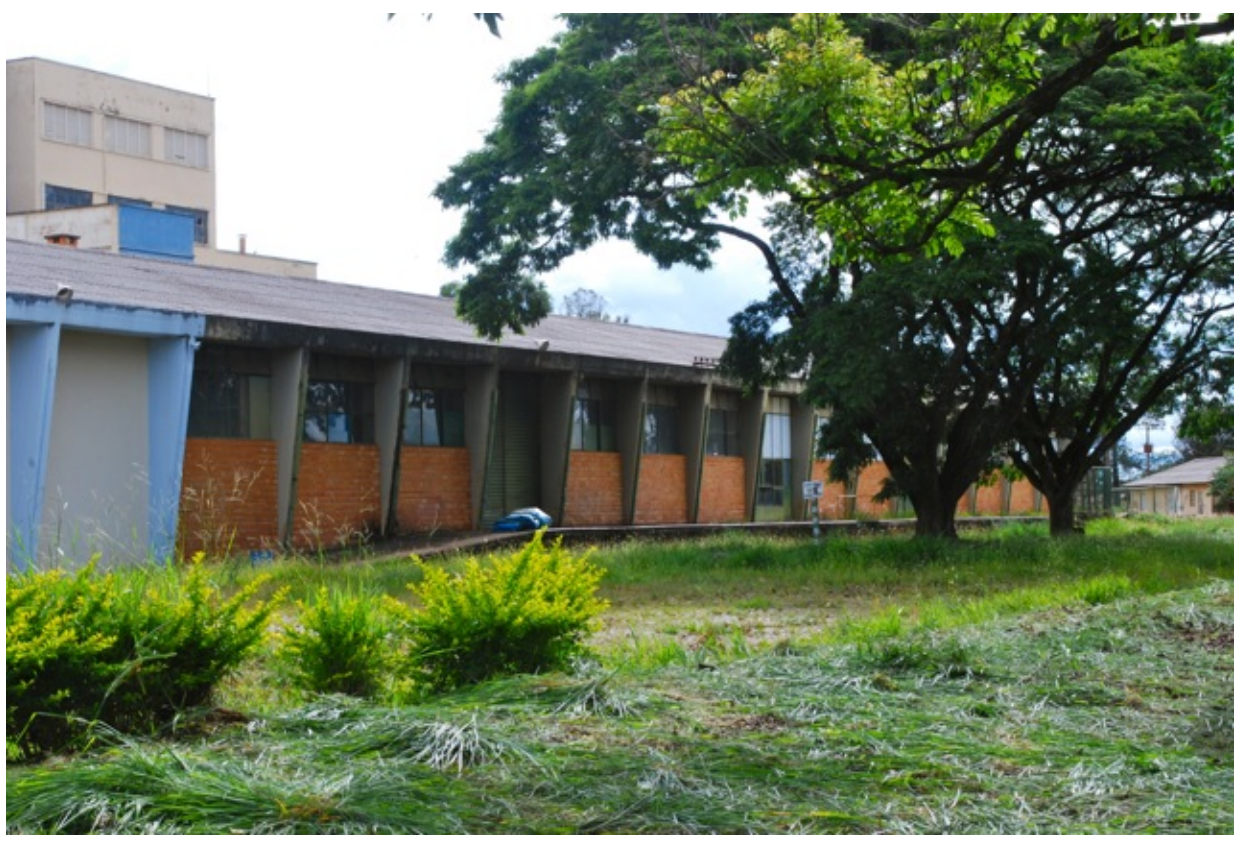

58. Fertiza. AlmoxarifadoOficina-Garagem. Fonte: NUTHAU- FAUED / UFU 
59. Fertiza. Almoxarifado-

Oficina-Garagem. Fonte: NUTHAU- FAUED / UFU

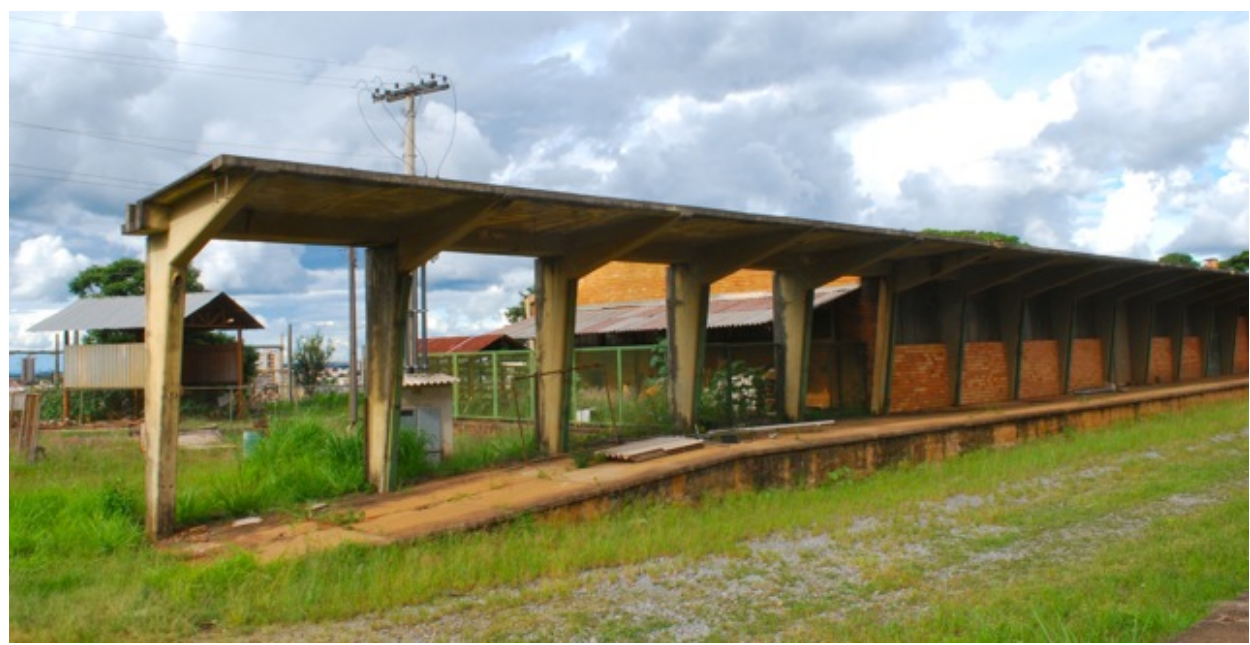

60. Fertiza. Almoxarifado-OficinaGaragem. Detalhe Estrutura. Fonte: NUTHAU-FAUeD / UFU

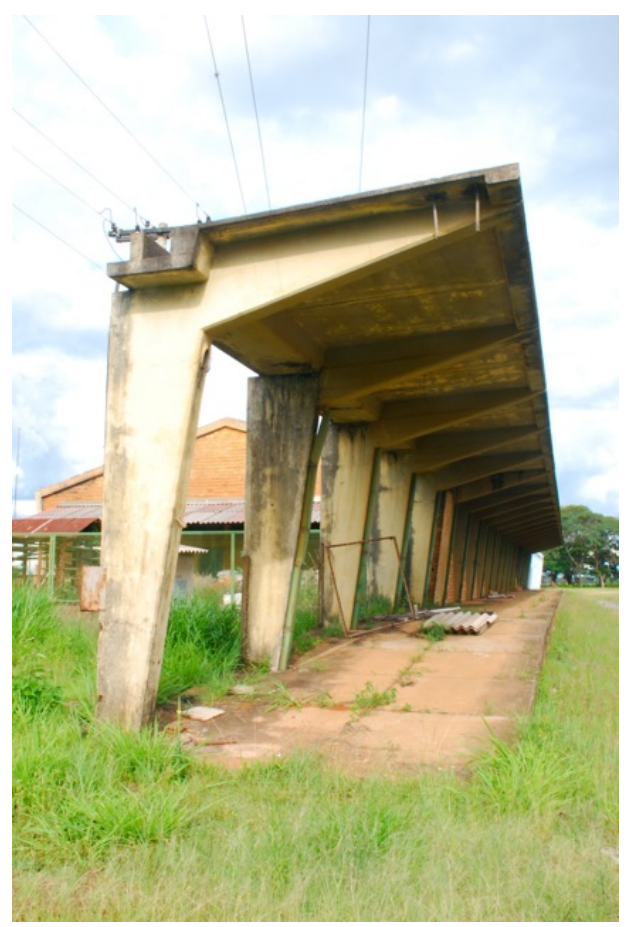

61. Fertiza. AlmoxarifadoOficina-Garagem, à esquerda. À direita, estação ferroviária. Fonte: NUTHAU-FAUeD / UFU

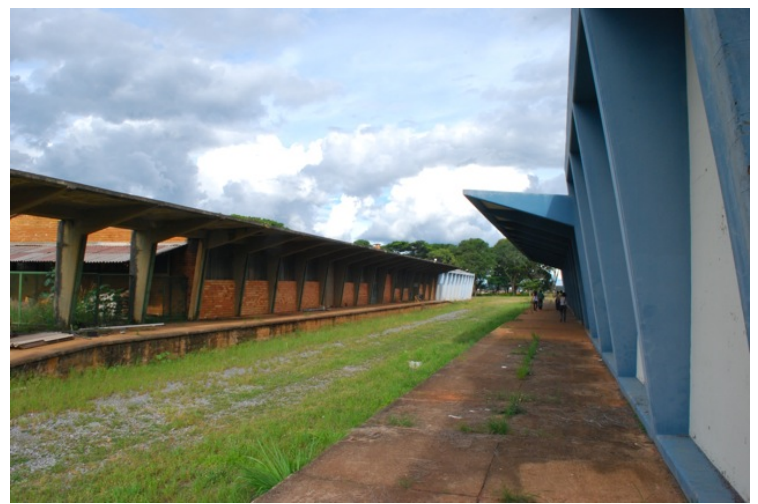




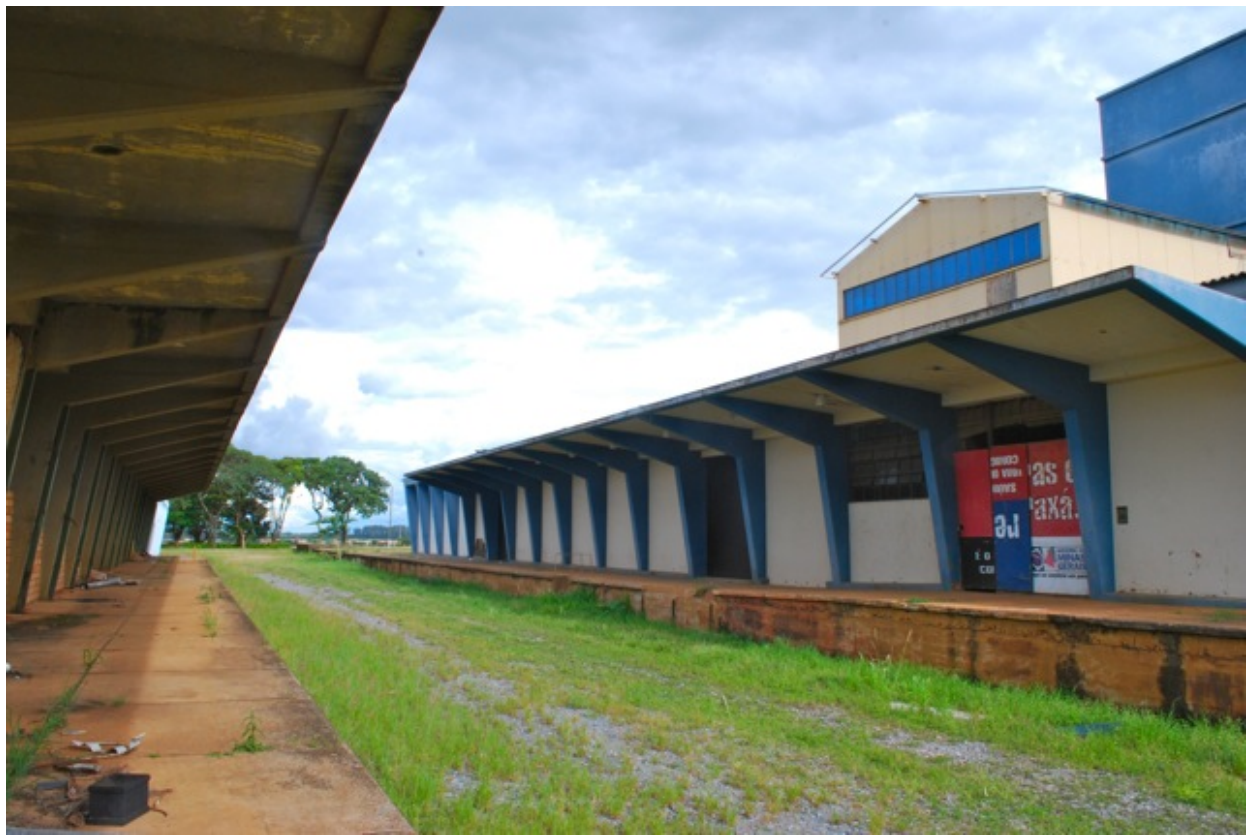

62. Fertiza. À direita, estação ferroviária. À esquerda, marquise do edifício para AlmoxarifadoOficina-Garagem, Fonte: NUTHAU-FAUeD / UFU

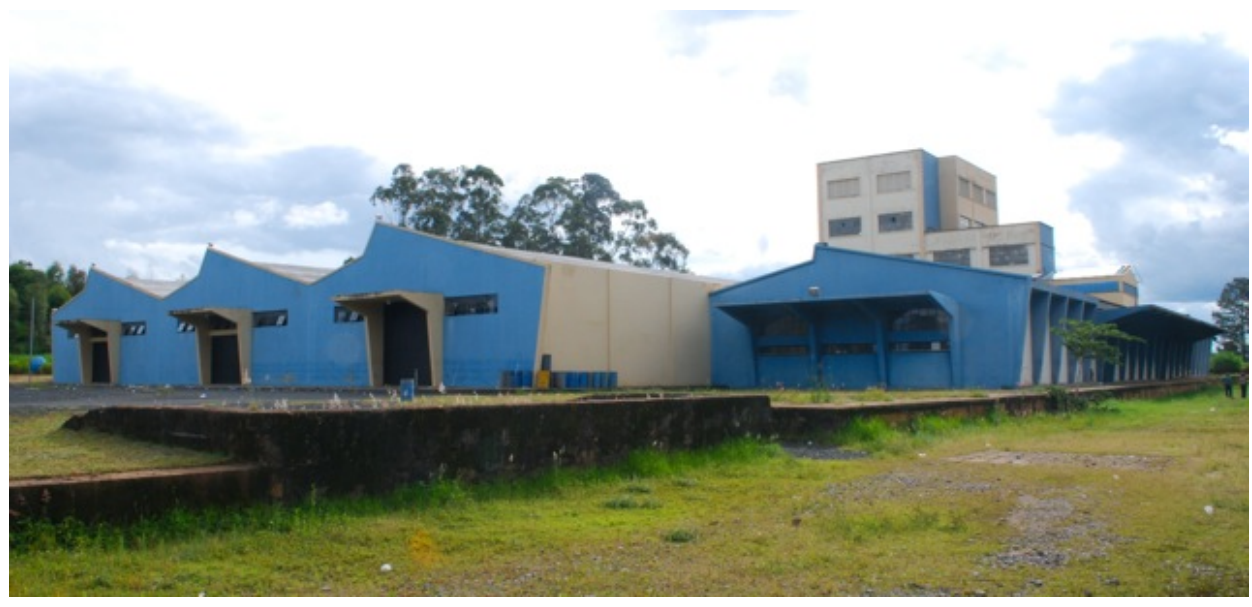

63. Fertiza. À direita, estação ferroviária original. À esquerda, os três galpões adicionados posteriormente. Fonte: NUTHAU-FAUeD / UFU

O edifício para a administração da Fertiza está implantado em um terreno irregular, de leve aclive na direção oeste. Tirando partido deste aspecto, o prédio projetado por Hardy se assenta ao terreno alinhando-se ao nível mais alto e prolongando-se até a extremidade leste, onde a implantação configurou uma área sobre pilotis, onde o edifício se "dobra", tomando formato de um "L". 
Possui três acessos, dois secundários na elevação norte e o principal, sobre os pilotis, onde o arquiteto desenhou uma área de transição interna/externa, com jardins, um espelho d'água e um painel retangular fixo, auxiliando na configuração de um ambiente reservado. Esta área possui um pé-direito baixo, onde é possível uma mulher de estatura mediana alcançar o teto esticando-se o braço.

No nível das repartições, dois corredores laterais surgem do hall principal, distribuindo ao todo, 19 cômodos mais sanitários. Hardy dispõe todos os sanitários centralmente na planta, mantendo também as áreas de circulação tangentes às paredes externas, artifício que deu ao arquiteto maior liberdade no desenho das elevações. Na elevação norte, na área sobre os pilotis, o arquiteto desenha um brise-soleil fixo, e no restante da fachada, dispõe as mesmas esquadrias $30 \times 30 \mathrm{~cm}$ encontradas no edifício para o ambulatório, aqui, dispostas em três faixas horizontais que permitem a iluminação do corredor lateral, já no nível do solo. A disposição das janelas e dos brise-soleil seguem o fator de incidência do sol em cada fachada, demonstrando a preocupação de Hardy quanto a funcionalidade do edifício e as atividades que seriam executadas nas suas dependências.

Assim como no edifício para vestiários e refeitórios, o prédio para a administração tem seu exterior marcado por uma mescla de revestimentos. Todos os fechamentos são em tijolo cheio ou furado, os quais também ficariam à vista nas paredes externas. Parte da fachada leste e parte da fachada norte, assim como todas as saliências do edifício, foram revestidas em mosaico de porcelana $2 \times 2 \mathrm{~cm}$, tipo mescla, nas cores branco, palha, amarelo e azul água. Também tem revestimento em mosaico os pilotis e o fundo do lago artificial (espelho d'água) próximo à entrada principal. Segundo especificações do projeto, as paredes do interior, em geral, apresentavam pintura sobre 
argamassa, com exceção das instalações sanitárias, com paredes revestidas em azulejo, e do hall, revestido com lambris até altura de $2,20 \mathrm{~m}$.

Atualmente, foram pintados na cor branca os tijolos cheios deixados à vista nas fachadas do edifício. Existia também uma estufa em estrutura metálica e vidro na extremidade oeste, a qual nas plantas aprovadas pelas Fertiza, em 1954/55, era parte integrante do projeto, sendo desconhecida a informação de sua construção.

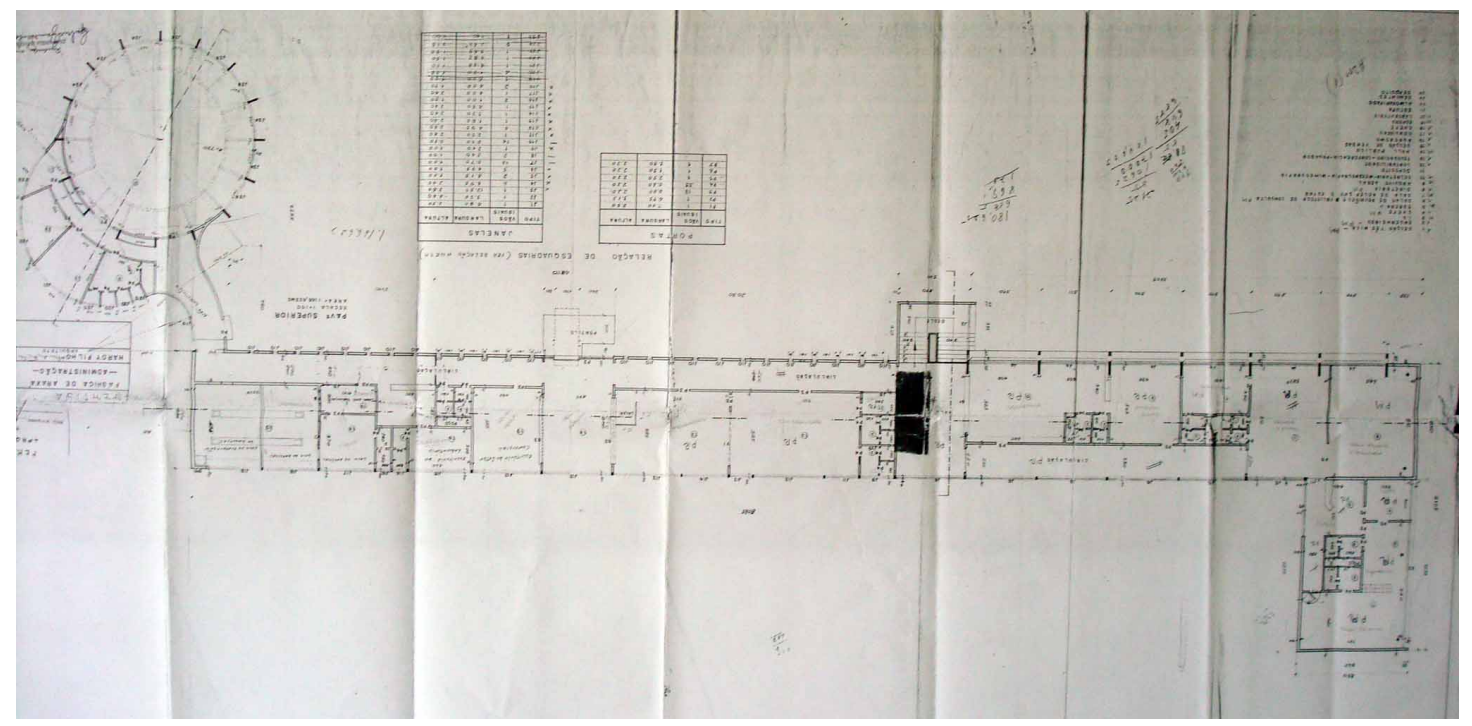

54. Fertiza. Administração. Planta. Fonte: Acervo Codemig. NUTHAU- FAUeD / UFU

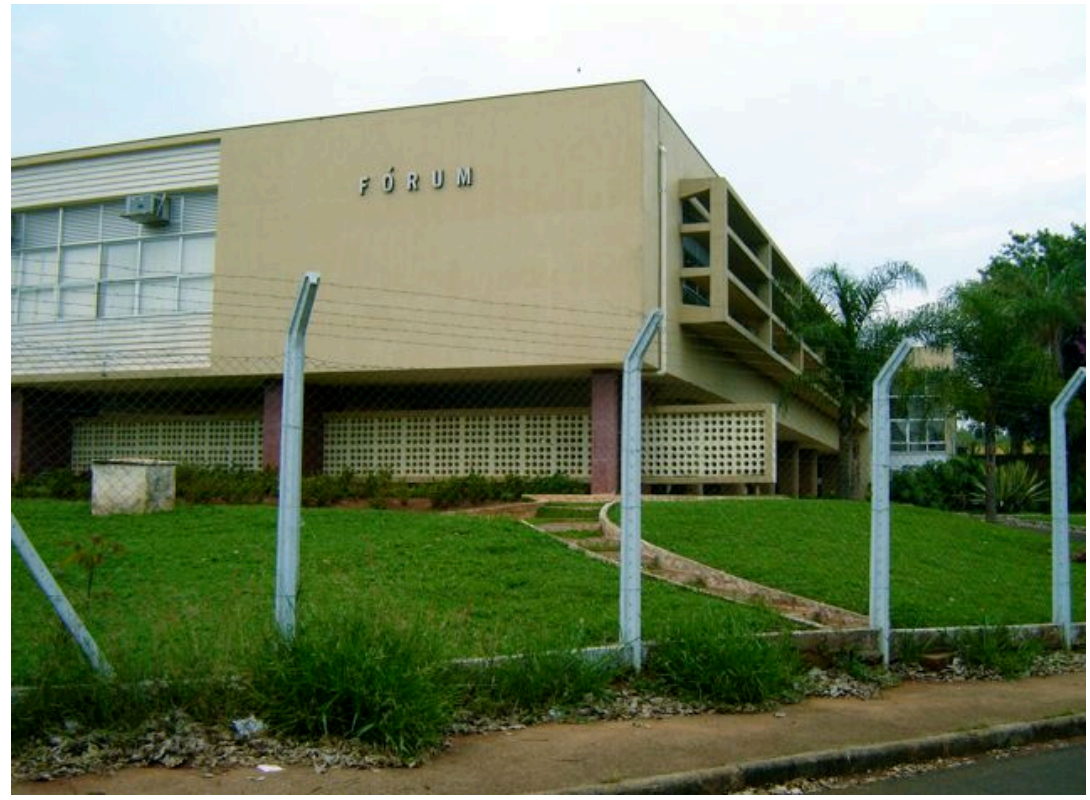

55. Fertiza. Administração. Fonte: NUTHAU-FAUeD / UFU 


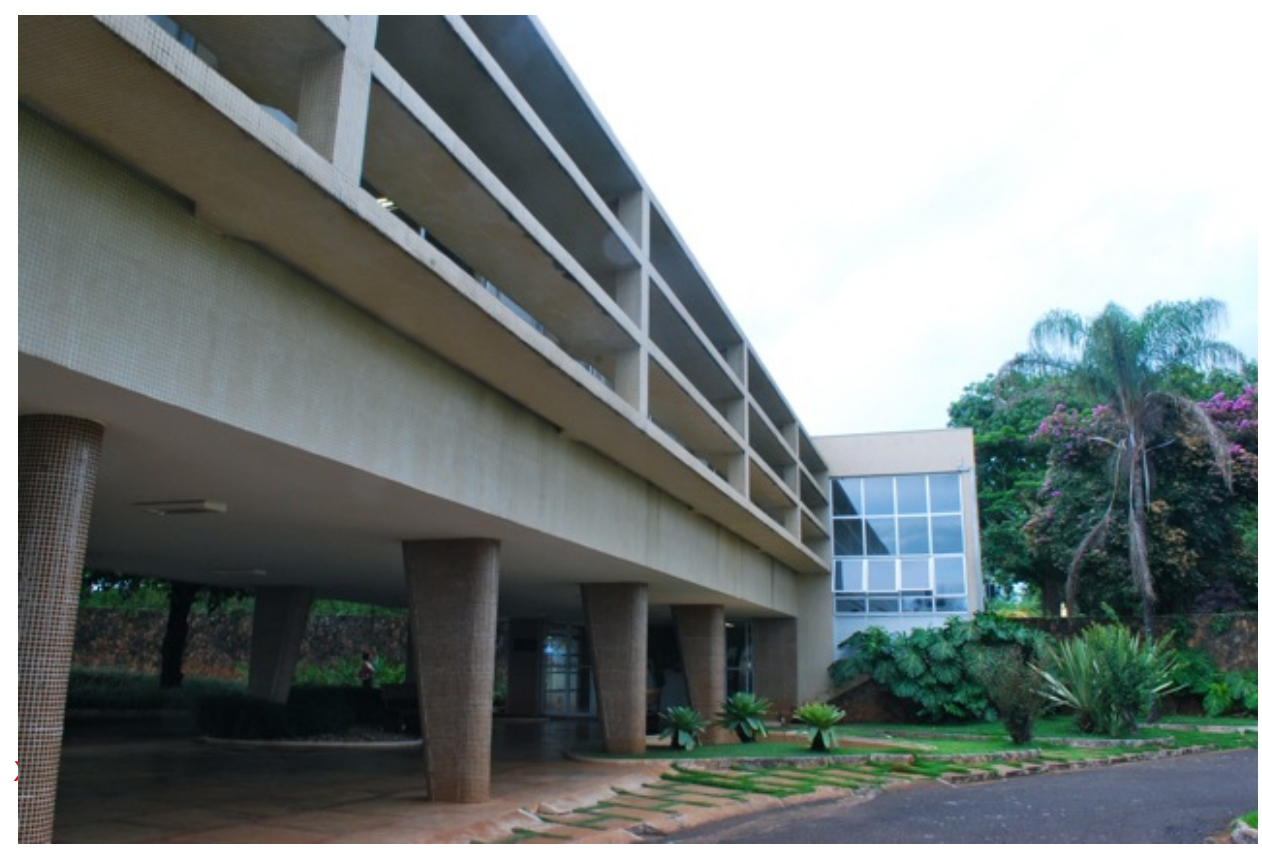

56. Fertiza. Administração. Fonte: NUTHAU-FAUeD / UFU

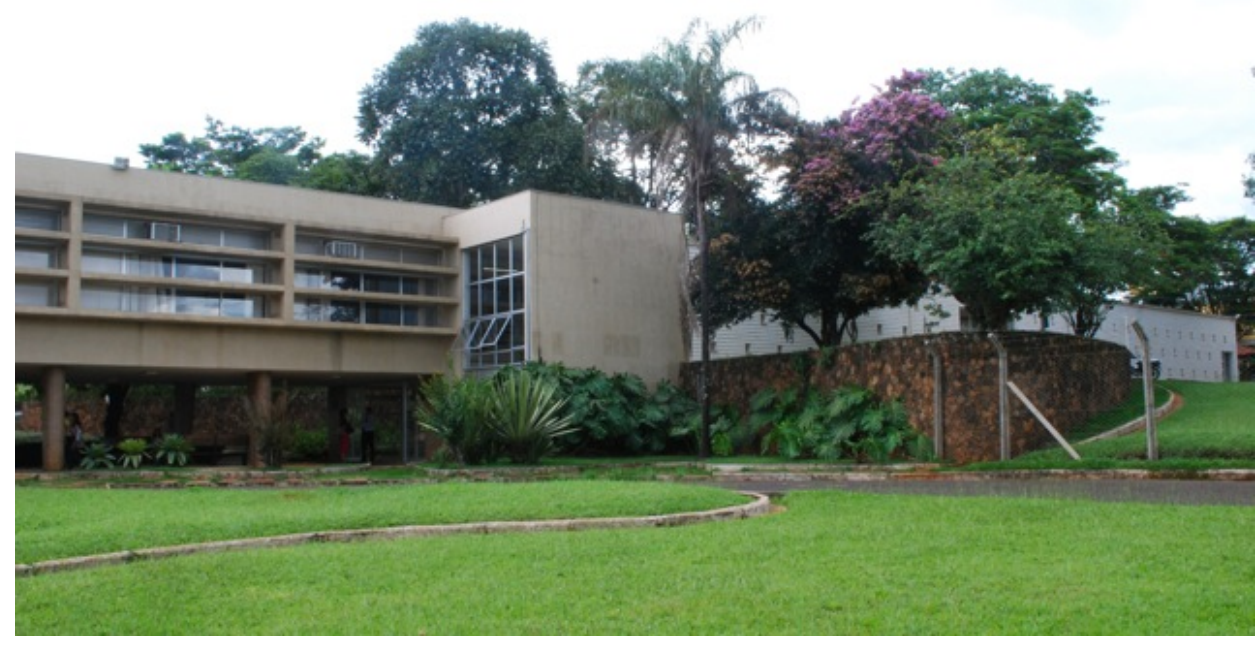

57. Fertiza. Administração. Fonte: NUTHAU-FAUeD /UFU

58. Fertiza. Administração. Pilotis. Fonte: NUTHAU-FAUeD I UFU

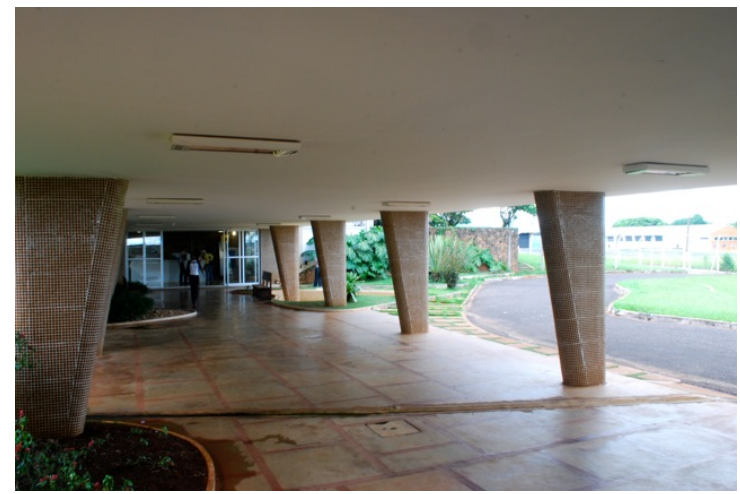




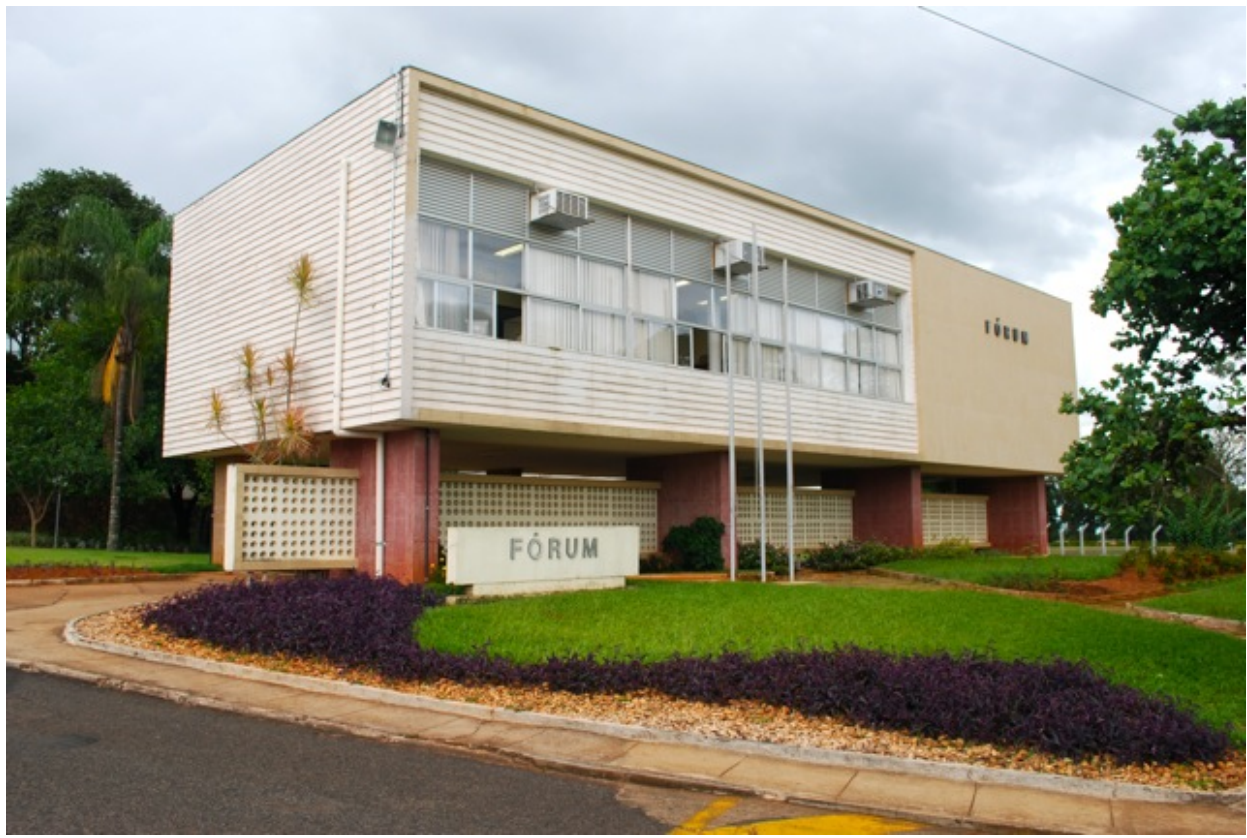

59. Fertiza. Administração. Fonte: NUTHAU-FAUeD / UFU.

60. Fertiza. Administração. Fonte: NUTHAU-FAUeD / UFU.

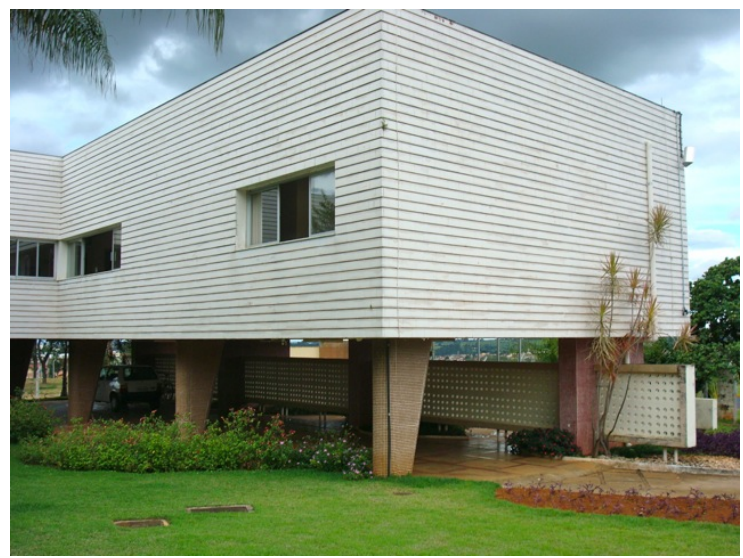

61. Fertiza.

Administração. Detalhe

Painel. Fonte: NUTHAU

FAUeD / UFU.

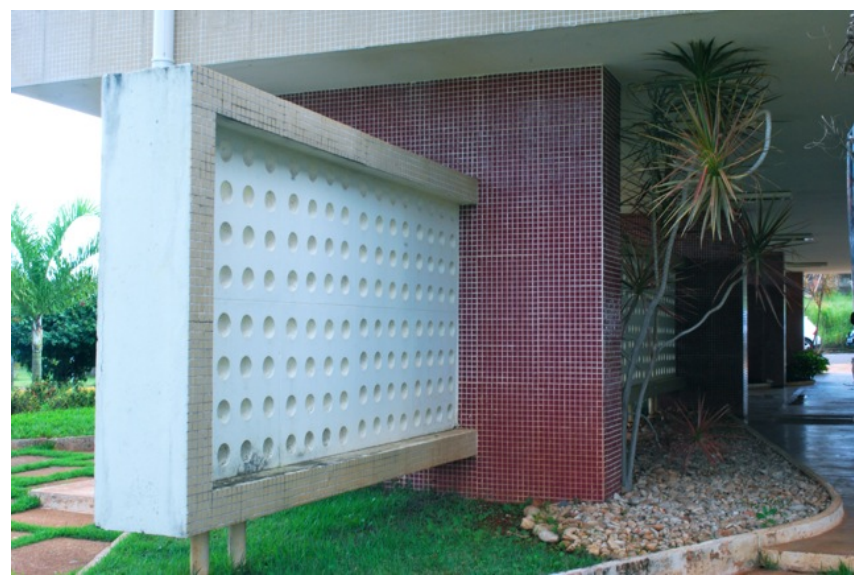


62. Fertiza. Administração. Fonte: NUTHAU-FAUeD / UFU.

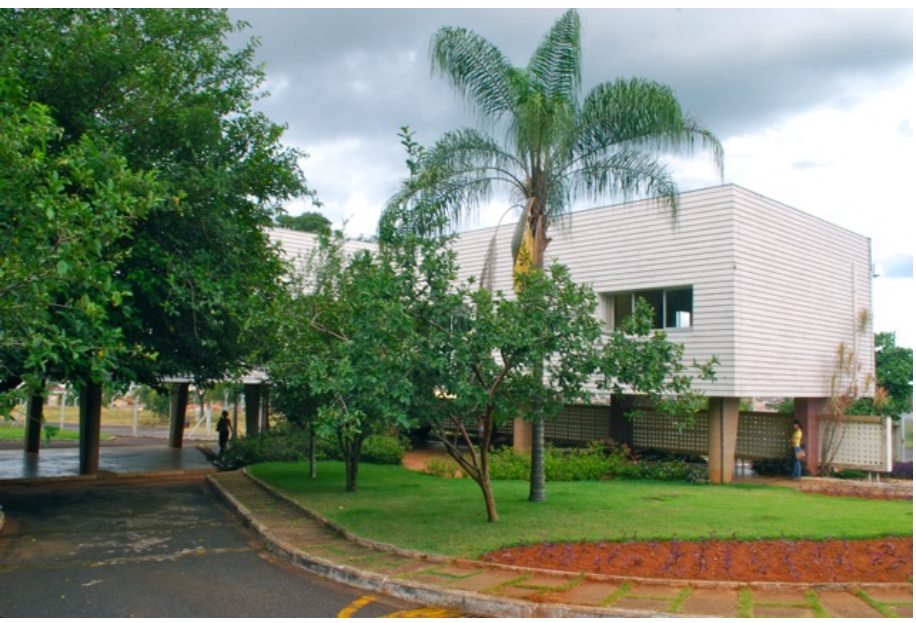

63. Fertiza.

Administração. Lago Artificial. Fonte: NUTHAUFAUeD / UFU

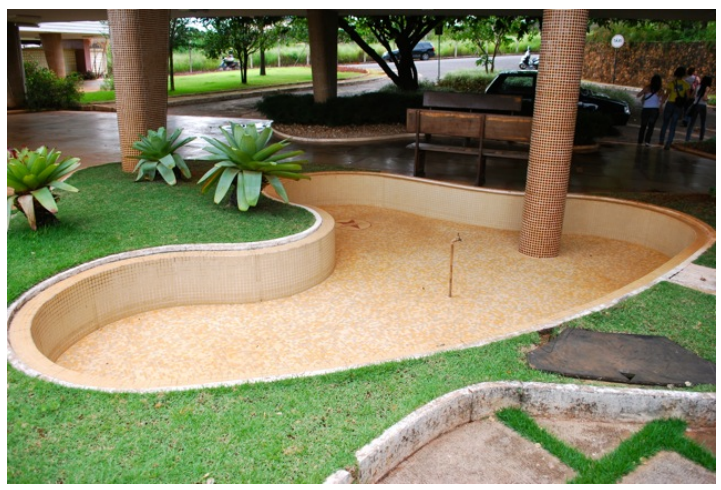

64. Fertiza. Administração. Fonte: NUTHAU-FAUeD / UFU.

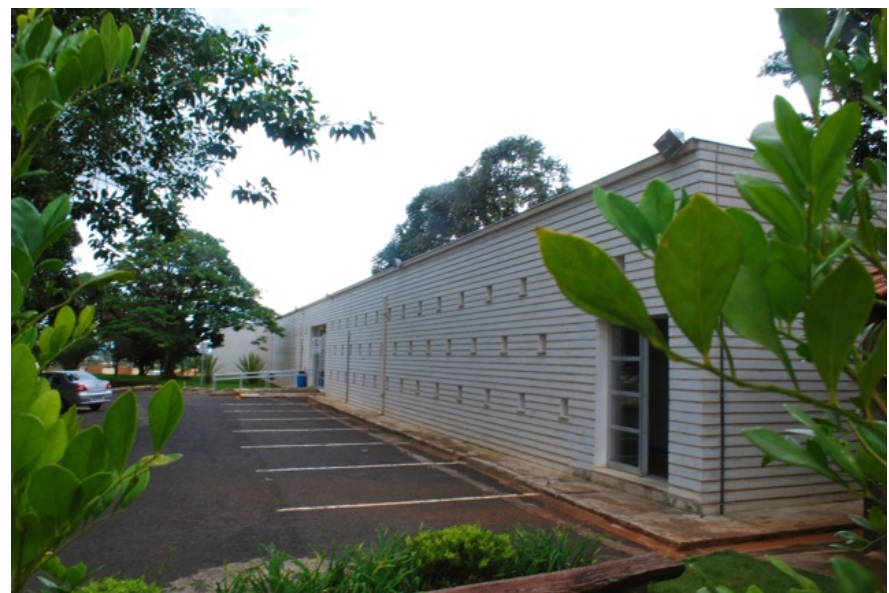

Atualmente, o complexo sedia algumas instalações da Codemig e do setor judiciário da cidade. $\mathrm{O}$ antigo edifício para vestiários e refeitórios agora acolhe a sede da Vara do Trabalho de Araxá, e a antiga administração da 
Fertiza, o Fórum da cidade. No antigo ambulatório, atualmente, está a administração da Codemig, e o antigo almoxarifado-oficina-garagem, tornou-se almoxarifado da mesma. A estação ferroviária é a Expominas, centro de exposições muito utilizado na cidade. Pelo uso frequente das instalações, os edifícios projetados por Raphael Hardy Filho encontram-se em bom estado de conservação, embora algumas alterações significativas do projeto original tenham sido feitas.

Pode-se dizer, que para as instalações da Fertiza, Hardy utilizou de diversos elementos difundidos pela arquitetura moderna brasileira naquele momento, sobretudo pela escola carioca. Além do uso do concreto armado, da planta livre que possibilitava maior liberdade na disposição dos cômodos internos, dos brise-soleil na contenção dos raios solares, o arquiteto emprega uma série de revestimentos, típicos da nova arquitetura nacional, como as pastilhas e as pedras naturais nos baldrames e muros de arrimo, o concreto e o tijolo deixados no seu aspecto natural. Em alguns casos, o arquiteto demonstra criatividade para ousar no desenho das fachadas, como no prédio para os vestiários e refeitórios. Merece destaque a forma harmoniosa como Hardy emprega todos esses revestimentos, dentro um desenho bastante coeso entre programa, funcionalidade, forma e estética. De forma mais específica, é possível enxergar, tanto no desenho sinuoso dos jardins quanto no formato irregular de alguns pilares, os diálogos feitos com a obra de Oscar Niemeyer como no desenho dos pilares - e Roberto Burle Marx, cujo projeto paisagístico para o Parque da Estância do Barreiro, acompanhou de perto.

O projeto de Raphael Hardy Filho para as Instalações Industriais da Fertiza, encontrado pela pesquisa do NUTHAU-FAUeD/UFU, é desconhecido pela historiografia da nossa arquitetura brasileira mas de extrema importância para o estabelecimento da arquitetura moderna em Araxá e no Triângulo Mineiro. A pesquisa do NUTHAU-FAUeD/UFU tem nos revelado que, na década 
de 1950, estava sendo introduzido na cidade, um acervo expressivo de obras modernas, a maioria de tipologia residencial, cujo arquiteto nativo, radicado em Belo Horizonte, Italo Pezzuti, é de grande importância. No ano de 1950, Araxá tem cerca de 18.515 habitantes $^{42}$, onde a comparação em número de habitantes com Uberaba, nesse ano, com mais de 60.000 habitantes, nos permite dizer que a arquitetura moderna foi recebida de forma significativa pela população local.

\footnotetext{
${ }^{42}$ Boletim do Departamento Estadual de Estatística, n. 35.
} 


\section{Os Arquitetos Residentes}

Trabalhos acadêmicos importantes já foram feitos sobre a produção de João Jorge Coury em Uberlândia, dentre os quais as dissertações de mestrado de Maria Elisa Guerra e Patrícia Pimenta Azevedo, ambas pela Escola de Engenharia de São Carlos, atual Instituto de Arquitetura e Urbanismo da Universidade de São Paulo. O intuito de ambas era pesquisar a difusão da arquitetura moderna na cidade através do arquiteto como um importante vetor. O trabalho de Guerra (1998) enfoca a atuação de Coury por meio de suas praças na região do Triângulo Mineiro, e o de Azevedo (1998), suas obras residenciais na cidade de Uberlândia. Tais trabalhos, somados à continuação da pesquisa acerca da produção de Coury pelo NUTHAU-FAUeD/UFU, têm demonstrado que este arquiteto foi um forte eixo de difusão da arquitetura moderna não só em Uberlândia, cidade em que se fixou, mas em outras cidades do Triângulo Mineiro e Alto Paranaíba.

Colega de turma de Raphael Hardy Filho - autor do Complexo Industrial da Fertiza em Araxá - na Escola de Arquitetura de Belo Horizonte (EABH), João Jorge Coury é o primeiro arquiteto a se fixar em Uberlândia, com escritório próprio. As pesquisas do NUTHAU-FAUeD/UFU ainda revelam que foi, provavelmente também, o primeiro arquiteto a se fixar na região com carreira ativa. Nascido em 25 de Novembro de 1908, natural de Abadia dos Dourados, outra cidade triangulina, João Jorge Coury se muda para Uberlândia pouco tempo depois de completar o curso de arquitetura, onde já moravam sua irmã e cunhado. Seus pais moravam em Araguari, cidade muito próxima. Coury completa o curso em 1937, mas cola grau em 1940, ano em que monta seu atelier em Uberlândia. A partir da década de 1950, esse arquiteto será o profissional responsável por introduzir de forma efetiva, a arquitetura moderna nessa cidade. 
Quando estudante, o arquiteto esteve presente em várias atividades: foi um dos fundadores do Diretório Acadêmico da Escola de Arquitetura; fez parte da criação e redação da revista "Arquitetura", um mensário oficial dos alunos da escola; foi expositor e organizador do Salão Bar Brasil, em Belo Horizonte, também conhecido como "Semana de Arte Moderna Mineira"; e membro da juventude do Partido Comunista Brasileiro. (AZEVEDO, 1998)

Politicamente, Coury era ativo em Uberlândia. Afinado com as questões sociais, teve participação intensa no meio cultural. Participou da criação de sindicatos, foi um dos fundadores da Associação de Engenheiros, Químicos e Agrônomos e da Coperativa de Fruticultores. Ajudou na criação da UESU (União de Estudantes Secundaristas de Uberlândia). Foi preso político em Belo Horizonte, em 1937, e em 1964, em Uberlândia, com o Golpe Militar, ficando detido por três meses na Base da Aeronáutica em Lagoa Santa - MG. Tanto Guerra (1998) quanto Azevedo (1998) apontam para o fato de que Uberlândia era um ponto importante de atuação do Partido Comunista Brasileiro, tendo grande número de integrantes do partido, daí ter recebido a alcunha de “Moscou Brasileira”, nos anos de 1950.

Pessoa educada, inteligente e culta, segundo depoimentos, era muito bem relacionado com todas as camadas sociais e defendia o movimento de massas, como ideal de luta e consciência política. [...] Sua atuação profissional era compartilhada com sua atuação política. (GUERRA, 1998, p.91)

Azevedo (1993) nos conta que Coury foi definido como um mestre por vários de seus auxiliares-discípulos, que trabalharam como desenhistas no seu atelier e mais tarde foram estudar em faculdades de arquitetura. Alguns exemplos são: Milton Leite Ribeiro, que atuou em Uberlândia; Ivan Cupertino, que atuou em Belo Horizonte; João Alves Pimenta e Fernando Galvão que 
atuaram em Goiânia; Miguel Juliano que atuou em São Paulo e projetou também em Uberlândia; etc. Para Azevedo (1998, p.69), Coury foi mestre

[...] tanto no sentido afetivo, quanto no de definir aquela pessoa que orienta e abre novas visões de mundo, que mostra ao mesmo tempo os problemas sociais e políticos e a vanguarda na arquitetura. Coury não deixou textos sobre sua arquitetura, nem sobre sua visão da arquitetura brasileira, mas em seu escritório exigia um mínimo de conhecimento teórico dos seus estagiários.

Miguel Juliano, um de seus desenhistas, depois formado pela Faculdade de Arquitetura Brás Cubas (1973), projetou ainda antes de formado, o Edifício da Sociedade Médica de Uberlândia, em 1953, projeto onde segue os postulados de Le Corbusier, utiliza da planta livre em estrutura de concreto armado, permitindo a elaboração de esquadrias com panos de vidro na fachada posterior, à sudeste, e fazendo uso de brises para proteção dos raios solares à noroeste, além de utilizar de pilotis a fim de se conseguir uma fluidez espacial com o ambiente público. (AZEVEDO, 1998) O térreo de pilotis foi fechado em reforma de 1992, além de diversas outras modificações já sofridas e que têm sido documentadas pela pesquisa do NUTHAU-FAUeD/UFU.

A construção de um edifício institucional moderno no início da década de 1950, situado na área central de Uberlândia, contribuiu para a recepção da nova arquitetura pelos moradores da cidade, auxiliada nesse processo pela imprensa local, a qual divulgava a obra como "majestosa" e "suntuosa", obra que "simboliza realmente o espírito Uberlandense" ${ }^{\text {"3 }}$.

Sobre o tempo em que trabalhou como desenhista no escritório de João Jorge Coury, antes de se mudar para São Paulo, disse o arquiteto:

\footnotetext{
${ }^{43}$ UBERLÂNDIA llustrada. Uberlândia, n. 20, dez. 1955. APU.CPJA
} 
Vivia-se esse clima e esse clima era vivido naquele pequeno atelier, ponto de encontro de uns poucos intelectuais, onde eu também fui tomando contato com os livros e as ideias. Já na primeira semana foi me dada uma lista de livros, na sua maioria, de estudos sociais, "que todo mundo devia ler, no mínimo". Recordo-me que o primeiro da lista era o Max Beer. Nas estantes do escritório, livros de arte, de arquitetura, dos quais dois me atraíram de pronto: La Ville Radieuse e Brazil Builds. (JULIANO, 1980 apud AZEVEDO, 1998, p.69)

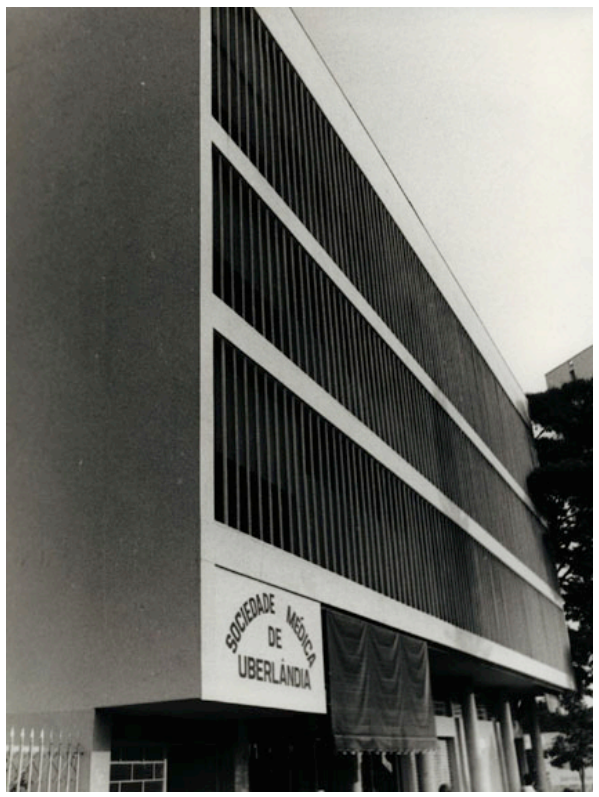

65. Sociedade Médica de Uberlândia. Situação atual.

Fonte: CDHIS/UFU -

NUTHAU- FAUeD / UFU

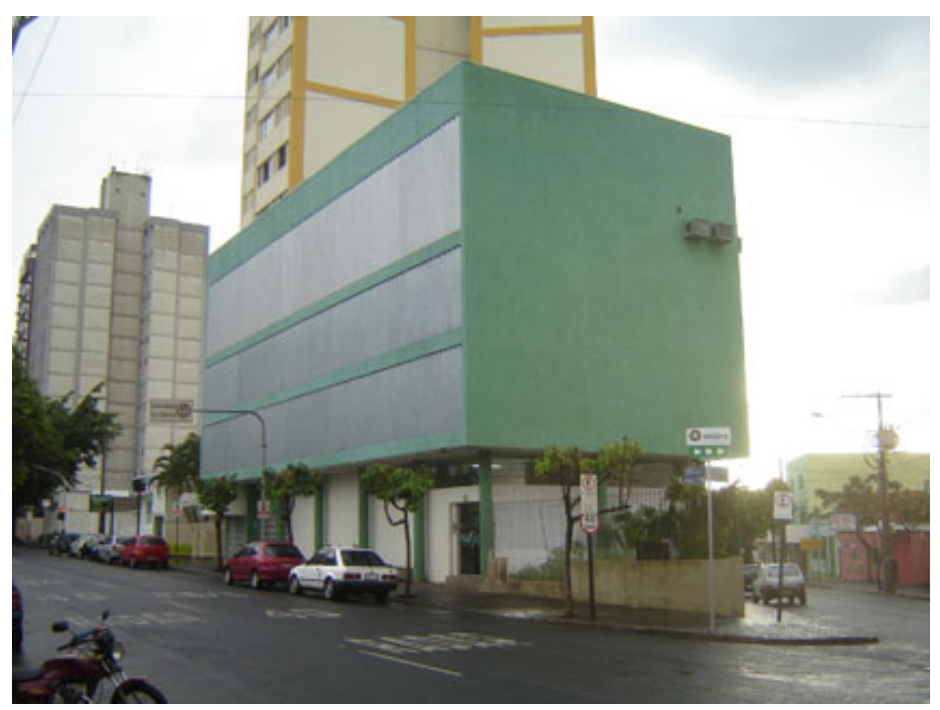

66. Sociedade Médica de Uberlândia. Situação atual. Fonte: NUTHAUFAUeD / UFU 
Coury teve o início de sua atuação profissional em Goiandira e Catalão, cidades do estado de Goiás, próximas à Uberlândia. $\mathrm{O}$ arquiteto teve uma clientela significativa em Goiás, onde projetou edifícios na capital Goiânia, em Anápolis, Itumbiara, etc. Em toda sua carreira, Coury fez projetos de diversas tipologias, residências, comércios, hospitais, indústrias, projetos urbanísticos, além de dar tratamento especial no paisagismo de seus projetos. Quando abre seu escritório, em 1940, sua produção ainda segue o estilo eclético, assumindo a linguagem moderna somente a partir de 1950. (AZEVEDO, 1998)

Azevedo (1998) sublinha que Coury era um arquiteto que possuía vínculos nas capitais do país, mantinha contato com seus antigos desenhistas que foram estudar em Belo Horizonte e São Paulo, e que esses diálogos teriam reforçado a decisão do arquiteto em assumir definitivamente o moderno em suas obras. Também, há de se considerar que a arquitetura moderna já havia passado por Warchavchik, a construção do Ministério da Educação e Saúde em fins da década de 1930 e a mostra Brazil Builds publicada pelo MOMA em 1943. Também, em 1951, acontece a I Bienal de Arquitetura em São Paulo, a Pampulha tinha sido concluída alguns anos antes, e em toda a década de 1950, a arquitetura moderna brasileira é pauta de discussão no Brasil e também na crítica internacional.

Nesse momento, lembramos que a construção de Brasília estrutura uma nova dinâmica construtiva na região, que aquece o mercado da construção civil, avançando as possibilidades técnicas construtivas. Em meados da década de 1950, Coury trava uma parceria importante com o engenheiro Rodolfo Uchoa, nascido no Chile e graduado pela Universidade do Chile em 1947. Uchoa conhece Coury quando em 1953 constrói a SOTREC (Sociedade Anônima de Tratores e Equipamentos) em Uberlândia, mudando-se para a cidade um ano depois, associando-se ao escritório de Coury onde permanece 
até o fim da década de 1960. No escritório, Rodolfo Uchoa passa a ser responsável pelos elaboração dos projetos estruturais. (AZEVEDO, 1998)

$\mathrm{Na}$ sua produção moderna residencial, vê-se uma arquitetura preocupada com a distribuição funcional da planta, fazendo uso de corredores e pátios internos para melhor ventilação e conforto térmico. Dá tratamento especial às fachadas, compostas por varandas ajardinadas, em vários casos, dispondo de elementos de proteção solar como brises, painéis vazados, cobogós, treliças, que ajudavam também na preservação da intimidade familiar, posto que em algumas residências esses espaços vão se tornando mais integrados com o exterior e o espaço público.

$\mathrm{Na}$ medida em que se avançam as possibilidades tecnológicas e construtivas da região, Coury explora seu repertório formal, refletido na utilização de rampas, coberturas em lajes planas ou inclinadas e impermeabilizadas. Nas coberturas, também faz uso da platibanda e da telha cerâmica aparente em alguns projetos. Na volumetria, explora as formas puras, utiliza de altos e baixos relevos, cheios e vazios, faz uso de variados tipos de revestimentos, explorando cores e texturas dos materiais encontrados facilmente na região, como os seixos rolados, pedras naturais, pastilhas, azulejos, etc. Apareciam, por vezes nos jardins internos ou nas paredes cegas da fachada frontal, painéis em mosaico de vidro, elaborados por dois artistas plásticos atuantes em Uberlândia, Geraldo Queiroz $^{44}$ e J. Moraes, revelando que aqui também aparecia uma das principais características da arquitetura moderna brasileira que é a síntese das artes.

Podemos perceber, uma maturidade revelada pelo equilíbrio do arquiteto, na configuração da planta funcionalista, na valorização

\footnotetext{
${ }^{44}$ Ver mais em: MACHADO JUNIOR, Juscelino Humberto Cunha. A poética do vernáculo: os painéis de Geraldo Queiroz no Triângulo Mineiro. 2010. 328 f. Dissertação (Mestrado)-Universidade Federal de Uberlândia, Uberlândia, 2010.
} 
do micro-clima proporcionado pelos jardins internos que promove a interação com a natureza, na relação da edificação no lote que integra frente-fundo, na valorização da composição volumétrica de todas as elevações e na preocupação com o uso das técnicas construtivas. (AZEVEDO, 1998, p.156)

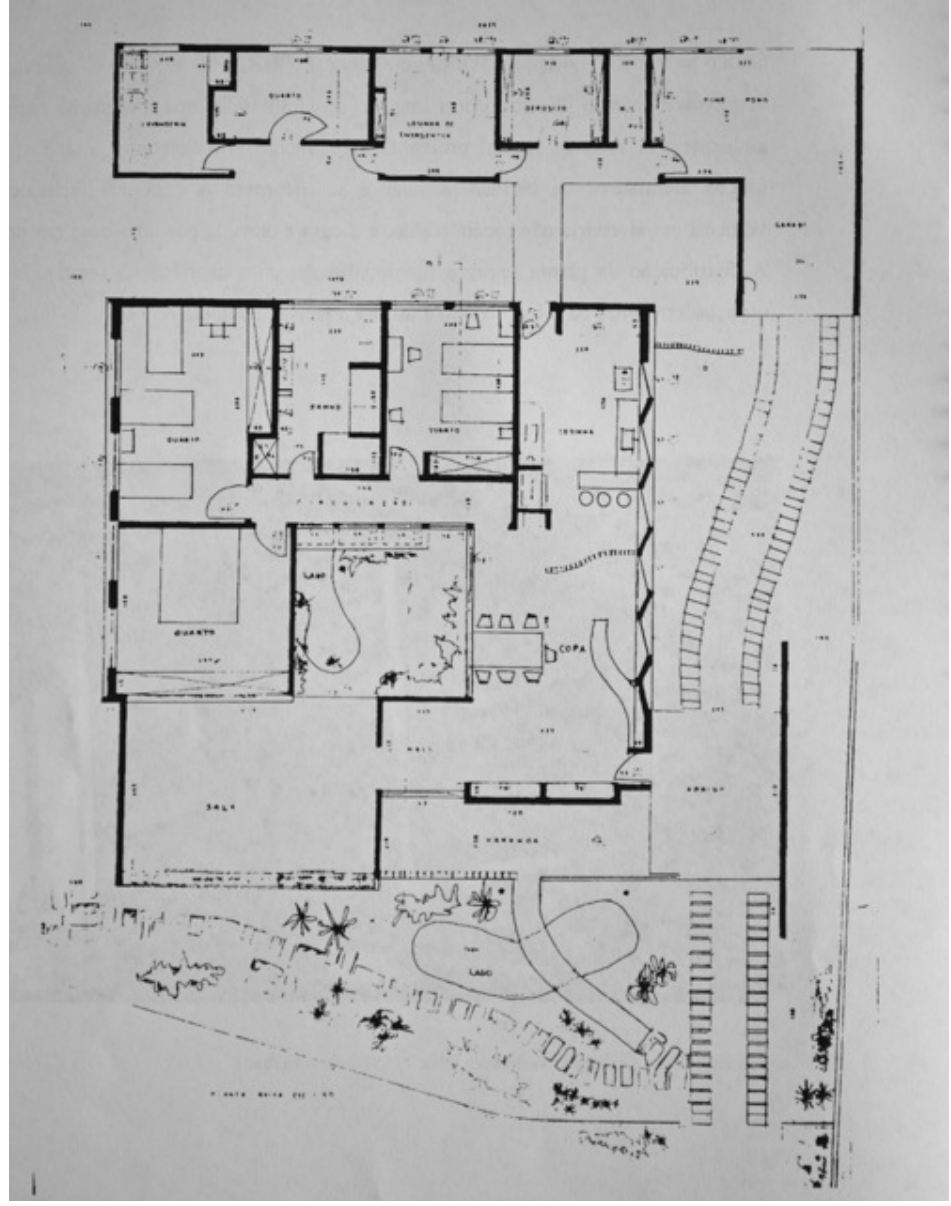

67. Residência Waldemar Silva. Planta. Arquiteto João Jorge Coury. Fonte: AZEVEDO, 1998

68. Residência Waldemar Silva Arquiteto João Jorge Coury. Fonte: Arquivo Pessoal de Patrícia P. Azevedo. NUTHAU-FAUeD / UFU.

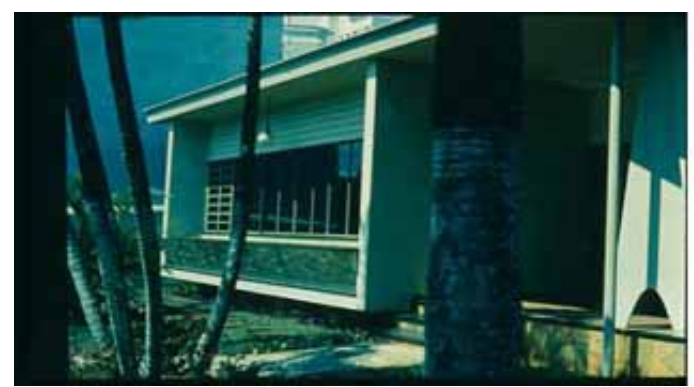


69. Residência Waldemar Silva Arquiteto João Jorge Coury.

Painel de José Moraes. Fonte: Arquivo Pessoal de Patrícia P. Azevedo. NUTHAU-FAUeD / UFU.
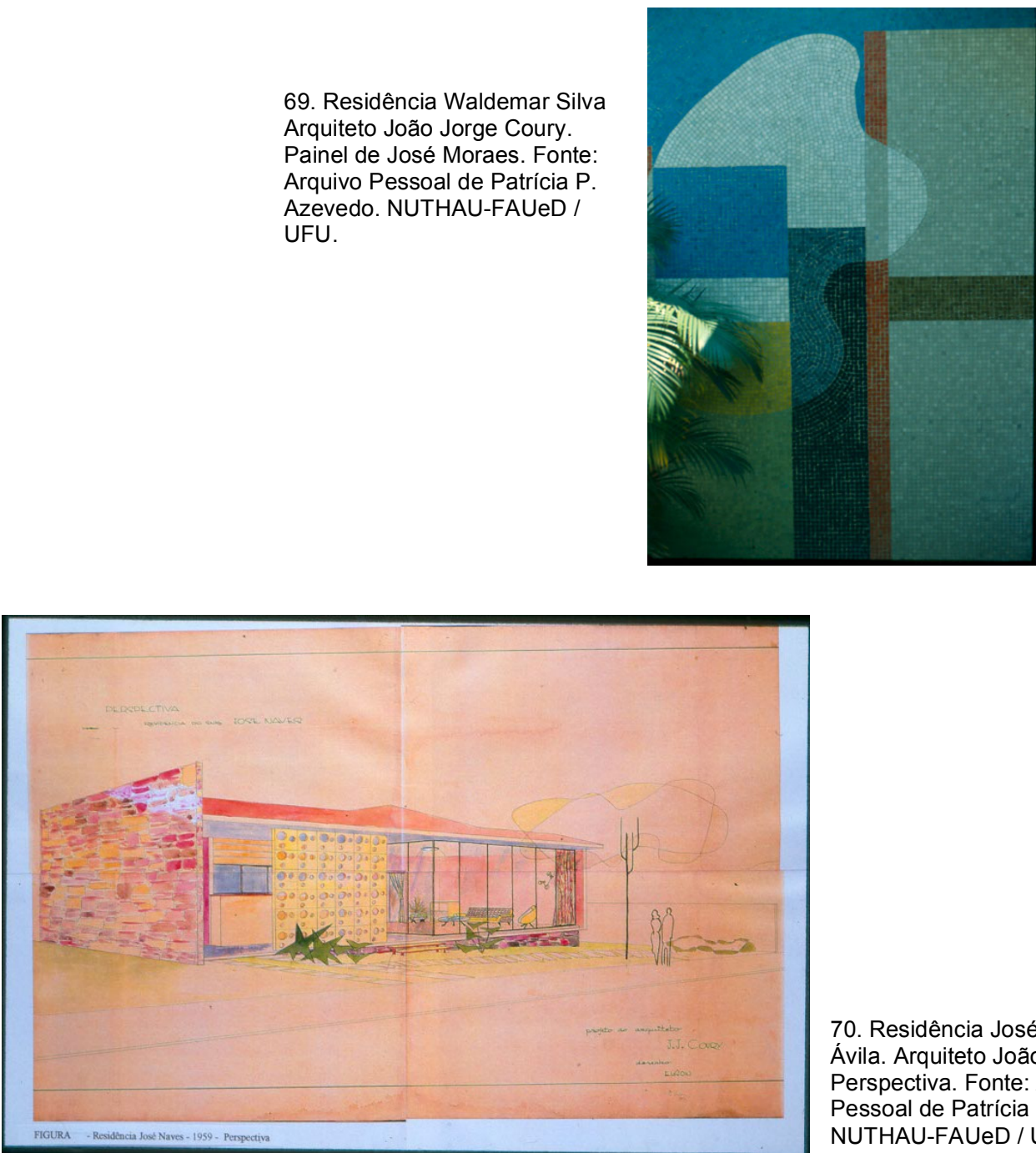

70. Residência José Naves de Ávila. Arquiteto João Jorge Coury. Perspectiva. Fonte: Arquivo

Pessoal de Patrícia P. Azevedo. NUTHAU-FAUED / UFU.

71. Residência Sebastião Caparelli. Arquiteto João Jorge Coury. Pergolado. Fonte: Arquivo Pessoal de Patrícia P. Azevedo. NUTHAU-FAUED / UFU.

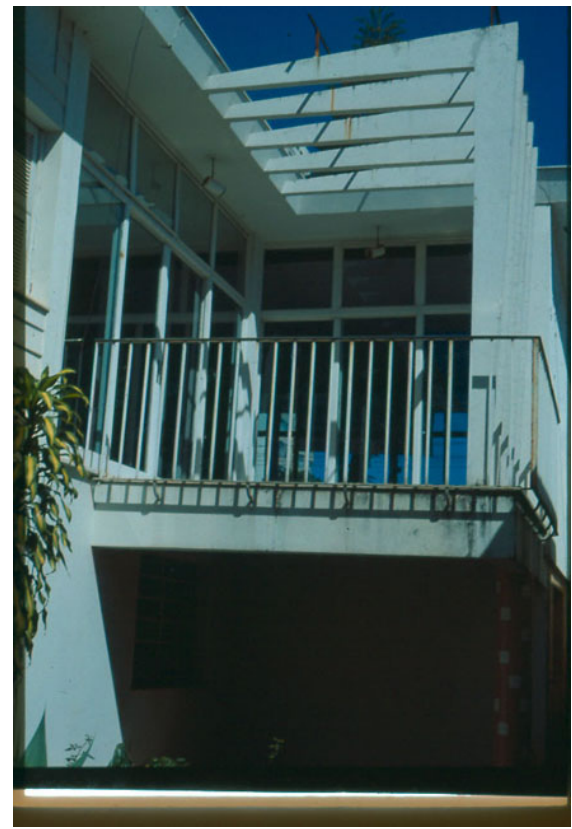




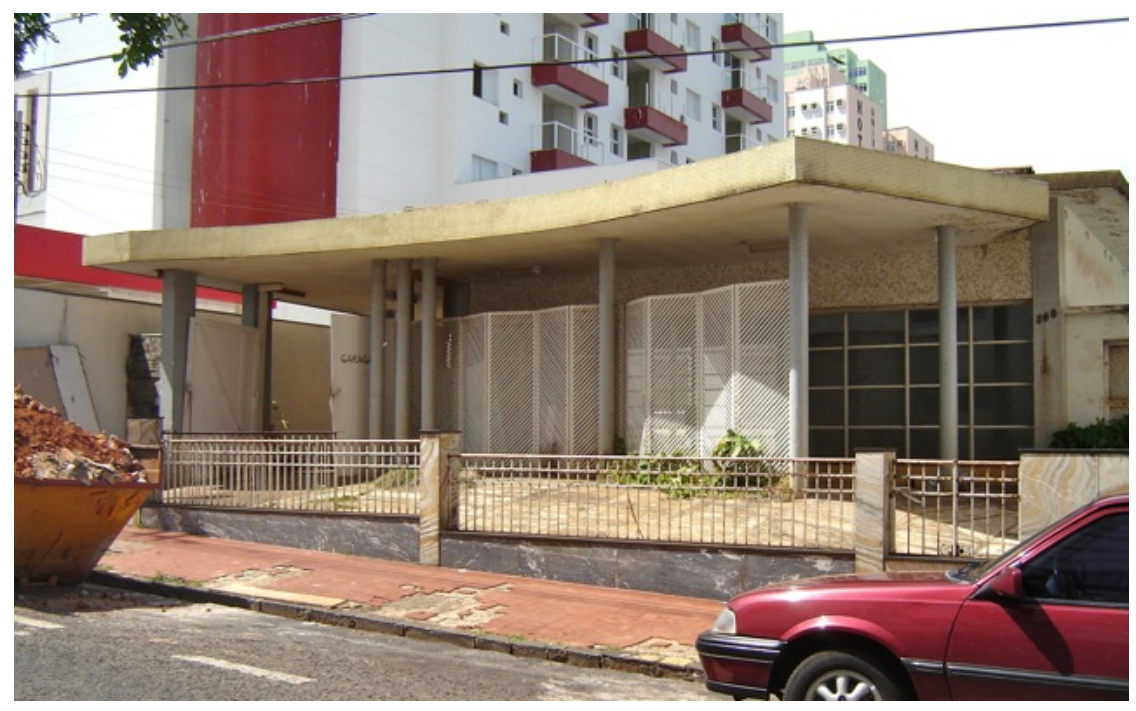

72. Residência Benedito Modesto. Arquiteto João Jorge Coury. Fonte: NUTHAUFAUeD / UFU.

Coury também tem um acervo significativo de obras públicas, foi responsável pelo projeto de diversas praças em Uberlândia e em outras cidades do Triângulo Mineiro, como em Araguari, Ituiutaba e Tupaciguara, e no Estado de Goiás, como em Itumbiara, etc. ${ }^{45}$ A pesquisa do NUTHAU-FAUeD/UFU tem mostrado que o arquiteto ainda projetou diversas tipologias em outras cidades do Triângulo Mineiro, sendo o responsável pela introdução do moderno em cidades menores da região, como é o caso de Tupaciguara, cujo acervo arquitetônico moderno parece ter Coury como único arquiteto. Nessa cidade, projetou a Residência João de Oliveira Prudente, a Residência da Sra. Susidally Pina Pereira, a Fábrica de Doces Angorá e a Igreja Nossa Senhora de Fátima,

\footnotetext{
${ }^{45}$ Sobre as praças modernas de Coury, recomendamos: GUERRA, M. E. (1998). As Praças Modernas de João Jorge Coury no Triângulo Mineiro. São Carlos, Dissertação (Mestrado), EESC USP.
} 
todos projetos da década de 1950 . No final da década de 1960, projetou o edifício do atual Fórum de Ituiutaba.

73. Ig. N. S. De Fátima. Tupaciguara. Arquiteto João Jorge Coury. Fonte: NUTHAUFAUED / UFU
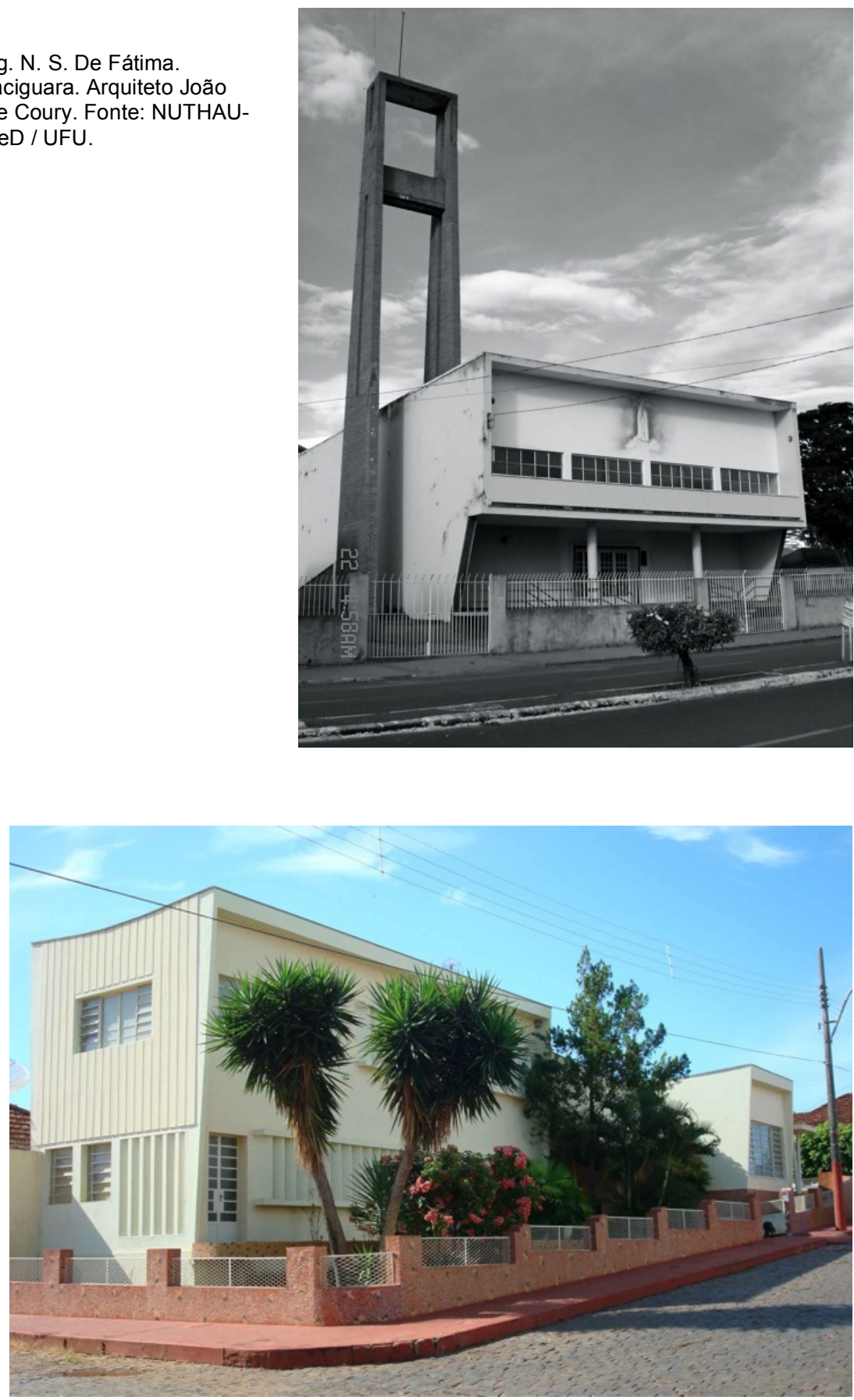

74. Susidally Pina Pereira,Tupaciguara. Arquiteto João Jorge Coury. Fonte: NUTHAU-FAUED / UFU. 
Pelo avanço das possibilidades construtivas com Brasília, sua produção vai refletir as novas tecnologias no decorrer da década de 1960, perdendo aos poucos aquela característica "artesanal" citada por Laurentiz (1992), fruto de uma composição dependente das possibilidades técnicas que a região possuía no início dos anos de 1950, descrevida por Nelson Cupertino como "pálidos reflexos da imaginária perspectiva, capazes de serem executados em material tosco e abundante." ${ }^{46}$ São variações percebidas, por exemplo, nas residências Airton Borges (1960), Diogo Oliveira (1964) e Duarte Ulhoa Portilho (1968).

75. Residência Dr. Duarte Ulhôa Portilho. Fonte: Arquivo Pessoal de Patrícia P. Azevedo. NUTHAUFAUeD / UFU.

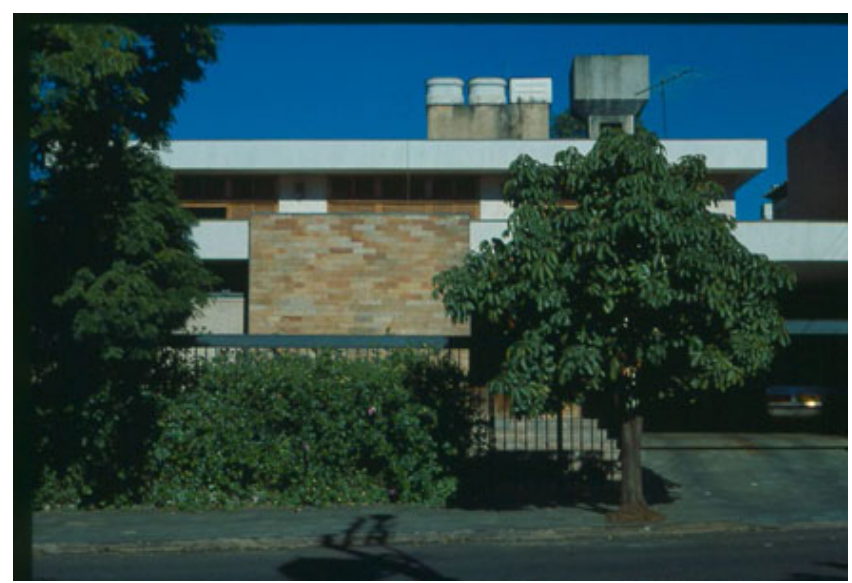

\footnotetext{
${ }^{46}$ CUPERTINO, Nelson. O Sonho do Arquiteto. Correio de Uberlândia, Uberlândia, 8 Jan. 1970.
} 
76. Residência Diogo Oliveira Banco contínuo. Fonte: Arquivo Pessoal de Patrícia P Azevedo. NUTHAU-FAUeD / UFU.

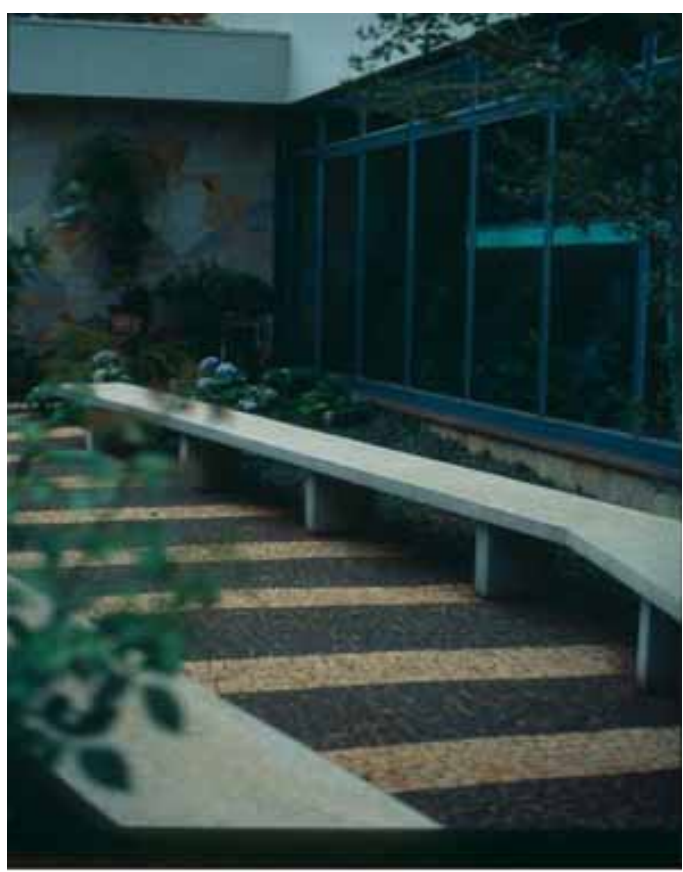

77. Residência Airton Borges da Silva. Jardim Interno. Fonte: Arquivo Pessoal de Patrícia P. Azevedo. NUTHAU-FAUeD / UFU.

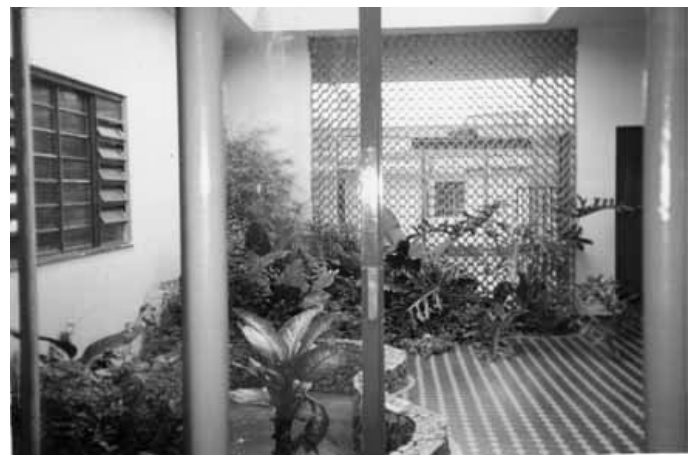

Nesse primeiro processo de difusão do moderno, a Escola de Arquitetura de Belo Horizonte (EABH) terá papel fundamental, formando, assim como Coury, diversos arquitetos que irão atuar na região e que serão também importantes nesse momento de primeiras inserções do moderno nas cidades do Triângulo Mineiro e Alto Paranaíba.

Atual Escola de Arquitetura da Universidade Federal de Minas Gerais, a EABH foi fundada em 1930 por um grupo de intelectuais e profissionais da capital mineira que desejavam criar uma instituição de ensino superior para formação de profissionais na área das artes, como técnicos de arquitetura, 
decoradores, escultores e pintores. Argumentava-se que "Belo Horizonte encontrava-se num contexto de significativo crescimento, justificando assim, de grande importância a formação de profissionais de arquitetura e planejamento urbano" (LEMOS; DANGELO; CARLASALADE, 2011)

Tendo sua aula inaugural em 2 de Fevereiro de 1931, a EABH era a primeira escola de arquitetura independente do país, isto é, fundada sem vínculos com nenhuma outra escola de Belas Artes ou Politécnicas, modelos vigentes até então. Luiz Signorelli, autor do Grande Hotel e Termas do Barreiro de Araxá foi o primeiro diretor da escola. Mais tarde, no ano de 1940, a EABH foi incorporada à um instituto de Belas Artes, período em que Juscelino Kubitschek era prefeito de Belo Horizonte e seu primo João Kubitschek, diretor da escola. Em 1944, passa a ter reconhecimento federal, tendo seus diplomas válidos em todo território nacional. Em 1946, a Escola de Arquitetura se desvincula do Instituto de Belas Artes, sendo incorporada à Universidade Federal de Minas Gerais. (LEMOS; DANGELO; CARLASALADE, 2011)

O currículo da Escola apontava para uma formação abrangente, considerando o arquiteto, também um artista, mas que deveria ter conhecimento consistente das técnicas da construção. A escola objetivava formar profissionais que detivessem conhecimentos em diversas áreas do saber. Assim, segundo o professor João Kubitschek:

[...] havia a necessidade de formar elementos dotados de qualidades indispensáveis ao verdadeiro arquiteto, que deve ser, ao mesmo tempo, um homem de ciência, quando lança mão de seus conhecimentos de física aplicada e de higiene; sociólogo e historiador, quando examina as necessidades das populações e se utiliza do vasto patrimônio da arquitetura passada; economista e artista, afinal, quando procura soluções para o angustiante problema do proletariado e estuda as condições locais para os partidos de que resultam o conveniente, o confortável e o belo. 
(KUBITSCHEK, 1946 apud LEMOS; DANGELO; CARLASALADE, 2011)

Um reflexo da inserção de Minas no contexto cultural de produção moderna no país foi a adição, em 1944, da disciplina "Arquitetura no Brasil" cuja proposta "contemplava uma interpretação do modernismo nacional dentro da nossa realidade". (LEMOS; DANGELO; CARLASALADE, 2011) Raphael Hardy Filho, que se tornou professor da escola depois de graduado - assim como diversos desses primeiros alunos como Shakespeare Gomes e Sylvio Vasconcellos - relata que a escolha pelo moderno nas disciplinas de projeto, na sua época de estudos, era recebida sem problemas, ainda que a produção da equipe docente da escola nesse período não respondesse à vanguarda arquitetônica. Pedia-se, no entanto, a justificativa das preferências e soluções adotadas, atribuindo importância às discussões que envolviam tais escolhas.

Nós jovens ficamos empolgados com Le Corbusier, e com outros arquitetos europeus, e os professores de projeto davam um tema e nós fazíamos modernista, eles ficavam com medo de discutir porque eles não entendiam patavina [...] nós sofremos muito a influência dos arquitetos, principalmente europeus, e lógico nós tínhamos estudado o Art Nouveau, mas abandonamos o Art Nouveau justamente por causa dos slogans, principalmente por causa de Le Corbusier. "a casa é uma máquina de morar", nós estávamos querendo fazer máquinas. ${ }^{47}$

Dos arquitetos atuantes no Triângulo Mineiro e Alto Paranaíba, dos até então já encontrados pela pesquisa do NUTHAU-UFU, a grande maioria é formada pela $\mathrm{EABH}$, onde a supremacia da escola só parece ceder espaço à outras faculdades a partir da década de 1960, onde encontramos arquitetos

\footnotetext{
${ }^{47}$ Raphael Hardy Filho em depoimento dado à Azevedo (1998), em 09/04/1996.
} 
formados, por exemplo, pela Universidade de Brasília e Mackenzie. São arquitetos formados pela EABH e que contribuíram para a produção moderna da região: Shakespeare Gomes (1937), Raphael Hardy Filho (1937), João Jorge Coury (1940), José Bellini dos Santos Filho (1950), Jefferson José Lodi (1951), Italo Pezzuti (1952), Ulpiano Nunes Muniz (1952), Helvio Felice (1954), Alceglan Saldanha Monteiro da Silva (1959), Fernando de Oliveira Graça (1959), Osvaldo Teixeira (1959), Natalino David Thomaz (1960), Ivan Cupertino Rodrigues (1962), Cádmo de Paula (1963), José Carlos Laender de Castro (1963), Marcelo Gusmão Machado (1963), Arlen José Simão (1964), Sidônio Márcio Alves Porto (1964), Freuza Maria Zechmeister (1964), Wagner Schroden (1966), César Augusto Simão (1968) e Paulo Henrique Carrara Arantes (1972).

Em Araxá, além do Complexo Industrial da Fertiza, projetado por Hardy, graduado e depois docente da Escola de Arquitetura, outro arquiteto também formado por essa escola se destaca na cidade. Ítalo Pezzuti, que cola grau em 1952, natural de Araxá, atua com escritório próprio na capital Belo Horizonte, onde em 1957 projetou o prédio da reitoria da Universidade Federal de Minas Gerais - UFMG, ao lado dos arquitetos Eduardo Mendes Guimarães Jr. e Gaspar Ferdinando Garreto. A partir da década de 1950, Pezzuti elabora diversos projetos na sua cidade natal, principalmente residências, sendo nesse período o arquiteto responsável pelo maior acervo moderno da cidade. Nas visitas feitas pelos pesquisadores do NUTHAU-FAUeD/UFU, foram encontrados diversos projetos seus no Banco de Obras da cidade, durante as décadas e 1950, 1960 e 1970. Mais tarde, Pezzuti cria uma parceria com Marcelo Gusmão Machado, também natural de Araxá, graduado na EABH em 1963. Gusmão Machado inicia sua carreira na capital mineira, onde trabalhou por um período no escritório de Pezzuti, com quem elaborou alguns projetos ao voltar para a cidade, dentre eles, o Clube Araxá, no fim da década de 1960. 
78. Edifício São Jorge. Arquiteto Italo Pezzuti. Fonte: NUTHAU-FAUED / UFU.
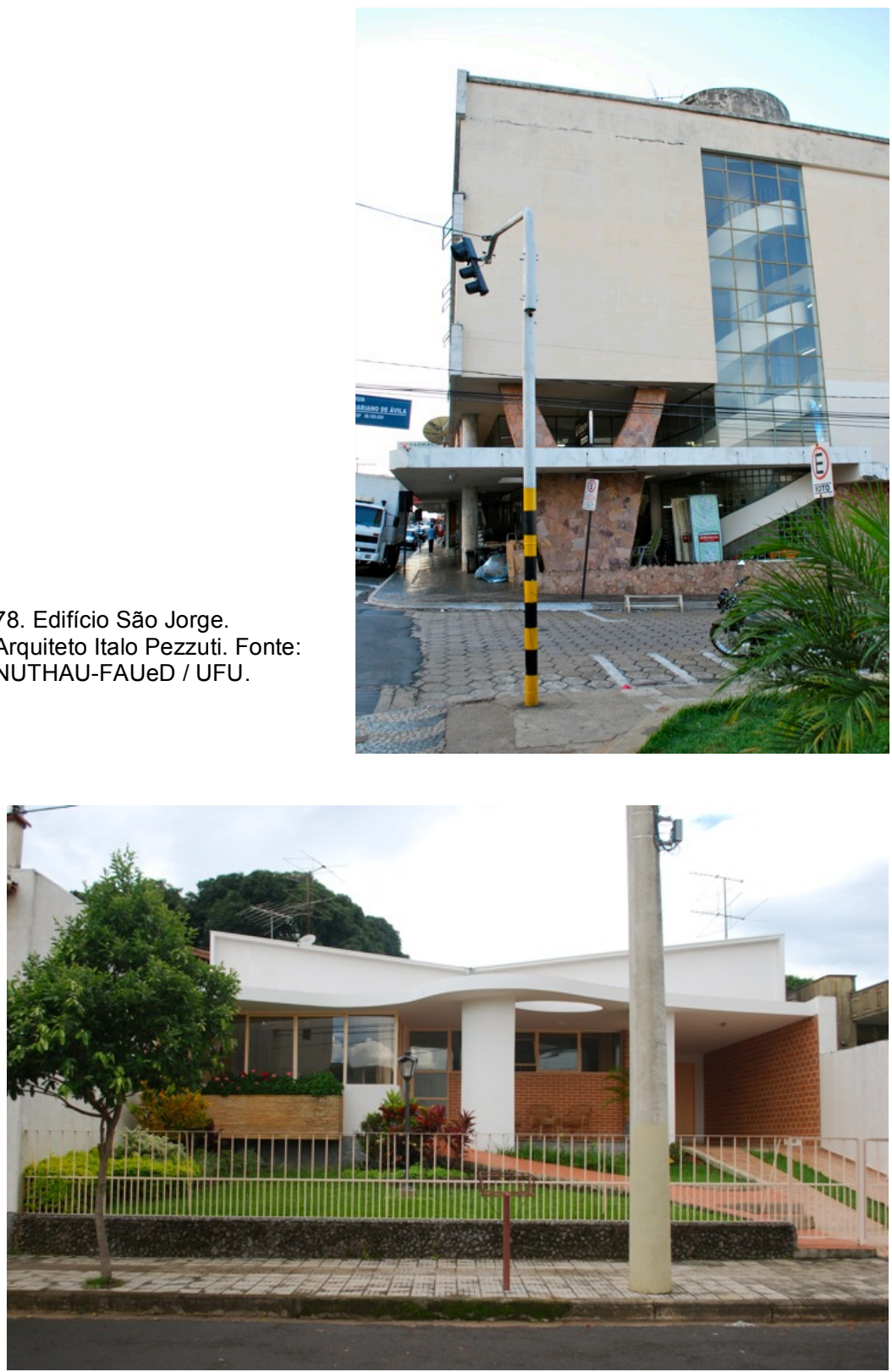

79. Res. Regina P. B Resende. Arquiteto Italo Pezzuti. Fonte: NUTHAUFAUeD / UFU.

Em 1954, a residência de Theofredo Pinto Silva, projetada por Ítalo

Pezzuti, foi publicada na Revista Arquitetura e Engenharia, provavelmente uma das primeiras residências modernas de Araxá. A casa teve sua planta solucionada de forma funcional, seu acesso se dá por meio à uma varanda ajardinada, onde a laje plana impermeabilizada avança, prolongando-se até a fachada lateral, onde se transforma em um abrigo para garagem. Para algumas soluções, Pezzuti tira proveito do potencial dos tijolos de concreto furados da 
própria obra, elabora um painel vazado na fachada principal, protegendo a área do sol da tarde e auxiliando na privacidade do interior da casa, uma vez que as janelas de vidro são quase inteiriças, com peitoril muito baixo, prolongando-se até o teto. No interior, entre a área social e a área íntima dos quartos, Pezzuti faz a transposição através de uma sala para almoço, em cujas adjacências dispõe uma sala de estudos e a cozinha, por onde se acessa as dependências de serviços, aos fundos da casa. A solução utilizada na planta desenha uma volumetria pura, sem muitos revestimentos, permeada pela vasta área de vegetação circundante. A publicação na revista Arquitetura e Engenharia sublinha a escolha do arquiteto por materiais simples, "devido as dificuldades que oferecem as construções do interior"48.

Além de Pezzuti, outros nomes apareciam na revista Arquitetura e Engenharia. No início dos anos de 1950, na página de anunciados, nomes como o de Raphael Hardy Filho, Sylvio Vasconcelos, Shakespeare Gomes, Jefferson J. Lodi, Ulpiano Muniz, todos arquitetos que deixaram suas arquiteturas modernas no Triângulo Mineiro. Eram publicados projetos dos arquitetos mineiros, de São Paulo, Rio de Janeiro e de algumas cidades do nordeste. Os pontos de venda, divulgados em página específica da revista, incluíam além de Belo Horizonte, as cidades de Juiz de Fora, Rio de Janeiro, São Paulo, Curitiba, Recife, Salvador, Belém do Pará, etc. Em 1959, na edição de número 52, Jarbas Karman publicou um texto intitulado "arquitetura hospitalar", tema que se especializou em sua carreira. Seu Hospital São Domingos, em Uberaba, é de 1958. Em 1962, na edição de número 64, foi publicado o projeto de Galileu Reis para o Caiçaras Country Clube, em Patos de Minas.

\footnotetext{
${ }^{48}$ ARQUITETURA E ENGENHARIA. Belo Horizonte, n. 32, jul/set. 1954.
} 


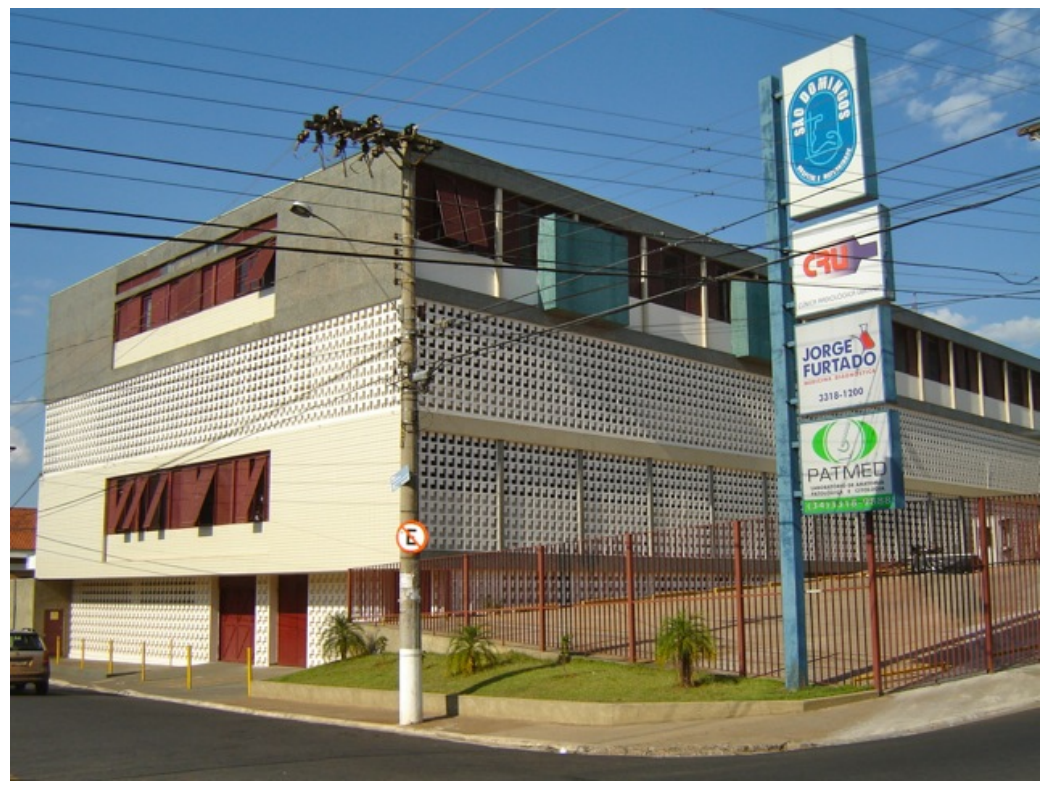

80. Hospital São Domingos. Arquiteto Jarbas Karman. Fonte: NUTHAU-FAUeD / UFU.

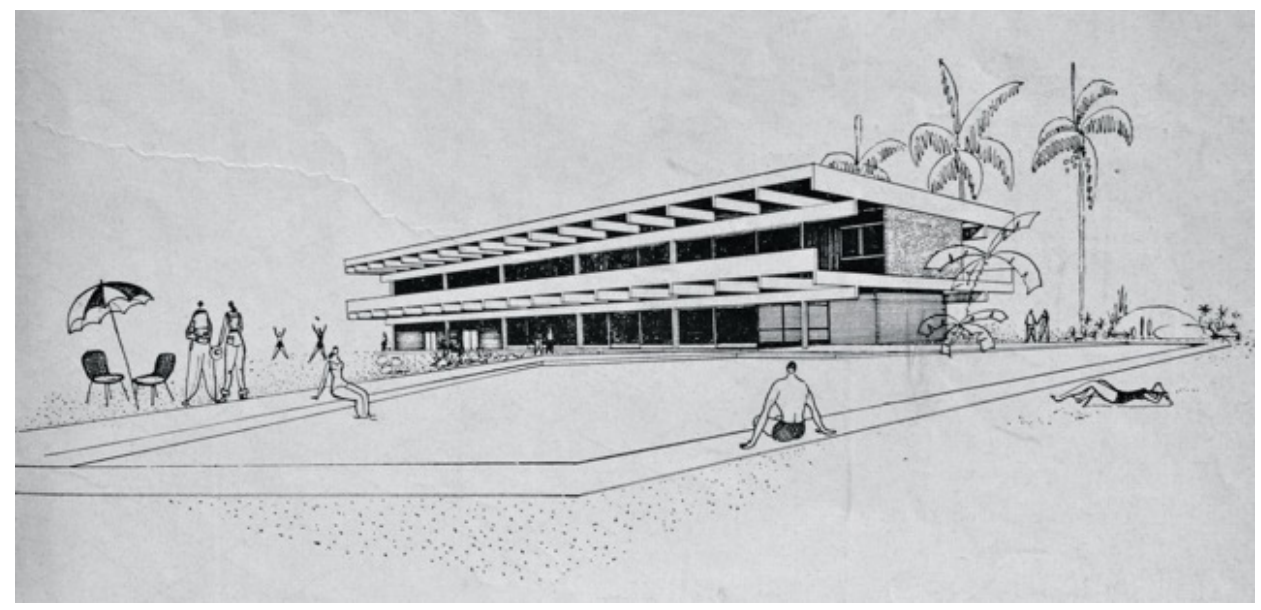

81. Caiçaras Country Clube. Perspectiva. Arquiteto Galileu Reis. Fonte: Arquitetura e Engenharia, n. 64, 1962.

Shakespeare Gomes, contemporâneo à Coury e Hardy na Escola de Arquitetura, fez parte, junto a este último, do conselho diretor da revista Arquitetura e Engenharia, onde foi publicado seu projeto para o edifício da EABH. Em comum, esses dois arquitetos também têm a passagem, no início de suas carreiras, pelo escritório de Signorelli, e a atuação como docentes na escola. Na década de 1950, Shakespeare Gomes projeta uma residência em Araguari, localizada em frente à Praça Getúlio Vargas, principal da cidade. A residência, em dois pavimentos, possui um afastamento frontal, onde o 
arquiteto desenha um jardim e coloca grandes panos de vidro na fachada correspondente à sala de estar, onde Gomes soluciona a incidência solar com um brise móvel. Para conseguir áreas de sombra e abrigos no térreo, o arquiteto também utiliza do balanço da laje do pavimento superior. Toda volumetria é um jogo de cheios e vazios, evidenciando as formas planas, como a protuberância da laje superior e da platibanda, conseguindo, ao final, um volume mais leve.

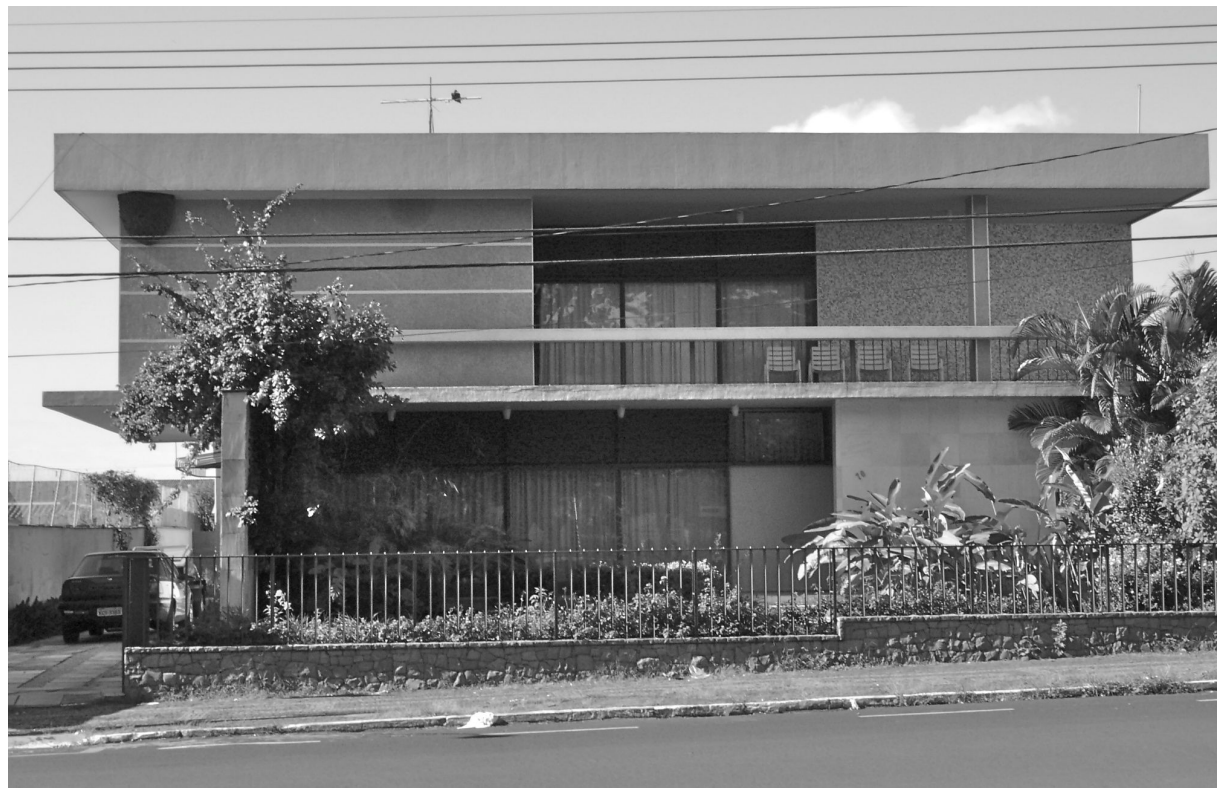

82. Residência de Shakespeare Gomes, em Araguari. Fonte: NUTHAU-FAUeD / UFU.

83. Residência de Shakespeare Gomes, em Araguari. Fonte: NUTHAU-FAUeD / UFU.

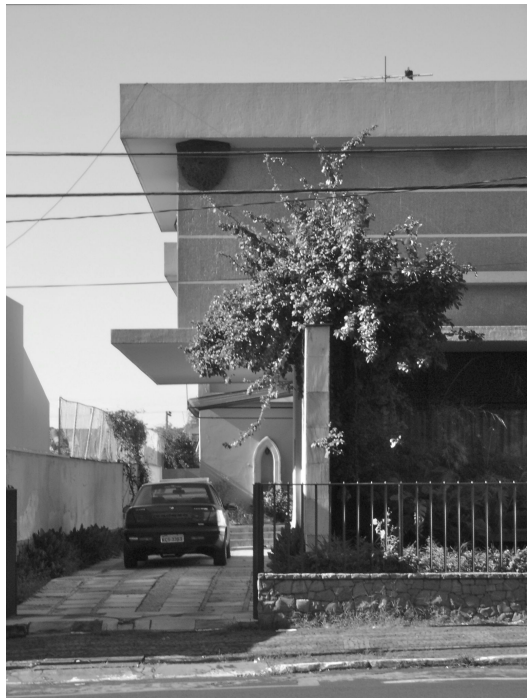


Também em Araguari, um projeto de grande escala que se destaca é o Conjunto Residencial - IAPB (Instituto de Aposentadorias e Pensões dos Bancários) para os funcionários dos bancos do município. Sob coordenação da Prof. Dra. Maria Beatriz Camargo Cappello, inserido em outros projetos de pesquisa do NUTHAU-FAUeD/UFU, foi descoberto que o conjunto foi projetado em 1957 por Carlos Henrique Oliveira Porto, que também foi autor do projeto da Escola Industrial do Rio de Janeiro, de 1942, que aparece no livro Brazil Builds, publicado pelo MoMA de Nova York em $1943 .{ }^{49}$

Nesse momento de introduções da arquitetura moderna no Triângulo Mineiro e Alto Paranaíba, que tem a década de 1950 como um cenário de encadeamento, outras obras que foram documentadas também merecem destaque. Em 1956, o arquiteto Sylvio Vasconcelos, aluno e depois professor da EABH, projeta a Residência Bolivar Carneiro, em Uberlândia. Também, nessa cidade, o Uberlândia Clube, projetado pelo engenheiro Almor Cunha, em 1956, estabelece uma relação inovadora com o pedestre, conseguida pela recuo da fachada em pilotis, onde se formava uma galeria.

84. Conjunto Residencial IAPB, em Araguari. Fonte: Arquivo Público Municipal de Araguari. NUTHAU-FAUeD / UFU.

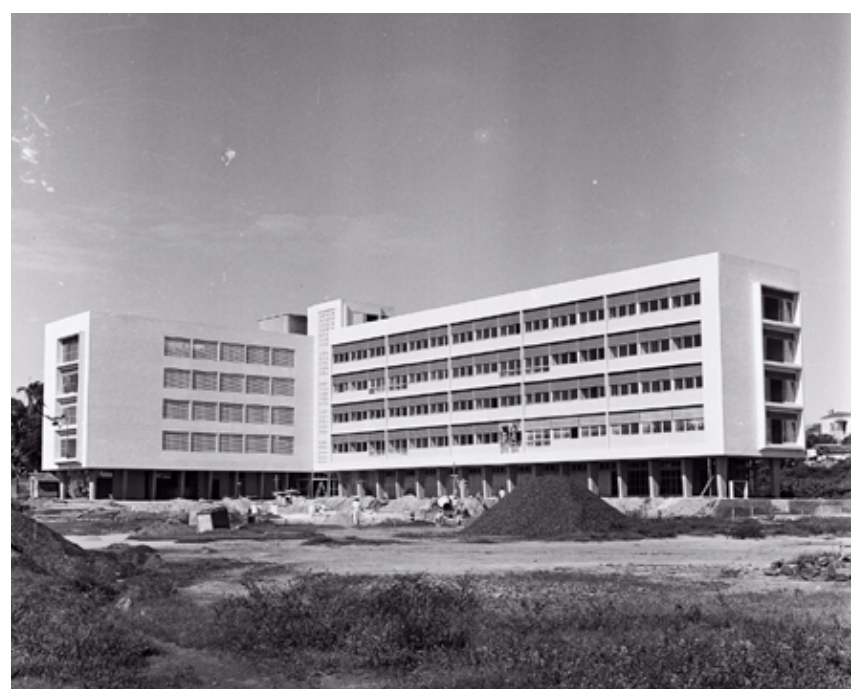

${ }^{49}$ A Prof. Dra. Maria Beatriz Camargo Cappello, tem coordenado projetos de pesquisa que envolvem estudos acerca da arquitetura moderna brasileira e sua recepção nas revistas de arquitetura: Arquitetura moderna no Brasil e sua recepção nas revistas européias e brasileiras (1945-1960); Arquitetura moderna brasileira e sua recepção nas revistas de arquitetura norteamericanas e latino-americanas (1930-1960); Recepção e Difusão da arquitetura moderna brasileira nas revistas francesas, inglesas e italianas. 
85. Conjunto Residencial IAPB, em Araguari. Fonte: Arquivo Público Municipal de Araguari. NUTHAUFAUeD / UFU.

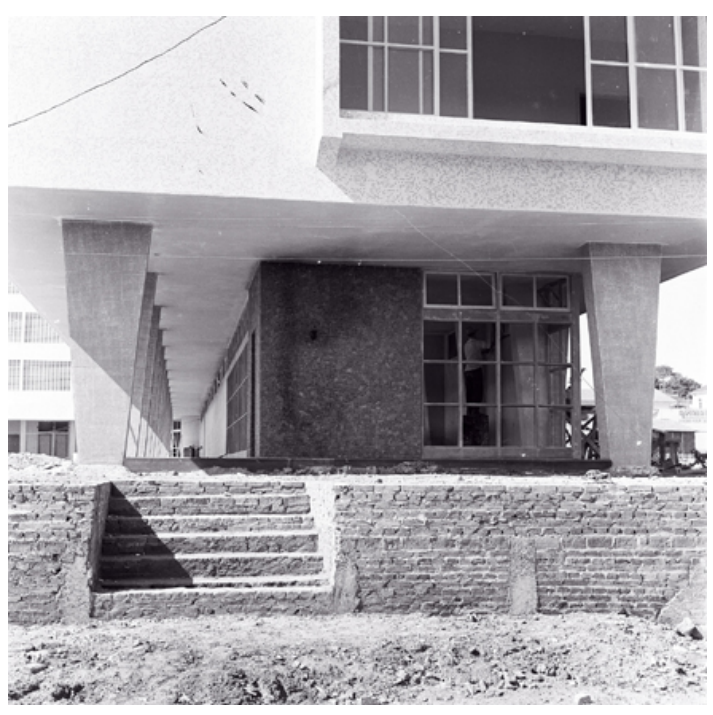

Mais do que as características peculiares da obra de João Jorge Coury, a importância deste arquiteto para a produção da arquitetura moderna do Triângulo Mineiro e Alto Paranaíba está no fato dele ter sido o primeiro profissional a se fixar na região produzindo uma arquitetura moderna, desencadeando um processo onde alguns de seus discípulos irão tomar o mesmo caminho. Como exemplos, temos Helvio Felice e Natalino Thomaz, formados respectivamente na EABH em 1958 e 1960, e Paulo de Freitas, formado em 1955 na Escola de Arquitetura da Universidade Mackenzie. Estes três arquitetos naturais de Uberlândia, voltam a cidade para atuar profissionalmente após suas graduações, como relata Laurentiz (1993).

Também, no decorrer na década de 1960, o Triângulo Mineiro vai sofrer um forte processo de fluxo migratório, culminando em uma década de 1970 com o recebimento de um impactante contingente populacional que se dirigia ao Centro-Oeste e Norte do país. A incidência desse fluxo migratório se insere na difusão da arquitetura moderna da região, uma vez que este processo irá trazer outros diversos arquitetos para trabalhar na região. Há de se considerar, que também há, nesse fluxo migratório, um outro fluxo, que são de ideias, e que 
sendo trazidas e levadas por esses profissionais, ajudaram a formar uma nova cultura arquitetônica para a região.

\section{ENGENHEIRO-ARQUITETO}

Arquiteto esforçado e trabalhador, com prática em construções, desejando estabelecer-se no Triângulo Mineiro, procura firma idônea ou colega já estabelecido que se interessem em seus serviços.

mente, a

Obséquio dirigir-se, por carta ou pessoal-

\section{Arquiteto - Apartamento 202.}

Grande Hotel Colombo - Uberlândia

86. Recorte do Jornal Correio de Uberlândia, no ano de 1960 .. Fonte: CORREIO, Jornal. Uberlândia, ago. 1960. APU.CPJA

Como produção periférica do país, a década de 1950 é o período de início de uma historiografia local acerca da produção moderna do Triângulo Mineiro e Alto Paranaíba, diferentemente da historiografia da produção moderna das capitais Rio de Janeiro, São Paulo e Belo Horizonte. Nessas capitais, a década de 1950 já se apresentava como um período de crítica de uma arquitetura que tinha cerca de duas décadas de produção, no Triângulo Mineiro, era o contexto da inserção do moderno na construção civil, e que teria o estopim após 1960, com a inauguração de Brasília. Em 1960, anunciava em propaganda do escritório de Coury, em um jornal de Uberlândia: "estamos organizados para administrar inclusive obras de Brasília."50

A década de 1950, como momento das primeiras e substanciais manifestações da arquitetura moderna na região, demonstrou ter muito da consequência de um ideário progressista que vinha sendo formado. Vimos que este imaginário auxiliava a introdução da nova arquitetura na medida em que a população local a identificava como símbolo de um progresso almejado, o qual,

${ }^{50}$ CORREIO DE UBERLÂNDIA, Uberlândia, 14 Abr. 1960. 
a construção de um "valor moderno" já havia passado pelo eclético, o art decó e agora tinha a arquitetura moderna como protagonista.

Ainda, podemos dizer que esse primeiro momento demonstrou também uma certa unidade de concepções projetuais, onde podemos citar um diálogo com a arquitetura da escola carioca. No próximo capítulo, iremos abordar os contornos da produção moderna no Triângulo Mineiro e Alto Paranaíba no pós60 , o qual vai nos mostrar um quadro de obras modernas que se define por meio de projetos com concepções diversificadas e plurais. 


\section{Capítulo 3}

ARQUITETURA MODERNA NO TRIÂNGULO MINEIRO E ALTO PARANAÍBA PÓS-60 

Nos capítulos anteriores vimos que o histórico de envolvimento da região nas estratégias geopolíticas de interiorização do país fez parte do desenvolvimento econômico do Triângulo Mineiro e Alto Paranaíba. Vimos também que esse envolvimento, onde as relações com São Paulo se estreitavam, incidiam na inserção da arquitetura moderna na região à medida que a população local ia relacionando-a com uma ideia de progresso ou "moderno". No capítulo dois vimos que a produção moderna regional avançava durante toda a década de 1950.

Vimos no capítulo um que, até meados da década de 1950, o Triângulo Mineiro tirara proveito do seu posicionamento estratégico, favorecendo-se dos planos de desenvolvimento do Estado e que, nessa conjuntura, a construção de Brasília apareceria como resultado das dinâmicas econômicas que envolveram todo o histórico do desenvolvimento da região. Com a construção da nova capital, o Triângulo Mineiro passava da qualidade enquanto rota para o Brasil Central para se tornar a rota de ligação entre São Paulo e a sede do Governo Federal.

Dessa forma, o Triângulo Mineiro ia se consolidando enquanto área de abastecimento da nova capital, adequando-se às novas atribuições requeridas pelo deslocamento da sede do Governo Federal. A região favorecia-se da expansão das malhas de rodagem que recortavam o país, e das novas dinâmicas construtivas que brotaram a partir da necessidade de materiais de construção para Brasília. Lembramos, à exemplo do que foi dito no capítulo um, que o ao longo do seu histórico de desenvolvimento, o Triângulo Mineiro se beneficiara com o excedente deixado pelo escoamento de produtos para o Brasil Central e que, no momento da construção de Brasília, grande excedente de materiais de construção foi aproveitado pelas cidades da região.

Essas novas dinâmicas construtivas incidem diretamente na inserção e difusão da arquitetura moderna no Triângulo Mineiro e Alto Paranaíba. No 
entanto, não somente pelo avanço das possibilidades construtivas, Brasília incidia na produção da arquitetura moderna regional. A produção de arquitetura moderna no Triângulo Mineiro foi, em outros sentidos, em termos de conhecimento, divulgação e apropriação de uma nova linguagem, estimulada pela construção de Brasília. Há de se considerar, por exemplo, a participação de Brasília no processo de democratização da arquitetura moderna brasileira em todo Brasil, visto que, apesar do grande numero de revistas especializadas durante a década de 1950, mantinha sua popularidade e suas discussões entre as elites e os profissionais especializados.

A década de 1960 - assim como a década 1970 - abarca o período de estabelecimento dos princípios modernos na construção civil da mesorregião do Triângulo Mineiro e Alto Paranaíba. Esse aumento da produção moderna a partir dos anos de 1960, e que acompanha os anos após a inauguração de Brasília, revela o aumento de arquitetos residentes na região, o processo de apropriação dessa linguagem por esses profissionais, mas também, o processo crescente de recepção da nova arquitetura pela população regional.

Nesse momento, ainda são maioria os edifícios modernos de tipologia residencial, seguida por edifícios de comércio, lazer e serviços. Uma mudança significativa nesse momento é causada pelo incentivo aos arranha-céus, geralmente edifícios habitacionais ou mistos, os quais iam mudando aos poucos a paisagem urbana da região central das cidades. Essa produção revelou, sobretudo, que pouco houve de hegemônico na arquitetura moderna triangulina. Esse conjunto moderno demonstrou-se composto por uma mescla de opções formais, soluções técnicas e estéticas, projetados por arquitetos residentes, imigrantes ou das grandes capitais. 


\section{A Estação Ferroviária de Oswaldo Arthur Bratke em Uberlândia: arquitetura ligada à cultura de transportes}

Se pensarmos em uma cultura de desenvolvimento do Triângulo Mineiro e Alto Paranaíba, isto é, em um conjunto de operações, estratégias e interlocuções responsáveis pelo avanço econômico da região, esta cultura estaria diretamente associada à característica peculiar da mesorregião enquanto rota de passagem, onde a ampliação de seu sistema de transportes foi essencial.

No início do século XX, o quadro populacional do Triângulo Mineiro e Alto Paranaíba já demonstrava os efeitos sobre a dinâmica econômica das cidades pelo desenvolvimento dos sistemas de escoamento de produtos, a começar pela instalação das estradas de ferro. Não é coincidência que as principais e mais populosas cidades, hoje, na região, são as escolhidas pela Companhia de Estradas de Ferro Mogiana para a rota das linhas férreas que cruzariam o oeste de Minas, entre Goiás e São Paulo. As cidades do Triângulo cruzadas pela ferrovia eram Uberaba, com estação inaugurada em 1889, Uberabinha (atual Uberlândia), inaugurada em 1895 e Araguari, em $1896 .^{1}$

Em meados do século XX, o Triângulo Mineiro já se inseria na dinâmica do mercado nacional, devendo muito à fundamental infra-estrutura das redes de transportes, onde as estradas de rodagem viriam complementar os fluxos comerciais já efetuados pelas estradas de ferro. Quando chegou a Cia Mogiana na região, esteve assegurada a acessibilidade dos produtos agrícolas e agropecuários do Brasil Central à capital paulista, fazendo com que o Triângulo se inserisse em um dos mais importantes circuitos mercantis do país. A implantação da Companhia de Estradas de Ferro Mogiana, em fins do século XIX, é o mais importante agente na intensificação da característica do território

\footnotetext{
${ }^{1}$ Ver mais em Lourenço (2007), onde o autor discorre acerca da formação do trajeto da Mogiana no Triângulo Mineiro.
} 
como ligação entre importantes núcleos comerciais e de produção do sudeste e do interior centro-oeste do país.

A cidade de Uberlândia, hoje, maior da região, teve seu crescimento impulsionado pelo desenvolvimento de sua rede de transportes. Com a expansão do sistema rodoviário, conseguido pela estratégica construção da Companhia Mineira de Auto Viação, já no início do século XX, essa cidade assumia o papel de pólo regional. Os embates entre as cidades do Triângulo Mineiro pela hegemonia do sistema de escoamento de produtos demonstra a importância do sistema de transportes na transformação econômica e urbana dessas cidades.

As estações do arquiteto Oswaldo Arthur Bratke para a Companhia Mogiana de Estradas de Ferro, na década de 1960, vieram em um momento em que a empresa buscava alternativas ao passo da decadência que vinha sofrendo, com pouco mais de cinquenta anos do negócio. O sucateamento da empresa, o não cumprimento de contratos, as deficiências no material rodante desconfortável e mal conservado, aliado ao privilegio nos investimentos para estradas de rodagem, fez com que as estradas de ferro fossem perdendo espaço na preferência popular e também nas políticas de transportes do país. A decadência no setor ferroviário não foi exclusiva da Mogiana e fez com que várias empresas fossem assumidas pelo Estado, entre outras que decretaram falência. ${ }^{2}$ (MESQUITA E SILVA, 2006)

Já na década de 1940, a conjuntura decadente dava as caras na aceitação popular. Os investimentos efetuados pela Mogiana pareciam não corresponder às expectativas da população local. A inauguração da nova estação, na então periferia da cidade de Uberlândia, foi alvo de críticas pela elite local, onde o repúdio lançava julgamentos inclusive à arquitetura art déco da nova estação, além da sua suposta incapacidade ao abrigo de passageiros. Fato que nos permite novamente supor que pairava na cidade, no início dos anos de

\footnotetext{
${ }^{2}$ No caso da Mogiana, a empresa foi assumida pela Secretaria da Fazenda do Estado de São Paulo. Ver mais em Mesquita e Silva (2006).
} 
1940, um imaginário progressista, que tinha seus contornos nas novas construções e suas representações. ${ }^{3}$

A arquitetura de grandes obras, ao longo do tempo, esteve vinculada à estilos que visavam corresponder a grandiosidade do edifício, onde os neoclássicos e ecléticos se destacavam. O repúdio à um "estilo modernizante", como o art déco, demonstra os meandros dos variados tipos de um ideal de "modernidade", que têm suas especificidades no imaginário popular, na atuação dos governantes e na arquitetura moderna brasileira erudita.

Tivemos a impressão de que fosse aparecer um prédio, pelo menos apresentável e no entanto, lá está um armazém bem pintado e que nós chamamos pomposamente de 'nova Estação da Companhia Mogiana'. [...] a nova estação não corresponde ao desenvolvimento da cidade e não corresponde também à idade dessa companhia, que serve a esta zona há mais de 50 anos. A Companhia já hoje não serve mais aos nossos interesses e ao contrário é um verdadeiro entrave ao nosso progresso [...]. (CORREIO DE UBERLÂNDIA. 05.08.1941, p.3. apud MESQUITA; SILVA, 2006)

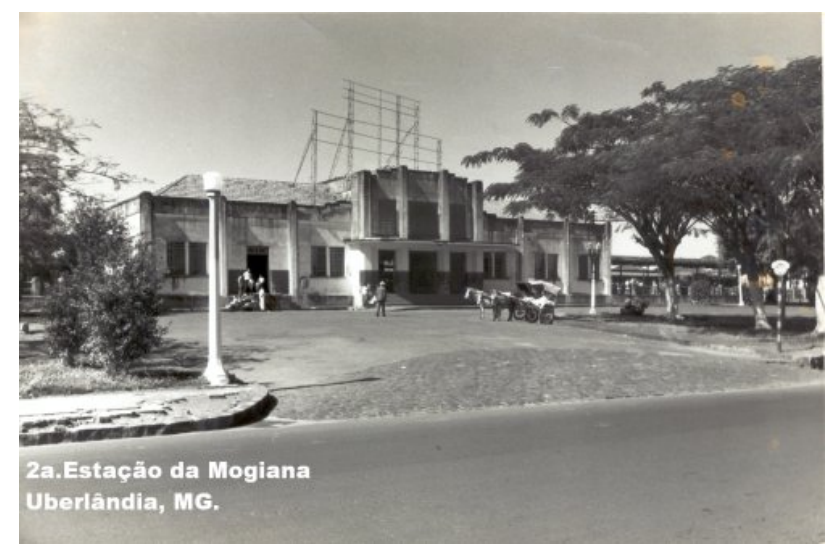

89. Segunda Estação Ferroviária de Uberlândia, inaugurada em 1946. Fonte: www.estacoesferroviarias.com.br

\footnotetext{
${ }^{3}$ Ver capítulo dois: um imaginário moderno na dinâmica construtiva do Triângulo.
} 
Até a década de 1970, a Mogiana apresentou esforços em melhoria tecnológica a fim de contornar as dificuldades. Na década de 1960, a empresa contratou o arquiteto Oswaldo Arthur Bratke para a elaboração das novas estações de Uberlândia - a qual daremos destaque nessa seção do trabalho - de Uberaba e de Ribeirão Preto, as quais apresentam projetos bem semelhantes. A escolha por uma arquiteto moderno e com certo renome nos permite conjecturar que esta era uma escolha que partia de um conjunto de estratégias, as quais objetivavam a contenção da decadência da empresa. Junto aos serviços de luxo, como os novos trens para Brasília, a arquitetura moderna das novas estações deveriam corresponder à uma imagem popular de progresso ou "modernidade". Lembramos que a divulgação da arquitetura moderna através da construção de Brasília é um fato substancial para a aceitação dessa nova linguagem arquitetônica e sua assimilação pela população.

90. CORREIO DE UBERLÂNDIA, Uberlândia, 13 Fev. 1970. Fonte: Arquivo Público Municipal de Uberlândia.

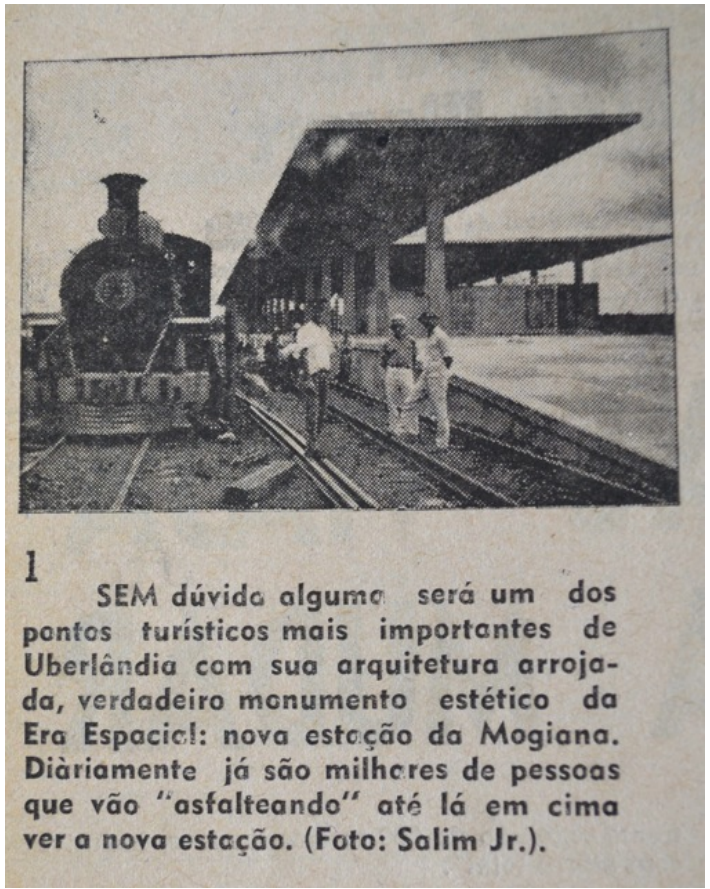


À época da inauguração, em 1970, a moderna estação de Uberlândia parece ter rendido o impacto esperado. As páginas do Jornal Correio exibiram a nova obra como "monumento de arquitetura futurista" ${ }^{\text {, }}$ ou em outra ocasião, uma "arquitetura arrojada, verdadeiro monumento estético da Era Espacial" ${ }^{5}$. Descreveram a ocasião da inauguração como abertura de um novo ponto turístico para a cidade. Contrariando a expectativa, a Companhia não conseguiu se reerguer, sendo incorporada à FEPASA (Ferrovias Paulistas S.A), cerca de um ano depois da inauguração da nova estação de Uberlândia. O espaço primordial das estradas de ferro na região já haviam sido tomadas pelas estadas de rodagem.

$\mathrm{Na}$ pesquisa feita pelo NUTHAU-UFU, verificou-se que a Estação Ferroviária de Uberlândia foi a terceira construída pela Mogiana, a qual substituiria a segunda, situada ao final da Avenida Afonso Pena e atual Praça Sérgio Pacheco, que até a década de 1930, definia o limite norte da malha urbana da cidade. Objetivava-se com a nova estação, a expansão desta área, que seria induzida pelo fluxo de pessoas, mercadorias e serviços atraídos pela nova implantação da estação. Distante do centro adensado de Uberlândia, a nova Estação da Mogiana viria direcionar e determinar um novo traçado urbano.

A localização da nova estação ferroviária em Uberlândia foi definida conjuntamente pela Companhia Mogiana, o governo municipal e o arquiteto que prepuseram sua implantação em uma área periférica à malha urbana, no Bairro Custódio Pereira, localizado no setor Leste, próxima à Rodovia BR 050 - que liga São Paulo à Brasília - e ao aeroporto da cidade. Esta decisão contemplava o projeto de expansão do espaço urbano cogitado desde o início da década de 1950. A remoção da antiga Estação Ferroviária permitiu o prolongamento das avenidas centrais (Floriano Peixoto, Afonso Pena e Cesário Alvim), integrando a já área urbanizada depois dos

\footnotetext{
${ }^{4}$ Jornal Correio de Uberlândia. 09.04.1970.

${ }^{5}$ Jornal Correio de Uberlândia. 13.02.1970.
} 
trilhos à região mais antiga da cidade; a remoção dos trilhos e a pavimentação de seu leito deram origem às avenidas João Naves de Ávila e Monsenhor Eduardo, que se converteram em importantes vias arteriais da cidade; a nova estação tornou-se importante elemento de orientação da expansão na direção Leste. (VALE, 2010)

O projeto de Bratke pressupunha que estações ferroviárias eram importantes referências urbanas, uma vez que induziam o crescimento e desenvolvimento da área de entorno. Desse modo, a ideia do arquiteto foi elaborar um edifício que extrapolasse o programa exclusivo da estação, adicionando também um programa que desse suporte à locação de outros serviços e equipamentos, que não somente aqueles destinados ao transporte e apoio de passageiros, como comércios que poderiam ser terceirizados pela Mogiana.

O projeto da Estação Ferroviária de Uberlândia foi dividido em dois blocos, sendo o primeiro destinado à estrutura ferroviária, como o pátio de manobras e dependências específicas da estação, e o segundo, o programa que incluía a complementação das utilidades de apoio aos passageiros, como as áreas comerciais e de serviços mais voltados para o bairro. Desse modo, a implantação da estação seria feita em três etapas: a primeira, correspondente à infra-estrutura ferroviária e dependências da estação; a segunda envolvendo a complementação das atividades de apoio aos passageiros, e a terceira que correspondia ao setor commercial e de serviços voltados ao bairro. Porém, na Estação de Uberlândia, (assim como na Estação de Ribeirão Preto) apenas a primeira etapa do projeto foi executada. (RIBEIRO; VALE, 2010)

A Estação Ferroviária de Uberlândia se resume em uma grande cobertura em concreto aparente, com estrutura independente, suspensa e separada da estrutura dos cômodos de comércio e serviços distribuídos ao nível do usuário, em uma planta de partido horizontal, cuja estrutura da cobertura 
monumental apresenta-se como um referencial urbano.

De modo geral, pode-se dizer que o projeto é definido por uma grande cobertura que se desenha através da repetição de um único módulo: uma forma parabolóide hiperbólica com estrutura em concreto armado apoiado centralmente por um pilar. Especificamente, o módulo é uma estrutura autônoma em concreto pré-moldado e chapas corrugadas de cimento amianto, pré-moldadas e fixadas através de parafusos, cuja altura do pé-direito é de 3,20 metros. A água pluvial é captada pela forma hiperbólica, que desce por um condutor localizado dentro do pilar central do módulo, desembocando em uma canaleta aberta, próxima aos trilhos.

91. Forma parabolóide hiperbólica. Fonte: CONSIGLIERI, 1994 apud RIBEIRO; VALE, 2010.

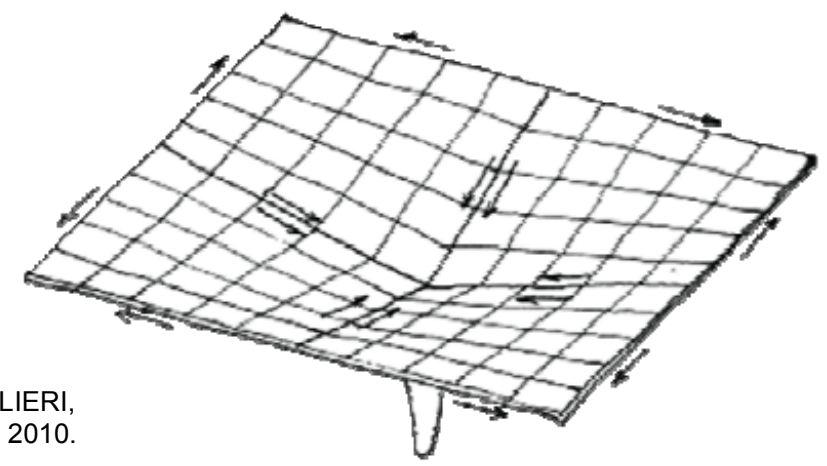

Essa solução projetual, da configuração espacial através de um único módulo, permitia que o edifício pudesse ser expandido em necessidades futuras, sem que a reforma prejudicasse o funcionamento dos setores já implantados. Somado à isso, a independência estrutural da cobertura permitia ainda uma configuração em planta livre, onde os cômodos sobre essa, como caixas soltas, poderiam ser dispostos com maior liberdade. A separação entre cobertura e cômodos, também aliava-se à estratégia projetual com preocupações com o conforto térmico, cuja solução adotada possibilitava o fluxo livre de ar por todo prédio. 


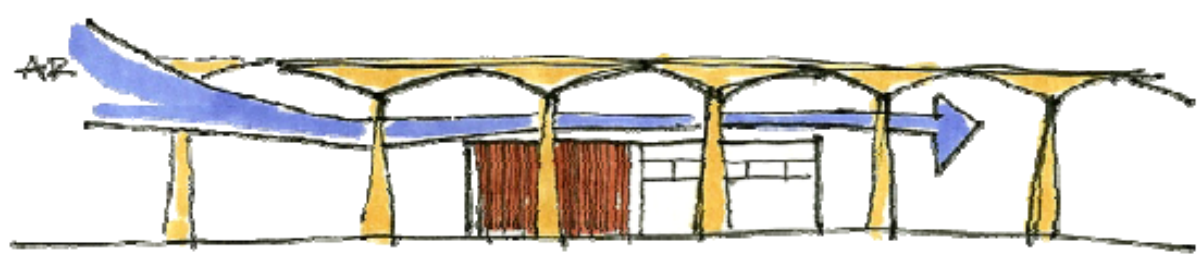

92. Esquematização da circulação de ar. Estação Ferroviária de Uberlândia. Fonte: RIBEIRO; VALE, 2010

Bratke consegue que o desenho que assimilamos ao ver o prédio parta do reconhecimento de sua cobertura, que está separada dos volumes que formam os cômodos para as atividades da ferroviária. Essa percepção, da distinção entre cobertura e cômodos, no entanto, ainda consegue ser assimilada pelo usuário no reconhecimento do prédio como um todo, o que se deve muito à continuidade da cobertura, de partido horizontal, e pela área de implantação, pouco adensada.

Os cômodos distribuídos sobre a cobertura têm vedação em tijolo maciço de cerâmica. Em alguns casos, são revestidos por chapas corrugadas de cimento amianto, parafusadas ou engastadas na alvenaria. Em algumas paredes, como na face externa das esquadrias, foram colocados painéis vazados de concreto. Percebe-se na estação, a criatividade técnica de Bratke, que também desenhou todas as esquadrias do projeto, e cuja inventividade objetivava claramente à otimização do funcionamento do edifício. ${ }^{6}$

O seu desenho para a janela basculante possibilitava que ela se abrisse por inteiro, permitindo, por exemplo, que ela pudesse ser limpa sem o empecilho do painel vazado em sua face externa. Seu mecanismo consistia em pivotar a peça superior do caixilho de vidro e erguer a peça inferior de maior comprimento, presa à superior. Outra solução peculiar projetada por Bratke foi a chamada

\footnotetext{
${ }^{6}$ As descrições do projeto partiram da ficha de inventário e de todo material coletado sobre o edifício no NUTHAU-FAUED / UFU.
} 
"porta com eixo de gravidade", colocada nos sanitários, cujo mecanismo presente no pivô da porta fazia com que a mesma ficasse sempre fechada. (RIBEIRO; VALE, 2010)

As soluções de Bratke demonstram a preocupação do arquiteto em projetar uma arquitetura funcional, preocupada com o todo, e nos seus pormenores. Sua arquitetura adequa o programa de forma racional e clara, onde cada decisão consegue ser lida facilmente pelo usuário. Na Estação Ferroviária de Uberlândia, a forma não se sustenta por si só, e não há decisões puramente estéticas. Estética e função estão em acordo, demonstrando seu comprometimento com uma arquitetura moderna de partido racionalizante, empenhada em perseguir as soluções possibilitadas pelo avanço industrial.
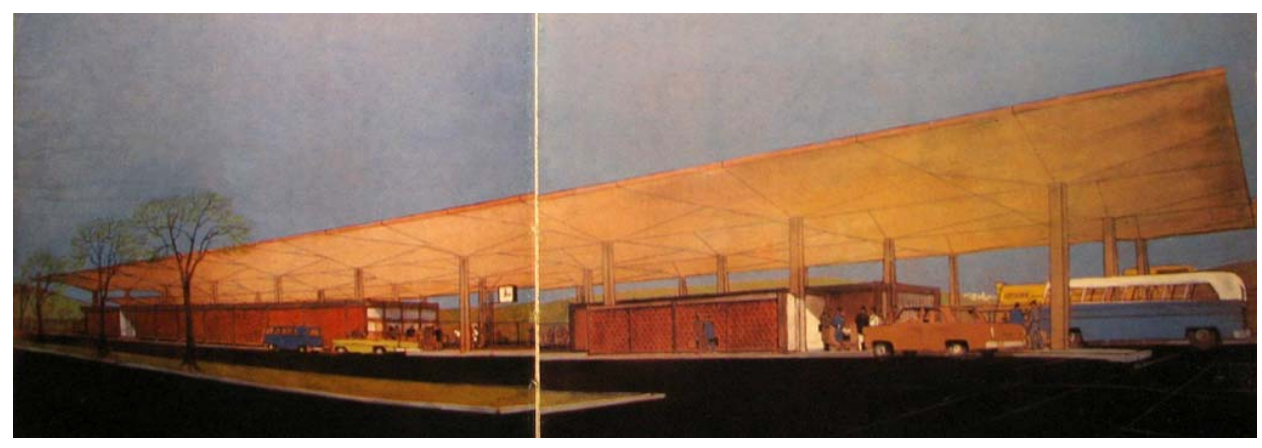

93. Estação Ferroviária de Uberlândia. Perspectiva. Fonte: SEGAWA; DOURADO, 1997.

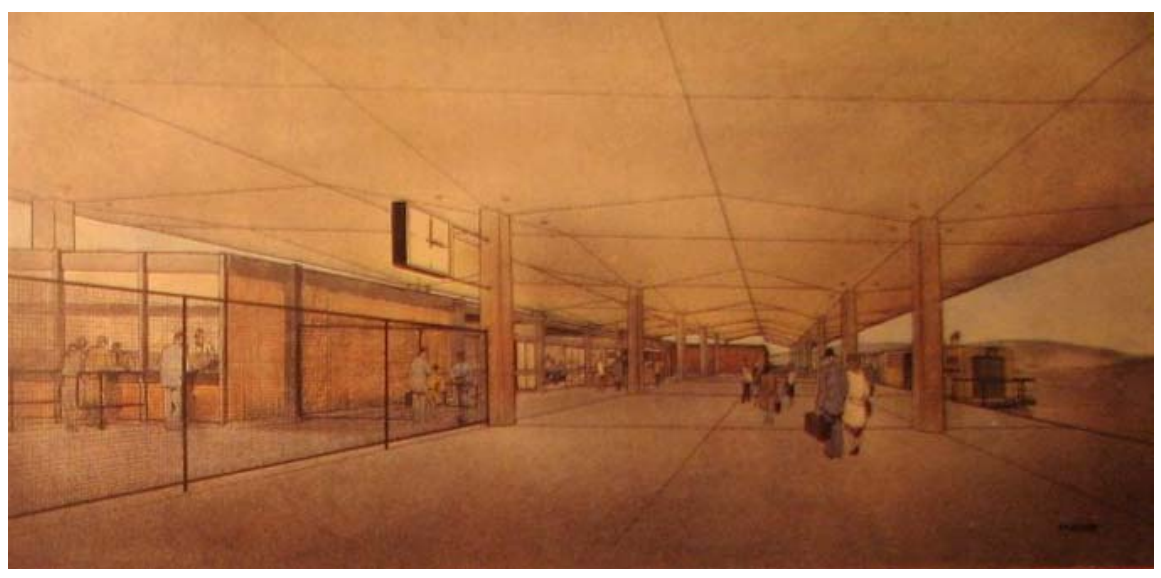

94. Estação Ferroviária de Uberlândia. Perspectiva do interior. Fonte: SEGAWA; DOURADO, 1997. 


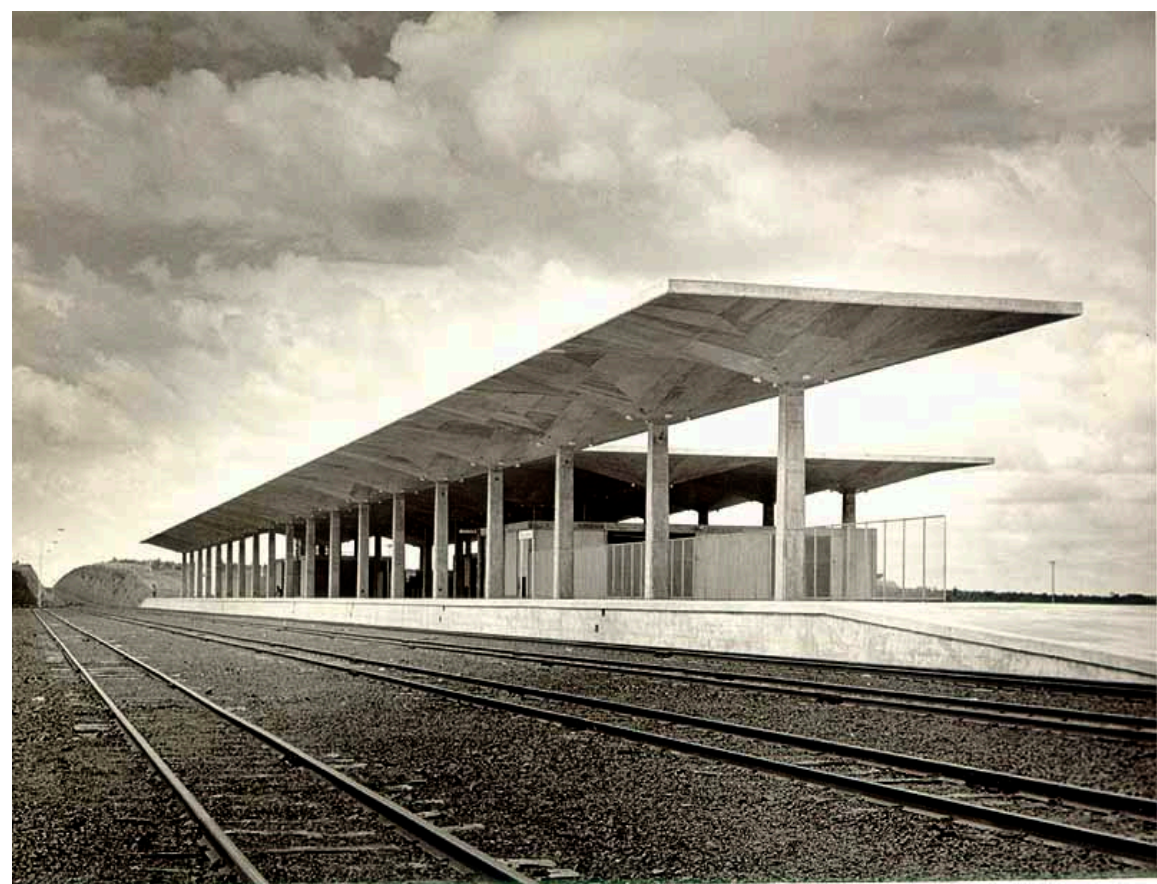

95. Estação Ferroviária de Uberlândia. Fonte: www.cmef.com.br

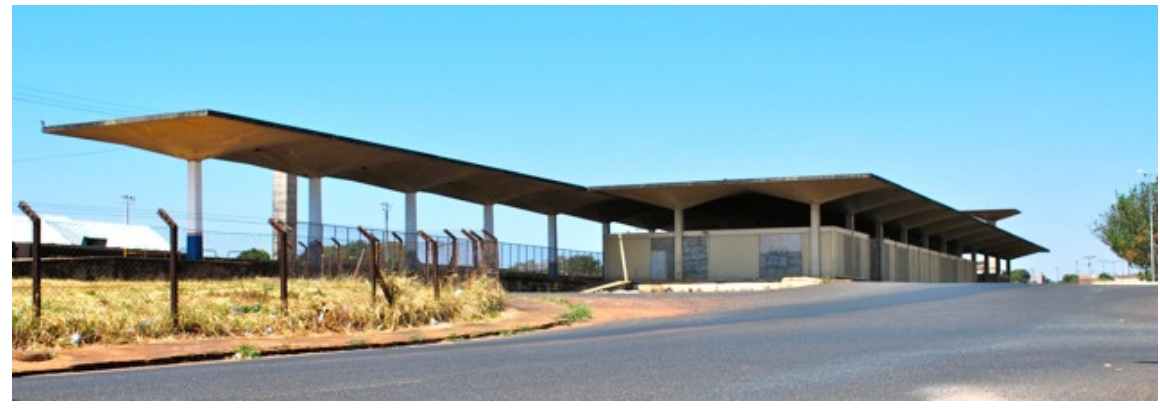

96. Estação Ferroviária de Uberlândia. Fonte: NUTHAU-FAUeD / UFU.

Na década de 1970, a construção do novo Terminal Rodoviário de Uberlândia, somava-se a infra-estrutura da ferrovia e do aeroporto da cidade. $\mathrm{O}$ Terminal Rodoviário Presidente Castelo Branco, inaugurado em 1976, projeto dos arquitetos belo-horizontinos Fernando Graça, Flávio Almada e Ivan Cupertino, substituiria também, o antigo terminal localizado no centro da cidade. Assim, como o projeto de Oswaldo Arthur Bratke para a Estação Ferroviária de Uberlândia, o Terminal Rodoviário partiu do desenho de uma imensa cobertura, 
formada por sucessivos módulos em concreto armado, cuja estrutura também era independente dos cômodos locados sobre a mesma. ${ }^{7}$

$\mathrm{Na}$ Rodoviária dos arquitetos mineiros, a proposta feita mais de uma década depois da Estação Ferroviária de Uberlândia, demonstrava o mesmo partido, onde agora, os módulos se apresentariam como um sucessão de abóbodas invertidas, cada qual, sustentadas por três pilares. As associações são várias. Em comum vê-se na rodoviária a cobertura como elemento que avança frontal e posteriormente, criando sombra aos transportes e usuários, além de permitir a circulação cruzada de ar necessária para atenuar as altas temperaturas da região. Vê-se também, como na estação de Bratke, a cobertura que dá liberdade ao arranjo dos usos do edifício, permitindo ainda a permeabilidade visual do transeunte e facilitando a integração entre espaço interno e externo, além de partir da consideração de possíveis expansões.

A pesquisa do NUTHAU-UFU encontrou o edifício projetado para a Rodoviária de Uberlândia publicado no primeiro número da revista mineira Pampulha, Novembro/Dezembro de $1979 .{ }^{8}$ Em página dedicada aos projetos de Flávio Almada (Faculdade de Arquitetura da Universidade do Brasil, 1961), duas imagens apareceram do Terminal Rodoviário de Uberlândia.

97. Terminal Rodoviário Presidente Castelo Branco. Fonte: Arquivo Público de Uberlândia - NUTHAUFAUeD / UFU.

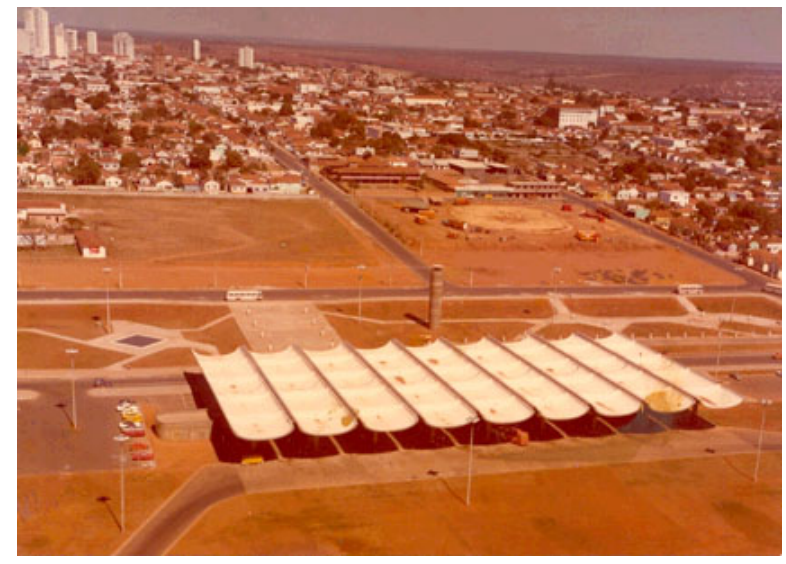

\footnotetext{
${ }^{7}$ As descrições do projeto partiram da ficha de inventário e de todo material coletado sobre o edifício
no NUTHAU-UFU.

${ }^{7}$ As descrições do projeto partiram da ficha de inventário e de todo material coletado sobre o edifício
no NUTHAU-UFU.

${ }^{8}$ Essa edição trazia uma mostra da produção de alguns arquitetos mineiros nos últimos dez anos, a partir de 1979.
} 


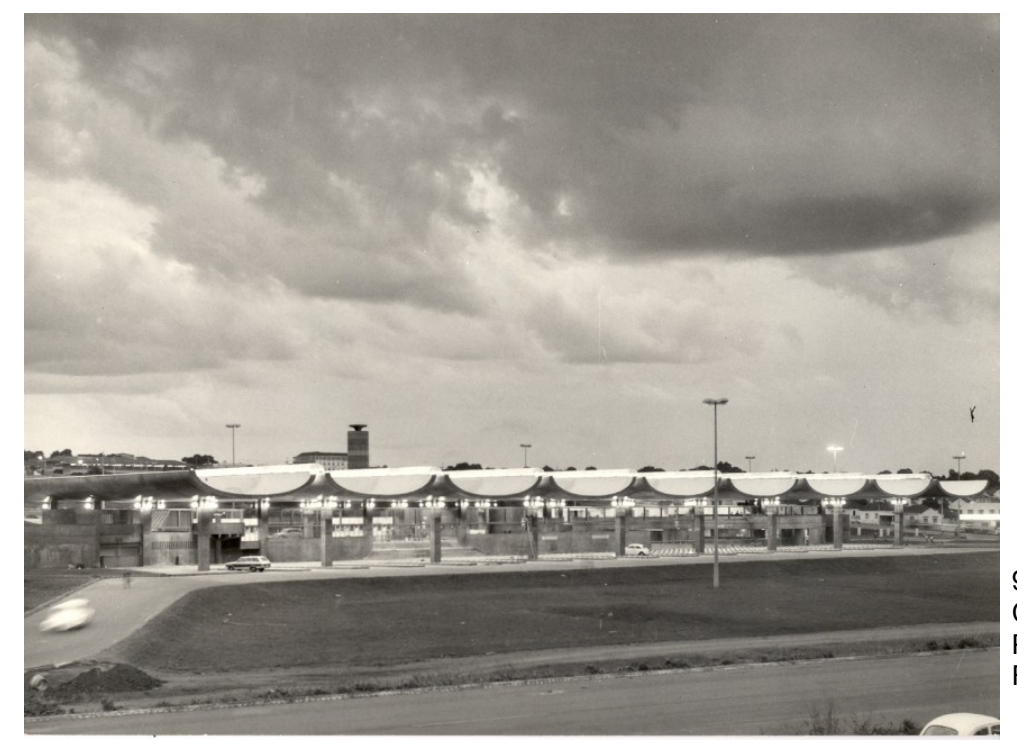

98. Terminal Rodoviário Presidente Castelo Branco. Fonte: Arquivo Público de Uberlândia - NUTHAUFAUeD / UFU.

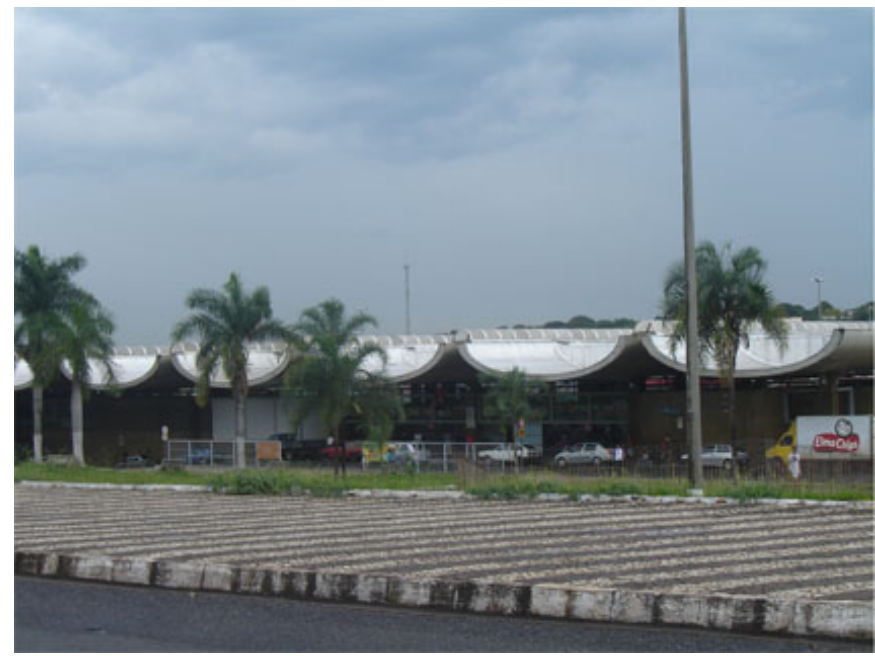

99. Terminal Rodoviário Presidente Castelo Branco. Fonte: NUTHAU-FAUeD / UFU.

Os companheiros do projeto para o Terminal Rodoviário, Fernando Graça e Ivan Cupertino, ambos formados pela atual Escola de Arquitetura da Universidade Federal de Minas Gerais, respectivamente em 1859 e 1962, tiveram outras atuações na cidade.

Ivan Cupertino, foi outro discípulo de João Jorge Coury, trabalhando como desenhista em seu escritório até se mudar para Belo Horizonte em 1952, ano em que ingressou no curso de arquitetura. Quando estudante, participou do concurso internacional para escolas de arquitetura, dentro da VI Bienal de São Paulo em 1961. Em 1959, Cupertino voltou a trabalhar com Coury como 
colaborador do projeto para a Praça Tubal Vilela, em Uberlândia. Na década de 1960, realizou o projeto para o Campus Umuarama e Hospital das Clínicas da Universidade Federal de Uberlândia. (GUERRA, 1998) Na mesma época, elaborou o projeto para a residência de Lígia Mendes de Figueiredo, onde fez uso da telha de fibrocimento que era assentada plana sobre a laje de piso, técnica que se difundiu em outras residências, próximas à zona central de Uberlândia, em bairros como o Lídice.

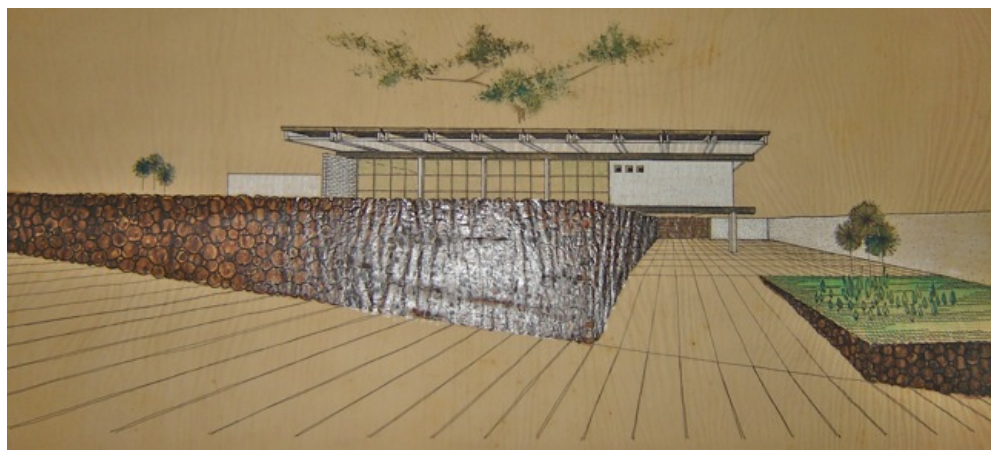

100. Res. Ligia Mendes Figueiredo. Fonte: NUTHAU-FAUeD / UFU.

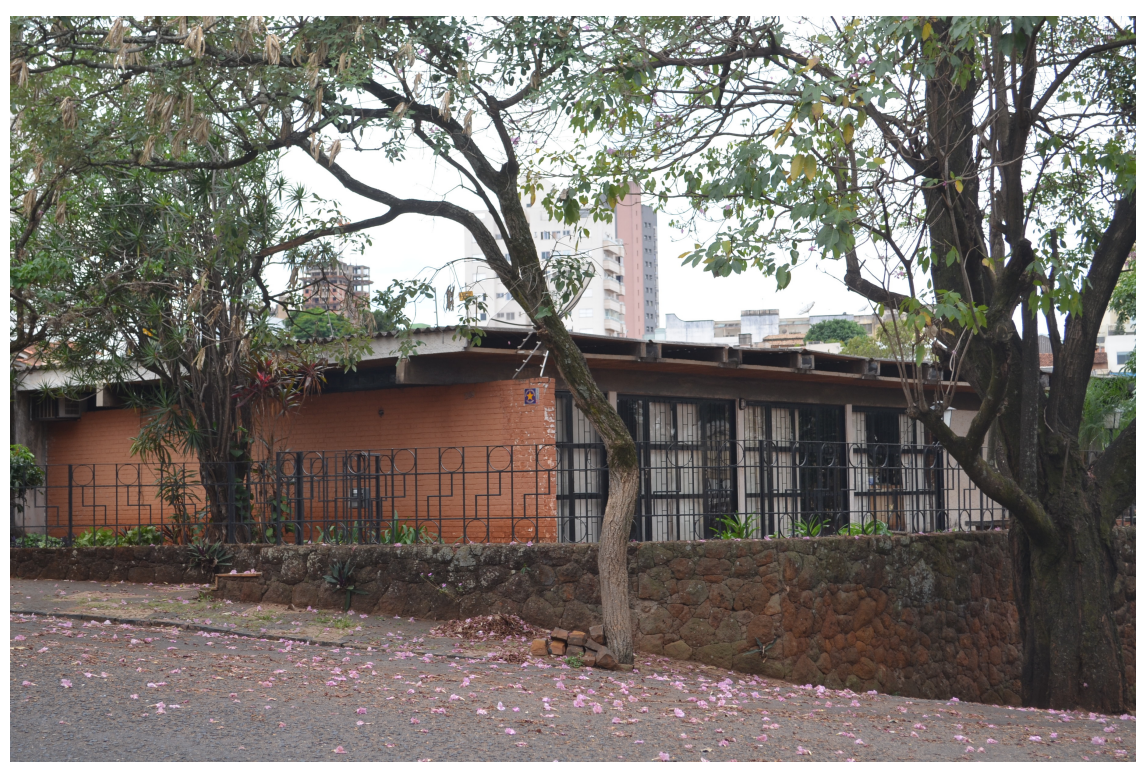

101. Res. Ligia Mendes Figueiredo. Fonte: Foto da autora.

Ainda quando estudante, em 1958, Fernando Graça projetou em Uberlândia a residência do Sr. Geraldo Migliorini, na zona central da cidade. O 
projeto foi premiado no mesmo ano pelo Instituto de Arquitetos do Brasil (IAB). ${ }^{9}$ Sua proposta trazia para a cidade uma arquitetura cuja concepção formal se distinguia pela composição de planos, levemente contrastados pela escolha dos materiais, sendo estes pedras, o tijolo aparente, pastilhas, painéis em madeira e cerâmica, e panos de vidro. Esse jogo de planos é evidenciado na fachada frontal, por exemplo, pela platibanda e peitoril do terraço - o qual integra os quartos no pavimento superior. A sucessão de vigas sobre o balanço, proporcionado pelo avanço da laje do pavimento superior, é singular no projeto. Aqui, Fernando Graça deixa com que a estrutura também desempenhe um papel estético, utilizando-a na composição da fachada, num jogo harmônico e ritmado entre linhas, planos e volumes.

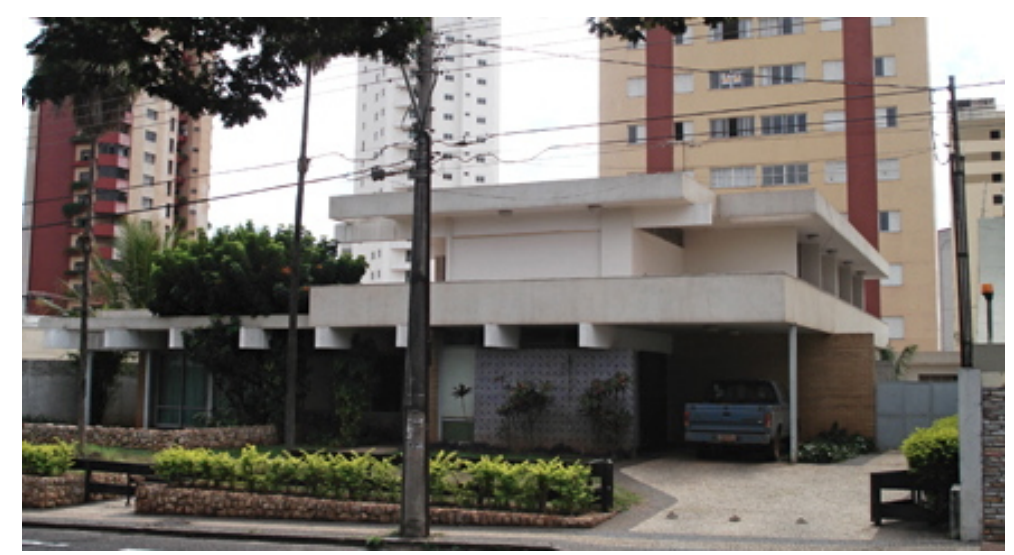

102. Res. Geraldo Migliorini. Fonte: NUTHAU-FAUeD / UFU.

O projeto para a Estação Ferroviária de Uberlândia - assim como a o Terminal Rodoviário Presidente Castelo Branco - demonstrou existir uma produção arquitetônica moderna no Triângulo Mineiro e Alto Paranaíba ligada ao desenvolvimento do seu sistema de transportes, como visto no primeiro capítulo, de extrema importância no processo do desenvolvimento econômico da região. A arquitetura moderna da Estação Ferroviária de Oswaldo Arthur Bratke na década

\footnotetext{
${ }^{9}$ As descrições do projeto partiram da ficha de inventário e de todo material coletado sobre o edifício no NUTHAU-FAUED / UFU.
} 
de 1960, ainda corresponderia ao ideário progressista local, associado à importância da região dentro de uma política de interiorização do Brasil $^{10}$, a qual teria seu grande momento no deslocamento da capital federal para o Planalto Central e a construção de Brasília.

\footnotetext{
${ }^{10}$ Ver capítulo 1.
} 


\section{A Verticalização nos Anos de 1960}

A moça passava confiante pelo passeio da rua Santos Dumont para cima do Uberlândia Clube. Ao aproximar-se da esquina, quase recebeu de cheio uma tromba dágua que alguém atirara de uma das janelas para a rua. Água de balde, de bacia, de jarro, cousas meio anacrônicas hoje em dia nas casas de bom gosto que dispõem de banheiro e chuveiro. Também pode ser água de objeto mais deselegante, porque o gesto de usar a rua como fundo de quintal privado é sinal evidente de gente que ainda pode usar vaso debaixo da cama. Claro que a gente ficou sabendo de que edifício atirou tanta água à rua, de uma vez, a ponto de causar susto de tamanha injúria à civilidade caseira e social! A moça andava mesmo azarada. Na volta, cuidou sensatamente de evitar as vizinhanças do prédio de apartamentos, receada de ficar molhada de todo. Passou pelo lado de lá, o da construção do arranha-céu. Pois não é que quase recebeu de cheio um tijolo que veio se espatifar no asfalto junto dela? Eis que veio me pedir para atacar os apartamentos construídos e em construção, porque para ela se mostraram armadilhas de matar transeuntes desavisados dos maus hábitos de moradores e de construtores. [... $]^{11}$

O texto citado acima, encontrado no Jornal Correio de Uberlândia, no fim do ano de 1960, demonstra que o processo de verticalização da cidade não era uma questão que incidia somente na tipologia de novas construções e no emprego de novas técnicas, mas também na incorporação inevitável da população em um novo modo de vida. Até a década de 1970 foram encontrados mais textos como este, no Jornal Correio de Uberlândia, reclamações ou crônicas. Nessas ultimas o texto objetivava claramente - através de enredos fictícios sobre o cotidiano de um morador de um prédio alto - persuadir a população de que havia a possibilidade de se viver bem em um edifício de apartamentos.

${ }^{11}$ EDIFÍCIOS Altos e as Falhas Sociais. Correio de Uberlândia, Uberlândia, 13 Dez. 1960. 
Já no final da década de 1950, Uberlândia experimentou a alteração da paisagem urbana da área central da cidade, através da construção do Edifício Tubal Vilela, projeto moderno de Ulpiano Muniz, de 1957, ao lado de outro exemplar menor construído pouco tempo antes, o Edifício Drogasil, divulgados na imprensa local como obras precursoras, vinculados ao progresso que vivia a região naqueles tempos. ${ }^{12}$

Nesse processo de verticalização vinculado à produção de arquitetura moderna no Triângulo Mineiro e Alto Paranaíba, que coincide aqui com a construção de Brasília e o desenvolvimento econômico da região, a produção de dois arquitetos se destacam. Germano Gultzgoff e Paulo de Freitas, ambos formados pela Faculdade de Arquitetura da Universidade Mackenzie em início da década de 1950, residentes em suas cidades de atuação, respectivamente, Uberaba e Uberlândia. Esses dois arquitetos terão um papel significativo na difusão da arquitetura moderna nessas cidades, aliado, principalmente ao processo de verticalização, eclodido nos anos de 1960.

Germano Gultzgoff foi o arquiteto encontrado pela pesquisa do NUTHAU-UFU com uma quantidade expressiva de obras modernas na cidade de Uberaba, onde dedicou a maior parte de sua carreira. De família russa, nasceu em São Paulo e foi para Minas Gerais na juventude, onde estudou por três anos na escola de Minas, em Ouro Preto, antes de ingressar na Universidade Mackenzie, em São Paulo.

Na Mackenzie cursou o básico de engenharia civil e diversas cadeiras da arquitetura, formando-se em 1950, em uma turma de dezoito alunos. Na época de seus estudos, o curso para formação de engenheiro-arquiteto era vinculado à Escola de Engenharia da Universidade Mackenzie, onde diversas disciplinas técnicas eram dadas em ambos os cursos, engenhara e arquitetura. (LAZZARIN; SOUZA ALVES; CAPPELLO, 2010)

\footnotetext{
${ }^{12}$ Ver capítulo dois: Um Imaginário na Dinâmica Construtiva do Triângulo Mineiro.
} 
Nas palavras de Germano Filho, esse tipo de formação deu à Gultzgoff grande qualidade ao seu desenho e muito conhecimento estrutural. Com relação à este ultimo, ele cita o pai que sempre dizia "arquiteto de hoje não sabe nada de estrutura, arquitetura virou corte e costura." Germano Filho conta que quando estudante, o pai estagiou no escritório de Oswaldo A. Bratke, formado engenheiro-arquiteto também na Universidade Mackenzie, em 1931, autor das estações ferroviárias de Uberlândia e Uberaba, sendo um período importante na na formação de Gultzgoff. (LAZZARIN; SOUZA ALVES; CAPPELLO, 2010)

Sua carreira profissional em Uberaba se inicia quando recebe o convite para o projeto de uma reforma na residência do pai de um amigo, ainda da época de Ouro Preto. Ao chegar na cidade, recebe outra proposta, um projeto para a fábrica de papel de Edgar Rodrigues da Cunha - já demolida - pra quem ainda viria fazer outros projetos na cidade. Com o surgimento de outras propostas, Gultzgoff acaba por se estabelecer em Uberaba, atuando na cidade até 2008, quando falece. Seu primeiro grande projeto em Uberaba foi o Hospital Hélio Angotti, financiado pela Associação de Combate ao Câncer do Brasil Central, sob primeira denominação de Hospital de Clínicas Mário Palmério ${ }^{13}$, então deputado federal que deu apoio à instituição. Sua inauguração se deu em 4 de Maio de 1958. (LAZZARIN; SOUZA ALVES; CAPPELLO, 2010)

Na década de 1970, Gultzgoff estabeleceu escritório junto à construtora Urbano Salomão, cuja sociedade se deu até o fim de sua carreira. Com a parceria, inicia-se um período de intenso trabalho para o arquiteto. Na década de 1980, Germano se envolve na vida política de Uberaba. Trabalha na Secretaria de Obras, candidata-se a prefeito, funda o Partido Verde. Auxilia Mário Palmério a criar a FIUBE, atual UINUBE (Universidade de Uberaba), realizando diversos projetos para prédios da universidade, muitos já bastante descaracterizados.

\footnotetext{
${ }^{13}$ Mario Palmério era educador, político, embaixador, literato e sucessor de Guimarães Rosa na Academia Brasileira de Letras, foi idealizador da cidade universitária de Uberaba.
} 
Nesta universidade, lecionou no curso de engenharia por 20 anos. (LAZZARIN; SOUZA ALVES; CAPPELLO, 2010)

Dentre as obras executadas em Uberaba, encontram-se residências, prédios de apartamentos, comerciais e de uso misto, prédios institucionais, industriais e diversas fazendas. Para efeito de citação, dentro das obras encontradas pela pesquisa do NUTHAU-UFU, são de sua autoria o Edifício Chapadão (1975), Galeria Fausto Salomão (1972), Edifício Pedro Salomão (1964), Edifício Olavo Mendes (19??), prédio para a Faculdade de Filosofia Tomás de Aquino (19??), a residência de Edgar Rodrigues da Cunha (19??), dentre diversos outros projetos. Projetou edifícios em outras cidades, vários em Brasília, onde dispensou uma oferta de trabalho logo quando se mudou para Uberaba. Na nova capital, à exemplo, projetou a residência para Delfim Neto, o Centro Comercial Urbano Salomão e a Granja Riacho Fundo.

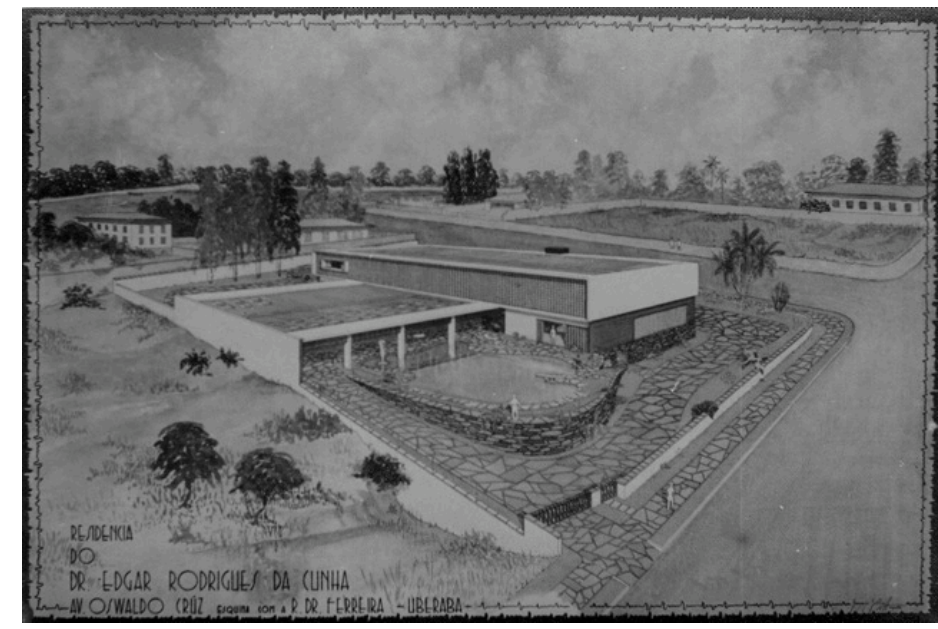

103. Res. Edgar Rodrigues da Cunha. Fonte: NUTHAU-FAUeD / UFU.

Coincidindo com o despertar para a verticalização de Uberaba, pode-se dizer que os projetos de Gultzgoff para os novos edifícios altos, utilizando-se da linguagem moderna, foram um importante vetor de difusão da nova arquitetura na cidade. Há de se considerar, que em meados dos anos de 1960, tal tipologia exerceu na paisagem urbana de Uberaba, um forte ressalto. Destacada no 
panorama da cidade, onde a nova arquitetura moderna brasileira ainda não havia alcançado seu espaço, pode-se dizer que a linguagem moderna vinculada à tipologia de edifícios altos, exerceu papel fundamental no que diz respeito à difusão da arquitetura moderna.

O Edifício Pedro Salomão ${ }^{14}$ é provavelmente um dos primeiros prédios verticais de Uberaba. Seu projeto data de 1964 e seu programa constitui em salas comerciais no pavimento térreo e apartamentos nos demais pavimentos. Está situado no centro original de Uberaba, onde estão concentrados comércios e serviços, diversos equipamentos urbanos, edifícios institucionais, as principais vias, além do patrimônio arquitetônico da cidade, com edifícios de diversos períodos de sua história.

Foi implantado em um terreno de esquina, cujas lojas no pavimento térreo foram voltadas para a via de maior caráter comercial, à Rua Manoel Borges. Pela rua Satyro S. Oliveira, uma via sem saída, Gultzgoff loca o acesso principal do prédio, facilitando a entrada e saída dos moradores do edifício uma vez que se trata de uma via com pouco trânsito. É por essa mesma via que o morador chega à parte posterior do edifício, onde se localiza a entrada para o estacionamento privativo.

São ao todo doze andares, com quatro unidades habitacionais por andar - com exceção do $12^{\circ}$, onde existem dois dúplex - e sete lojas no pavimento térreo, voltadas para a periferia do prédio, defronte à calçada. Tanto a circulação do Edifício Pedro Salomão quanto sua infra-estrutura predial foi fixada centralmente à planta do projeto, o que otimizou a funcionalidade da obra. Nesta porção, o arquiteto locou dois elevadores e uma caixa de escada enclausurada para circulação vertical, e prumadas visitáveis transpassando todos os pavimentos.

\footnotetext{
${ }^{14} \mathrm{~A}$ descrição e análise do edifício partiram de sua ficha de inventário, assim como todo material elaborado e coletado pelo NUTHAU-FAUeD / UFU.
} 
Sua estrutura foi executada em concreto armado com modulação em vãos de 3,00 x 4,50 metros, o que corresponde à uma solução em planta livre. Os fechamentos foram feitos em bloco cerâmico, elementos vazados como os cobogós cerâmicos colocados nas áreas de serviço e cerâmica branca nas empenas cegas. Em uma das fachadas, destacam-se os fechamentos em metal e vidro, dispostos de modo a preencher todo o pé-direito de cada pavimento-tipo.

Volumetricamente, o arquiteto é certeiro no equilíbrio em que emprega todos os elementos, utilizando esteticamente do contrate entre as cores e texturas próprias de cada revestimento, na demarcação de cada pavimento-tipo utilizando-se da própria estrutura do prédio, as sacadas que levemente se sobressaem do todo, sem conflitos de composição. A presença do cobogó é marcante na volumetria do Edifício Pedro Salomão, principalmente nas elevações onde o arquiteto o emprega junto às empenas cegas, revestidas em cerâmica clara. Gultzgoff dedicou declaradamente o projeto ao arquiteto Oswaldo A. Bratke, com o qual teve uma breve convivência no início da carreira. Muitos dos materiais escolhidos por Gultzgoff para o Edifício Pedro Salomão partiram da influência dos projetos de Bratke.

O Edifício Pedro Salomão faz parte do processo histórico da região, aliando a concepção moderna de projeto ao despertar para a verticalização das principais cidades do Triângulo Mineiro e Alto Paranaíba, participando ainda do encadeamento de um novo modo de morar, que incluíam nesse momento as principais cidades da região e maiores cidades do interior do país. Não só na volumetria e no uso de elementos fartamente difundidos pela "nova arquitetura brasileira", o moderno se encontra presente também na racionalidade com que o arquiteto distribui o programa e no uso consciente das novas técnicas construtivas. O desenho e o rigor na execução do Edifício Pedro Salomão, assim como seu ótimo estado de preservação, coloca a obra como um importante 
patrimônio arquitetônico da cidade, facilmente reconhecido na paisagem urbana da região central de Uberaba.

104. Edifício Pedro Salomão. Fonte: NUTHAU-FAUeD / UFU.

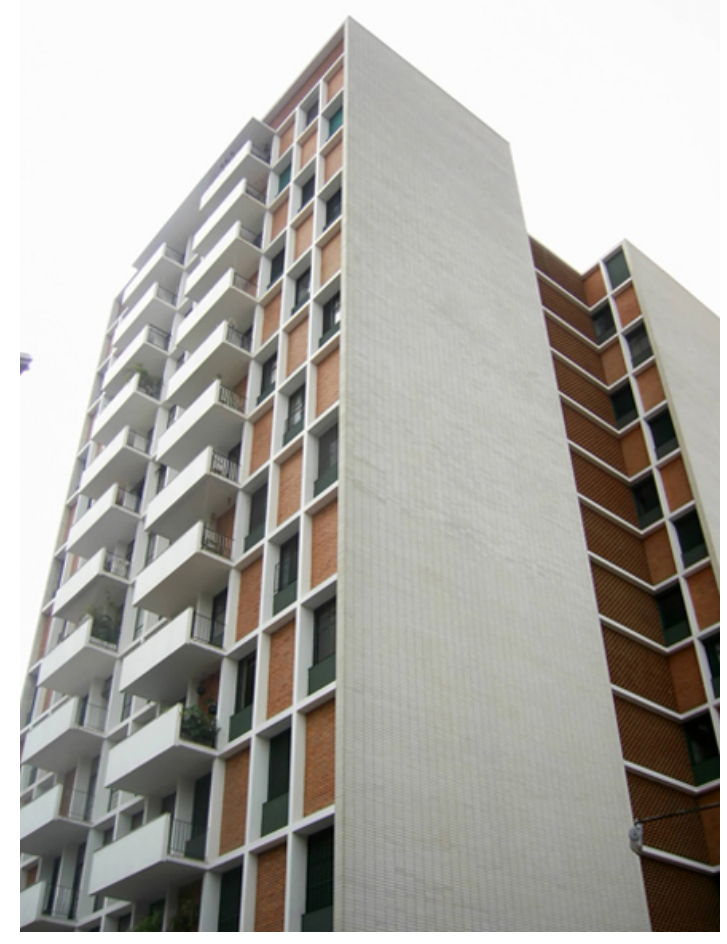

105. Ed. Pedro Salomão. Fonte: NUTHAU-FAUeD / UFU.

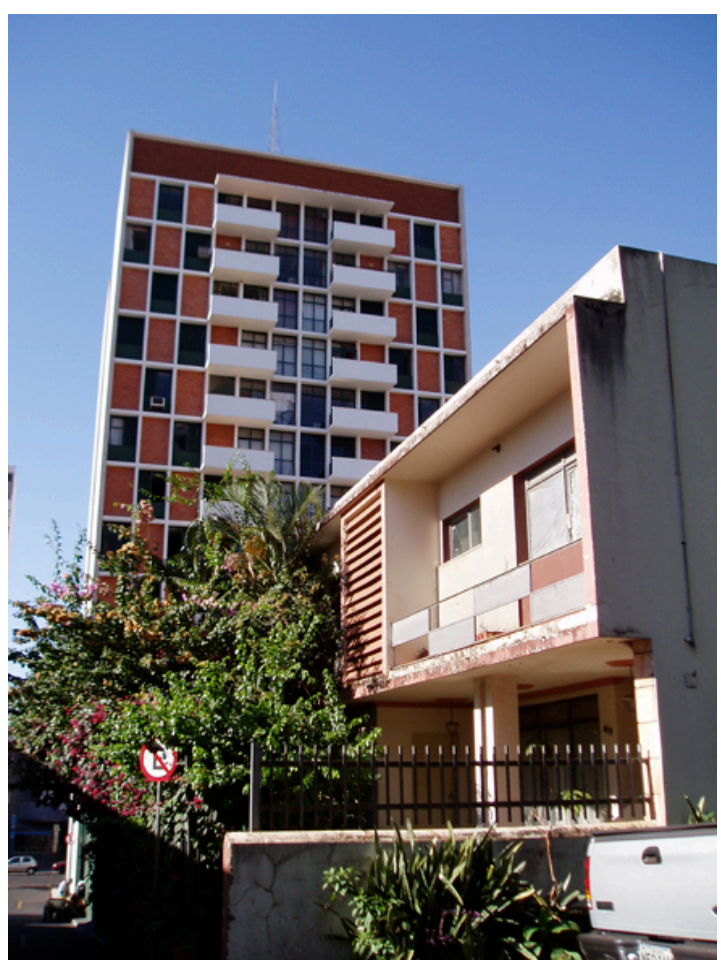


106. Edifício Pedro Salomão. Fonte: NUTHAU-FAUeD / UFU.
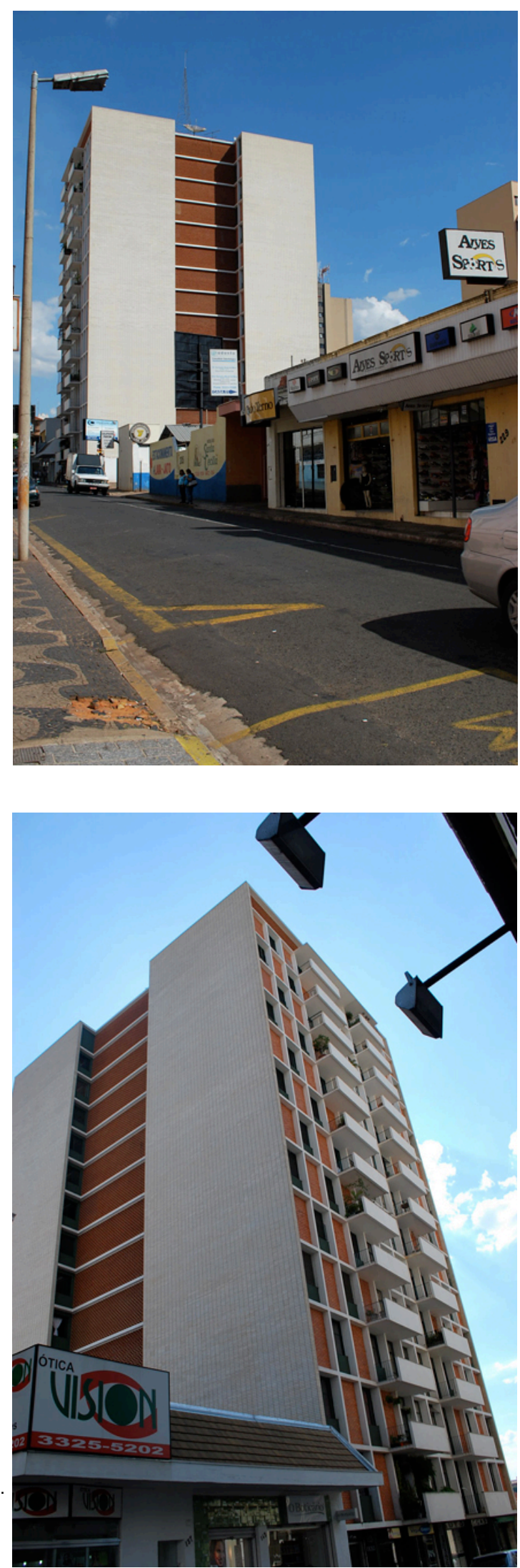

Edifício Pedro Salomão.

Fonte: NUTHAU-FAUeD / UFU. 
108. Edifício Pedro Salomão. Fonte: NUTHAU-FAUeD / UFU.

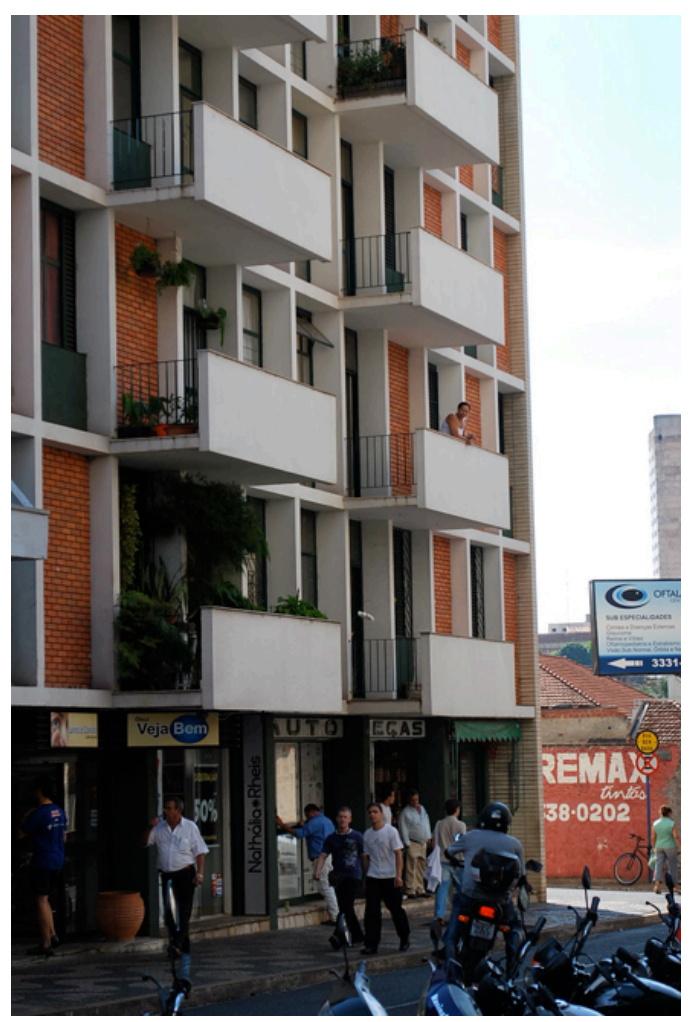

109. Edifício Pedro Salomão. Fonte: NUTHAU-FAUeD / UFU.

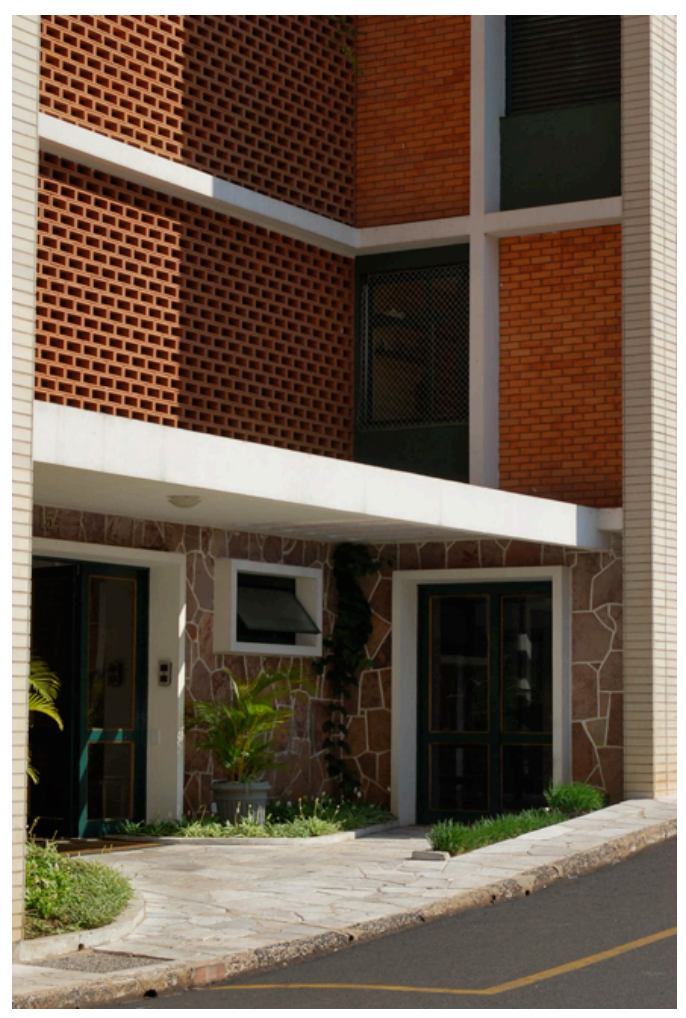


110. Edifício Pedro

Salomão.

Fonte: NUTHAU

FAUeD / UFU.

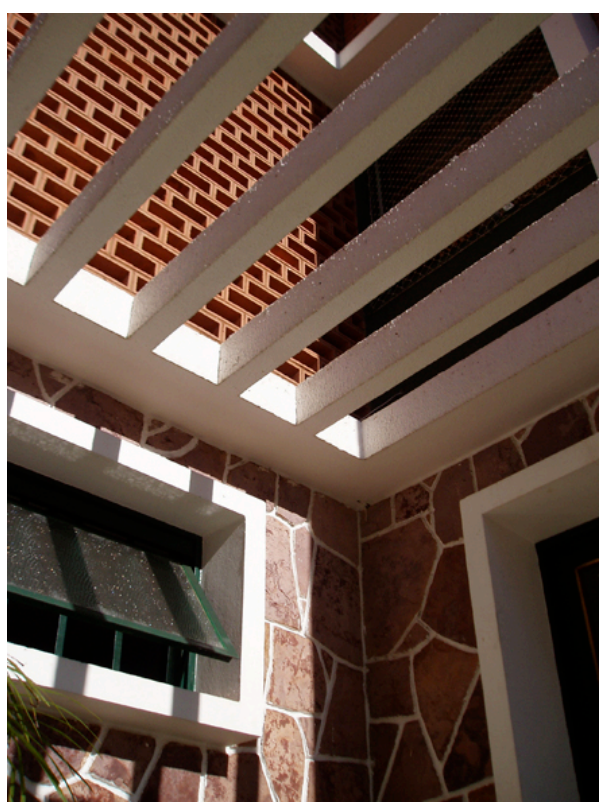

111. Edifício Pedro Salomão. Fonte: NUTHAU-FAUeD / UFU.
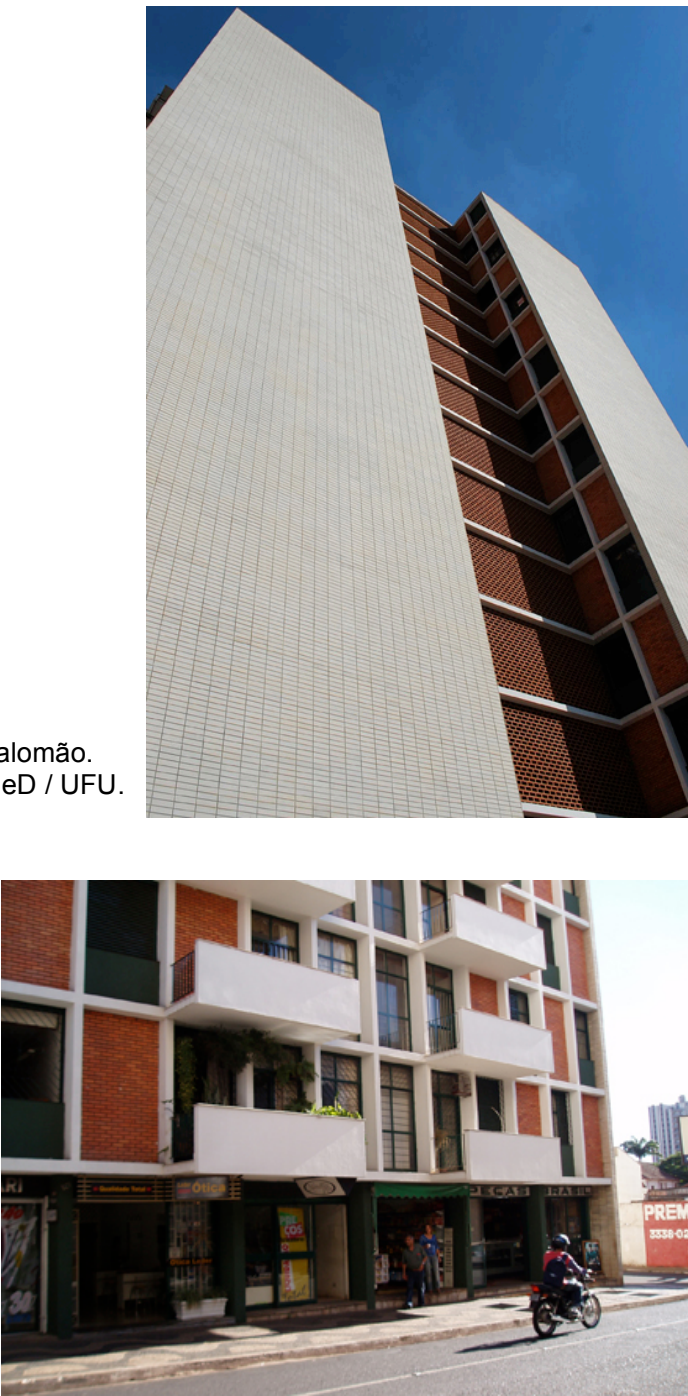

112. Edifício Pedro Salomão. Fonte: NUTHAU-FAUeD / UFU. 
Nas décadas de 1970 e 1980, a pesquisa do NUTHAU-FAUeD / UFU encontrou outro arquiteto que se destacou na produção da arquitetura moderna de Uberaba. Wagner Schroden, filho de imigrantes alemães que se estabeleceu na cidade ainda muito jovem, junto à família, se formou em 1966 na Escola de Arquitetura da Universidade Federal de Minas Gerais (EA-UFMG), antiga Escola de Arquitetura de Belo Horizonte $(\mathrm{EABH})$, atuando na capital mineira por dezesseis anos, antes de voltar à Uberaba. Lá, foi professor da EA-UFMG, lecionou artes na FUMEC (Fundação Municipal para Educação Comunitária), foi representante da Secretaria de Viação e Obras do estado e coordenador chefe do grupo regional do SERFHAU (Serviço Federal de Habitação e Urbanismo). (MANHAS; VILLELA; OLIVEIRA, 2009).

Schroden faleceu precocemente em 1987, aos 49 anos, mas teve uma atuação fecunda, ainda que com pouco tempo de profissão. Projetou em Belo Horizonte, em cidades do Triângulo Mineiro, Brasília, Ribeirão Preto, e em cidades da América Latina, como em Assunção, no Paraguai, onde elaborou o projeto para o Clube Guarani. Em Uberaba, a maior parte do seu trabalho foi na área de planejamento urbano, tendo atuado no Departamento de Obras da Prefeitura Municipal, onde realizou inúmeros trabalhos de urbanização de bairros. (MANHAS; VILLELA; OLIVEIRA, 2009).

Seu conjunto arquitetônico na cidade inclui diversas obras públicas, como a Biblioteca Municipal e a Sede do Ministério da Fazenda. Realizou o projeto urbanístico e arquitetônico para o Campus Universitário da FIUBE, atual UNIUBE, o Plano diretor e projeto para os blocos da Administração do Parque de Exposições da Associação Brasileira dos Criadores de Zebu - ABCZ. No período em que se fixou em Uberaba, de meados da década de 1970 a meados dos anos de 1980, ajudou a transformar o panorama da cidade em seu ainda corrente processo de verticalização, realizando diversos projetos para prédios de uso 
misto, como o Edifício Karajás e o Edifício Geraldino Rodrigues da Cunha, ambos de 1974.

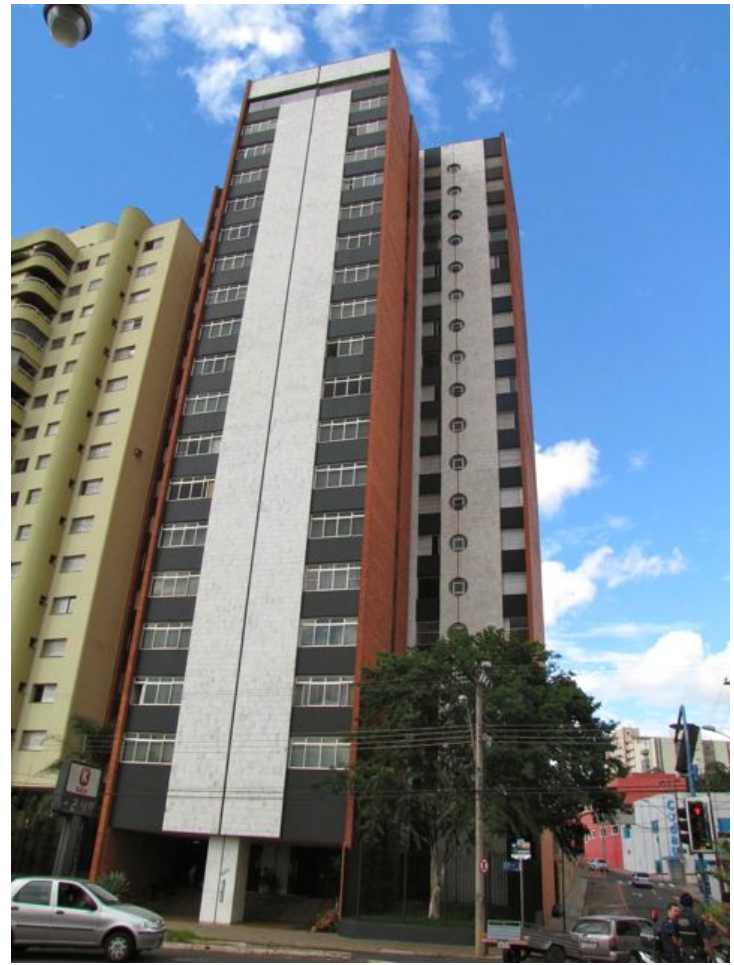

113. Edifício Karajás. Fonte: NUTHAU-FAUeD / UFU.

114. Edifício Geraldinho Rodrigues da Cunha. Fonte: NUTHAU-FAUED / UFU.

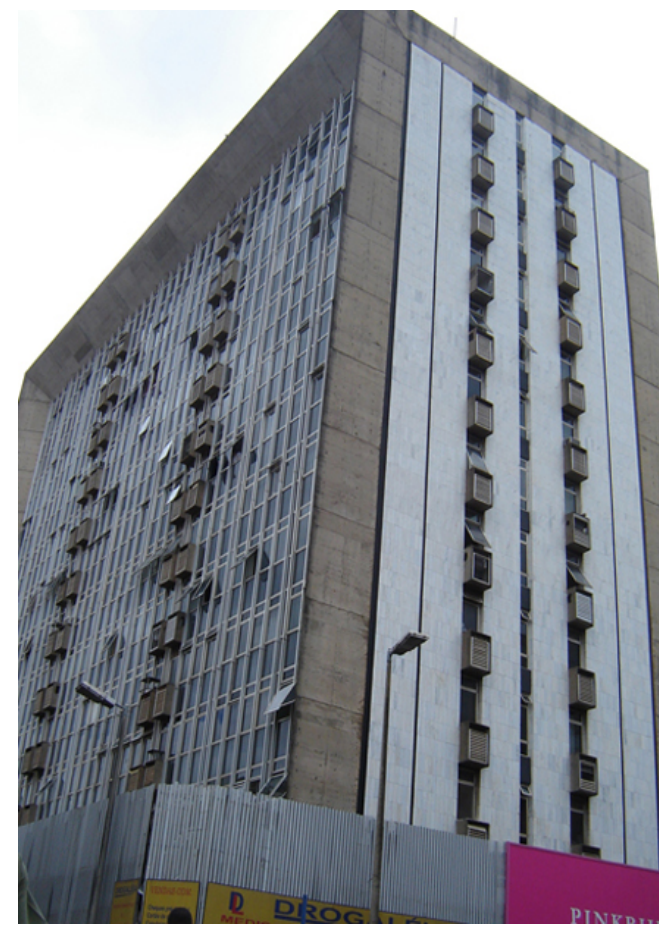


No processo de verticalização regional, a pesquisa do NUTHAU-UFU também revelou um arquiteto que se destacou na cidade de Uberlândia. Paulo de Freitas, nascido em 1930 nessa cidade, foi um dos arquitetos influenciados pelo trabalho de João Jorge Coury. ${ }^{15}$ Muda-se para São Paulo em 1944 para completar os estudos e ingressa em 1950 na Escola de Arquitetura da Universidade Mackenzie, formando-se em 1955.

Quando estudante, frequentou rodas de debates com estudantes da FAU-USP e com os mestres João Vilanova Artigas e Eduardo Corona, foi colaborador na elaboração técnica da $1^{\text {a }}$ Bienal de Arquitetura em São Paulo, em 1951, fez três anos de estágio com o arquiteto tcheco Adolf Franz Heep, o que Ihe permitiu a convivência e estrita ligação com o repertório das primeiras gerações modernas. Após formado, permaneceu em São Paulo por quatro anos, com escritório associado ao arquiteto José Tobias de Andrade, projetando arquitetura residencial unifamiliar. Volta à Uberlândia em 1959, período que coincidiu com o despertar da cidade para a verticalização, incentivada pelo empresário Tubal Vilela. (LAURENTIZ, 1993).

Somada à prática profissional, Paulo de Fretas ainda atuou como professor, dando aulas no curso de Decoração da Universidade Federal de Uberlândia, sendo também um de seus fundadores e ajudando a criar mais três, Artes, Música e Comunicação Visual. Em 1970, Paulo de Freitas assumiu a diretoria de obras da Prefeitura Municipal de Uberlândia. (LAURENTIZ, 1993).

Paulo de Freitas projetou o quarto edifício de apartamentos de Uberlândia, o Edifício Itaporã, de 1960, através do qual conseguiu outros trabalhos para a mesma tipologia, como o Edifício Itacolomy, de 1962, e o Edifício Fraternidade, de 1964, três edifícios construídos bem próximos, situados à Av. Santos Dumond, destacaram-se na paisagem urbana da área central da

\footnotetext{
${ }^{15} \mathrm{O}$ trabalho de João Jorge Coury foi tratado no capítulo 2.
} 
cidade. $\mathrm{O}$ arquiteto ainda projetou diversas residências, utilizando-se do vocabulário moderno nos seus projetos. (LAURENTIZ, 1993).

115. Edifício Itaporã. Fonte: NUTHAU-FAUeD / UFU.

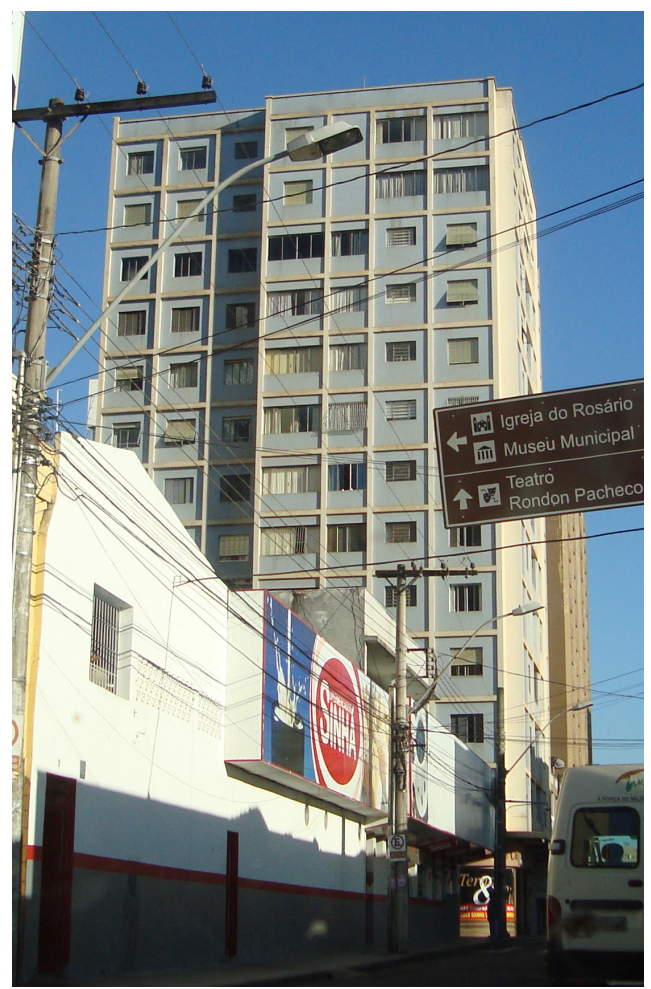

116. Edifício Fraternidade Fonte: NUTHAU-FAUeD UFU.

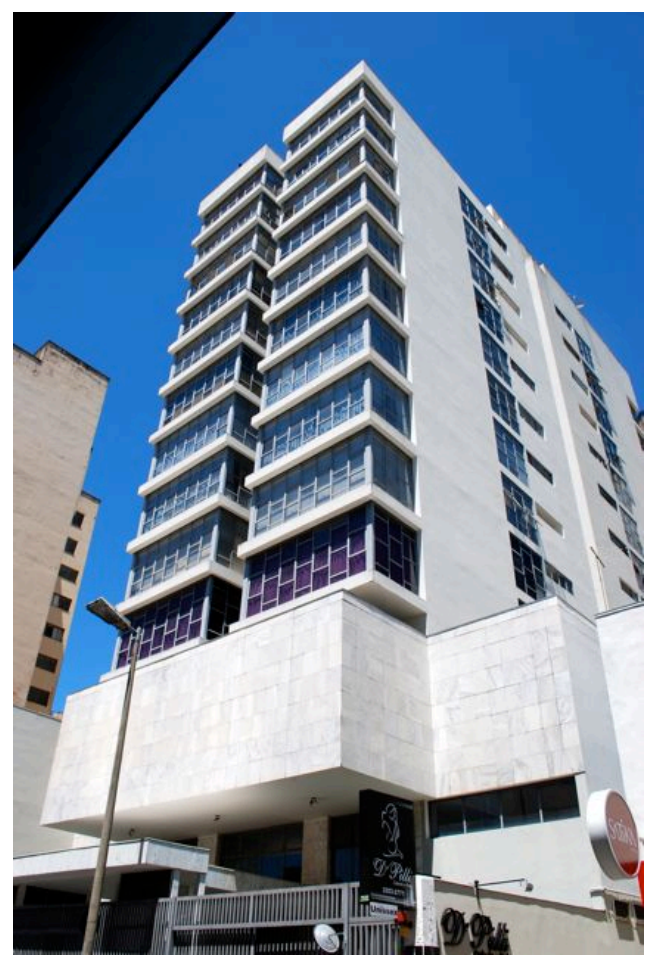


117. Edifício Itacolomy. Fonte: NUTHAU-FAUeD / UFU.

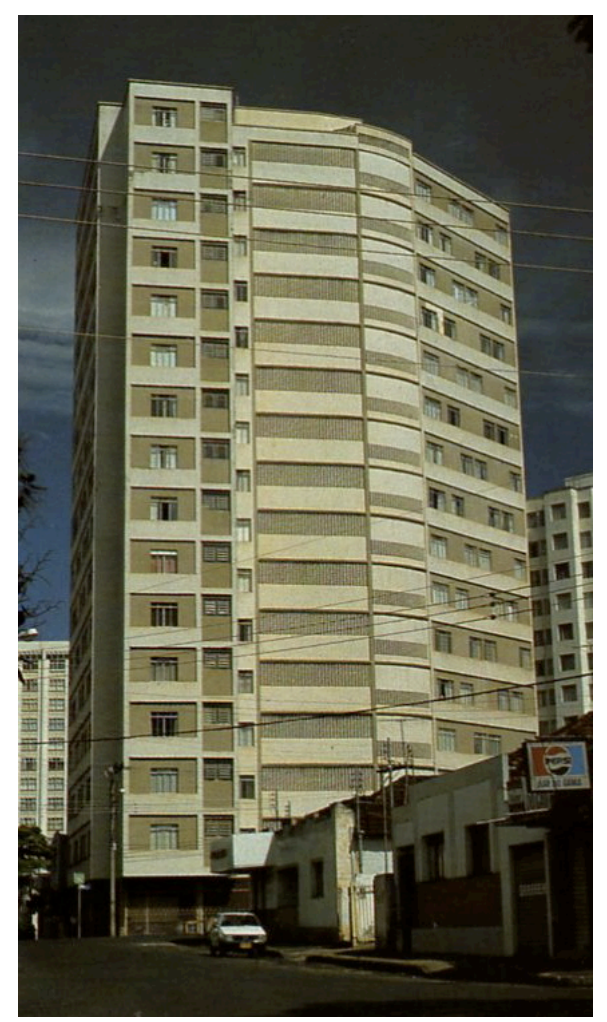

O Edifício Itacolomy ${ }^{16}$, para moradia multifamiliar, foi projetado por Paulo de Freitas em 1960. A proposta era um edifício com quinze pavimentos, cada qual com três apartamentos, dando um total de quarenta e cinco unidades de habitação. Localizado no cruzamento de duas importantes vias, o Itacolomy se destaca na paisagem central de Uberlândia por sua volumetria peculiar. $O$ formato que se assemelha a um "J" não denuncia somente uma escolha formal, mas também uma estratégia de implantação para um terreno de esquina. $O$ partido possibilitava que, através de uma concepção volumétrica, o transeunte melhor reconhecesse o edifício como um todo no panorama mais denso da cidade. Somado a isso, permitia à cada morador uma maior diversidade de visadas desde seu interior, além da possibilidade de maiores anglos de visão para o cenário circundante.

\footnotetext{
${ }^{16}$ A descrição e análise do edifício partiram de sua ficha de inventário, assim como todo material elaborado e coletado pelo NUTHAU-UFU.
} 
Todos os apartamentos possuíam dois acessos - um principal, para a sala de estar e um de serviços - três quartos, banheiro, sala e cozinha integrada com a área de serviço. Em dois dos três tipos de apartamentos, o arquiteto organiza o programa a partir de uma circulação central, na outra tipologia, a sala faz o papel de centro distribuidor dos espaços, utilizando de um corredor apenas para distribuição dos quartos e banheiro. Sem dúvidas, é uma organização calcada na funcionalidade para um novo modo de viver, ainda que não apresente alternativas muito ousadas. Há de se considerar, nessa transformação, os embates entre o arquiteto moderno, o mercado imobiliário, o cliente e seus costumes.

O Edifício Itacolomy possuía seu térreo aberto, o que propiciava outra maneira de se relacionar com o espaço público circundante, pela alternativa de circulação e passagem presenteada ao pedestre. Nele, foram colocados dois elevadores e um conjunto de escadas, rodeados por jardins. A escada, desenhada em formato triangular, originava um átrio central que permitia a visualização de todos os pavimentos. Posteriormente, o térreo foi fechado e transformado em estacionamento.

A estrutura do prédio foi feita em concreto armado, com fechamento em alvenaria e elementos vazados. A proposta do arquiteto, por colocar cobogós nos patamares das escadas e nos cômodos correspondentes às áreas de serviço, possibilitava a ventilação e iluminação natural desses locais. A presença dos cobogós é marcante nas fachadas do Itacolomy, caracterizadas pela composição destes com a disposição das esquadrias. A fachada curva foi uma inovação para a época, revelava as possibilidades de construção pelo advento das novas tecnologias. 


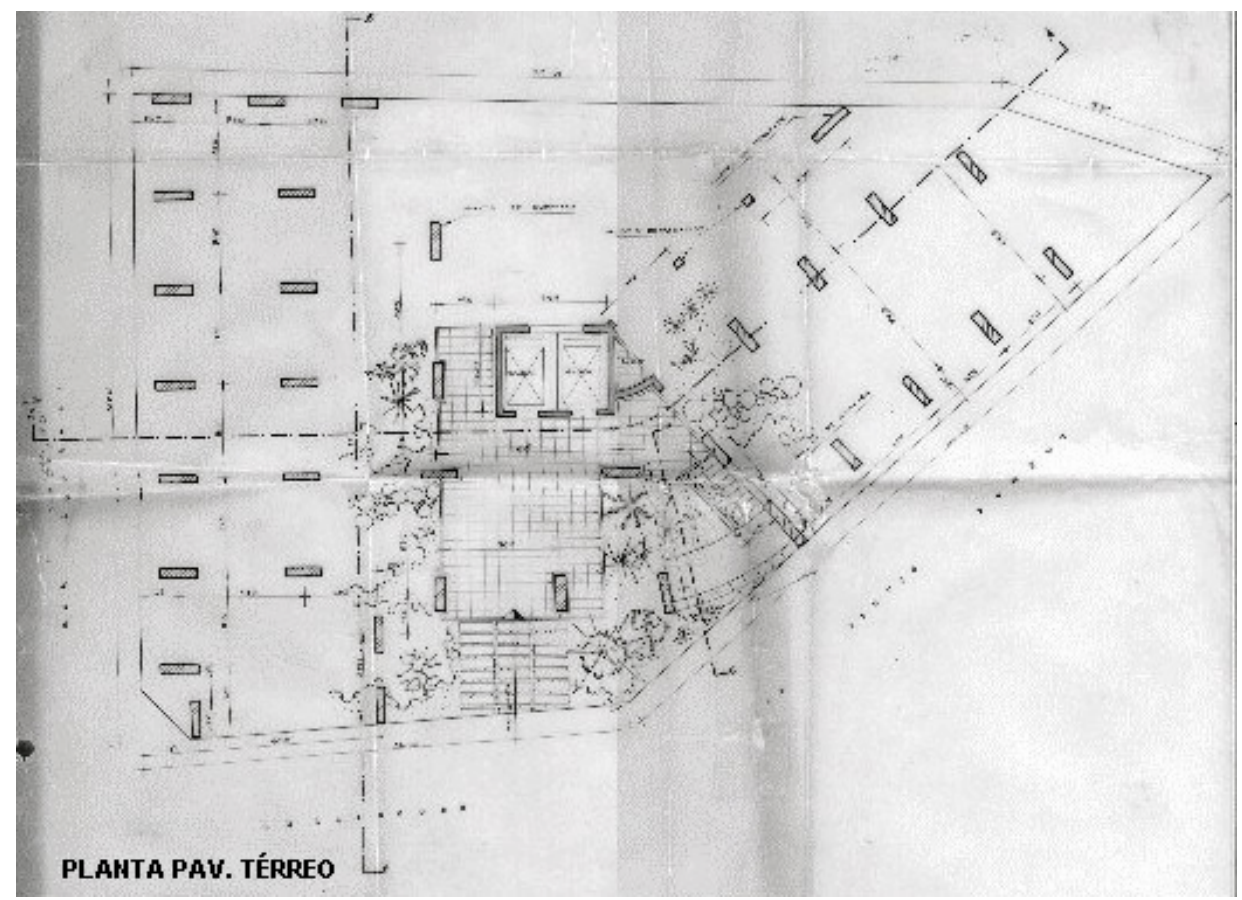

118. Edifício Itacolomy. Planta Térreo. Fonte: RIBEIRO; MORAIS, 2001 - NUTHAU-FAUeD / UFU.

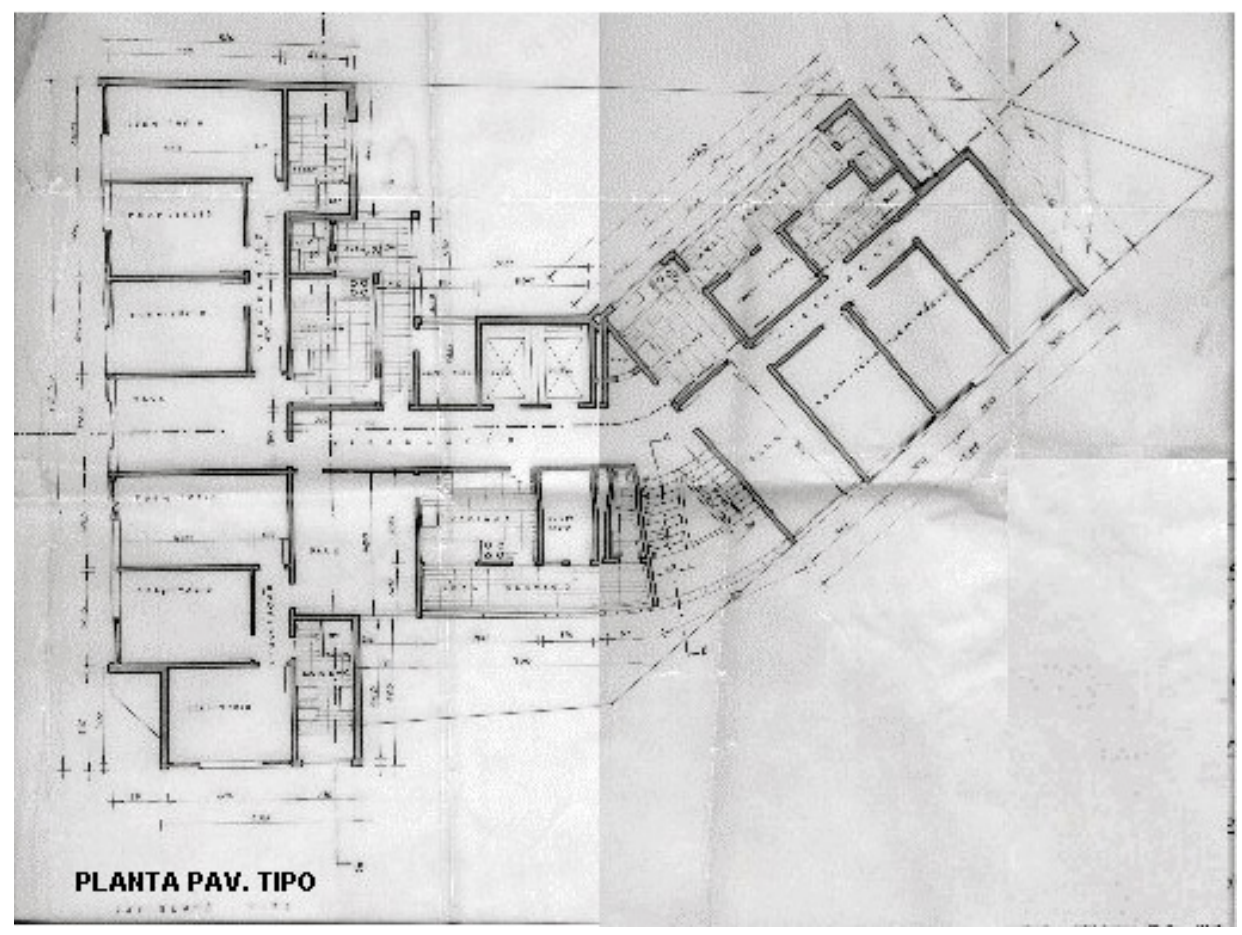

119. Edifício Itacolomy. Planta Térreo. Fonte: RIBEIRO; MORAIS, 2001 - NUTHAU-FAUeD / UFU. 
120. Edifício Itacolomy.

Fonte: NUTHAU-

FAUeD / UFU.

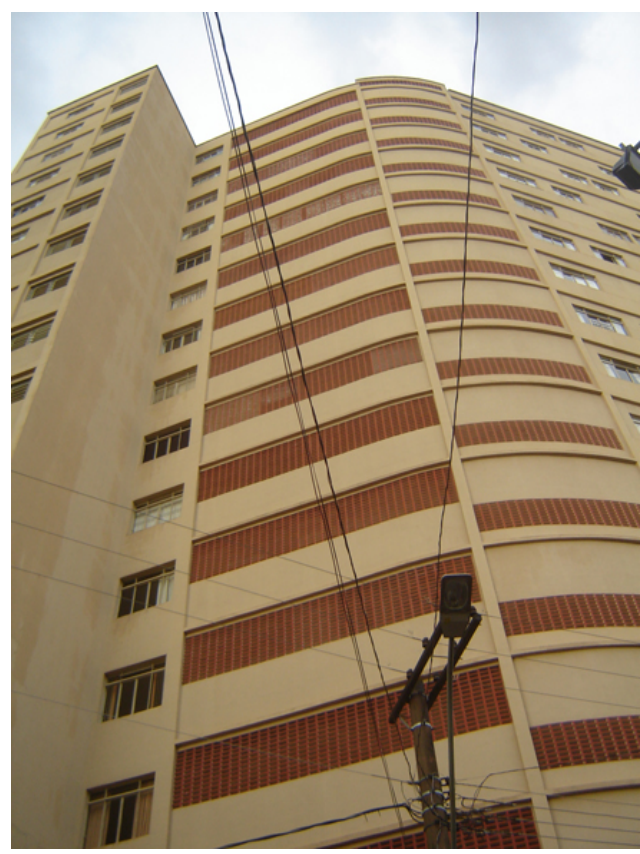

121. Edifício Itacolomy Fonte: NUTHAU-

FAUeD / UFU.

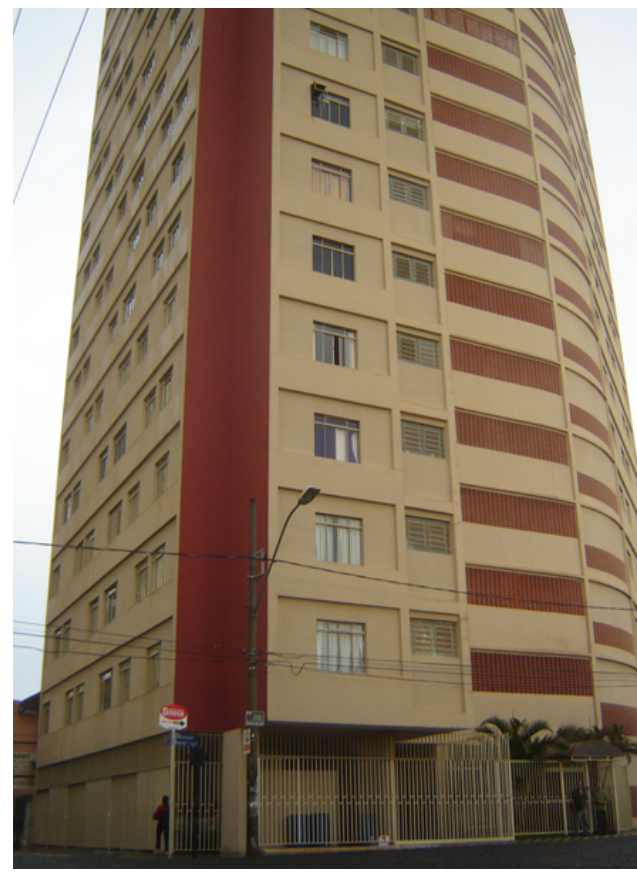

122. Edifício Itacolomy. Fonte: NUTHAU-FAUeD I UFU.

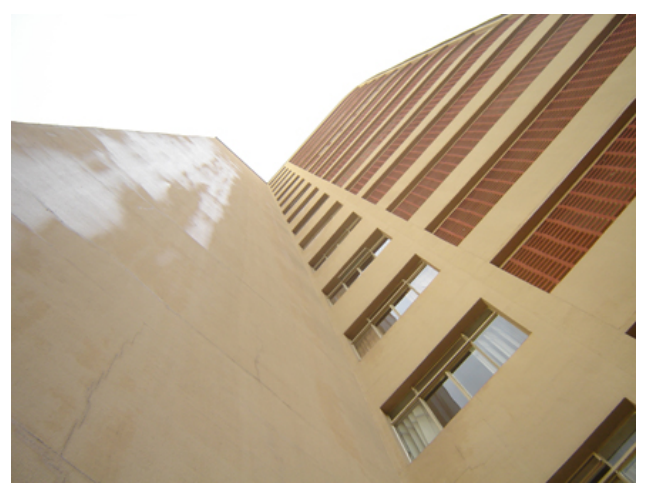


123. Edifício Itacolomy. Fonte: NUTHAU-FAUeD / UFU.

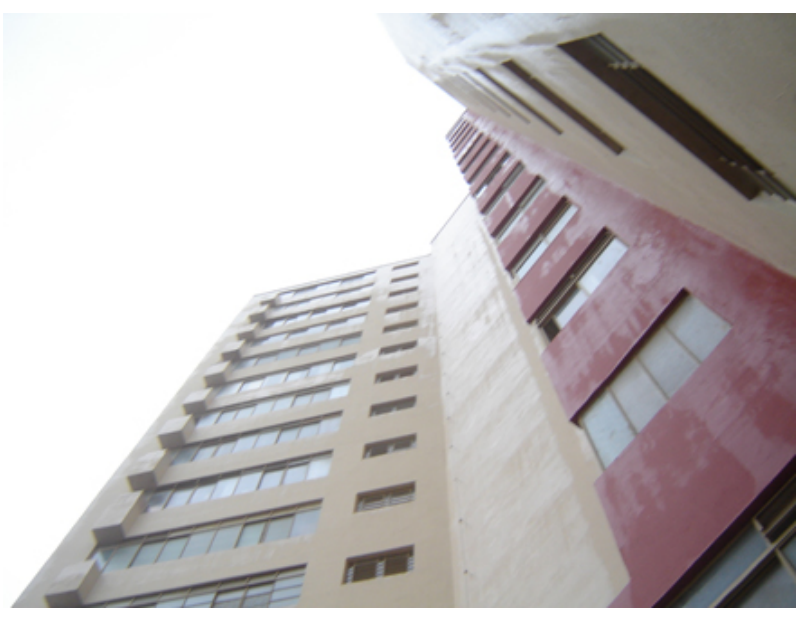

Tanto Germano Gultzgoff quanto Paulo de Freitas estudaram arquitetura na Universidade Mackenzie, segundo curso na área do estado de São Paulo. O curso de engenheiro-arquiteto foi fundado em 1917 e era um desmembramento do curso de engenharia, um dos que comporia a Escola de Engenharia Mackenzie College. Anterior à este, existia o curso de arquitetura vinculado à Escola Politécnica de São Paulo, desde 1894, o qual se destacava da Escola de Belas Artes do Rio de Janeiro por seu maior rigor técnico. Era um curso encarado como uma da especialidades da engenharia. (STOCKLER; BREIA, 2005)

O curso de engenheiro-arquiteto da Universidade Mackenzie era vinculado à Universidade de Nova lorque. Os alunos formados obtinham o título de engenheiro-arquiteto, e ainda tinham a possibilidade de receberem um diploma da escola norte-americana, o que possibilitava o exercício da profissão também nos EUA. O curso da Mackenzie foi fundado nos moldes das universidades norte-americanas, onde seu fundador, Christiano Stockler das Neves ${ }^{17}$, havia completado seus estudos em arquitetura. Tinha como base uma formação caracterizada pelos métodos do ensino francês da Beaux Arts, aliado à instrução científica da Escola de Engenharia, onde parte das disciplinas do curso

\footnotetext{
${ }^{17}$ No trabalho de Azevedo (1998), a autora bem destaca o fato do professor Christiano ter projetado o primeiro arranha-céu de São Paulo. Nesta pesquisa, não foi possível estabelecer relações quanto à este fato e a formação dos alunos da escola, ou em que medida o tema era tratado nas disciplinas do curso da Mackenzie, sendo ainda, um estudo em potencial.
} 
de engenharia civil eram dadas também no curso de engenheiro-arquiteto. (STOCKLER; BREIA, 2005)

O curso realizava concursos internos, exposições dos trabalhos realizados pelos alunos, eram incentivados estágios no escritórios existentes e a experiência no canteiro de obras através de visitas em edifícios em execução. $O$ título de engenheiro-arquiteto permaneceu até 1947, quando o curso foi desmembrado totalmente da Escola de Engenharia, constituindo-se a Faculdade de Arquitetura da Universidade Mackenzie. (STOCKLER; BREIA, 2005)

Através do trabalho de STOCKLER e BREIA (2005), foi observado que a arquitetura moderna era combatida de forma ferrenha pelo professor Christiano S. das Neves, diretor da escola por muitos anos. Somente a partir de meados da década de 1950, a arquitetura moderna pôde ser lentamente incluída no curso, não somente pela aposentadora de Christiano que data desse mesmo período, mas também pela conjuntura da produção arquitetônica brasileira, que naquele momento já evidenciava a arquitetura moderna como uma linguagem que permanecia. Sobre o pensamento do professor acerca da arquitetura moderna:

[...] A respeito do surto modernista destes últimos tempos em que a técnica construtiva e o espírito utilitário pretendem fazer desaparecer a maior das artes do desenho, fruto do materialismo da presente época, talvez produto da moda, que é efêmera, a Faculdade de Arquitetura, tem procurado conciliar aquêle aspecto acessório da Arquitetura, com os princípios que vêm regendo a grande arte durante milênios.

E isto porque, conforme muito bem disse Alexis Carrel, a sociedade é constituída de vivos e mortos e, portanto, dos ensinamentos e experiências dos nossos antepassados onde não se pode fazer tábula raza, conforme pretendem os modernistas na sua proscrição ao belo, ou seja, pura demonstração materialista, revolucionária, excêntrica. 
Nossos alunos são, pois aconselhados a não se excederem nessas tendências, aliás, passageiras, em todos os movimentos essa natureza, "maximé", quando se afastam da tradição e dos princípios instáveis do belo, que é eterno.

O ensino da arquitetura não pode estar a mercê da moda do momento, isto é, da preferência por esta ou aquela corrente artística, principalmente nos dias presentes, em que a técnica construtiva pessoal, que é um meio, pretenda suplantar a Arquitetura, que é, um fim. (REVISTA DE ENGENHARIA MACKENZIE, 1952 apud STOCKLER; BREIA, 2005, pp. 182-183)

STOCKLER e BREIA (2005) conta que a não abordagem do tema na escola causava certa rebelião entre os alunos, que entravam em contato com a arquitetura moderna por outros meios, através de revistas estrangeiras, conversas com alunos de outras escolas e rodas de discussão fora da Mackenzie, onde é importante lembrar a proximidade dessa universidade com a Faculdade de Arquitetura e Urbanismo da Universidade de São Paulo (FAUUSP), à época, situada na rua Maranhão.

Enquanto concepção projetual, a arquitetura moderna não fez parte da formação acadêmica de Germano Gultzgoff e Paulo de Freitas, formados respectivamente, em 1950 e 1955 pela Faculdade de Arquitetura Mackenzie. Pelo menos, não por meio das disciplinas ministradas durante o curso. O período em que Gultzgoff trabalhou com Bratke e que Paulo de Freitas trabalhou com Franz Heep certamente foi substancial na formação profissional desses arquitetos e no contato destes com a arquitetura moderna. Paulo de Freitas foi um desses alunos, frequentadores de rodas de bate papo, onde cita a participação de Vilanova Artigas e Eduardo Corona, arquitetos reconhecidos no ensino e discussão acerca da nova arquitetura brasileira. Pouco mais tarde, Corona passou a dar aulas na Faculdade de Arquitetura Mackenzie, tornando-se professor catedrático da escola em 1957. Seria uma pesquisa em potencial a que 
se interessasse pela relação entre a formação acadêmica desses profissionais e o conjunto da obra de cada arquiteto, o que nesse trabalho, ainda não foi possível discorrer com consistência.

Outras pesquisas que partem da difusão do moderno no interior do Brasil têm demonstrado que há uma correspondência no que diz respeito à produção de uma arquitetura moderna junto ao despertar dessas cidades para a verticalização nos anos de 1960. Assim como no Triângulo Mineiro e Alto Paranaíba, o reconhecimento da arquitetura moderna pela população local, através da construção de Brasília, recorre no interior brasileiro como um fator substancial para a difusão do moderno. Os prédios altos e os conjuntos habitacionais de arquitetura moderna eram divulgados, agora, por meio da comunicação de massa, e as novas possibilidades construtivas que chegavam no Triângulo Mineiro possibilitavam a confluência da nova tipologia à arquitetura moderna, a qual era gradativamente abraçada pela população à medida que esta a reconhecia como linguagem escolhida pelo governo nacional. 


\section{A Vila de Operadores de Jaguara: o Alcance da Arquitetura Moderna nas Pequenas Cidades}

A Vila de Operadores de Jaguara hoje forma o Parque Náutico de Jaguara, situado às margens do Rio Grande, no município de Sacramento, Minas Gerais. A vila foi construída em finais da década de 1960 pela Companhia Energética de Minas Gerais - CEMIG, com objetivo de acomodar os operários da Usina Hidrelétrica de Jaguara. Situada na microrregião de Araxá, que no ano de 1970 tinha cerca de 35 mil habitantes. A antiga vila de operadores, em seu conjunto, é a obra moderna de maior porte encontrada no Triângulo Mineiro e Alto Paranaíba.

No Brasil, a partir, sobretudo, da segunda metade do século XIX, difundiu-se largamente a prática de construção de moradias operárias por empresas de diversos setores, como uma alternativa segura de investimento ${ }^{18}$. Localizadas em núcleos urbanos ou no campo, essas moradias funcionavam como atrativo para a mão-de-obra operária, ao aproximá-la do local de trabalho.

Dentro da produção rentista - modo dominante de morar até a década de 1930 - a vila operária constituía-se na forma de pequenas moradias unifamiliares construídas em série. A moradia unifamiliar era a modalidade vista pelos higienistas, assim como para o poder público, como a melhor e mais salubre forma de habitação operária, ainda que, no começo do século XIX, à esse tipo de moradia, somente a parcela de trabalhadores mais qualificados tivesse acesso. (BONDUKI, 1998)

Tal tipo de assentamento habitacional promovido por empresas, criavam não só vilas mas verdadeiras cidadelas uma vez que se estabeleciam em locais isolados, onde inexistia mercado de trabalho ou cidades capazes de concentrar

\footnotetext{
${ }^{18} \mathrm{O}$ valor investido pelas empresas na construção das vilas era irrisório face os investimentos em maquinarias, matéria-prima, energia, administração, etc. Por outro lado, o lucro gerado pela cobrança dos alugueis se tornava capital constante da empresa ao passo que o aluguel reduzia o salário do empregador e uma vez que o investimento nas habitações poderia jamais ser renovado pelo empresário. (BLAY, 1985)
} 
trabalhadores e oferecer o mínimo de serviços e equipamentos urbanos. Como cidadelas, essas vilas contavam com vários equipamentos coletivos como escolas, igrejas, enfermarias, clubes, comércio, etc. A partir do crescimento desses pequenos núcleos urbanos, que iam se integrando ao perímetro urbano das cidades, foram originados diversos bairros, como alguns na cidade de São Paulo. (BONDUKI, 1998)

Entre 1880 e 1930, alguns exemplares desse tipo de moradia surgem com uma arquitetura inspirada em modelos tradicionais brasileiros, como as casas com portas e janelas dispostas em renque, desprovidas de recuos frontais ou laterais, e por vezes apresentando alpendres frontais. A partir do final do século XIX, algumas inovações trazidas pelos higienistas vão se fazendo presentes, como a disposição da unidade residencial no lote, já com recuos laterais. Outras características formais remetiam a modelos europeus, incluindo ornamentos, mas em geral, assumiam formas mais despojadas, expressando tipicamente uma paisagem industrial, como o uso, por exemplo, do tijolo aparente, sem ornatos, presando uma simplificação formal. Correia (2010) aponta que, em um primeiro momento, essa arquitetura afirmava-se como "importante expressão da era industrial, não apenas por suas origens, usos, funções e conflitos sociais, como também por suas características formais, que usualmente remetem à valores, materiais e símbolos do mundo fabril."

Com a construção em grande escala de vilas operárias nas décadas de 1930, 1940 e 1950, aparece uma vertente moderna nesse tipo de moradia, dando-se primeiramente dentro de uma estética ainda art-déco. Correia, Ghoubar e Mautner (2006) comentam que, a partir da segunda metade da década de 1930, a construção desses núcleos foi caracterizada por uma crescente participação de arquitetos e urbanistas, onde os projetos eram elaborados pelos mais destacados arquitetos atuantes do século XX. A presença desses profissionais introduzia transformações no formato das vilas operárias, 
principalmente dado os compromissos profissionais e éticos com a qualidade do projeto e com o bem-estar dos usuários, uma premissa moderna.

A Vila de Operadores de Jaguara ${ }^{19}$ foi construída a partir da implantação da Usina Hidrelétrica de Jaguara pela empresa CEMIG (Companhia Energética de Minas Gerais), entre os anos de 1966 e 1972, na Bacia do Rio Grande ${ }^{20}$. A vila apresenta uma concepção de projeto moderna. Os edifícios que a integram apresentam elementos fartamente usados na arquitetura moderna brasileira, como cobogós, revestimentos em pedras finas, o tijolo cerâmico aparente, e em outros casos deixando a vista a textura do concreto. Nas plantas coletadas pelo NUTHAU-FAUeD / UFU, nota-se o desenho minucioso para os detalhes singulares de esquadrias, escadas, coberturas, dentro de um projeto executivo de alto nível, onde também foram percebidas soluções apuradas no que diz respeito à funcionalidade de cada programa.

Instalada em uma área de 250 hectares, localizada na rodovia MG-428, km102, cerca de $20 \mathrm{~km}$ do núcleo urbano de Sacramento e $5 \mathrm{~km}$ da cidade paulista de Rifaina, a Usina Hidrelétrica de Jaguara foi construída com recursos próprios da CEMIG e do Governo de Minas Gerais e financiamentos do Banco Mundial e da Eletrobrás.

Suas obras foram iniciadas em julho de 1966 e a conclusão da primeira etapa ocorreu em novembro de 1971, sendo inaugurada no ano seguinte. Seu objetivo era abastecer diretamente as regiões do Triângulo Mineiro e Alto Paranaíba e indiretamente a região central de Minas, ao redor de Belo Horizonte, e dali irradiar energia para o resto do estado. Esses empreendimentos,

\footnotetext{
${ }^{19}$ Crozara e Cappello (2011) comentam que a denominação "vilas dos operadores" especifica vilas vinculadas a usinas hidrelétricas, expressando também o caráter privado desses complexos, excluindo nomenclaturas que indicam propostas próximas a de uma cidade, uma vez que o porte dessas vilas é pequeno para ser comparado à complexidade das relações que existem no núcleo urbano de uma cidade.

${ }^{20}$ Segundo Guerra (2008), as bacias do Rio Grande e do Rio Paranaíba foram consideradas um espaço estratégico e de forte potencial de energia para investimentos destinados à infra-estrutura energética. Esses investimentos fizeram parte de um contexto político, entre 1960 e 1970, caracterizado pela implantação de planos de desenvolvimento nos diversos setores da vida nacional, como o setor de produção e distribuição de energia elétrica. Neste contexto surgiram a maioria das vilas de operadores de usinas hidrelétricas na região do Triângulo Mineiro e arredores.
} 
localizados em regiões remotas - destacando que a usina de Jaguara foi construída fora do perímetro urbano de Sacramento - com redes urbanas e viárias insipientes, também passaram a exigir a construção de núcleos que oferecessem aos operários e, posteriormente, às suas famílias, moradia e outros serviços públicos necessários.

Nas plantas dos projetos para a Vila de Operadores de Jaguara, a pesquisa do NUTHAU-FAUeD / UFU descobriu que a obra esteve a cargo do Departamento de Engenharia Civil da CEMIG - divisão de Arquitetura e Edificações - mais colaboradores, parecendo ter sido a equipe formada mais por engenheiros civis que arquitetos. Nas plantas, foram encontrados os nomes de alguns profissionais, onde ainda não foi possível obter mais informações acerca de suas atuações, sendo eles: Maria Lacy Garcia Guimarães (arquiteta), Álvaro Pessoa Coelho (arquiteto), Cláudio Augusto Magalhães Alves (arquiteto), Reynaldo Luiz Calvo (arquiteto e presidente do IAB no período 1970/1971), Isvaú, Wilda e Luis. (CROZARA; CAPPELLO, 2011)

Vista essa relação de profissionais encontrada nas plantas dos projetos, perde-se em nossa linha histórica da produção arquitetônica moderna do Triângulo Mineiro e Alto Paranaíba, a relação de autoria que vínhamos fazendo até então nesse trabalho. Ou seja, a relação direta entre autor-obra. A Vila de Operadores de Jaguara nos mostra um momento de uma arquitetura corporativa ao invés daquela individualizada que mostramos na relação de obras escolhidas nesse trabalho.

As datas dos projetos também não são precisas. O plano urbano nas plantas data de 1965 e os demais projetos dos equipamentos urbanos variam entre 1965 a 1968, mas sabe-se que a construção da vila ocorreu concomitantemente à construção da usina, inaugurada em 1971. Ainda, há relatos de ex-funcionários acerca da existência de um acampamento temporário 
de aproximadamente 30 casas nas proximidades da usina, posteriormente demolidas. (CROZARA; CAPPELLO, 2011)

A vila possui 70 casas em lotes de $1.400 \mathrm{~m}^{2}$, hotel abastecido de restaurante, clube esportivo, um templo ecumênico, posto de saúde, casa de visitas, centro comercial, escola, administração, lavanderia, campo de futebol e outras quadras esportivas, uma pista de pouso asfaltada com 1.100 metros lineares, equipada com uma pequena estação de passageiros e guarita.

Implantada em uma topografia relativamente plana, linear às margens do Rio Grande, o plano para a vila seguia uma estrutura "espinha de peixe", caracterizada por um eixo central, correspondente a Avenida Rio Grande, principal via da vila, da qual surgiam as vias secundárias, essas ultimas destinadas ao acesso das residências e equipamentos públicos.

Cada equipamento foi estrategicamente posicionado no plano. A Escola, o Centro Comercial e a Administração, como mais usados, concentraram-se centralmente no traçado. O Hotel e a Casa de Visitas, aproximados das margens do rio e afastados das quadras residenciais, exprimiam sua relevância por meio do isolamento. O templo, situado ao fim da Avenida Rio Grande, pode ser visto por todo o caminho percorrido dentro da vila, exprimindo o caráter simbólico desse edifício. 


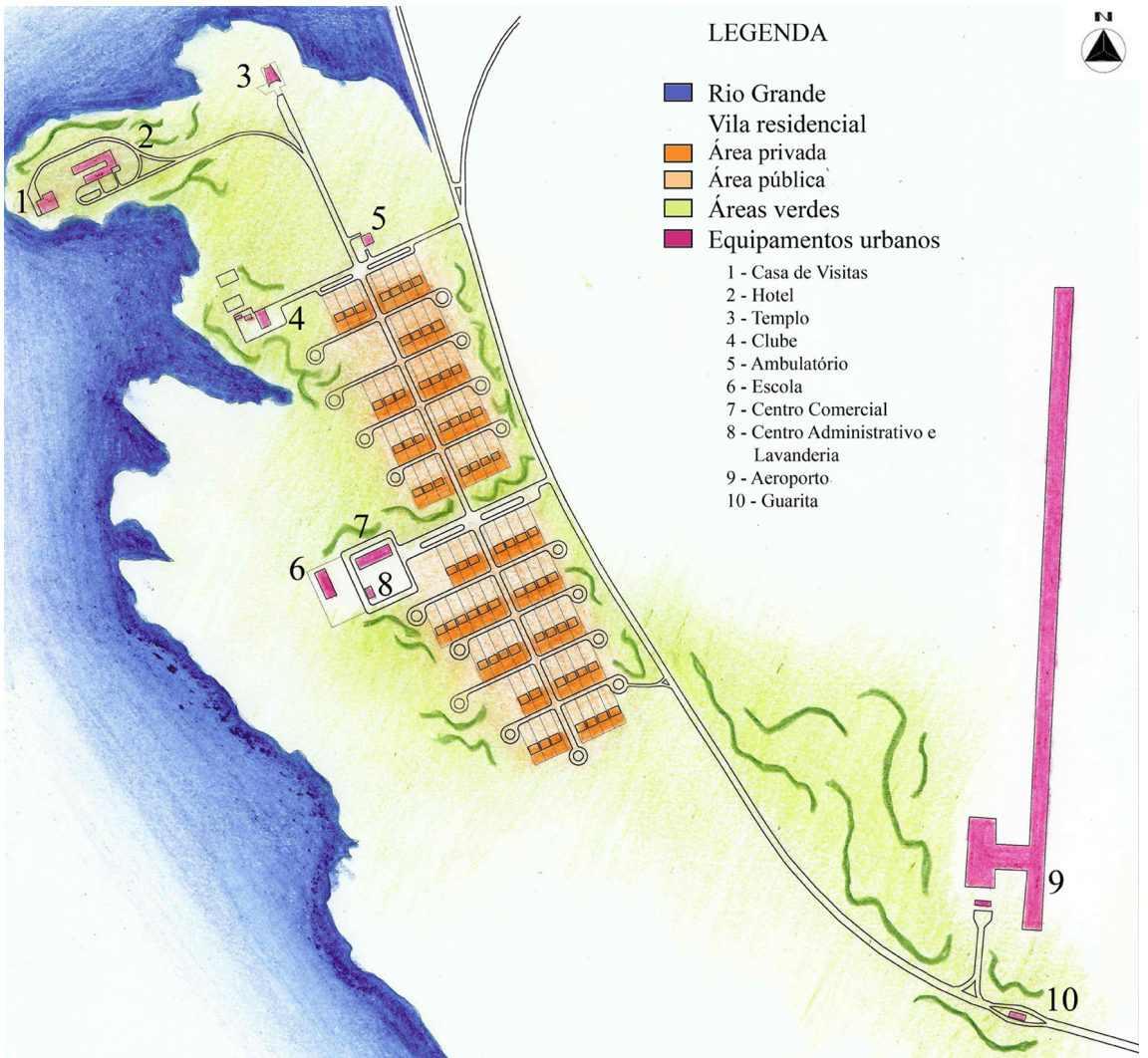

124. Vila de Operadores de Jaguara . Setorização. Fonte: CROZARA;CAPPELLO, 2011 NUTHAU-FAUED / UFU.

125. Vila de Operadores de Jaguara. Foto Aérea. Fonte: Google Maps, 2009 NUTHAU-FAUeD / UFU.

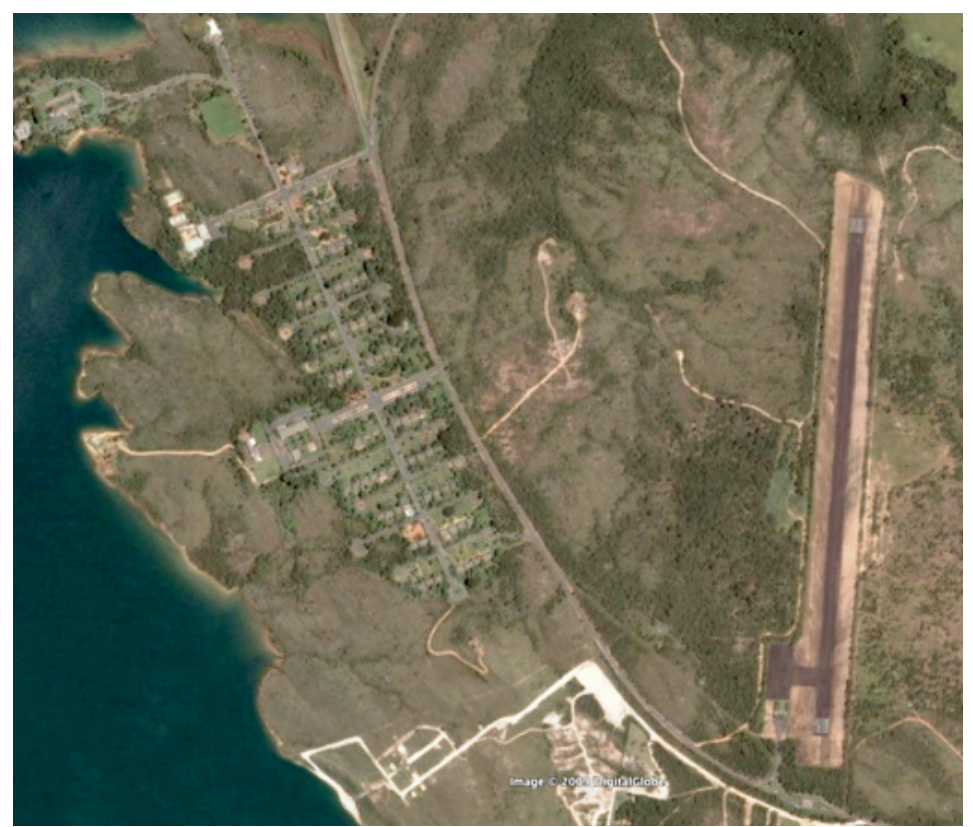


126. Vila de Operadores de Jaguara. Av. Rio Grande. Fonte: NUTHAU-FAUeD / UFU.

127. Vila de Operadores de Jaguara. Av. Três Marias. Fonte: NUTHAU-FAUED / UFU.

128. Vila de Operadores de Jaguara. Cul-de-Sac. Fonte: NUTHAU-FAUED / UFU.
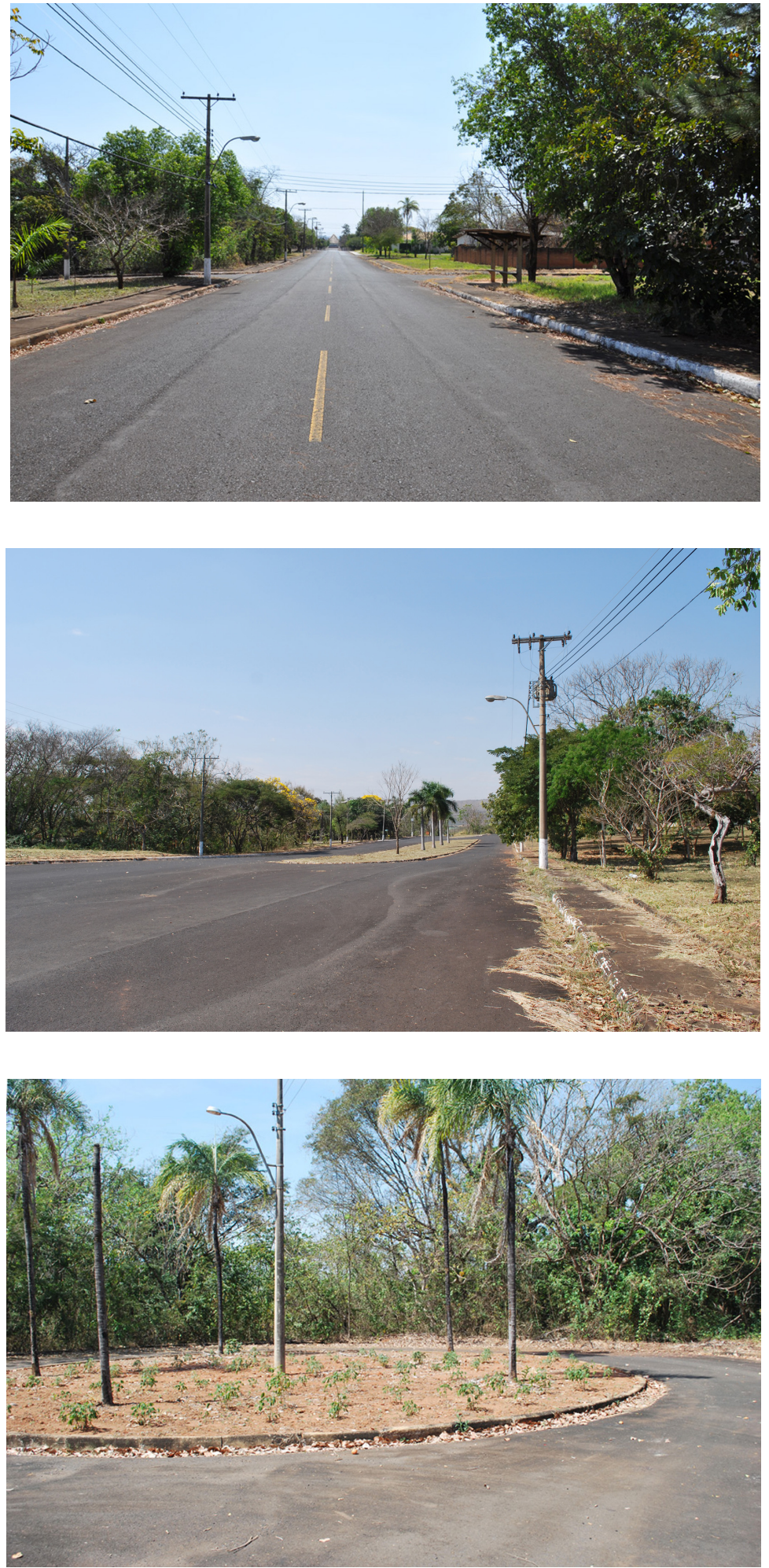
O loteamento onde as residências estão implantadas possui forma retangular, de $1400 \mathrm{~m}^{2}$ cada, de grande profundidade, atravessando todo o quarteirão. Dessa forma, ao atravessarmos uma das vias secundárias, enxergamos, de um lado, a frente de uma residência, e do outro lado da via, os fundos de uma outra residência. A implantação das casas se dá de forma central no lote, onde há um grande afastamento frontal, o que permitiu um espaço maior para a elaboração de jardins e espaços coletivos antecedendo o acesso social de cada residência, uma vez que estas áreas não estão delimitadas para cada lote, ao contrário, dos fundos do lote, onde se configurou uma área de lazer privada para cada família.

As 70 unidades residenciais da vila seguem o mesmo tipo de implantação e técnicas construtivas. As diferenças entre os quatro tipos de habitação estão na articulação da planta, na área construída e nos detalhes da fachada frontal. Todos os quatro tipos de plantas são retangulares, com programa contendo: sala, cozinha, três ou quatro quartos, as vezes uma suíte e um outro cômodo chamado "quarto reversível", e um banheiro. Há também uma varanda frontal, que precede o acesso ao interior da casa, e um espaço aberto aos fundos, onde se localiza uma outra varanda com a área de serviço.

As residências foram definidas como L1, L2, L3 e L4. Desse conjunto, oito residências são do tipo $L 1$, com $53.71 \mathrm{~m}^{2}$ de área construída, trinta e oito residências são do tipo L2 com $77,43 \mathrm{~m}^{2}$ de área construída, quatro são do tipo L3 com $84.48 \mathrm{~m}^{2}$ de área construída, e vinte residências são do tipo L4 com $85,46 \mathrm{~m}^{2}$ de área construída. Crozara e Cappello (2011) sublinham o modo como as tipologias foram dispersas pelas quadras, sem originar a concentração de uma ou outra tipologia em determinado local, o que provavelmente pode ter evitado algum tipo de segregação espacial, visto que existiam operários de alto e baixo escalão morando em Jaguara. 
As residências tipo L1 possuem três quartos, cozinha e um banheiro, todos distribuídos através de uma circulação central, mais uma sala conectada à área de serviço e à varanda frontal. Essa é a única tipologia em que a sala se conecta diretamente à área de serviço, sendo que, nas outras residências, é a cozinha que faz essa conexão, integrando-se aos fundos do lote.

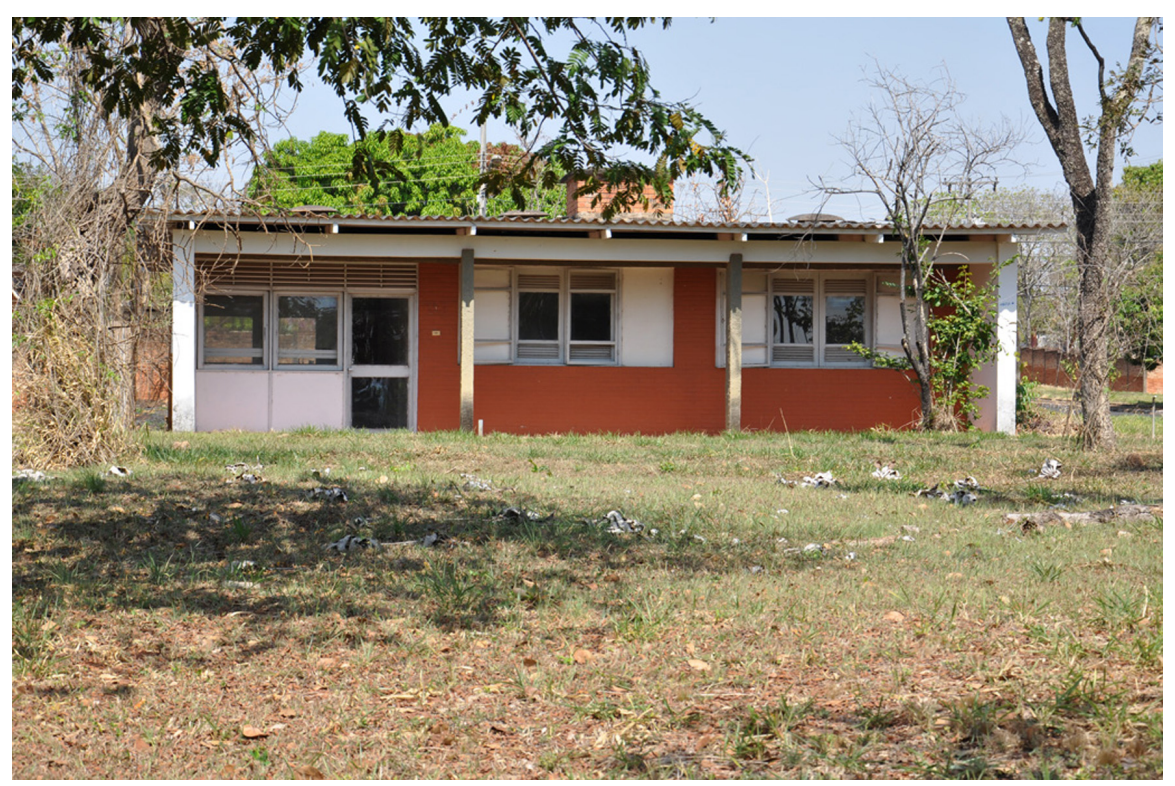

129. Vila de Operadores de Jaguara. Residência tipo L1. Fonte: NUTHAU-FAUeD / UFU.

130. Vila de Operadores de Jaguara. Residência tipo L1. Planta baixa. Fonte: NUTHAUFAUeD / UFU.

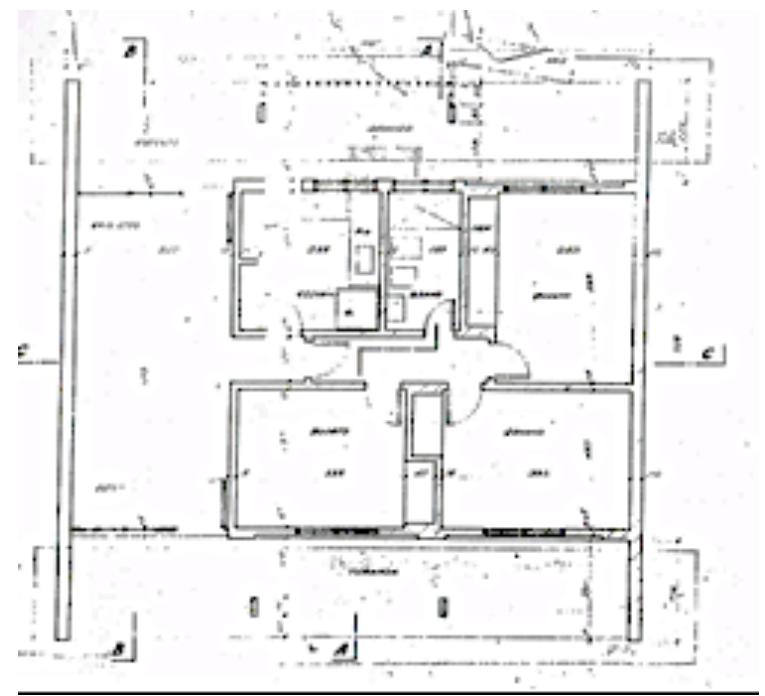


A tipologia L2 possui a mesma disposição que a L3, porém com um quarto a menos, o que fez com que sua cozinha ficasse menor na configuração da planta. Os quartos, sendo um suíte, mais o banheiro social também estão distribuídos através de um corredor central. Essa tipologia se destaca por apresentar um "quarto reversível", também encontrado na tipologia L4: um cômodo com dois acessos, um pelo interior da casa e outro pela área de serviço, podendo ser integrado à qualquer um desses espaços.

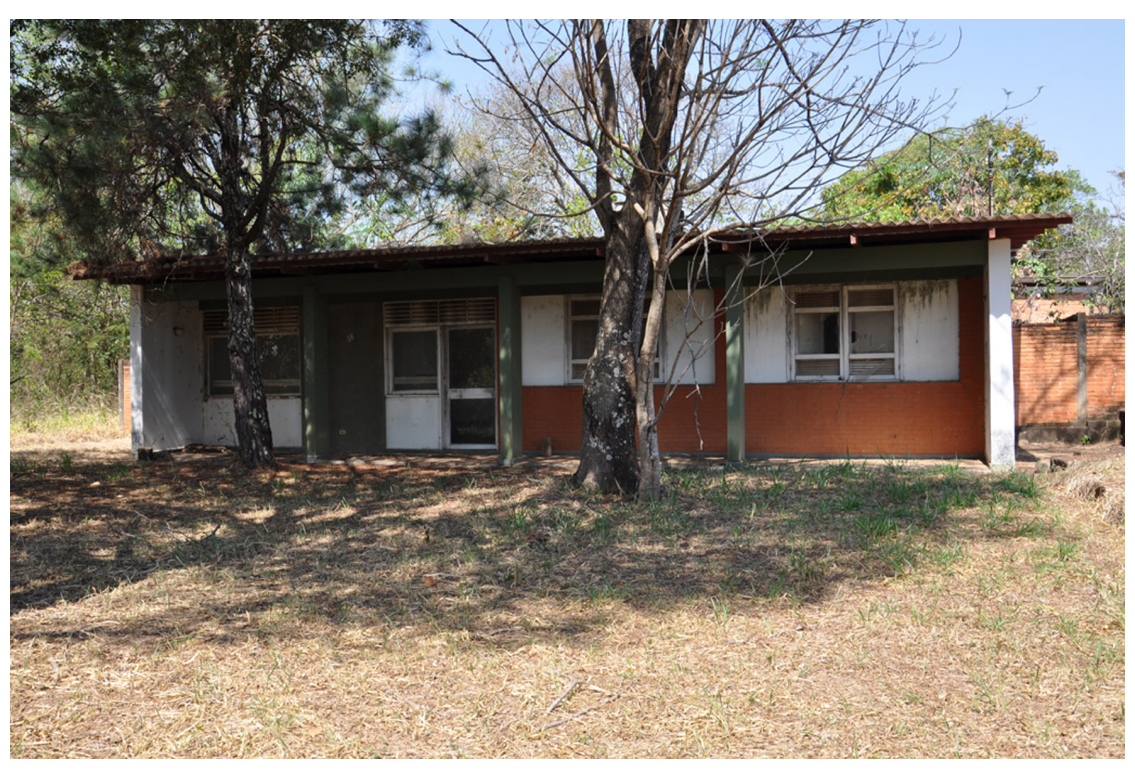

131. Vila de Operadores de Jaguara. Residência tipo L2. Fonte: NUTHAU-FAUeD / UFU.

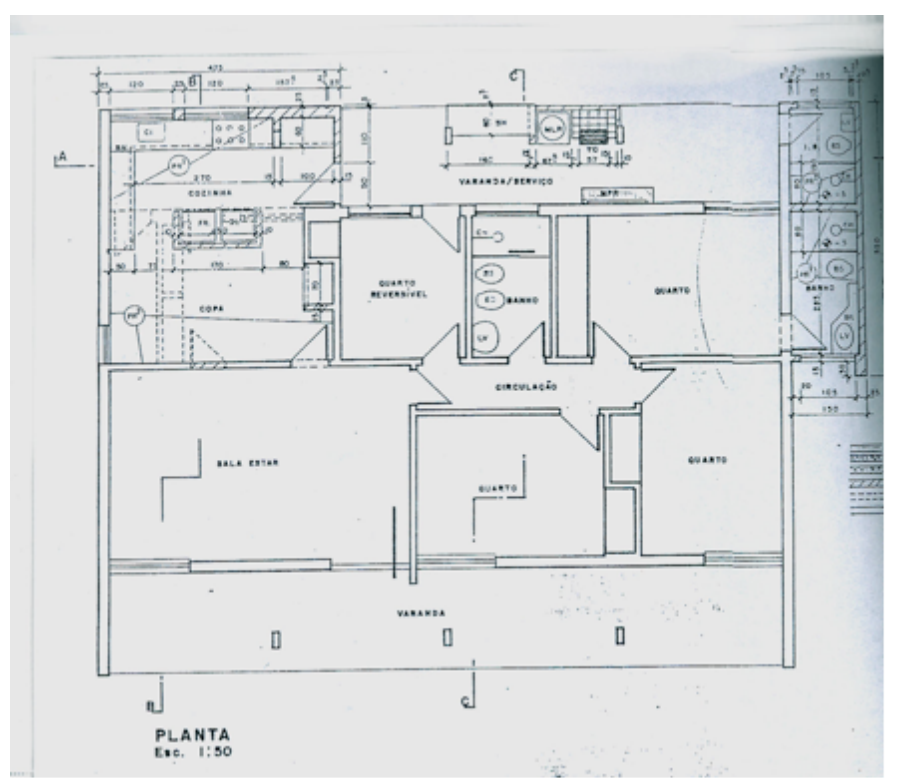

132. Vila de Operadores de Jaguara. Residência tipo L2. Planta baixa. Fonte: NUTHAU-FAUeD / UFU. 


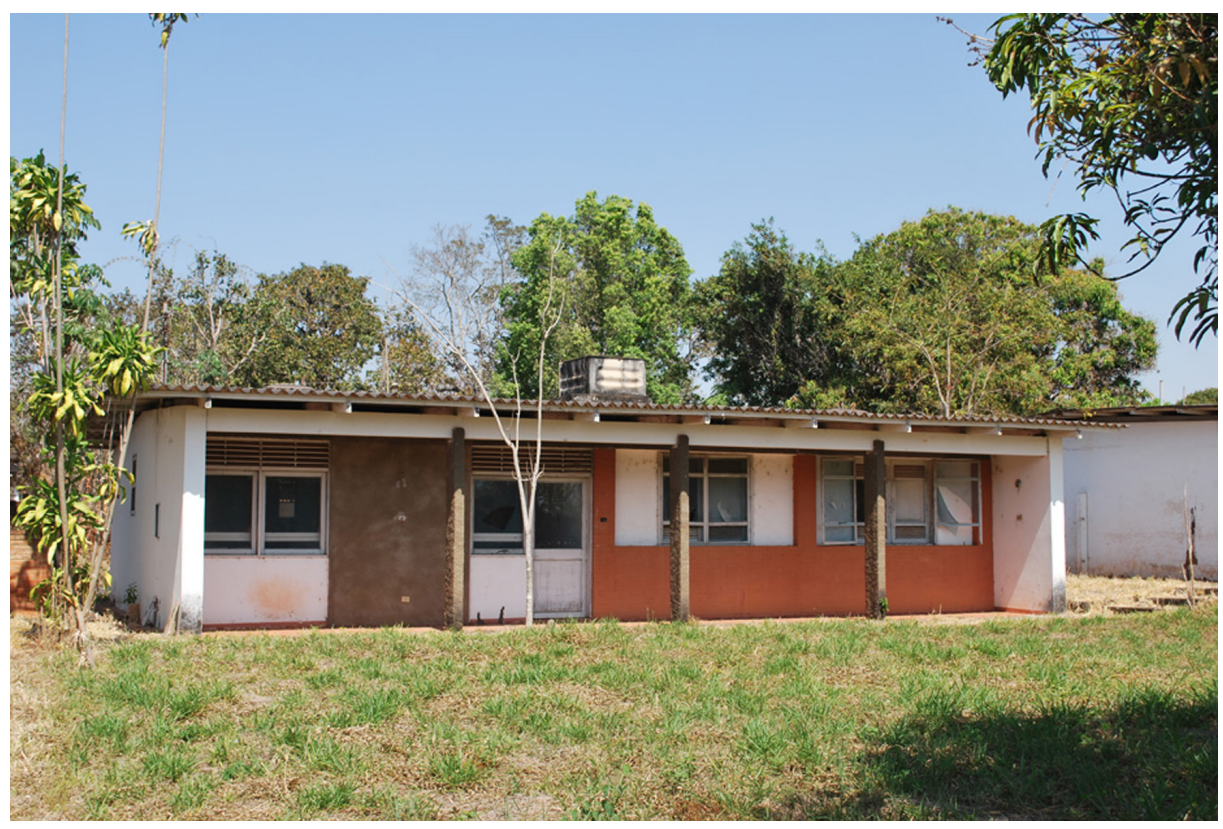

133. Vila de Operadores de Jaguara. Residência tipo L3. Fonte: NUTHAU-FAUeD / UFU.

134. Vila de Operadores de Jaguara. Residência tipo L3. Planta baixa. Fonte: NUTHAU-FAUeD / UFU.

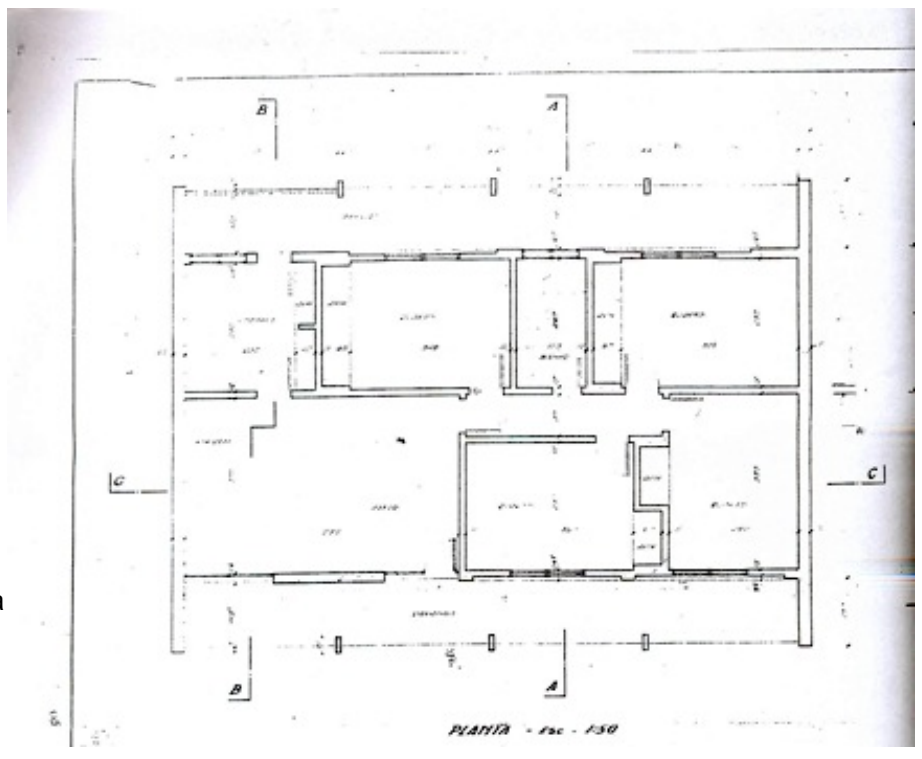

A tipologia L4, com maior área construída, possui quatro quartos, sendo um suíte, banheiro, sala e cozinha amplas, mais o quarto reversível e área de serviço aos fundos. Nela, destaca-se a configuração da cozinha, a qual também aparece na tipologia L2. Através da disposição central da despensa, o cômodo 
for organizado em duas partes: a copa, acessada pela sala, e a cozinha de fato, por onde também se chega à área de serviço.

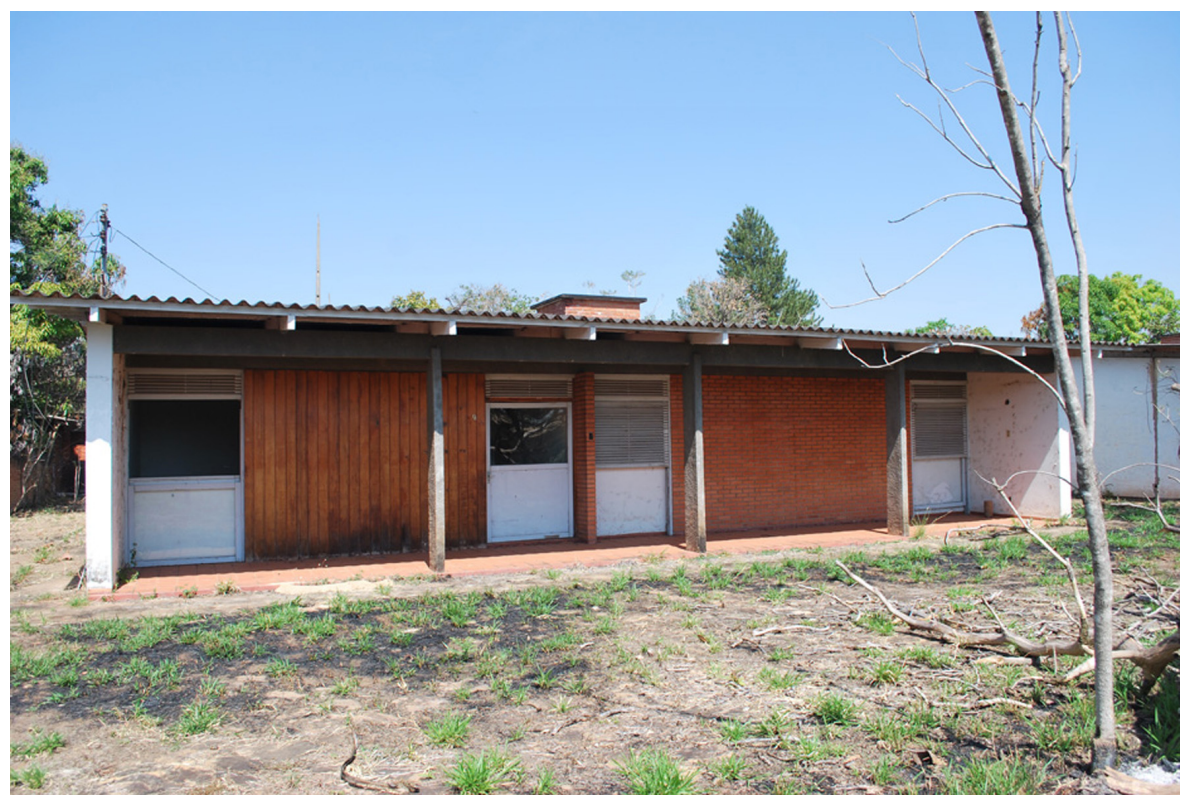

135. Vila de Operadores de Jaguara. Residência tipo L4 Fonte: NUTHAU-FAUeD / UFU.

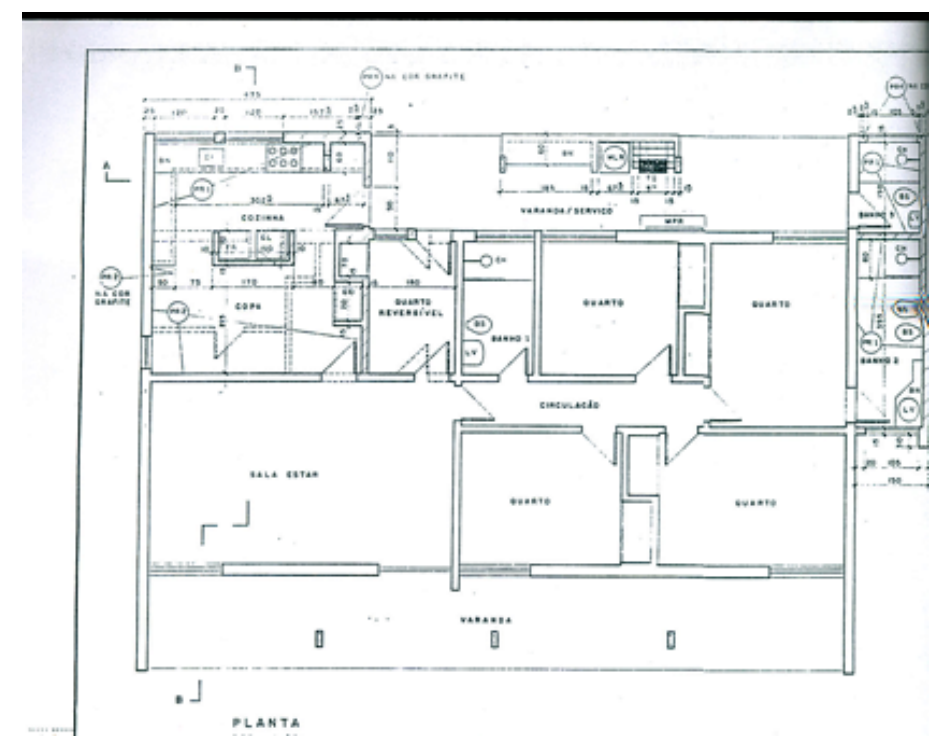

136. Vila de Operadores de Jaguara. Residência tipo L4. Planta baixa. Fonte: NUTHAU-FAUeD / UFU. 
Tirando partindo do terreno irregular em que foi implantada, a Casa de Visitas foi construída para acomodar hóspedes da diretoria e presidência da CEMIG, em estadias esporádicas na Vila de Operadores de Jaguara. Foi projetada em dois blocos integrados por um jardim central: no primeiro, de formato retangular, concentravam-se as áreas coletivas e de serviço, sendo reconhecido externamente na volumetria do edifício pela laje que repousa sobre as varandas da área de estar; no segundo, de formato em "L", foram dispostos os dormitórios que dão vista à vegetação fechada que circunda o edifício. Seu principal acesso se dá por um lance de degraus revestidos em pedra e desprovidos de corrimãos que davam acesso direto à sala de estar. Do recuo que origina o pavimento superior avarandado, é possível avistar as quadras esportivas - elaboradas para uso privativo dos hóspedes da casa - e a represa de Jaguara.

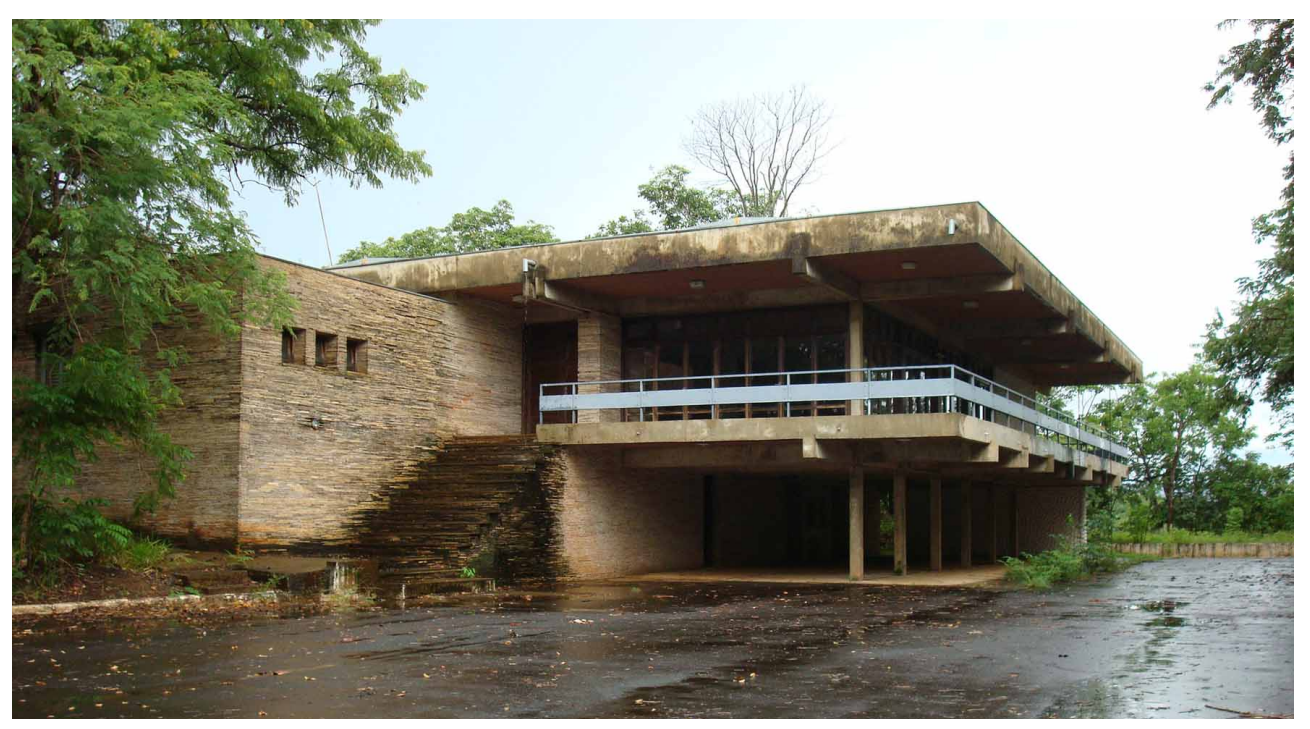

137. Vila de Operadores de Jaguara. Casa de Visitas. Fonte: NUTHAU-FAUeD / UFU. 
138. Vila de Operadores de Jaguara. Casa de Visitas. Térreo. Planta esquemática. Fonte: NUTHAU-FAUED / UFU.

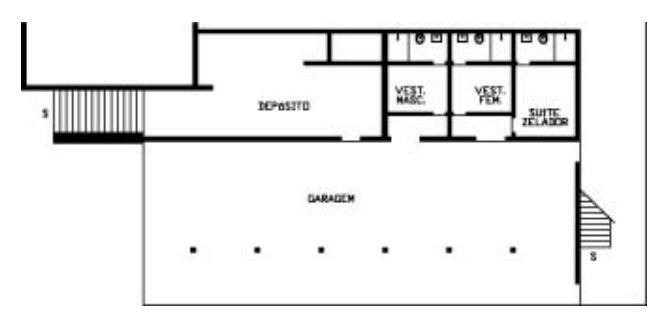

139. Vila de Operadores de Jaguara. Casa de Visitas. Pav. Superior. Planta esquemática. Fonte: NUTHAU-FAUED / UFU.
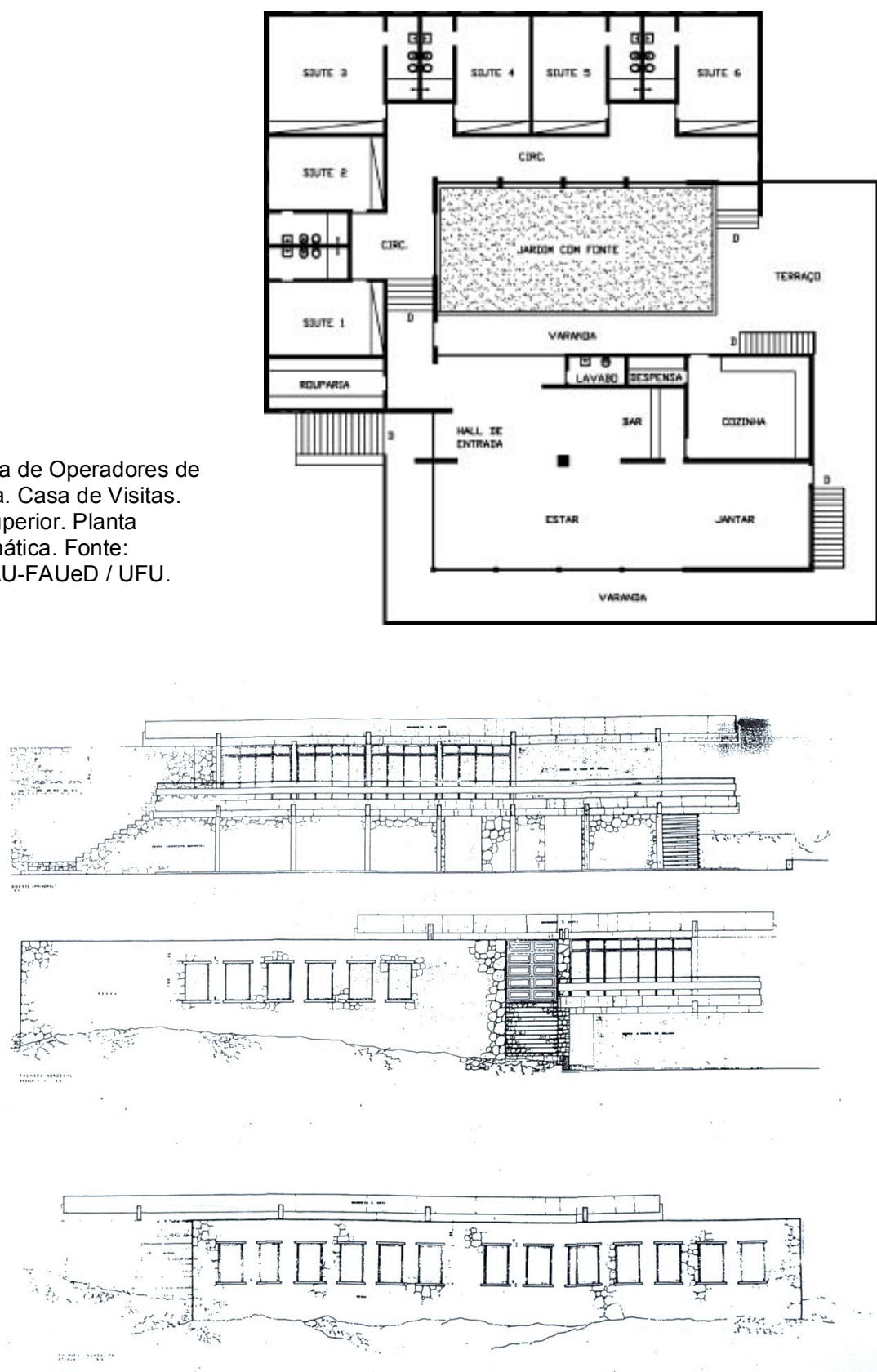

140. Vila de Operadores de Jaguara. Casa de Visitas. Elevações. Fonte: NUTHAU-FAUeD I UFU. 
O prédio para Hotel e Alojamento, localizado próximo à Casa de Visitas, foi implantado em "U" e também continha um jardim central. Este, separava o restaurante e a recepção - situados em frente a represa de Jaguara - dos alojamentos, que eram acessados por uma passarela coberta que passava pelo jardim central. Uma parede revestida de cobogós ilumina de forma difusa a circulação que distribui os alojamentos, ao todo 20 suítes. Revestimentos que mesclam pedras e tijolos cerâmicos à vista contrastam com o branco da pintura das esquadrias em madeira.

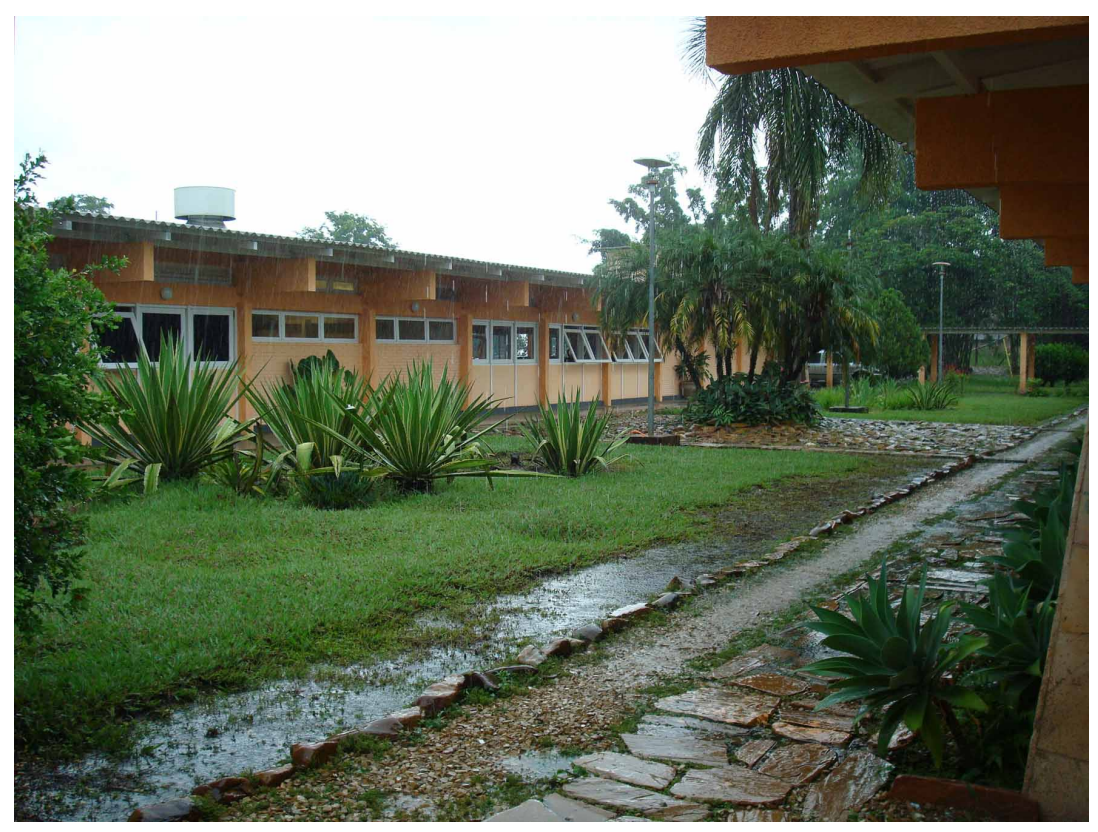

141. Vila de Operadores de Jaguara. Hotel e Alojamento. Fonte: NUTHAU-FAUeD / UFU.

142. Vila de Operadores de Jaguara. Planta esquemática. Hotel e Alojamento. Fonte: NUTHAU-FAUED / UFU.

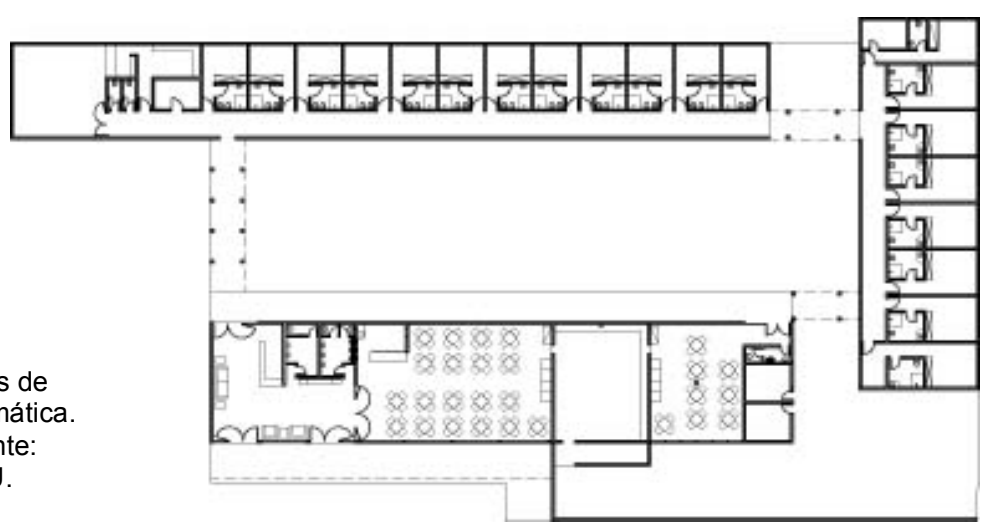


O Templo, de formato piramidal, foi proposto para abrigar em comum as diferentes religiões dos moradores da vila, foi implantado ao fim da Av. Rio Grande, principal via da Vila de Operadores de Jaguara. Tal localização permite que o templo seja avistado deste a entrada da vila e ao percorrê-la, o que foi feito com o intuito de ressaltar sua monumentalidade e simbolismo. Simbólica também é a decisão de revestir a casca externa do Templo com pintura branca e deixar o concreto das paredes do seu interior em concreto aparente. O uso da pintura branca externa exprime o caráter religioso do edifício, e no interior, o contraste com o concreto aparente, escuro, ressalta intimismo e desapego, por vezes aliviado pela luz difusa que adentra o prédio pelos rasgos trapezoidais encontrados por detrás do altar.

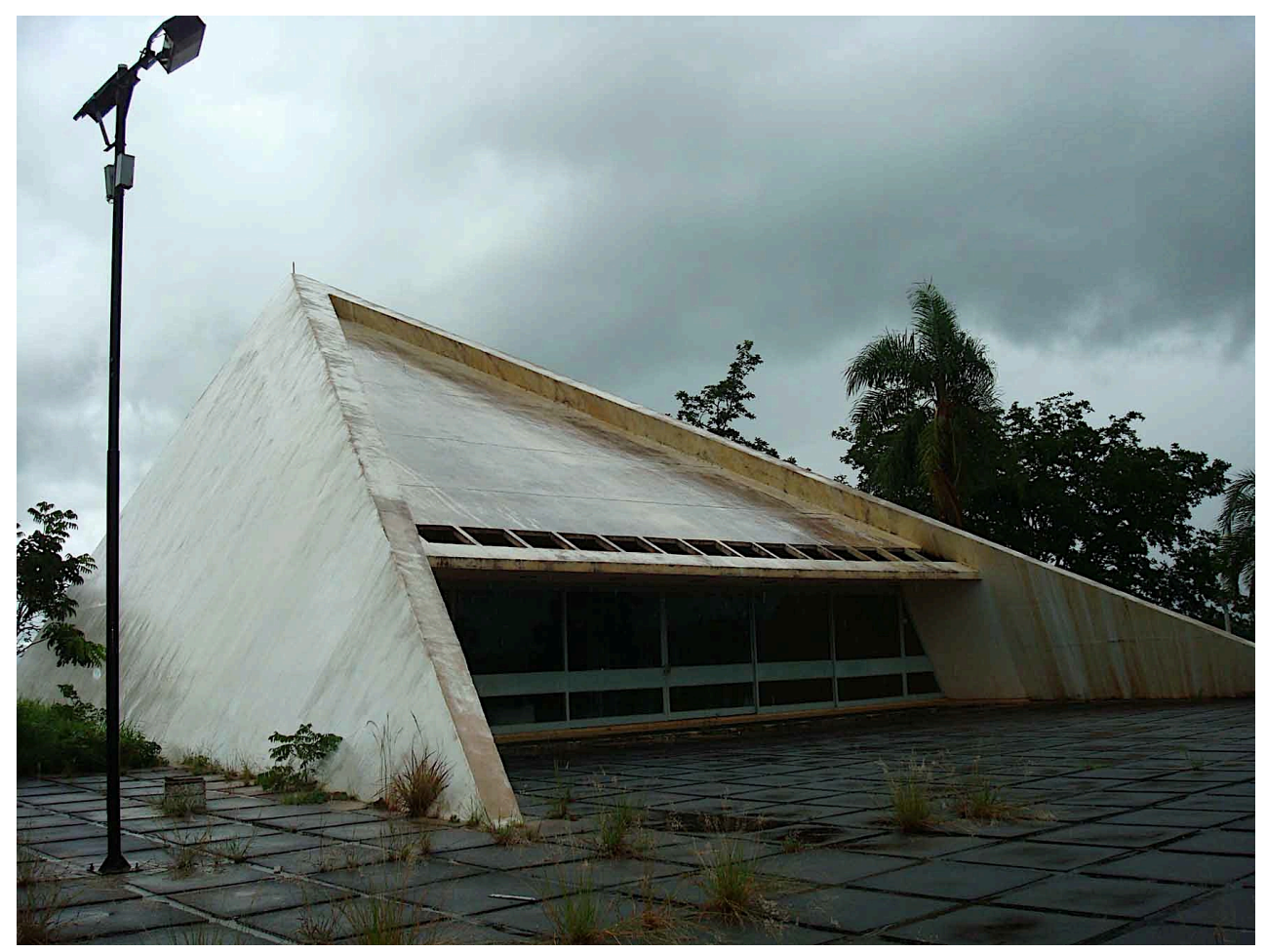

143. Vila de Operadores de Jaguara. Templo. Fonte: NUTHAU-FAUeD / UFU. 
144. Vila de Operadores de Jaguara. Templo.

Fonte: NUTHAU-FAUeD / UFU.

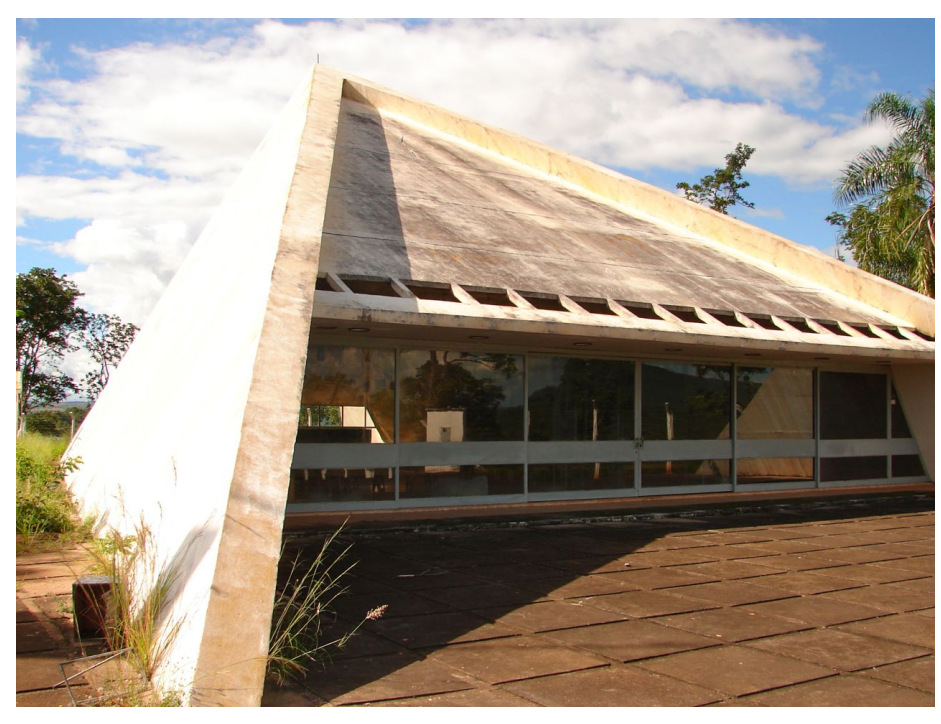

145. Vila de Operadores de Jaguara. Templo. Interior. Fonte: NUTHAU-FAUeD / UFU.

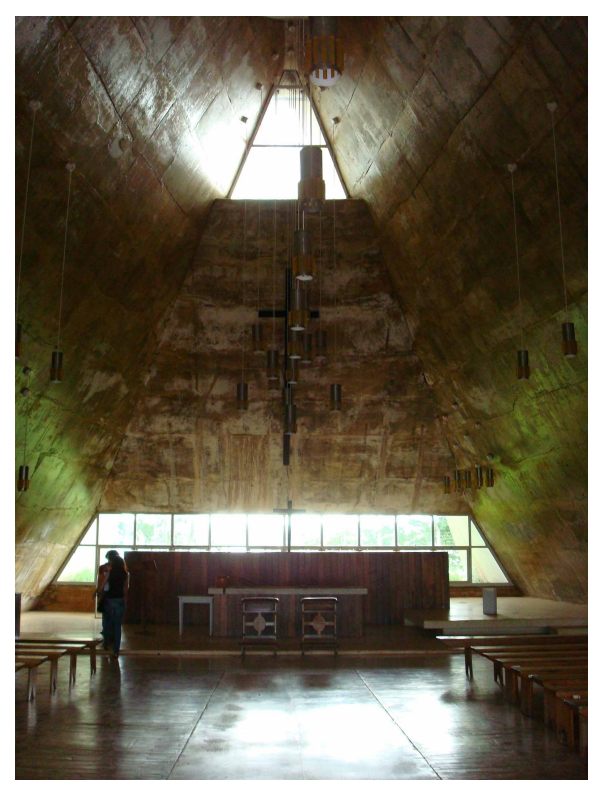

146. Vila de Operadores de Jaguara. Templo. Planta. Fonte: NUTHAUFAUeD / UFU.

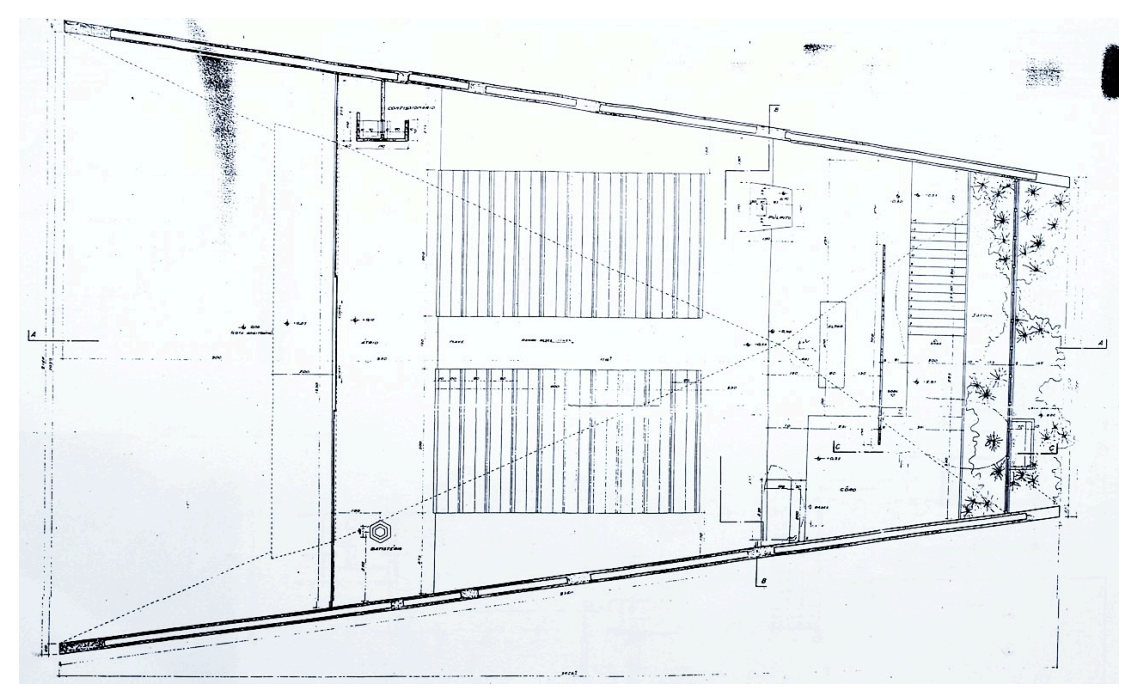


O edifício para o Clube Recreativo, destinado aos trabalhadores da CEMIG, localiza-se próximo à represa de 7.989,75 m², na Avenida Emborcação. Seu programa inclui uma piscina de $10 \times 50 \mathrm{~m}$, uma piscina infantil, salão de festas com $370 \mathrm{~m}^{2}$, bar/cozinha, duas quadras, saunas, vestiários e sala de ginástica. Na parte posterior estão as piscinas, quadras, saunas e vestiários, implantados de forma ortogonal ao bloco principal. Este, formado por três módulos, evidenciados pelas três entradas em portas de vidro, das quais duas dão acesso ao salão de jogos e uma ao salão principal.

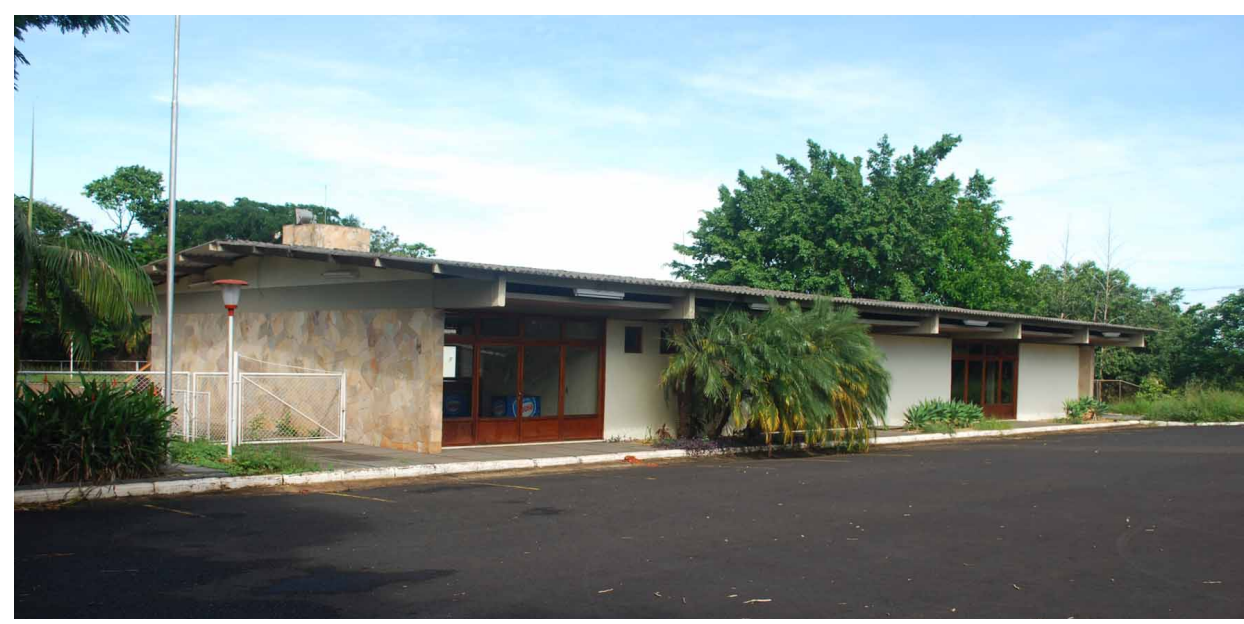

147. Vila de Operadores de Jaguara. Clube Recreativo. Fonte: NUTHAU-FAUeD / UFU.

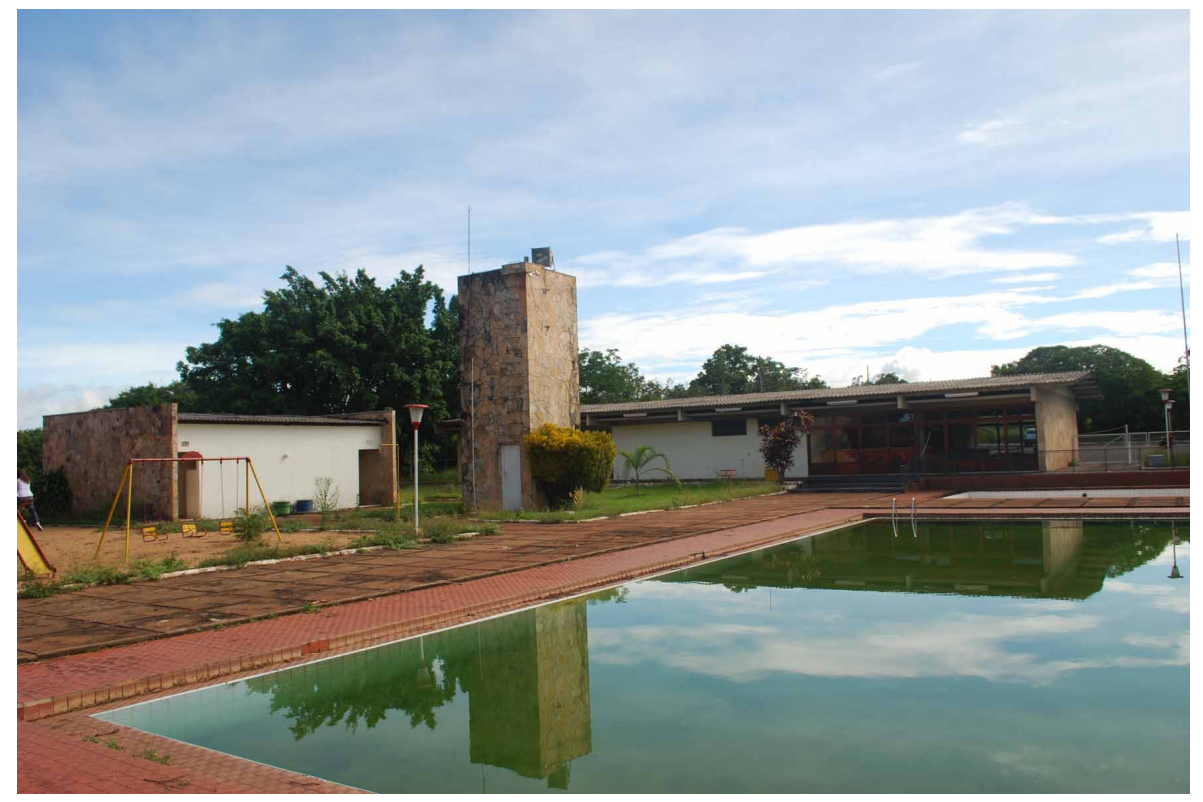

148. Vila de Operadores de Jaguara. Clube Recreativo. Equipamentos. Fonte: NUTHAU-FAUeD / UFU. 


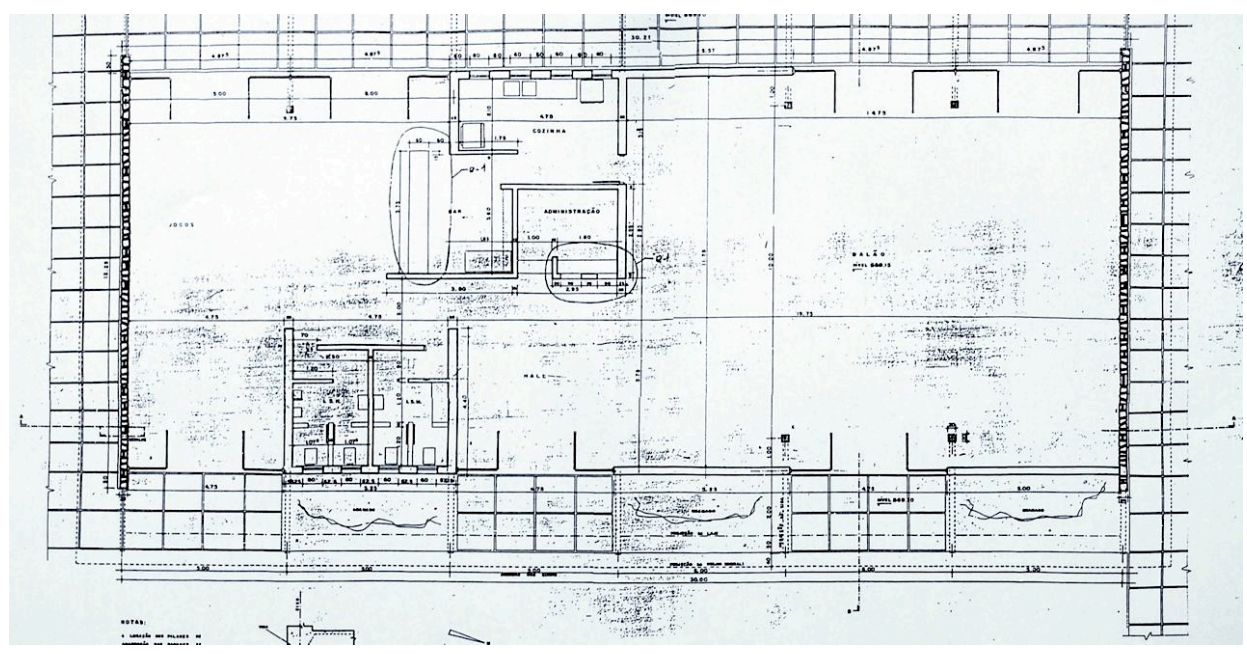

149. Vila de Operadores de Jaguara. Clube Recreativo. Planta. Fonte: NUTHAU-FAUeD / UFU.

O projeto original do prédio proposto para abrigar o Posto de Saúde da Vila dos Operadores de Jaguara se baseava na divisão de dois blocos: um maior que receberia todas as atividades referentes ao ambulatório e um bloco menor, com um programa de apoio com cozinha, copa e cantina. O projeto executado, porém, é restrito à um único bloco, com $189 \mathrm{~m}^{2}$ aproximadamente de área, no qual o programa se resume a uma sala de curativos, uma sala de observação, um consultório médico, um consultório odontológico, secretaria, vestiário e copa. Esses ambientes estão dispostos ao longo de uma circulação em "L", com acessos em cada extremidade, sendo um frontal e um lateral esquerdo. Está implantado em um lote de esquina entre as avenidas Emborcação e Rio Grande, com grandes afastamentos frontais e laterais. 


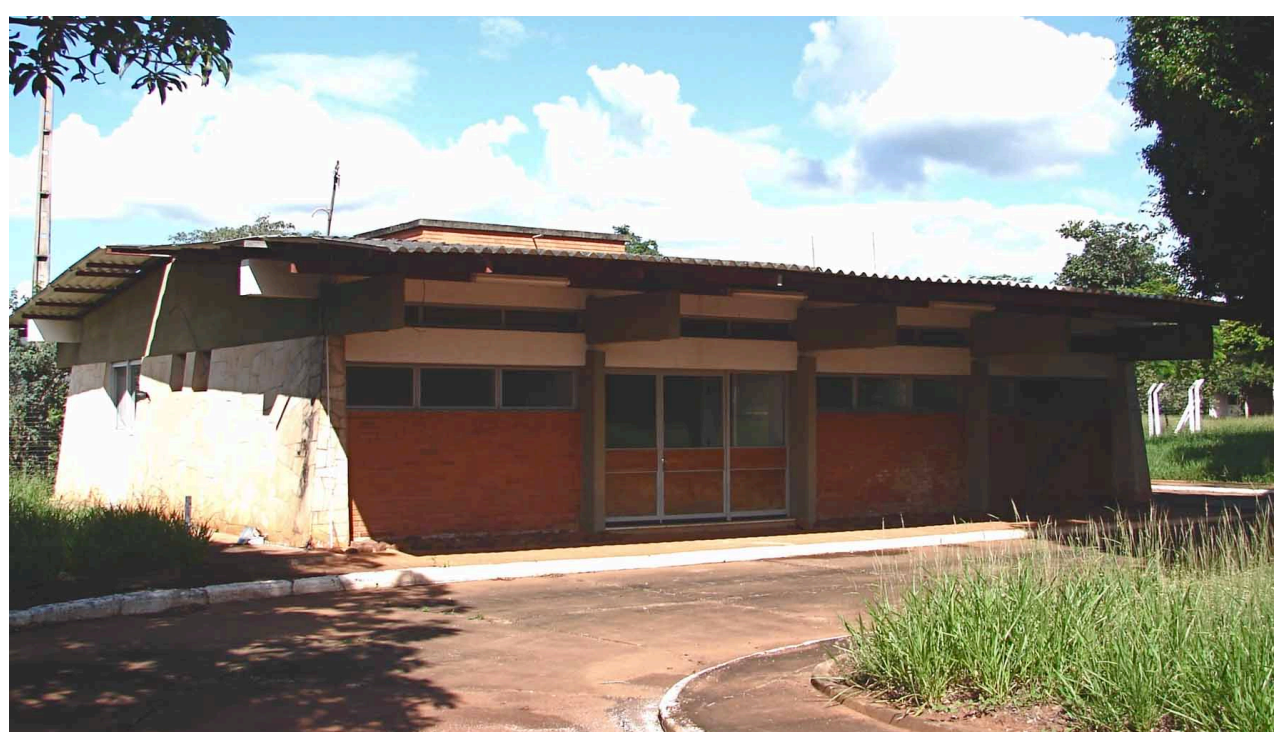

150. Vila de Operadores de Jaguara. Posto de Saúde. Fonte: NUTHAU-FAUeD / UFU.

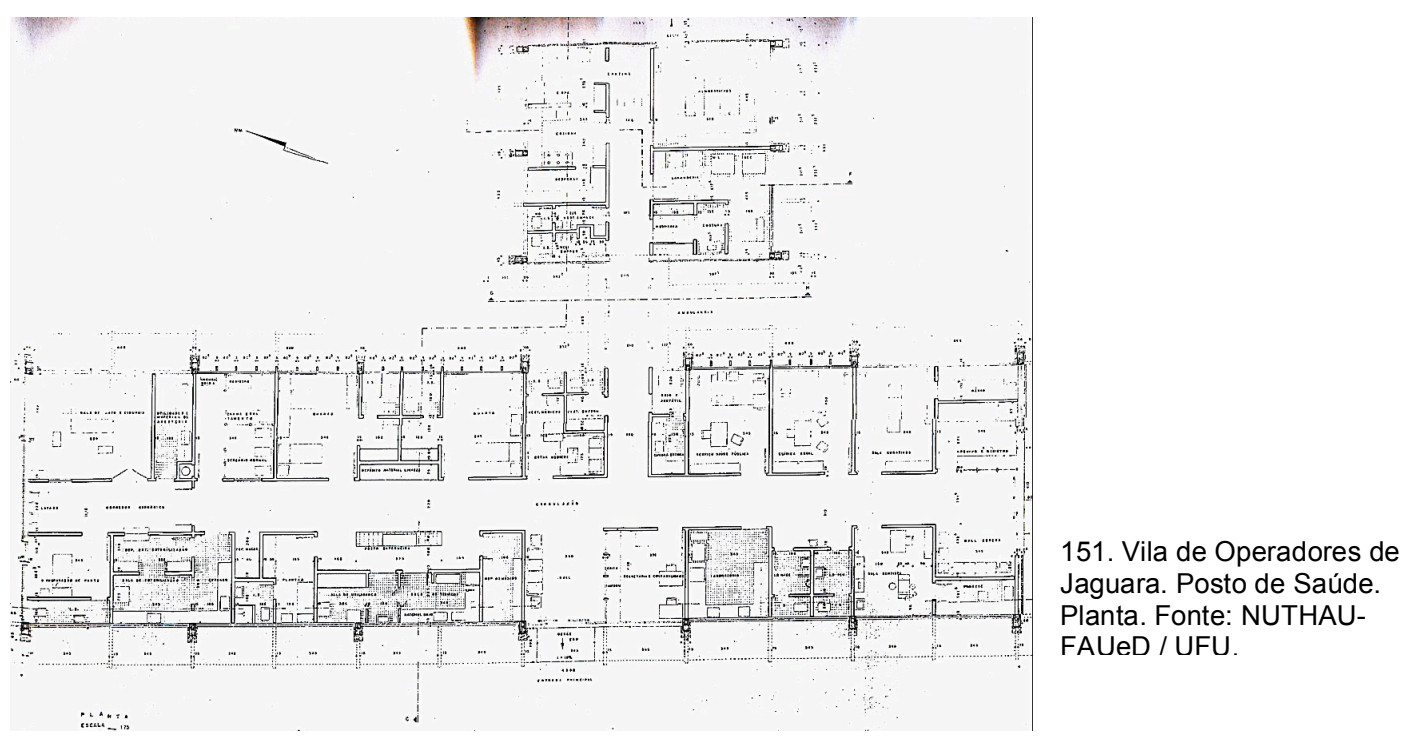

O edifício projetado para a Escola, próximo aos edifícios do Centro Comercial e da Administração/Lavanderia, encontra-se implantado em um lote plano e murado, na parte mais baixa da vila. Tal implantação é definida por um afastamento ao fundo, utilizado como área de recreação, e outro, lateral, onde se encontra a quadra de esportes. Pela entrada, chega-se à uma área aberta e um corredor, onde as salas estão dispostas lado a lado e por onde também se chega 
à um pátio coberto e à cozinha. O programa é composto de seis salas de aula, secretaria, sanitários, depósito e cozinha, totalizando uma área de $776 \mathrm{~m}^{2}$. A escola oferecia turmas até a quarta série do primeiro grau.

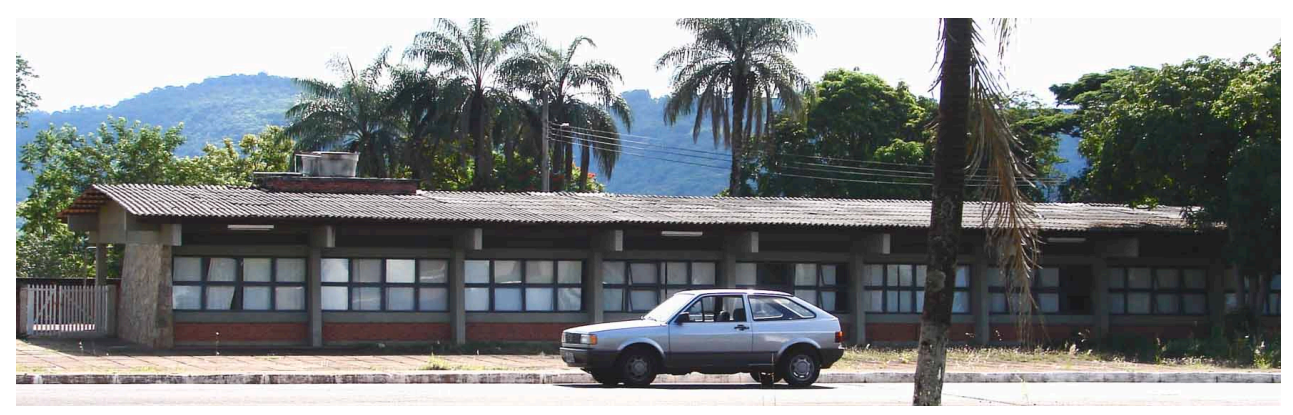

152. Vila de Operadores de Jaguara. Escola. Fonte: NUTHAU-FAUeD / UFU.

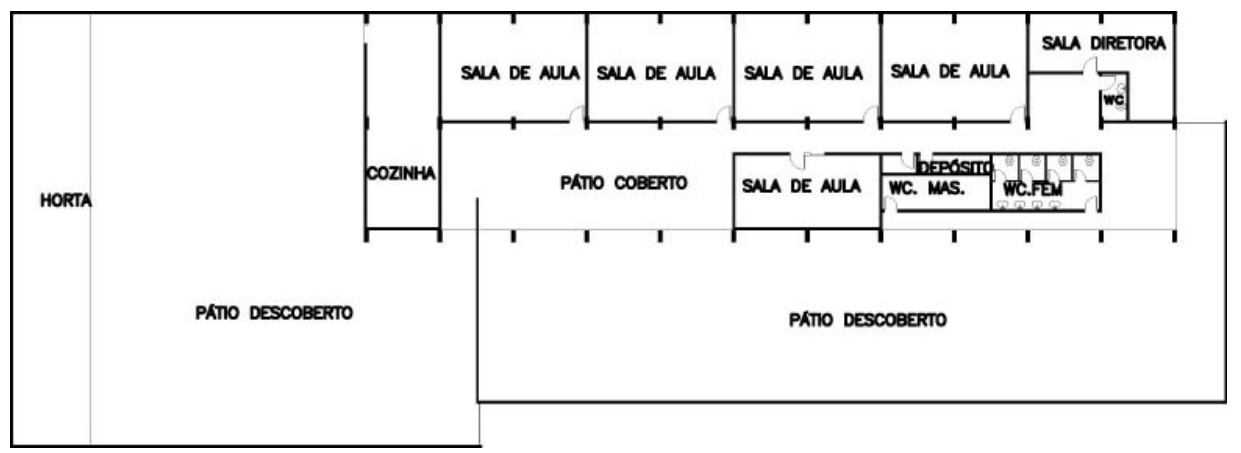

153. Vila de Operadores de Jaguara. Escola. Planta esquemática. Fonte: NUTHAU-FAUeD / UFU.

O Centro Comercial é um edifício singular na vila. Implantado em um lote plano e amplo é facilmente reconhecido por sua cobertura em "zig-zag" como se várias coberturas tipo "borboleta" tivessem sido encaixadas uma a outra. Sua concepção visava a permeabilidade do edifício, tanto visual, caracterizada pelos revestimentos em blocos de vidro e pelas esquadrias com grades pantográficas, como também no que diz respeito à facilidade com que se pode circular pelo prédio. Tal concepção de projeto o caracteriza como um equipamento coletivo e plenamente acessível. Sua planta constitui-se de dois 
blocos protegidos pela cobertura: um circular, onde estão as lojas, e outro retangular, onde funcionava o centro comercial propriamente dito. Este núcleo comercial reunia supermercado, açougue, farmácia, feira e banco.

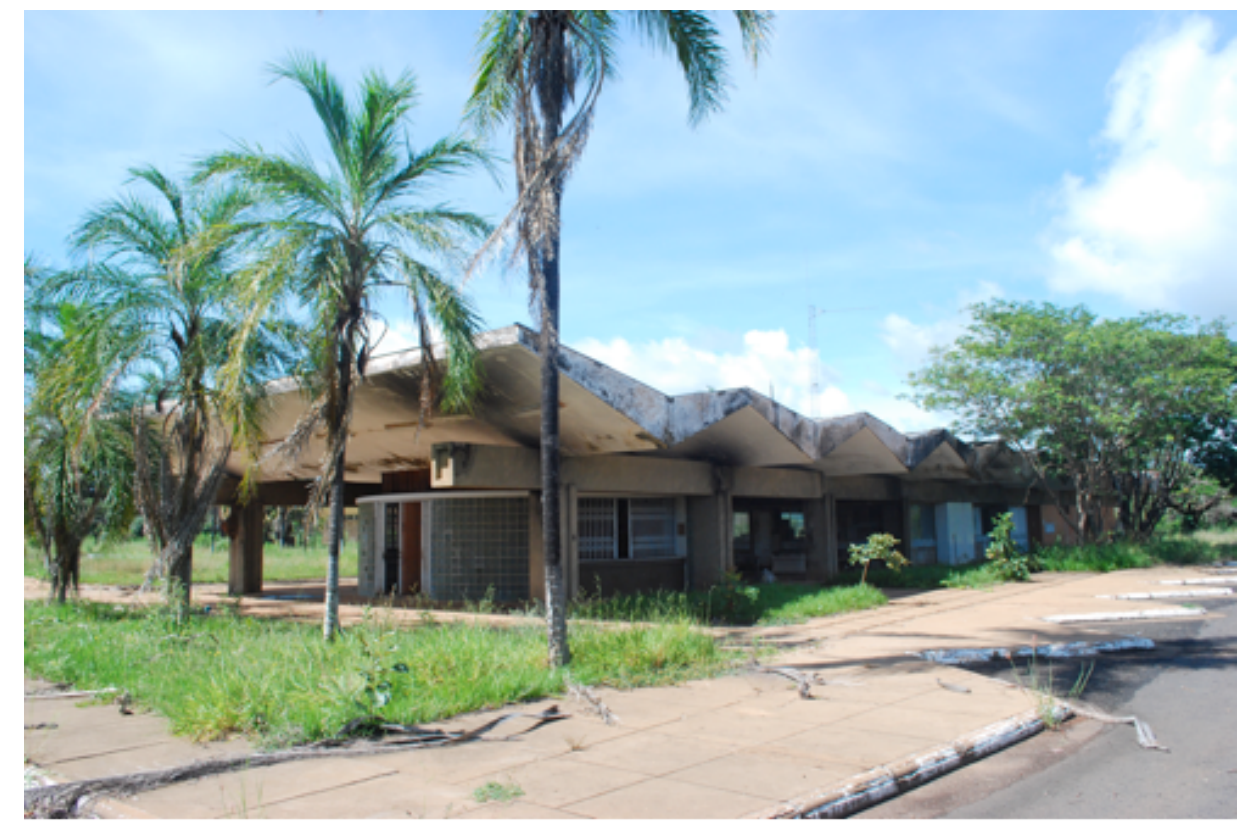

154. Vila de Operadores de Jaguara. Centro Comercial. Fonte: NUTHAU-FAUeD / UFU.
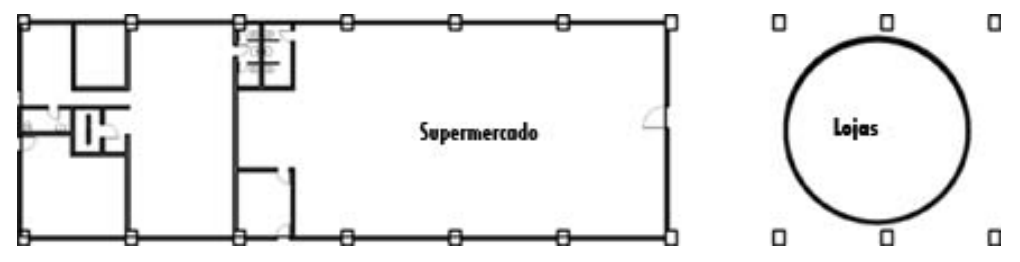

155. Vila de Operadores de Jaguara. Centro Comercial. Planta esquemática Fonte: NUTHAU-FAUeD / UFU.

O edifício para a Administração e Lavanderia é paralelo ao Centro Comercial, dialogando com este pelo desenho de sua cobertura, do tipo "borboleta". Todavia, se no edifício para o Centro Comercial a permeabilidade se apresentava como premissa de projeto, no prédio para a Administração e 
Lavanderia, um volume se assentava no terreno de forma quase hermética, traduzindo um caráter restrito. Ao lado de um espelho d'água, o edifício que é todo revestido exteriormente em pedra natural, foi organizado em dois blocos, divididos por um pátio central. Diante do espalho d'água e sobre o telhado borboleta está um bloco frontal destinado à administração da vila, onde se encontra um acesso público. No bloco posterior, tem-se outro acesso para a área da lavanderia.

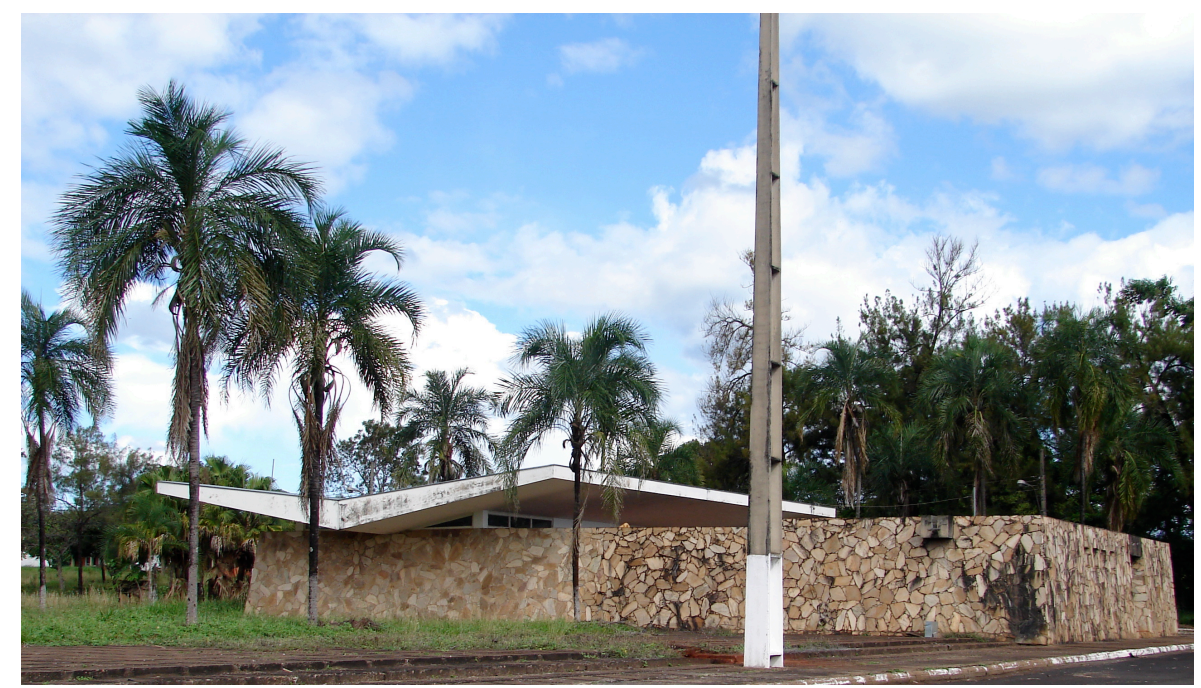

156. Vila de Operadores de Jaguara. Administração/Lavanderia. Fonte: NUTHAU-FAUeD / UFU.

157. Vila de Operadores de Jaguara. Administração/Lavanderia. Planta. Fonte: NUTHAU-FAUeD / UFU.

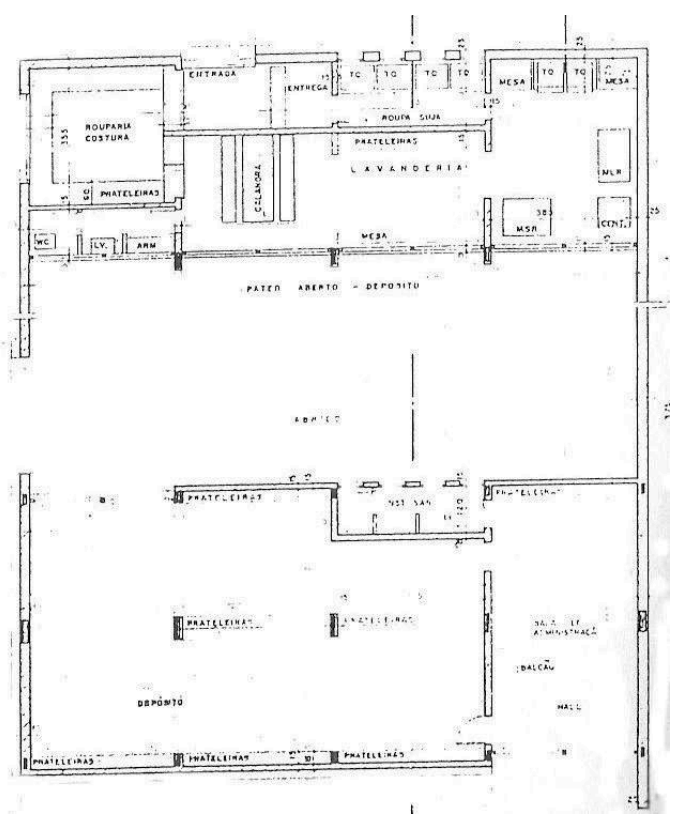




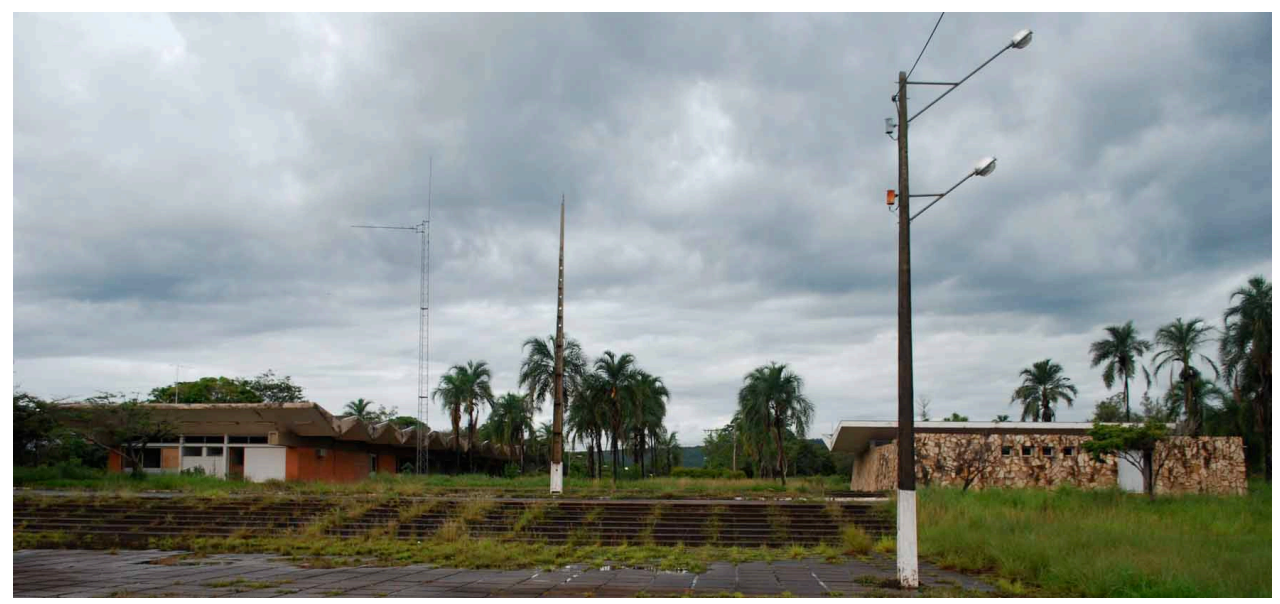

158. Vila de Operadores de Jaguara. À esquerda, o Centro Comercial e à direita, Administração e Lavanderia. Fonte: NUTHAU-FAUeD / UFU.

A Estação de Passageiros foi projetada para atender a pequena pista de pouso asfaltada, com 1100 metros lineares. No projeto original para o galpão de embarque/desembarque, os sanitários formavam com a cozinha, um núcleo hidráulico, existindo uma parede que ocultava o bloco de serviços e se estendia além dos limites da cobertura. Não foram assim executados. A edícula, de tipologia pavilhonar, é constituída por apenas um bloco de serviços com cozinha e sanitários, sendo a alternância dos planos vazados e opacos, a composição plástica que se destaca.

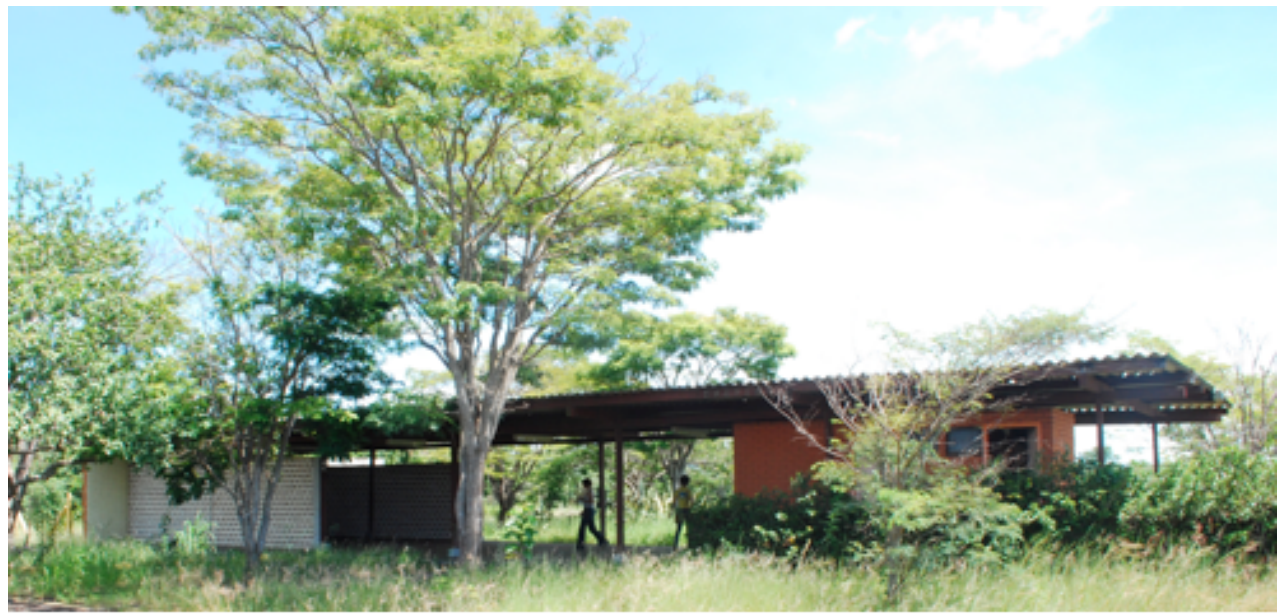

159. Vila de Operadores de Jaguara. Estação de Passageiros. Fonte: NUTHAU-FAUeD / UFU. 


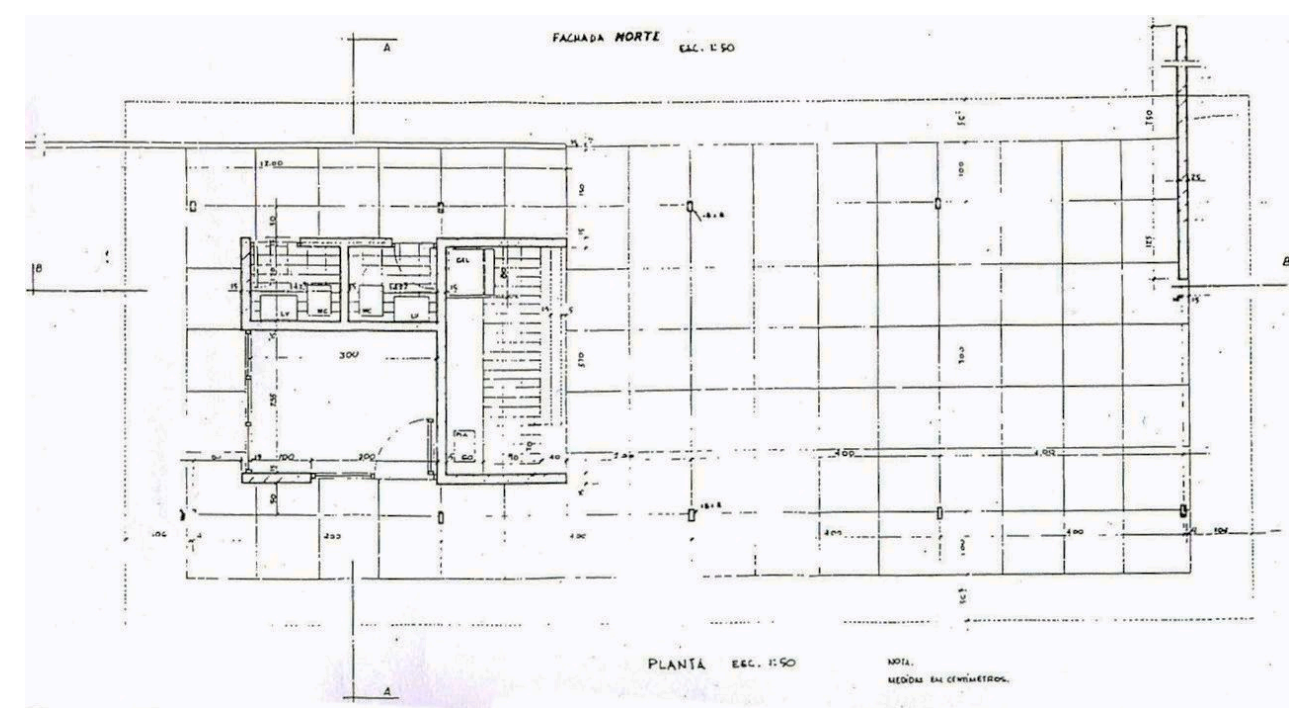

160. Vila de Operadores de Jaguara. Estação de Passageiros. Planta. Fonte: NUTHAU-FAUeD / UFU.

Por último, o projeto para o prédio da Portaria e Recepção foi organizado em dois blocos administrativos separados por uma área aberta, onde bancos de alvenaria formam um ambiente de espera. Os dois blocos servem de apoio para a cobertura, explorada enquanto elemento plástico e que unifica plasticamente o prédio. O projeto previu uma sala para os guardas, com um núcleo de apoio com copa e sanitários. A guarita deveria controlar o acesso à pista de pouso e ao conjunto da Vila de Operadores de Jaguara.

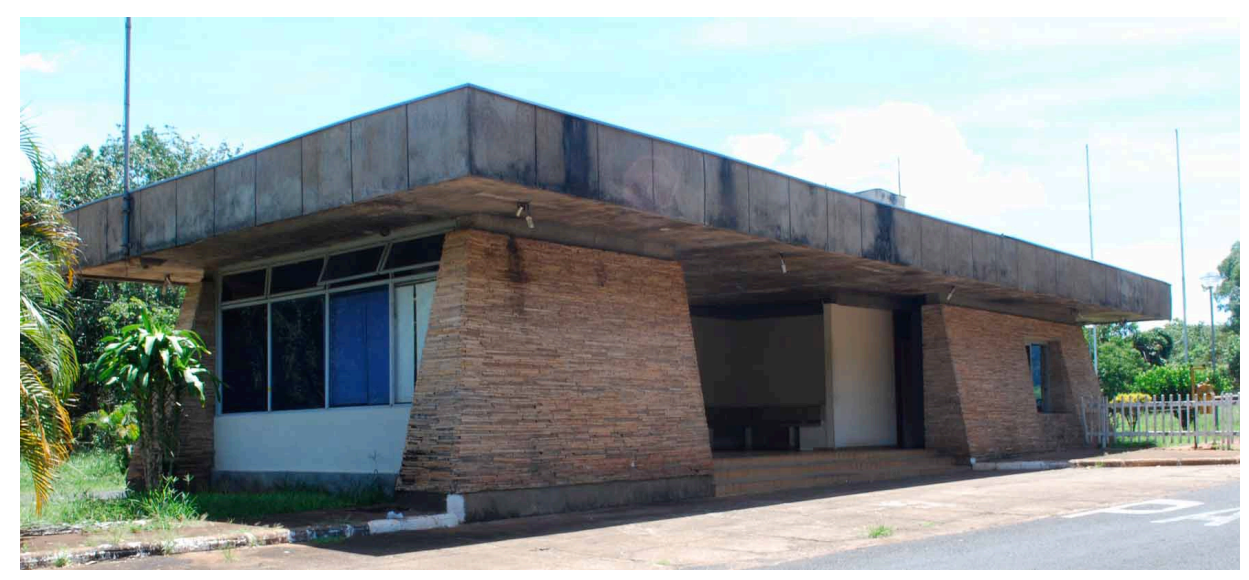

161. Vila de Operadores de Jaguara. Portaria e Recepção. Fonte: NUTHAU-FAUeD / UFU. 


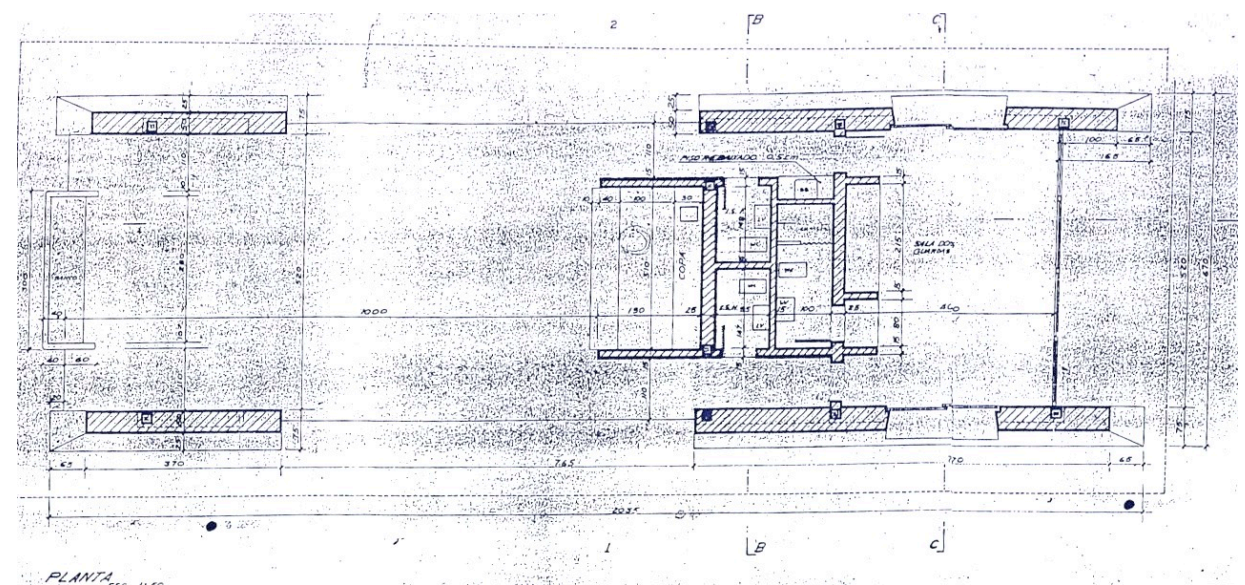

162. Vila de Operadores de Jaguara. Portaria e Recepção. Planta. Fonte: NUTHAU-FAUeD / UFU.

Formando atualmente o Parque Náutico de Jaguara, a antiga vila de operadores se encontra atualmente em um contexto distinto do seu original. A vila foi desativada em 1989, quando continuou apenas com a usina em operação, necessitando apenas de três funcionários. (CROZARA; CAPPELLO, 2011).

Em 21 de Dezembro de 2006, a Vila de Operadores de Jaguara foi leiloada, com lance mínimo fixado em de $\mathrm{R} \$ 5,9$ milhões. Foi adquirida pela empresa Borá Agropecuária - única a participar da licitação - por $\mathrm{R} \$ 6,36$ milhões pagos em 24 parcelas. (GUERRA, 2008)

A empresa familiar, constituída pelo professor Ivan Sebastião Barbosa Afonso e suas três filhas arquitetas, implantaram o Parque Náutico de Jaguara, um complexo turístico, aproveitando do reservatório da usina, com $33 \mathrm{~km}^{2}$, destinado ao lazer náutico e ao turismo ecológico, já existente na região da Serra da Canastra. Segundo os proprietários, a intenção é integrar Jaguara, que já faz parte do Circuito dos Lagos, no Circuito da Canastra, transformando o local em um endereço turístico de referência nacional. (CROZARA; CAPPELLO, 2011).

A privatização do setor elétrico, desde o governo $\mathrm{FHC}$, mantida pelo governo Lula, resultou na venda de vilas de operadores de usinas hidrelétricas 
por todo Brasil. Esse fato ocorreu principalmente por meio do que se chamou de “desverticalização", a partir da Lei $\mathrm{n}^{\circ} .10848$, de 2004, que definiu um novo modelo para o setor. Desse modo, deu-se continuidade a venda de residências isoladas de vilas operadoras e no caso de Jaguara, a venda da vila inteira. (GUERRA, 2008)

Situada razoavelmente longe do perímetro urbano de Sacrameno, podese dizer que a venda da Vila de Operadores de Jaguara foi uma alternativa para recuperar os investimentos perdidos da companhia hidrelétrica.

CEMIG PÕE UMA CIDADE À VENDA - Estatal leiloa por R\$ 6 milhões vila com casas e estrutura de lazer e serviço. Atualmente só uma pessoa mora no local - Se você sonha em ser dono de uma cidade completa, com direito a casas montadas e estrutura de lazer e serviço completa, deixe reservados $R \$ 6$ milhões em sua conta bancaria. A CEMIG vai por à venda uma cidade inteira no Triângulo Mineiro com 70 casas, hotel, clube recreativo, restaurantes, centro comercial, igreja, ambulatório e até um aeroporto por esse preço. $O$ inusitado leilão faz parte do programa de desativação das vilas de operadores montadas perto das usinas da estatal. Localizada na zona rural de Sacramento, quase divisa com são Paulo (...), a vila residencial a ser vendida em março do ano que vem, foi erguida na década de 70, para receber os trabalhadores da Usina de Jaguara, em operação no Rio grande desde 1971 e com capacidade de produzir $484 \mathrm{mw}$ de energia elétrica. A vila existe há 36 anos, mas nos últimos três está praticamente vazia. $A$ exceção é o Engenheiro belo-horizontino Nilton Braz de Moura Silva, funcionário e responsável pela usina e único morador de toda a cidade (...). (ESTADO DE MINAS, 19/09/2006 apud GUERRA, 2008, p. 137)

Segundo as visitas feitas pelos pesquisadores do NUTHAU-UFU, o parque está operando com o hotel ativo, cerca de dez residências já foram reformadas e destinadas à hotelaria, alguns imóveis já foram vendidos, a escola 
foi colocada a disposição da Prefeitura Municipal de Sacramento, até quando for necessário, e o clube recebe alguns eventos esporadicamente.

As residências reformadas, que estão sendo alugadas por temporadas, permanecem com a linguagem do projeto original, porém algumas residências já vendidas passaram por reformas, as quais vêm modificando as concepções originais de projeto. Nestas, das mais bruscas modificações, estão a adição de cobertura de duas águas com telha cerâmica, a pintura sobre os revestimentos originais e a adição de muros com cercas metálicas e muretas de alvenaria. Algumas casas que ainda não foram vendidas, naturalmente, já apresentam problemas como rachaduras, esquadrias quebradas, infiltrações, muros caindo e deterioração dos materiais de revestimento.

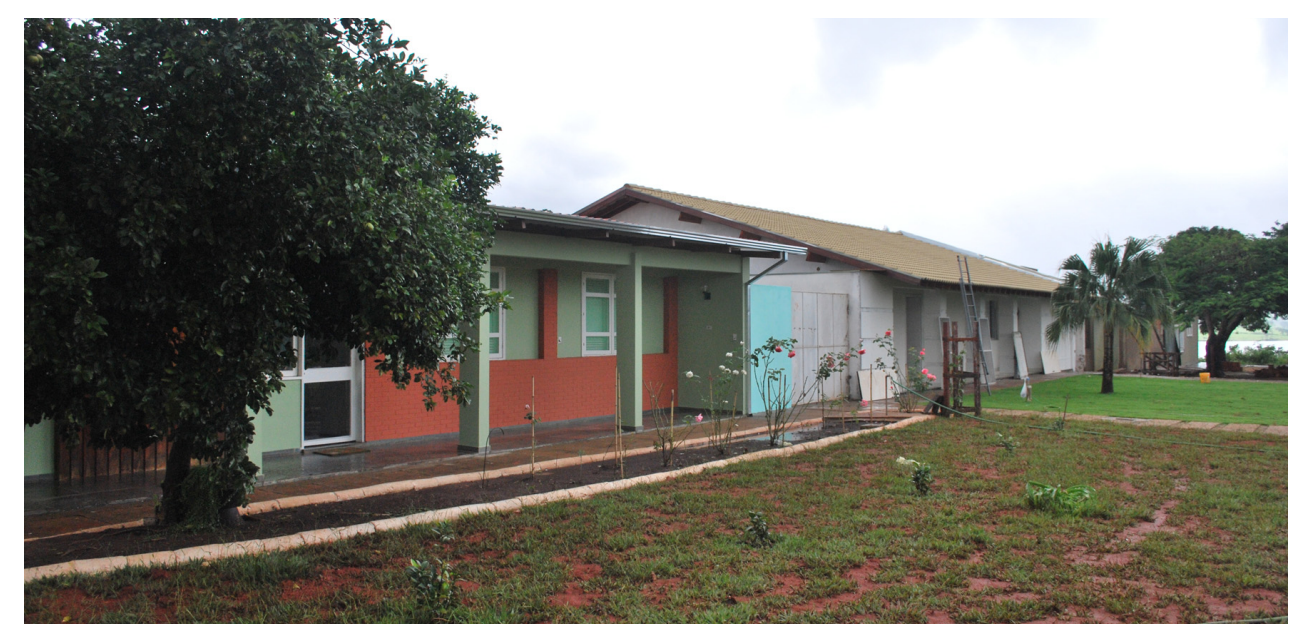

163. Vila de Operadores de Jaguara. Residências reformadas. Fonte: NUTHAU-FAUeD / UFU.

O hotel, o clube e a escola também passaram por pequenas reformas a fim de dá-los novamente condições de uso, mas não se nota grandes mudanças que os descaracterizassem do projeto original. Os demais equipamentos urbanos permanecem sem uso e sem manutenção, uma vez que não são necessários para o funcionamento do parque náutico, como a Casa de Visitas, o Centro Comercial e o Ambulatório. O Templo, como edifício simbólico e monumental, 
ainda é frequentado, mantém-se aberto e bem cuidado. No plano urbano original da vila não se nota modificações.

No ano de 2011, a empresa responsável pelo atual Parque Náutico de Jaguara, divulgou em seu site a candidatura do complexo para Centro de Treinamento de Seleções (CTS), na Copa do Mundo de 2014, e para a hospedagem de delegações nas Olimpíadas de 2016 no Brasil, onde também buscava sediar alguns jogos. Sacramento estrava na disputa entre as cidades mineiras com o intuito de buscar melhorias de infra-estrutura para o município.

Nas divulgações feitas pelo site do Parque Náutico de Jaguara, também observou-se que outro objetivo era atrair, por meio desses eventos, uma massa da população, divulgando dessa forma, o complexo turístico de Jaguara, agregando valor ao empreendimento. Somado à isso, a empresa responsável pelo parque esperava que os benefícios de infra-estrutura conquistados através dos jogos, pelos órgãos municipais, estaduais e federais chegassem até 0 parque. Em Agosto de 2012, a FIFA e o Comitê Organizador Local (COL) anunciaram a escolha das cidades brasileiras para Centro de Treinamento de Seleções na Copa de 2014, onde Sacramento não havia sido incluída entre os 54 destinos escolhidos.

[...] traremos milhares de turistas estrangeiros e nacionais, que viajarão constantemente, centenas de jornalistas que divulgarão os nossos destinos diariamente, pelos meios de comunicação do Mundo. E, o mais importante, virão oportunidades de negócios. [...]depois, certamente, toda a Região estará mais conhecida e mais viabilizada para se tornar um grande destino turístico nacional. (PARQUE NÁUTICO DE JAGUARA, disponível em $<$ http://parquenauticodejaguara.com.br/site/>, acessado em Outubro de 2011) 
Situada distante dos maiores núcleos populacionais do Triângulo Mineiro e Alto Paranaíba, a antiga Vila de Operadores de Jaguara é um acervo arquitetônico moderno com potencial para ser reconhecido como tal pela população local e dos arredores do pequeno município de Sacramento. As diversas formas de inserção da arquitetura moderna na região, principalmente as ocorrências encontradas em cidades com menos de 10 mil habitantes, integram um material com potencial avanço nas pesquisas sobre a produção da arquitetura moderna no Triângulo Mineiro e Alto Paranaíba.

Por exemplo, percebeu-se que nessas pequenas cidades, a arquitetura moderna chegou por meio de ações pontuais, de modo que não se disseminou uma linguagem moderna erudita na dinâmica construtiva de muitas cidades, no que diz respeito ao cânones apregoados para a nova arquitetura brasileira. Todavia, essa inserção se dava, por vezes, através da colocação de elementos que foram se tornando característicos dessa arquitetura, principalmente em residências, como os pilares esguios colocados sobre as marquises, alguns dispostos em forma de "v", outros fazendo alusão aos pilares do Palácio da Alvorada em Brasília, o telhado borboleta, os revestimentos em pedra, os enquadramentos da fachada, etc. É o caso de cidades como Estrela do Sul e Abadia dos Dourados, atualmente, com menos de 10 mil habitantes.

Há de se considerar, novamente, o papel da divulgação da construção de Brasília, desde final da década de 1950, como um fato importante para a disseminação da arquitetura moderna na região. Sobretudo, há de se considerar que a população passe a reconhecer por meio da divulgação de Brasília um novo valor, advindo da percepção pela população do surgimento de um fenômeno que enunciava o moderno como a linguagem escolhida pelo governo federal para os novos edifícios públicos do país.

Lembrando da participação de recursos do governo de Minas Gerais na construção da Vila de Operadores de Jaguara, ao adentrarmos na década de 
1970, a atuação do poder público pareceu ser ainda essencial, sobretudo, para a difusão da arquitetura moderna nas menores cidades do Triângulo Mineiro. Por exemplo, foram encontradas algumas obras padronizadas, como os projetos para fóruns, geridos pelo governo do estado de Minas Gerais. São projetos similares, os fóruns para as cidades de Monte Alegre de Minas e Campina Verde, e os fóruns de Prata, Estrela do Sul e Rio Paranaíba. ${ }^{21}$ Em comum, esses edifícios apresentam uma estética próxima do "brutalismo" ${ }^{22}$, no Brasil, um tipo de produção ligada à arquitetura moderna da escola paulista, cujo uso do concreto aparente destacava as formas monumentais da estrutura do edifício, uma característica bastante utilizada na arquitetura brasileira das décadas de 1970 e 1980. Em muitas dessas pequenas cidades, essas obras padronizadas são os únicos exemplares de uma produção moderna.

A Vila de Operadores de Jaguara é um conjunto moderno pouquíssimo conhecido, tanto pelos moradores da cidade de Sacramento, quanto pela população geral da mesorregião do Triângulo Mineiro e Alto Paranaíba e pela historiografia nacional da arquitetura brasileira. Ainda, por estar situada fora do perímetro urbano de Sacramento, sua utilização, o conhecimento da existência de uma arquitetura moderna no local e, consequentemente, sua salvaguarda, são dificultados. Embora isso, a obra é um exemplo da chegada da arquitetura moderna no interior do país, não somente por meio de sua popularização e difusão de alguns elementos, mas também, por meio de projetos de alto nível.

\footnotetext{
${ }^{21}$ Esses projetos também se repetem em outras cidades do estado de Minas Gerais, algumas ocorrências foram encontradas na meso-região da Zona da Mata, segundo pesquisa da Universidade Federal de Viçosa, apresentada pela então coordenadora do núcleo Docomomo Minas Gerais, Marta Camisassa durante o Seminário Internacional Brasil, Argentina e México, em 2012.

${ }^{22} \mathrm{Em}$ geral, existem duas definições acerca da produção brutalista: a do uso do concreto bruto de Le Corbusier, desde a Unidade de Habitação de Marselha (1947-52), e usado em proposta totalmente estética, que "rompe definitivamente com o funcionalismo restrito (BRUAND, 1981); e o Novo Brutalismo inglês, imbuído de total carga ideológica, dentro de um contexto no qual a catástrofe das cidades europeias no segundo pós-guerra era latente, e onde o uso do material bruto aparece como uma espécie de volta extremada aos princípios da década de vinte, sem qualquer concessão a uma estética se não da essência do material (BRUAND, 1981).
} 


\section{A Igreja Espírito Santo do Cerrado}

Importante na minha vida foi minha viagem ao Nordeste e o trabalho que eu desenvolvi em todo o Polígono da Seca. Aí eu vi a liberdade. A não importância da beleza, da proporção, dessas coisas, mas a de um outro sentido profundo, que eu aprendi com a arquitetura, especialmente as arquiteturas dos fortes, ou primitivas, populares, em todo Nordeste do Brasil.

[...] O discurso era outro. Era um discurso sócio-político, ligado diretamente à economia e à história não só na Bahia, mas no Nordeste todo, e que não pode ser abolido. Em Pernambuco, no Triângulo Mineiro, no Ceará, no Polígono da Seca, se encontrava um fermento, uma violência, uma coisa cultural no sentido histórico verdadeiro de um País, que era o conhecer de sua própria personalidade. (BARDI, 1959 apud FERRAZ, 1993, p.153 - grifo nosso)

Por ocasião de uma estadia em Uberlândia, em 1975, a arquiteta Lina Bo Bardi foi convidada pelo artista e amigo Edmar de Almeida, junto aos Freis Egydio Parisi e Fulvio Sabia, para desenvolver o projeto da construção de uma capela que atendesse à comunidade de um bairro periférico da cidade e às ordens dos Franciscanos e das Carmelitas de Pés Descalços. Relutante a princípio, tendo recusado o convite, provavelmente pelo descrédito que mantinha pelas instituições religiosas ${ }^{23}$, a arquiteta volta na sua decisão ao saber que a construção da obra se daria por meio de mutirão, formado pela comunidade do Bairro Jaraguá. Não obstante, resolve também doar o projeto.

A arquiteta italiana, nesse momento, já detinha reconhecimento profissional pelos projetos realizados no Brasil, como o MASP (Museu de Arte de São Paulo), construído entre 1956 e 1968. Lina Bo Bardi formou-se na Faculdade

\footnotetext{
${ }^{23}$ Lina era atéia. Um texto interessante sobre a ideia de Lina sobre a religião é Repassos (FERRAZ, 1993).
} 
de Arquitetura da Universidade de Roma, em 1939, e veio para o Brasil em 1946, junto ao marido Pietro Maria Bardi, reconhecido desde à época da Itália por sua atuação no campo das artes e da cultura.

Nos poucos escritos de Lina sobre a Igreja Espírito Santo do Cerrado, aliado à outros conhecidos sobre diversos temas, percebe-se que a possibilidade de fazer a Igreja proporcionou à arquiteta duas possibilidades, que seriam o estudo da técnica aliada ao conhecimento vernacular - tema recorrente na sua carreira, sendo possível usar materiais simples e do próprio local - e a possibilidade de um trabalho conjunto, onde a coletividade significaria a retirada da população de um estado de passividade permanente, do qual, segundo ela, sofria o interior brasileiro, recolocando por meio daquele "evento" a consciência política e cultural da população. Sobre a Igreja Espírito Santo do Cerrado, nas palavras de Lina:

A igreja foi construída por crianças, mulheres, pais de família, em pleno cerrado. Construída com materiais muito pobres, coisas recebidas de presente, em esmolas. É tudo dado. Mas não no sentido paternalista, mas com astúcia, de como pode se chegar a coisas com meios muito simples. (BARDI, L. B apud FERRAZ, M. C. (coord.), 1999)

O que houve de mais importante, na construção da Igreja do Espírito Santo, foi a possibilidade de um trabalho conjunto, entre arquiteto $e$ mão de obra. De modo algum foi um projeto elaborado num escritório de arquitetura e enviado simplesmente para a execução, pois houve um contato fecundo e permanente entre arquiteto, equipe e o povo que se encarregou de realizá-lo. (BARDI apud FERRAZ, 1993, p. 214) 
Em meados da década de 1970, nacionalmente, o país vivia o estopim da multiplicação dos sindicatos trabalhistas e demais movimentos populares, cujo foco mirava a repressão do então Regime Militar. ${ }^{24}$ Aqui, também, é o movimento social, a base do contexto da estrutura compositiva desenhada para a "Igrejinha da Lina", como é tratada por aqueles que a reconhecem enquanto ícone arquitetônico brasileiro.

Como povo que se organiza, teria sido a forma da igreja se aliar aos movimentos políticos, junto às possibilidades arquitetônicas do contexto construtivo local, que Lina teria voltado atrás na sua recusa quando convidada para fazer o projeto. No artigo "Repassos", sobre a Exposição Documento, em 1975, Lina demonstra bem seu pensamento em relação à religião e a passividade, no sentido do conformismo, que repugnava na população de fé:

Nos períodos difíceis da história de um país quando as estruturas se desfazem, o misticismo é o último recurso que tira o homem da passividade. [...] O desejo de "fazer", de por a criatividade a serviço de alguém, a procura de uma saída para uma situação humana mais digna, acham no misticismo uma solução provisória. (BARDI, 1975 apud FERRAZ, 1993, p. 200)

Curioso ainda é pensar na grande amizade que se estendeu entre Lina e Frei Egydio Parisi, o qual a arquiteta homenageou ao nomear uma cadeira de sua autoria, alguns anos mais tarde. Desconfia-se que esta relação só pôde ser estabelecida por meio dos diálogos envolvidos no processo de concepção e construção da Igreja Espírito Santo do Cerrado, assim como pela característica do frei, conhecido por ter sido "crítico contundente" e participante ativo nas questões políticas e principais acontecimentos da cidade, como descrevem moradores de Uberlândia:

\footnotetext{
${ }^{24}$ Sobre os movimentos populares ocorridos nas décadas de 1970 e 1980 no Brasil, indicamos: SADER, Eder. Quando novos personagens entraram em cena: experiências e lutas dos trabalhadores da grande São Paulo 1970-1980. 4.ed. São Paulo: Paz e Terra, 2001.
} 
Frei Egídio, que conheci em Uberlândia, era cidadão do mundo. Disse-me que foi capelão do Exército Italiano na II Guerra Mundial. Era severo crítico de políticos locais. Dava-Ihes balinhas-doces para que deixassem "a amargura de lado". Frei Egídio foi um "uberlandino" participante dos principais acontecimentos na cidade, crítico contundente e amigo de gente muito poderosa. ${ }^{25}$

Uma das apostas da arquiteta era que a arquitetura poderia ser feita pelo povo, em uma recuperação do sentido social da construção do espaço, conectado à realidade. Sua aposta foi iniciar uma mudança de paradigmas desde a escola de formação do arquiteto, o qual "tem que atuar, mas a partir da base, não da cúpula" (BARDI, 1979 apud RUBINO, 2008). Existiu em toda a atuação de Lina a confiança no potencial das forças populares existentes no Brasil para juntas transformarem o arquiteto empreendedor que surgia como um atuante com consciência política.

Em Uberlândia, a Igreja Espírito Santo do Cerrado soma-se às discussões existentes, naquele momento, inseridas dentro do trabalho de Lina, que consegue por meio do projeto, colocar em prática algumas proposições. Certamente, em fins da década de 1970, o impacto gerado pela construção da “igrejinha”, no periférico Bairro Jaraguá, não mobilizou mais - para fora dos limites do bairro - as discussões em torno da produção arquitetônica da cidade do que para as discussões acerca dos rumos da arquitetura brasileira e do próprio conjunto da obra da arquiteta. Por exemplo, o projeto de Lina não é reconhecido pela população local como uma arquitetura moderna, porque, de fato, não segue a mesma linha formal dos edifícios modernos construídos em Uberlândia até então. Somado a isso, a igreja ainda não interfere substancialmente na produção arquitetônica da região, não chegando a difundir, por exemplo, uma nova tipologia na construção de igrejas. Pode nos parecer, então, pouco importante a

${ }^{25}$ CORREIO DE UBERLÂNDIA, Uberlândia, 2009. 
construção da Igreja Espírito Santo do Cerrado para o cenário regional, se partirmos, primeiramente, das questões locais antes das globais. No entanto, o projeto de Lina para o Triângulo Mineiro, demonstra-se importante, sobretudo, por colocar a região na rota de discussões acerca da produção e dos rumos da arquitetura moderna nacional.

A proposta original requeria à Lina, o projeto para uma igreja, centro comunitário e casa paroquial, com aposentos para três religiosas. A concepção para o projeto foi feita no ano de 1975 , tendo sua construção perdurado até o ano de 1982. Nesse processo, Lina Bo Bardi teve a colaboração dos arquitetos Marcelo Ferraz e André Vainer, do "Conselho de Construção" formado por moradores do Bairro Jaraguá, da organização alemã "Adveniat", sediada em Essen e a qual doou fundos para a realização do projeto, além do Comissariado Fransciscano de Nossa Senhora de Fátima do Brasil e do artista Edmar de Almeida.

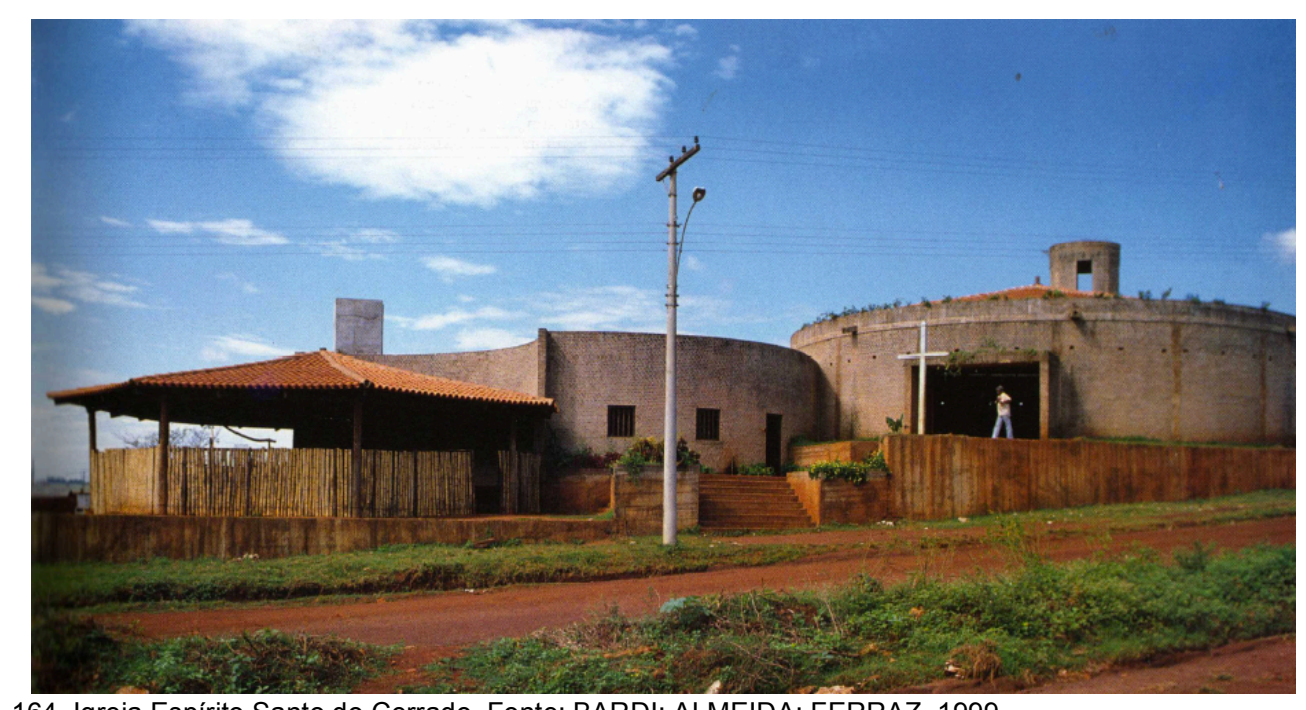

164. Igreja Espírito Santo do Cerrado. Fonte: BARDI; ALMEIDA; FERRAZ, 1999.

A igreja foi desenhada em três volumes circulares e conectados, utilizando-se propositalmente do desnível do terreno para estabelecer a hierarquia dos espaços religiosos e comunitários através de várias cotas. No 
nível mais alto, onde o terreno faz esquina com a Rua Mangabeiras, foi colocada a área de celebração dos cultos (nave), em seguida, um nível que guarda a moradia para as religiosas e a administração, um terceiro nível onde foram dispostos um salão para festividades e reuniões (galpão), e por último, no nível mais baixo, uma quadra de futebol em grama fazendo esquina entre a Avenida dos Mognos e a Avenida dos Ipês. O campanário da igreja foi colocado na porção mais alta do terreno, junto ao salão de celebração, estabelecendo um contraste entre este elemento vertical e a concepção primada pela horizontalidade do desenho de Lina. O acesso ao edifício se dá pela Avenida dos Mognos, através de uma escadaria que chega ao segundo nível do edifício, distribuindo dali, o fluxo para os outros três níveis.

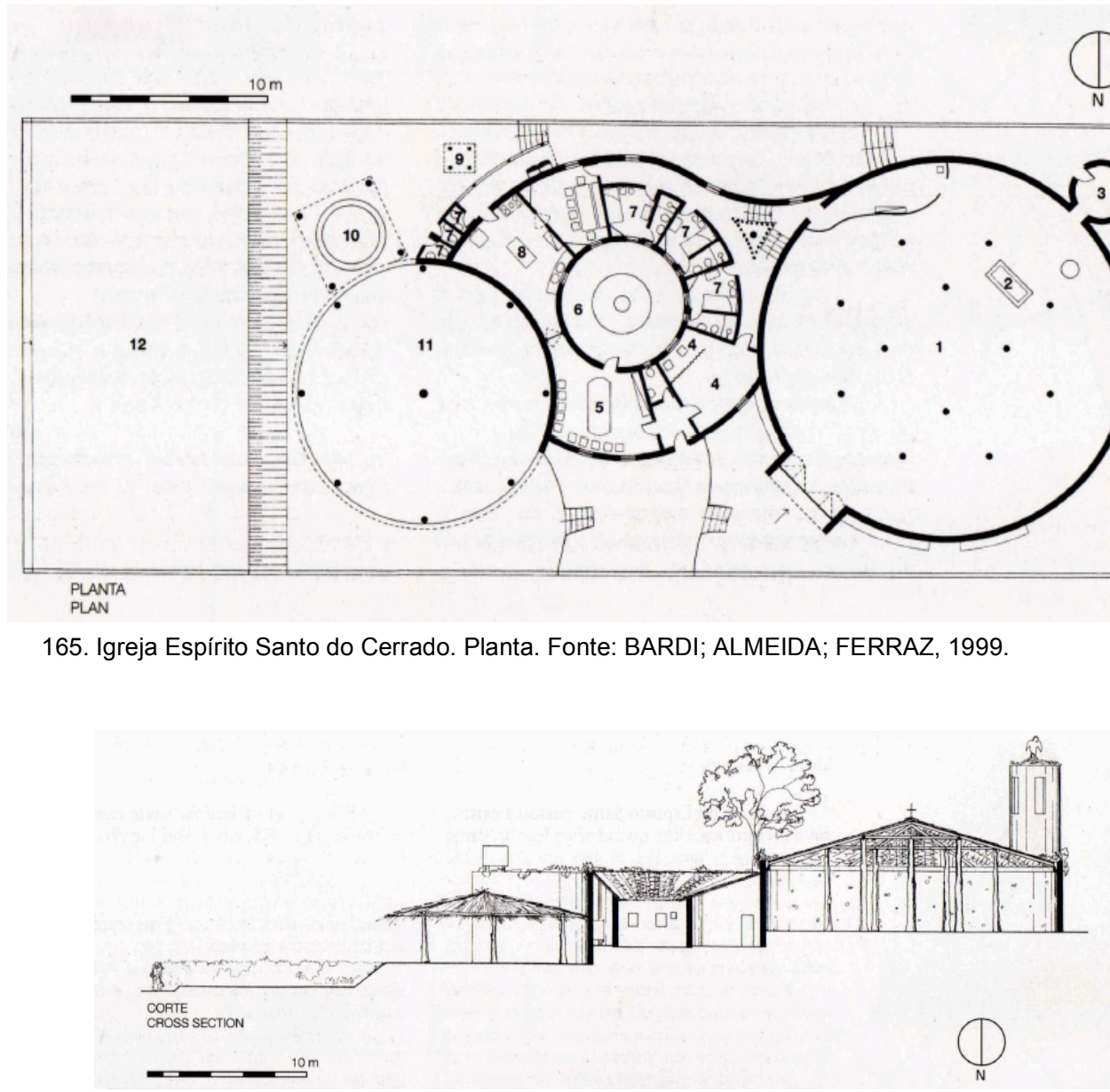

166. Igreja Espírito Santo do Cerrado. Corte. Fonte: BARDI; ALMEIDA; FERRAZ, 1999. 


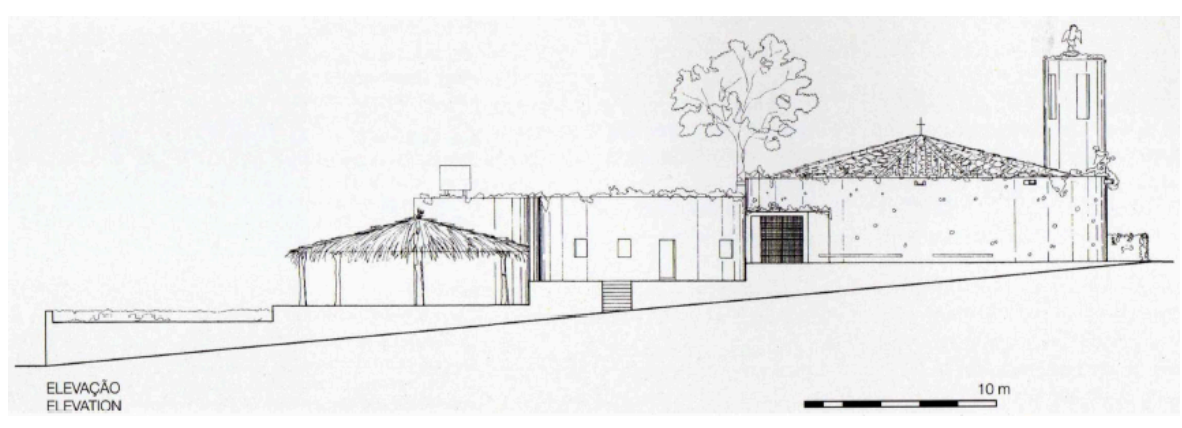

167. Igreja Espírito Santo do Cerrado. Elevação. Fonte: BARDI; ALMEIDA; FERRAZ, 1999.

Todo sistema construtivo da igreja foi feito em misto de alvenaria estrutural, concreto armado, madeira e aço, onde a maior parte dos materiais utilizados foram extraídos do próprio local, como o tijolo de barro e a madeira de aroeira da região para a estrutura portante. A vedação, em tijolo maciço, ficava sem acabamento em todo exterior do edifício e em alguns locais internos, como no salão de celebrações. A telha de barro, tipo "capa canal", foi usada na cobertura, assentada sobre estrutura de madeira. As esquadrias das portas e janelas também foram executadas em madeira.

A nave, onde eram realizados os cultos, tinha um peculiar sistema de iluminação natural, feito por meio de pequenas aberturas, correspondentes a retirada de alguns tijolos. Também, foram colocadas telhas translúcidas sobre o altar-mor, delimitado por um patamar dois degraus acima do nível do piso. Desse modo, Lina conseguiu que os raios solares que penetrassem o salão de 
celebrações conferissem também um sentido simbólico. Nesse volume do edifício, a arquiteta desenha uma jardineira que circunda toda cobertura, onde deveria crescer a vegetação típica do cerrado.

O volume correspondente à casa paroquial foi organizado ao redor de um pátio central descoberto, em alusão à um claustro, onde se voltam algumas janelas. É composto por três quartos, cada qual com seus respectivos banheiros, parlatório, banheiro social, sala de reuniões e cozinha, por onde chega-se à lavanderia externa. Esse volume pode ser acessado tanto por meio do salão de celebrações - por onde se chega à um corredor com iluminação também feita por meio de um rasgo na cobertura onde foram colocadas telhas translúcidas - como por uma porta localizada defronte a escadaria externa da igreja. As paredes internas, aqui, receberam pintura na cor branca sobre reboco. Nas áreas molhadas, foi aplicado o piso em cimento e nos demais cômodos, o tabuado de madeira. No pátio central, onde foi usado o seixo rolado para o piso, encontra-se um jardim.

O salão de festividades (galpão) remetia à uma oca indígena. Foi executado em estrutura de madeira e telha cerâmica, que aqui, diferente dos demais volumes, não foi escondida por platibanda. Originalmente, esse espaço tinha fechamento em meia altura com bambu e chão de terra batida. Em seguida, um nível mais baixo, foi feito o campinho de futebol, com piso de grama.

Ao longo do tempo, a Igreja Espírito Santo do Cerrado sofreu diversas intervenções, dentre elas, algumas que visavam corresponder as novas necessidades da comunidade. Atualmente, a igreja foi reformada segundo projeto dos arquitetos Marcelo Ferraz e André Vainer, que estiveram presentes, junto à Lina Bo Bardi, no processo de construção da igreja. Em 1991, A Igreja Espírito Santo do Cerrado foi tombada por lei municipal, e em 1997, teve tombamento estadual homologado pelo IEPHA-MG (Instituto Estadual do Patrimônio Histórico e Artístico do Estado de Minas Gerais), tornando-se patrimônio histórico estadual. 


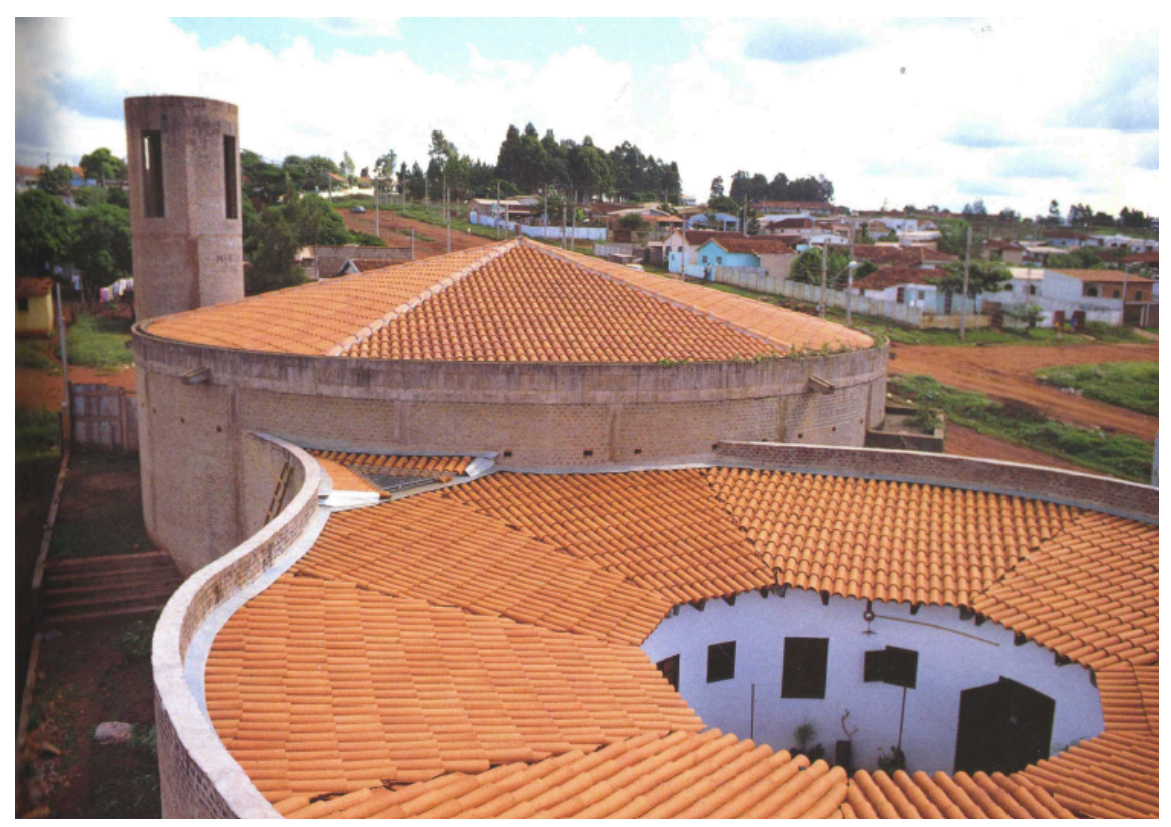

168. Igreja Espírito Santo do Cerrado. Vista aérea. Fonte: BARDI; ALMEIDA; FERRAZ, 1999.

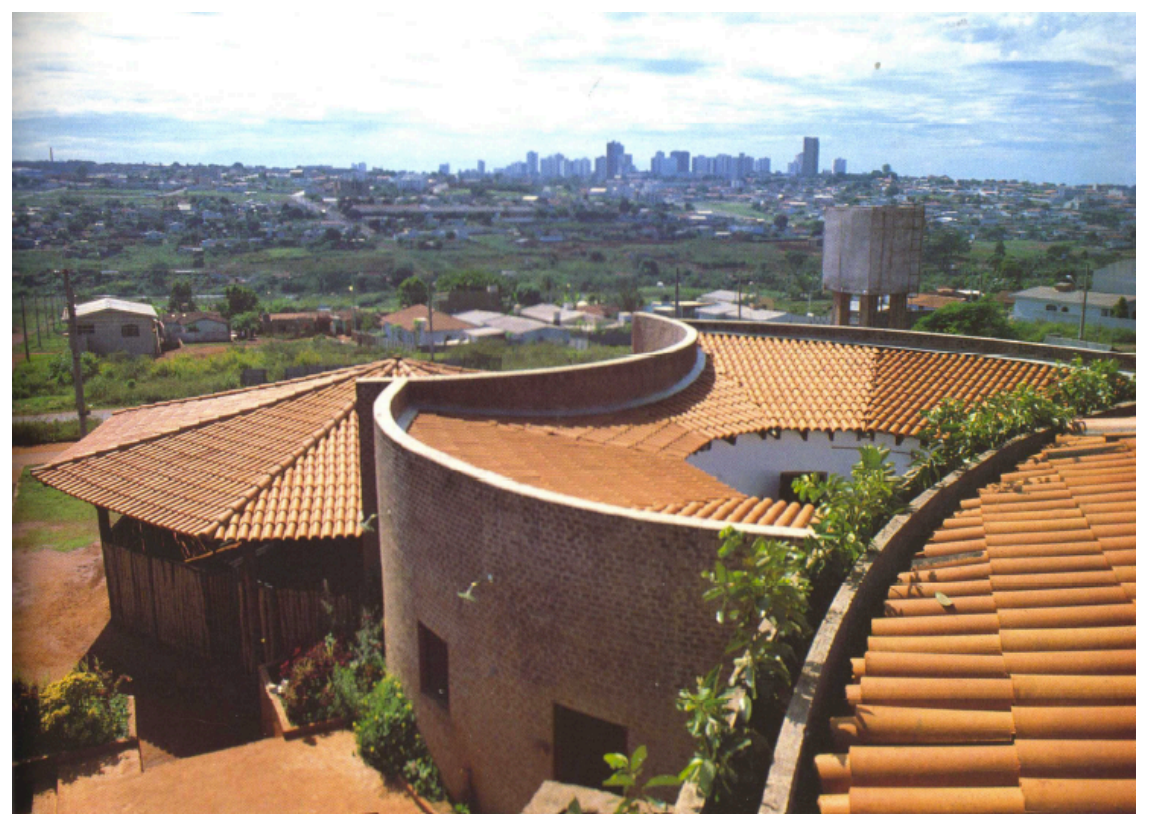

169. Igreja Espírito Santo do Cerrado. Vista aérea. Fonte: BARDI; ALMEIDA; FERRAZ, 1999. 


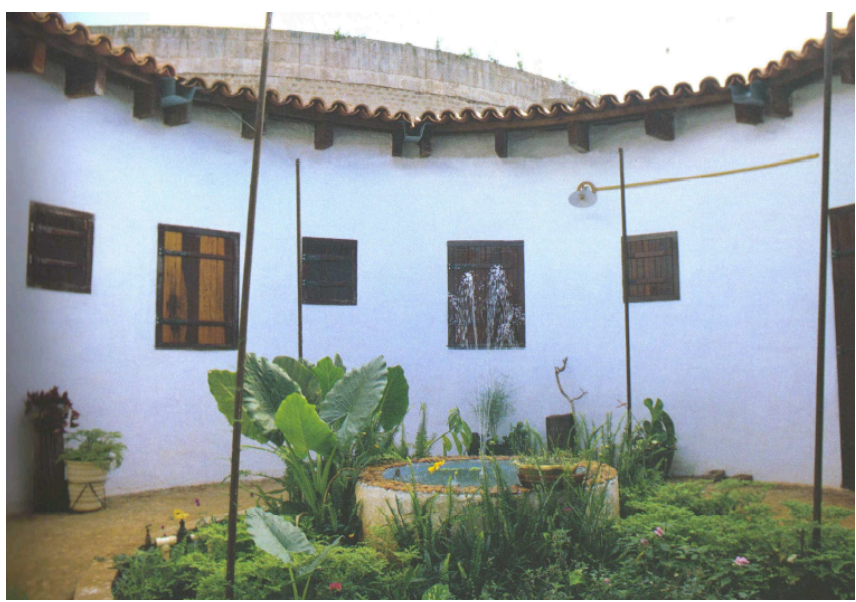

170. Igreja Espírito Santo do Cerrado. Pátio Casa Paroquial. Fonte: BARDI; ALMEIDA; FERRAZ, 1999
171. Igreja Espírito Santo do Cerrado. Galpão. Fonte: BARDI; ALMEIDA; FERRAZ, 1999.

172. Igreja Espírito Santo do Cerrado. Altar-mor. Fonte: BARDI; ALMEIDA; FERRAZ, 1999.
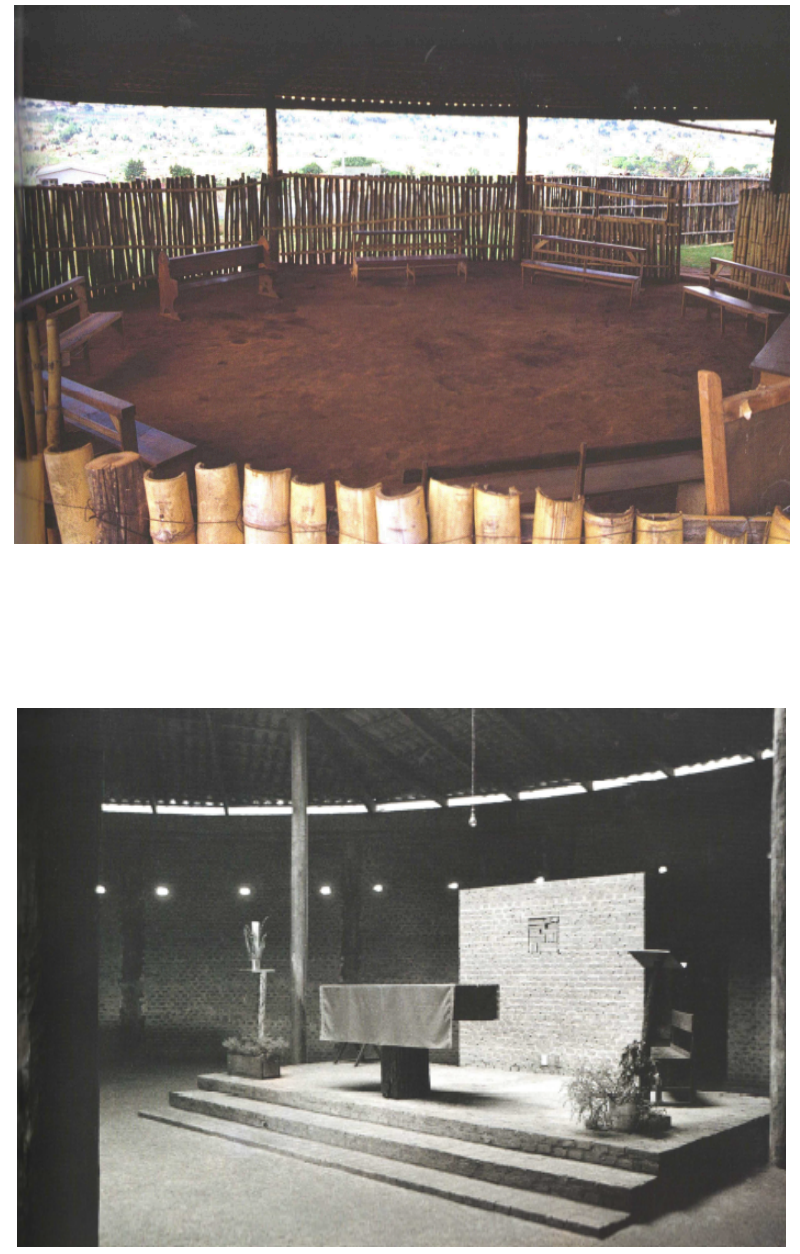


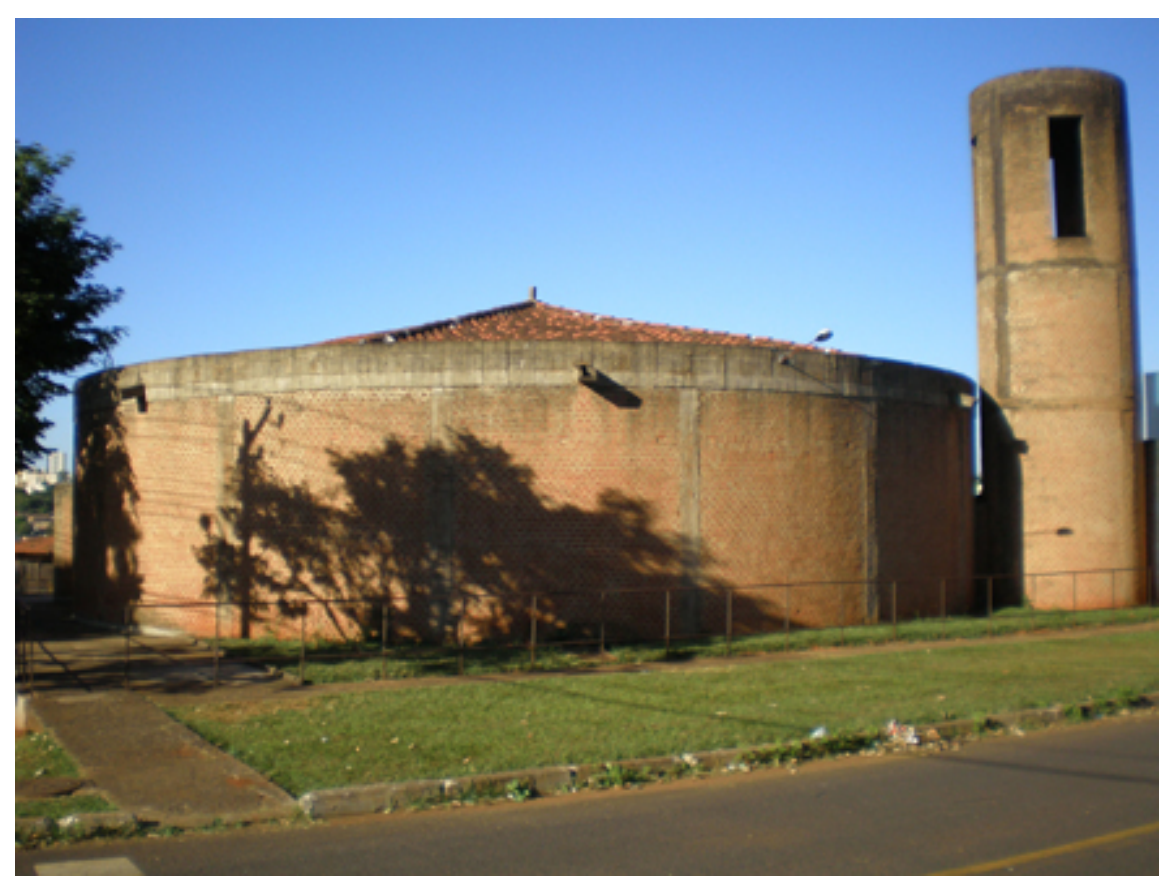

173. Igreja Espírito Santo do Cerrado. Vista do campanário. Fonte: NUTHAU-FAUeD / UFU. 


\section{Para concluir e seguir}

Com o objetivo de dar continuidade aos trabalhos já existentes sobre o tema da difusão da arquitetura brasileira para fora dos grandes centros, em específico, na região do Triângulo Mineiro e Alto Paranaíba, decidiu-se por primar o trabalho na observação da documentação pré-existente - e da recolhida no processo como parte do material encontrado em jornais e revistas - contrapondo um tipo de análise que, calcado em hipóteses, poderia amarrar o estudo do tema.

Fazia parte dos esforços do trabalho, não somente identificar os protagonistas dessa história, como também alguns mecanismos de apropriação da nova linguagem arquitetônica inserida. Deixamos que o material recolhido nos guiasse nesse processo, colocando em aberto, a priori, o escopo territorial e temporal da nossa pesquisa. Era previsto que, para evitar que o trabalho se tornasse prolixo ou um catálogo de obras modernas do Triângulo Mineiro, seria preciso selecionar as obras e os elementos mais significativos. Desse modo, ficaram de fora um grande número de obras e arquitetos na construção final do trabalho.

$\mathrm{Na}$ perspectiva de continuação dos esforços em compreender os processos de difusão da arquitetura moderna no Triângulo Mineiro e Alto Paranaíba, pensando também nos trabalhos de outros autores realizados até aqui ${ }^{1}$, podem ser apontados alguns potenciais de caminhos a seguir.

Seria interessante a continuação das pesquisas em materiais primários como jornais e revistas no período entre as décadas de 1950 e 1970. Embora pequeno, o material que conseguimos coletar demonstrou-se um potencial para compreensão dos diversos valores atribuídos à arquitetura moderna no

\footnotetext{
${ }^{1}$ Ver introdução do trabalho.
} 
desenvolvido econômico da região. A compreensão do moderno como valor, há muito, vem sido discutida por interesse do Prof. Dr. Carlos Alberto Ferreira Martins, nas reuniões do Arqbras (Grupo de Pesquisa em Arquitetura e Urbanismo no Brasil - IAU/USP).

Outro potencial está nos esforços de compreensão das relações entre as formações acadêmicas dos arquitetos e suas produções nas cidades do Triângulo Mineiro e Alto Paranaíba. O NUTHAU (Núcleo de Teoria e História da Arquitetura e Urbanismo - FAUeD/UFU), tem observado, só para citar, a ligação do processo de verticalização de algumas cidades com a formação que os arquitetos que participaram desse processo receberam nas escolas de arquitetura que cursaram, como aqueles formados pela Escola de Arquitetura da Universidade Mackenzie.

Ainda são diversos os arquitetos e obras levantados e que necessitam serem estudados, principalmente na década de 1970, quando a dinâmica construtiva da região aumenta significadamente como vimos no capítulo inicial da dissertação. A complexidade que toma a linguagem projetual dos edifícios nesse período merece atenção ainda maior.

O primeiro número da revista mineira Pampulha, de Novembro/Dezembro de 1979, trouxe uma mostra da produção de alguns arquitetos mineiros na década de 1970. Com exceção da Igreja São Benedito, de Wagner Schroden, em Uberaba, todos as obras publicadas eram em Uberlândia: a Rodoviária Presidente Castelo Branco, citada no trabalho, dos arquitetos Fernando Graça, Flávio Almada e Ivan Cupertino; duas residências e o projeto do Teatro Manuel Madruga, do arquiteto Saul Vilela; a residência de hóspedes da Granja Rezende da arquiteta Freuza Zechmeister; e o Fórum 
Abelardo Pena ${ }^{2}$, em Uberlândia, dos arquitetos José Laender de Castro e Roberto Pinto Manata.

O projeto para o Fórum de Uberlândia estava afinado com a tendência nacional, nesse momento, para o "Brutalismo Paulista". Assim como o fórum de Uberlândia, outros projetos na região foram elaborados seguindo a cartilha de elementos para a concepção de uma obra "brutalista", constituindo-se outro potencial de prosseguimento das pesquisas.

O conjunto da obra do arquiteto Elifas Lopes Martins constitui um acervo a ser estudado e compreendido nos diálogos entre a arquitetura regional e nacional a partir do início da década de 1970. Essa pesquisa já foi iniciada sob coordenação da professora Maria Beatriz Camargo Cappello, com o projeto de pesquisa "Arquitetura Moderna em Uberlândia - Arquiteto Elifas Lopes Martins", entre 1999 e 2001. Formado pela Universidade de Brasília (UNB), em 1968, sua arquitetura faz parte de um conjunto de obras que vão se distanciando das primeiras gerações de arquitetos modernos da cidade.

Nesse mesmo período, obras importantes trazem novas discussões. Em 1979, o escritório de Rino Levi ${ }^{3}$ projeta a Casa de Hóspedes para a CBMM (Companhia Brasileira de Metalurgia e Mineração) na cidade de Araxá. Na casa de Hóspedes percebeu-se a retomada de certas características vernaculares, como a utilização da telha cerâmica. O projeto estava afinado com o debate nacional e internacional acerca da arquitetura contemporânea, colocando em prática novas questões, como a introdução da cultura local ao ideário moderno e o papel do lugar enquanto definidor do projeto arquitetônico. A busca de uma

\footnotetext{
${ }^{2} \mathrm{O}$ projeto para o Fórum de Uberlândia fazia parte de um centro cívico na área central da cidade, onde estariam reunidos os edifícios dos três poderes municipais em uma grande praça, a atual Praça Sérgio Pacheco. O projeto, parcialmente executado, tinha os jardins elaborados por Burle Marx, seu segundo projeto na região, desde o Conjunto Paisagístico para a Estância do Barreiro, em Araxá, abordado no segundo capítulo.

${ }^{3} \mathrm{O}$ projeto é posterior ao falecimento de Rino Levi. Foi assinado pelos arquitetos Roberto Cerqueira César, Luis Roberto Carvalho Franco, Paulo Bruna e Carlos Eduardo de Paula.
} 
identidade por meio da cultura local já tinha sido colocada no projeto de Lina Bo Bardi para a Igreja Espírito Santo do Cerrado.

A medida em que a década de 1970 avança, a produção moderna do Triângulo Mineiro e Alto Paranaíba reflete a pluralidade de concepções projetuais mostrada no primeiro número da revista Pampulha, que também é reflexo da produção arquitetônica das grandes capitais do país nesse momento. O trabalho demonstrou que o moderno produzido nesse espaço-tempo no Triângulo Mineiro e Alto Paranaíba é pouco hegemônico e não contém uma unidade específica. Há de se considerar também que, se o moderno "tarda" a se difundir na região pelos anos de 1950, a partir da construção de Brasília essa produção passa a ser simultânea, em discussões e concepções projetuais, com o moderno produzido no Rio de Janeiro e São Paulo, e também, com outras cidades do país.

É importante ainda relativizar que, embora o quadro sócio-políticoeconômico elaborado mostre o desenvolvimento da região marcado pela característica de "território de passagem", o andamento da pesquisa revelou que a arquitetura moderna produzida não foi construída para atender à uma demanda efêmera ou espontânea, mas planejada a partir de necessidades urbanas, construtivas, e que englobam os vários tipo de representatividade do moderno.

Para concluir e seguir, reiteramos, como dito na introdução do trabalho, que as várias pesquisas até aqui não esgotam o tema, potencializam, sim, novas formas de compreensão e debate sobre a difusão da arquitetura moderna do Triângulo Mineiro e Alto Paranaíba. Espera-se, sobretudo, em âmbito nacional, auxiliar o preenchimento das lacunas da historiografia da arquitetura brasileira, bem como acentuar a pauta da necessidade e dos mecanismos de sua preservação. 


\section{Referências}

Gerais:

1. ARGAN, G. C. (1970). L'Arte Moderna - 1770/1970. 13. ${ }^{\circ}$ ed. Firenze, Sansoni Editore, 1985.

2. BENEVOLO, L. (1976). História da Arquitetura Moderna. São Paulo: Editora Perspectiva.

3. BLAY, Eva Alterman. Eu não tenho onde morar. São Paulo, Nobel, 1985.

4. BONDUKI, Nabil G. Origens da Habitação Social no Brasil. Arquitetura Moderna, Lei do Inquilinato e Difusão da Casa Própria. São Paulo, Estação Liberdade/Fapesp, 1998.

5. BOTEY, Josep M. Oscar Niemeyer (obras y proyectos). Barcelona: Gustavo Gili, 1996.

6. BRANDÃO, C. A. (1989). Triângulo: capital comercial, geopolítica e agroindústria. Belo Horizonte. Dissertação (Mestrado) - Centro de Planejamento e Desenvolvimento Regional/UFMG.

7. CONSIGLIERI, Victor. A Morfologia da Arquitetura 1920 - 1970. Volume II. Lisboa, 1994.

8. CORREIA, Telma de Barros. Patrimônio Industrial e Agroindustrial no Brasil: a forma e a arquitetura dos conjuntos residenciais. In: Segundo Seminário de Patrimônio Agroindustrial: Lugares da Memória, São Carlos, 2010.

9 ; GHOUBAR, Khaled; MAUTNER, Yvonne. Brasil, suas fábricas e vilas operárias. In: PÓS - Revista do Programa de Pós-Graduação em Arquitetura e Urbanismo da FAUUSP/Universidade de São Paulo. Faculdade de Arquitetura e Urbanismo. Comissão de PósGraduação - v.1 (1990) - São Paulo: FAU, 1990 - n. 20, dez. 2006.

10. DINIZ, A. M. A. ; BATELLA, Wagner Barbosa . O Estado de Minas Gerais e suas regiões: um resgate histórico das principais propostas oficiais de regionalização. Sociedade \& Natureza, Uberlândia, v. 17, n.43, 2005.

11. FERNANDES, O.R. Uberlândia Impressa: a década de 1960 nas páginas de jornal. Dissertação (Mestrado) Inhis/UFU, Uberlândia, 2008.

12. FILGUEIRAS GOMES, Marco Aurélio (2005). Cultura Urbanística e Contribuição Modernista. Brasil, anos de 1930-1960. In: Cadernos PPGFAUUFBa - Urbanismo Modernista. Brasil 19301960. Edição Especial. Salvador, UFBa, pp. 11-30.

13. FRAMPTON, K. (1987). História Critica da Arquitetura Moderna. Barcelona, Gustavo Gili.

14. FREITAS, P.S.R.; SAMPAIO, R.C. (coord). Sinopse do diagnóstico sócio-econômico do Triângulo Mineiro e Alto Paranaíba (1940-1980). Uberlândia: UFU, 1985. 
15. LeMOS, C. B.; DANGELO, A. G. D.; CARLASALADE, F. L. (orgs.). Escola de Arquitetura da UFMG: lembranças do passado, visão de futuro. Belo Horizonte: Editora Escola de Arquitetura da UFMG, 2011. $241 \mathrm{p}$.

16. LIMA, Sandra Cristina Fagundes de. Uberlândia Ilustrada, 1935 a 1961: a revista e seu editor. História e Perspectiva (36 - 37): 209 - 246, jan. Dez. 2007.

17. LOURENÇO, Luís A, B. Das Fronteiras do Império ao Coração da República: o Território do Triângulo Mineiro na Transição para a Formação Sócio-Espacial Capitalista na Segunda Metade do Século XIX. 2007. 306p. Tese (Doutorado em Geografia Humana) - Universidade de São Paulo, São Paulo.

18. MESQUITA, A.P. ; SILVA, H. Q. As linhas do tecido urbano. 0 sistema de transportes e a evolução urbana em Uberlândia-MG. Uberlândia: Roma, 2006.

19. MOTA, J. C. Planos diretores de Goiânia, década de 60: a inserção dos arquitetos Luís Saia e Jorge Wilhein no campo do planejamento urbano. São Carlos, Dissertação (Mestrado), EESC USP, 2004.

20. RODRIGUES, Orlanda. Uberlândia Impressa: a década de 1960 nas páginas de jornal. Dissertação de Mestrado, Uberlândia. Universidade Federal de Uberlândia, 2008.

21. SOARES, B.R. Uberlândia: da Cidade Jardim ao Portal do Cerrado - Imagens e Representações no Triângulo Mineiro. Tese de Doutorado, São Paulo. USP/FFLCH/Departamento de Geografia, 1995.

22. SOUZA, Eneida Maria de (org.). Modernidades Tardias. Belo Horizonte: UFMG, 1968.

23. TEMER, Ana Carolina Rocha Pessôa. Colhendo notícias, plantando imagens - A reconstrução da história da TV Triângulo a partir da memória dos agentes de seu telejornalismo. São Bernardo do Campo, SP. Dissertação de mestrado. UMESP.

24. TEMER, A. C. R. P. . Edson Garcia Nunes e a TV Triângulo em Uberlandia: anotações sobre a história de uma emissora de televisão no interior. In: Alaic 2006, 2006, São Leopoldo. Alaic 2006. Bogotá: Alaic, 2006.

Arquitetura Moderna Brasileira:

1. ARANTES, Otília Beatriz Fiori. Brasília, síntese das artes. In: Mário Pedrosa, itinerário crítico. São Paulo: Scritta, 1991.

2. BASTOS, Maria A. J.; ZEIN, Ruth V. Brasil: arquiteturas após 1950. São Paulo: Perspectiva, 2010. 
3. BASTOS, Maria Alice Junqueira. Pós-Brasília: rumos da arquitetura brasileira. São Paulo, Perspectiva, FAPESP, 2003.

4. BRUAND, Y. (1981). Arquitetura Contemporânea no Brasil. São Paulo: Editora Perspectiva.

5. CASTRIOTA, L. B.; OlIVEIRA, Cleo Alves Pinto de ; PERPÉTUO, Maini de Oliveira. 0 ensino na primeira escola de arquitetura do Brasil . Arqtexto, São Paulo, v. 066, 2005.

6. CONDE, Luiz P. Depoimento. In: MAGALHÃES, Sérgio F. Arquitetura Brasileira após Brasília/Depoimentos: Luiz Paulo Conde, Julio Katinsky, Miguel Pereira. Rio de Janeiro: IAB/RJ, 1978, p.10-25.

7. DOURADO, G. O. M. Modernidade Verde: jardins de Burle Marx. Dissertação (Mestrado em Arquitetura e Urbanismo). Escola de Engenharia de São Carlos, Universidade de São Paulo, São Carlos, 2000

8. FICHER, Sylvia; ACAYABA, Marlene. Arquitetura moderna brasileira. São Paulo: Projeto Editores, 1982.

9. FREIRE, Adriana L. de Almeida. Os sentidos da difusão da arquitetura moderna brasileira (1945-1970). Projeto de pesquisa (Doutorado) - Programa de Pós-Graduação em Arquitetura e Urbanismo da Escola de Engenharia de São Carlos, Universidade de São Paulo. São Carlos, 2011.

10. GUERRA, Abilio (org.). Textos fundamentais sobre história da arquitetura moderna brasileira, v.1-2, São Paulo: Romano Guerra, 2010.

11. GUIMARAENS, D.; CAVALCANTI, L. Arquitetura kitsch: suburbana e rural. Rio de Janeiro: Paz \& Terra,. 1982.

12. LARA, Fernando Luiz. The rise of popular modernist architecture in Brasil. Gainesville: University Press of Florida, 2008.

13. LEMOS, C. A. C. (1979). Arquitetura Brasileira. São Paulo: Melhoramentos e Edusp, 1979.

14. MACEDO, O. L. C. Francisco Bolonha; ofício da modernidade. Dissertação (Mestrado em Arquitetura e urbanismo) - EESC - USP, São Carlos, 2003.

15. MARTINS, C. A. F. (1988). Arquitetura e Estado no Brasil: Elementos para uma Investigação sobre a Constituição do Discurso Modernista no Brasil; a Obra de Lúcio Costa. São Paulo. Dissertação (Mestrado) - FFLCH - USP, $1^{\circ}$. Capítulo. Uma trama recorrente.

16. O Fixo e o fluxo: arquitetura na fronteira entre o construído e o sócio-cultural. In:

Feldman, Sarah; Fernandes, Ana. (Org.). O urbano e o regional no Brasil contemporâneo. Salvador: EDUFBA/FEUNESP/ANPUR, 2007, p. 191-204. 
17. . (1999). "Há algo de irracional...". Notas sobre a historiografia da arquitetura brasileira. In: GUERRA, Abilio (org.). Textos fundamentais sobre história da arquitetura moderna brasileira, v.2, São Paulo: Romano Guerra, 2010, p.131-168.

18. MINDLIN, H. (1956). Arquitetura moderna no Brasil; prefácio de S. Giedion; organizador da edição brasileira. Lauro Cavalcanti; tradução de Paulo Pedreira. 2.ed. Rio de Janeiro : Aeroplano Editora/IPHAN. 2000. Título original em inglês: Modern architecture in Brasil. New York : Reinhold.

19. OLIVEIRA, Ana Rosa de. Bourlemarx ou Burle Marx? Entrevista a Burle Marx. 1992. Disponível em: <http://www.vitruvius.com.br/entrevista/burlemarx/burlemarx_6.asp>. Acessado em: 30 jun.2009.

20. PEDROSA, Mário. (1957) Reflexões em torno da nova capital. In: ARANTES, Otília Beatriz Fiori (org.). Acadêmicos e modernos: textos escolhidos III. São Paulo: Edusp, 1998.

21. PESSÔA, José; VASCONCELLOS, Eduardo; REIS, Elisabete e LOBO, Maria (org.). Moderno Nacional. EduFF, Niterói, 2006. p. 169-181.

22. SEGAWA, Hugo; DOURADO, Guilherme Mazza. Oswaldo Arthur Bratke. São Paulo, ProEditores, 1997.

23. SOUZA, Eneida Maria de (org.). Modernidades Tardias. Belo Horizonte: UFMG, 1968.

24. XAVIER, A. org. (1987). Arquitetura Moderna Brasileira - Depoimentos de uma Geração. São Paulo, Editora Pini, Associação Brasileira de Ensino de Arquitetura e Fundação Vila Nova Artigas.

25. ZEIN, Ruth Verde. A Arquitetura da Escola Paulista Brutalista 1953-1973. Tese de doutoramento, PROPAR-UFRGS, 2005.

26. _ (1987). O futuro do passado ou as tendências atuais. In: GUERRA, Abilio (org.). Textos fundamentais sobre história da arquitetura moderna brasileira, v.1, São Paulo: Romano Guerra, 2010, p.117-162.

Arquitetura Moderna No Triângulo Mineiro E Alto Paranaíba:

1. AMARAL, Walmyr Lima; MORRISON, Walter L; FRANCO, Pedro Augusto Vasques. Fábrica Souza Cruz, Uberlândia, MG; projeto de arquitetura. In: Projeto. São Paulo, n.42, p.144, jul, 1982.

2. AMARAL, Walmyr Lima; MORRISON, Walter L; FRANCO, Pedro Augusto Vasques. Fábrica Souza Cruz, Uberlândia, MG: prêmio IAB-RJ; projeto de arquitetura. In: Projeto. São Paulo, n.20, p.13-18, maio, 1980. 
3. AZEVEDO, P. (1998). A Difusão da Arquitetura Moderna em Minas: O Arquiteto João Jorge Coury em Uberlândia. São Carlos, Dissertação (Mestrado), EESC - USP.

4. AZEVEDO, P.; GUERRA, M. E. João Jorge Coury, Um Moderno no Triângulo. Projeto, São

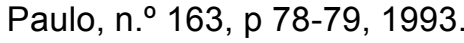

5. BARDI, L. B.; ALMEIDA, E.; FERRAZ, M. C. [coord.]. Igreja Espírito Santo do Cerrado. Portugal: Editorial Blau, 1999.

6. CROZARA, Letícia G. N; CAPPELLO, Maria B. C. Vila Dos Operadores da Usina Hidrelétrica de Jaguara: Análises Urbanas e Arquitetônicas. Belo Horizonte: $2^{\circ}$ Colóquio Ibero Americano Arquitetura e Documentação, 2011. CD-ROM.

7. DOCUMENTAÇÃO da Arquitetura Moderna no Triângulo Mineiro e Alto Paranaíba: História e $\begin{array}{llllll}\text { Preservação } & - & \text { Fichas de } & \text { Inventário. }\end{array}$ <http://www.faurb.ufu.br/doc_moderno/html/cidades0.html>. Acesso em: jun.2009.

8. FONTE Termal Andrade Junior. In: Revista Municipal de Engenharia. Secretaria Geral de Viação e Obras. vol.15, n. 4, out-dez, 1948.

9. GUERRA, M. E. (1998). As Praças Modernas de João Jorge Coury no Triângulo Mineiro. São Carlos, Dissertação (Mestrado), EESC - USP.

10. GUERRA, Maria Eliza A. Vilas Operadoras de Furnas nas Bacias dos Rios Grande e Paranaíba - da concepção à atualidade. Tese (Doutorado) IG/UFU, Uberlândia, 2008.

11. LAURENTIZ, L. (1993). Olhando as arquiteturas do cerrado. In: Projeto 163, São Paulo, maio, PP. 75-91.

12. LAZZARIN, A. L. ; SOUZA ALVES, H. V. ; CAPPELLO, M. B. C. Germano Gultzgoff e o Movimento Moderno em Uberaba. In: $1^{\circ}$ Seminário Docomomo Uberlândia-MG, 2010, Uberlândia. Caderno de Resumos - 1º Seminário Docomomo Uberlândia-MG, 2010. v. 01.

13. MANHAS, A.C.B.S. ; VILLELA, A. T. C. ; OLIVEIRA, J.C.C.B. A modernidade e a síntese das artes a partir das obras do arquiteto Wagner Schroden em Uberaba - MG In: 8 Seminário Docomomo Brasil - Cidade Moderna e Contemporânea: Síntese e Paradoxo das Artes, 2009, Rio de Janeiro - RJ.

14. MIRANDA, Ana Paula Tavares; CAPPELLO, Maria Beatriz Camargo. Arquitetura Moderna no Triângulo Mineiro e Alto Paranaíba: a Atuação Dos Grandes Escritórios. Horizonte Científico (Uberlândia), v. 1, p. 1-30, 2009.

15. MIRANDA, Ana Paula Tavares; CAPPELLO, Maria Beatriz Camargo. A Obra de Raphael Hardy Filho em Araxá-MG: As Instalações Industriais da Fertisa. In: $9^{\circ}$ Seminário Docomomo Brasil. Brasília, 2011. 
16. MIRANDA, Ana Paula Tavares. Arquitetura Moderna no Triângulo Mineiro e Alto Paranaíba e Produção Nacional pós 1950. In: Seminário Internacional Brasil - Argentina - México. A circulação das ideias na América Latina: o moderno na arquitetura e urbanismo. Uberlândia: UFU, 2012.

17. PORTO, Daniele Resende. O Barreiro de Araxá: Projetos para uma estância hidromineral em Minas Gerais. Dissertação de Mestrado, Escola de Engenharia de São Carlos, Universidade de São Paulo, São Carlos, 2005.

18. RIBEIRO, Patricia Pimenta Azevedo; LOPES, Cíntia M. Chioca (2001). Documentação da Produção Arquitetônica do Arquiteto João Jorge Coury em Uberlândia - Banco de Obras. Uberlândia: FAUeD /UFU, PIBIC/CNPQ, relatório de pesquisa (CD).

19. RIBEIRO, Patricia Pimenta Azevedo; MORAIS, Greiceana Marques Dias de (2001). Documentação da Produção Arquitetônica dos arquitetos e engenheiros nas décadas de $\mathbf{4 0}$ a 60 em Uberlândia - Banco de Obras. Uberlândia: FAUeD /UFU, PIBIC/CNPQ, relatório de pesquisa $(C D)$.

20. RIBEIRO, Elisa A.; VALE. Marília M. B. T. (2010) Compreensão da técnica construtiva utilizada nas edificações modernas nas cidades do Triângulo Mineiro e Alto Paranaíba. Uberlândia: FAUeD /UFU, PIBIC/CNPQ, relatório de pesquisa.

21. VALE, Marília Maria Brasileiro Teixeira. Conservação da Arquitetura Moderna - Estudo de Caso: A Estação Ferroviária de Uberlândia. Monografia de Conclusão de Curso de Especialização. CECI - ICCROM, 2010.

\section{Acervos:}

1. NUTHAU - Núcleo de Pesquisa em Teoria e História da Arquitetura e Urbanismo da Faculdade de Arquitetura, Urbanismo e Design da Universidade Federal de Uberlândia (FAUeD-UFU).

2. Arquivo Pessoal da Professora Patrícia Pimenta Azevedo Ribeiro.

3. Arquivo Público Municipal de Uberlândia

4. Arquivo Público Municipal de Uberaba

5. CEDHIS - Centro de Documentação e Pesquisa em História da Universidade Federal de Uberlândia. 


\section{Anexos}




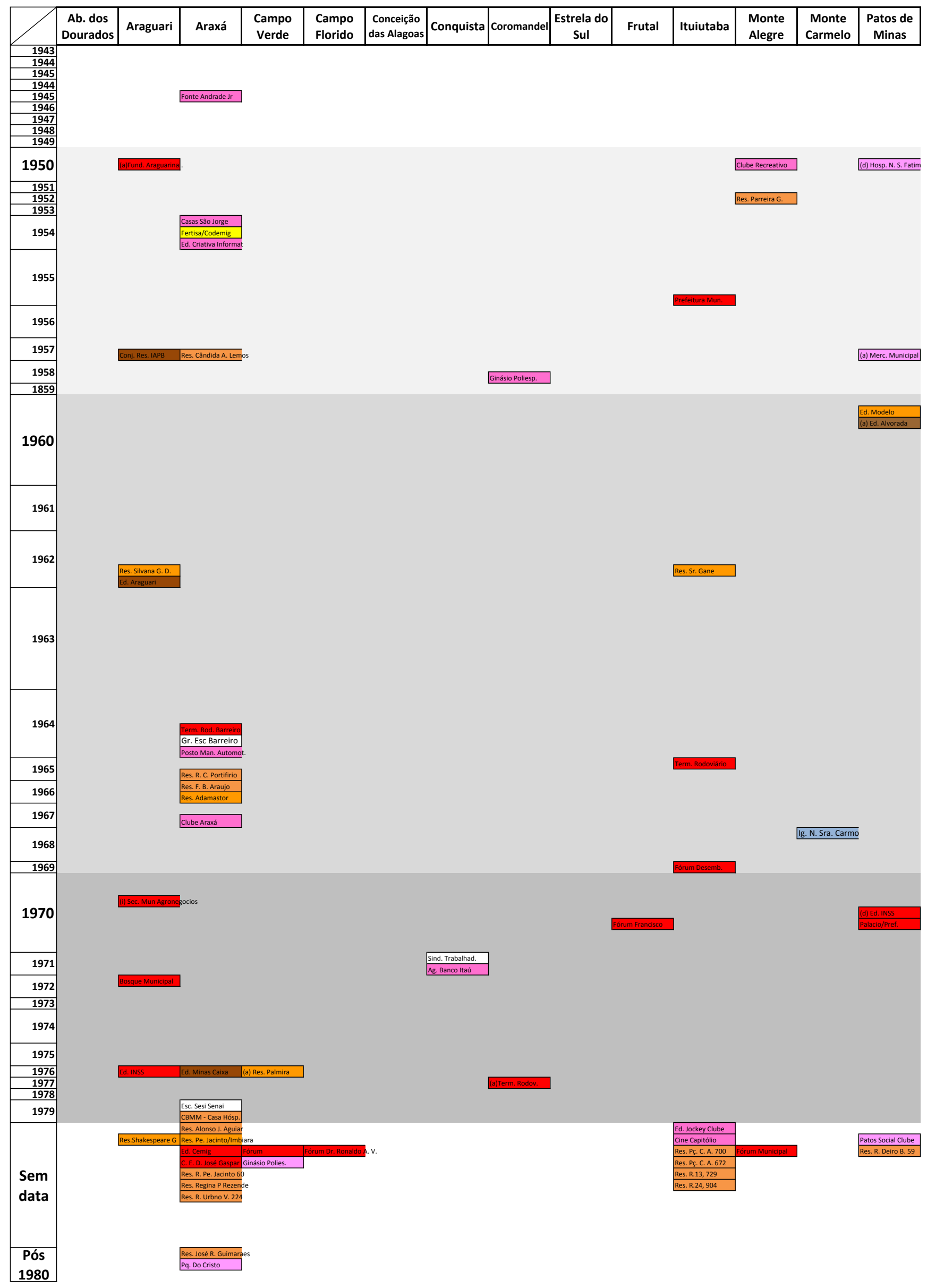

Arquitetura Moderna no Triângulo Mineiro e Alto Paranaíba Tabela: Data x Cidade x Tipologia 


\begin{tabular}{|c|c|c|c|c|c|c|}
\hline Patrocinio & Prata & $\begin{array}{c}\text { Rio } \\
\text { Paranaíba }\end{array}$ & Sacramento & Tupaciguara & Uberaba & Uberlandia \\
\hline
\end{tabular}

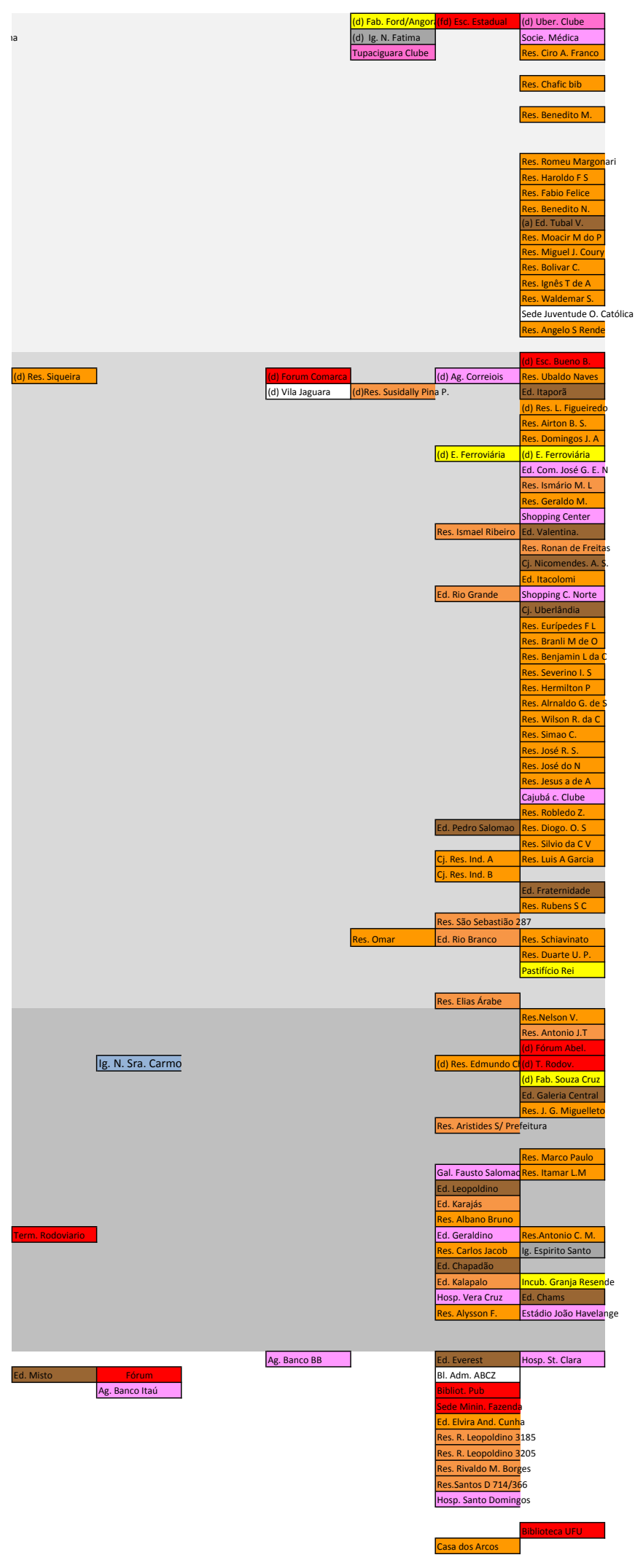

Residencial

Misto (RES + COM)

Serviços Publicos/Estado

Industrial Privado/ Ferroviário

Praças/Paisagismo

\begin{tabular}{l} 
Religioso \\
\hline Desconhecido/ Não Ident.
\end{tabular}

(d) - Década (sem data específica/aproximada)

(a) - Data aproximada

Tipologias originais do projeto

Datas do projeto 


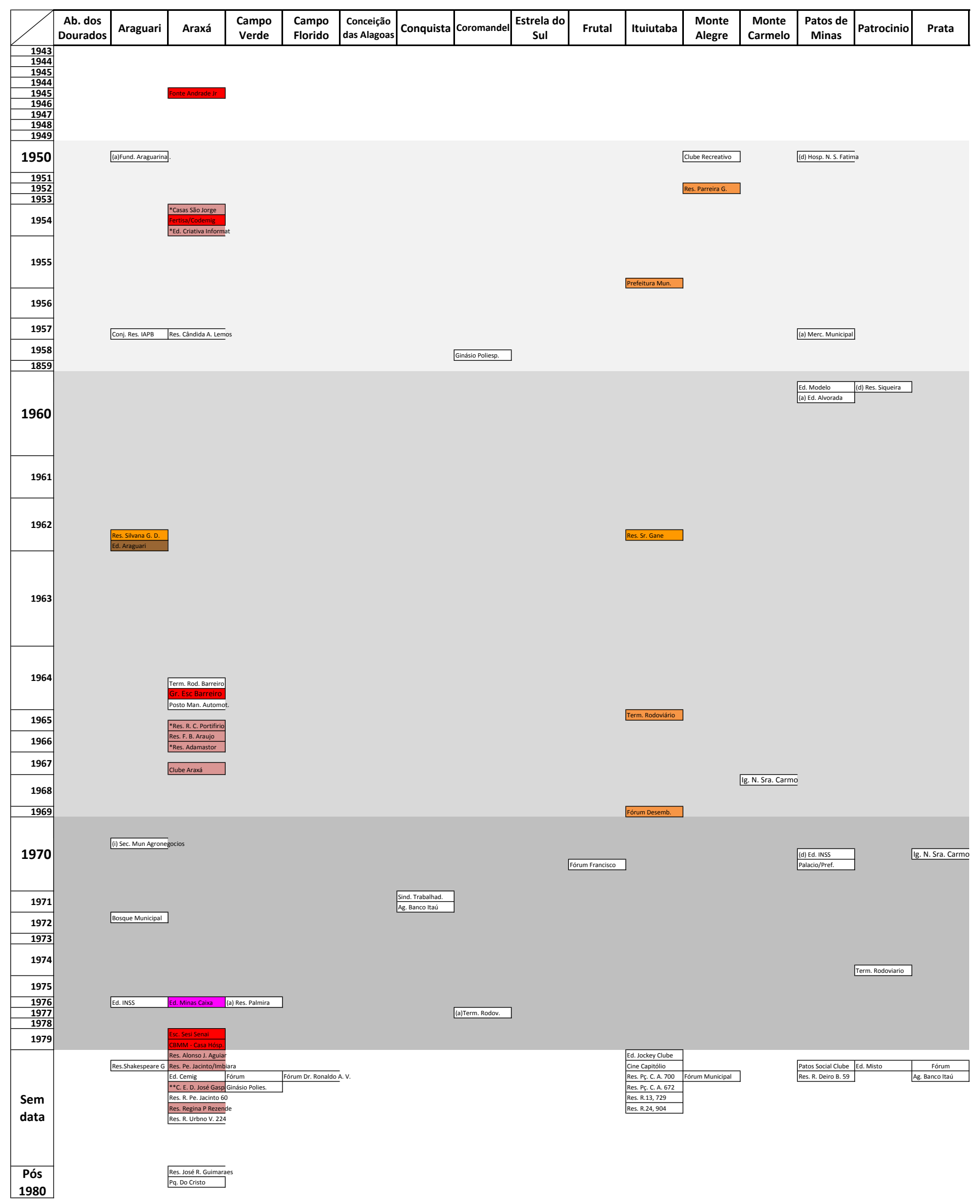

Arquitetura Moderna no Triângulo Mineiro e Alto Paranaíba Tabela: Data x Cidade x Autoria 


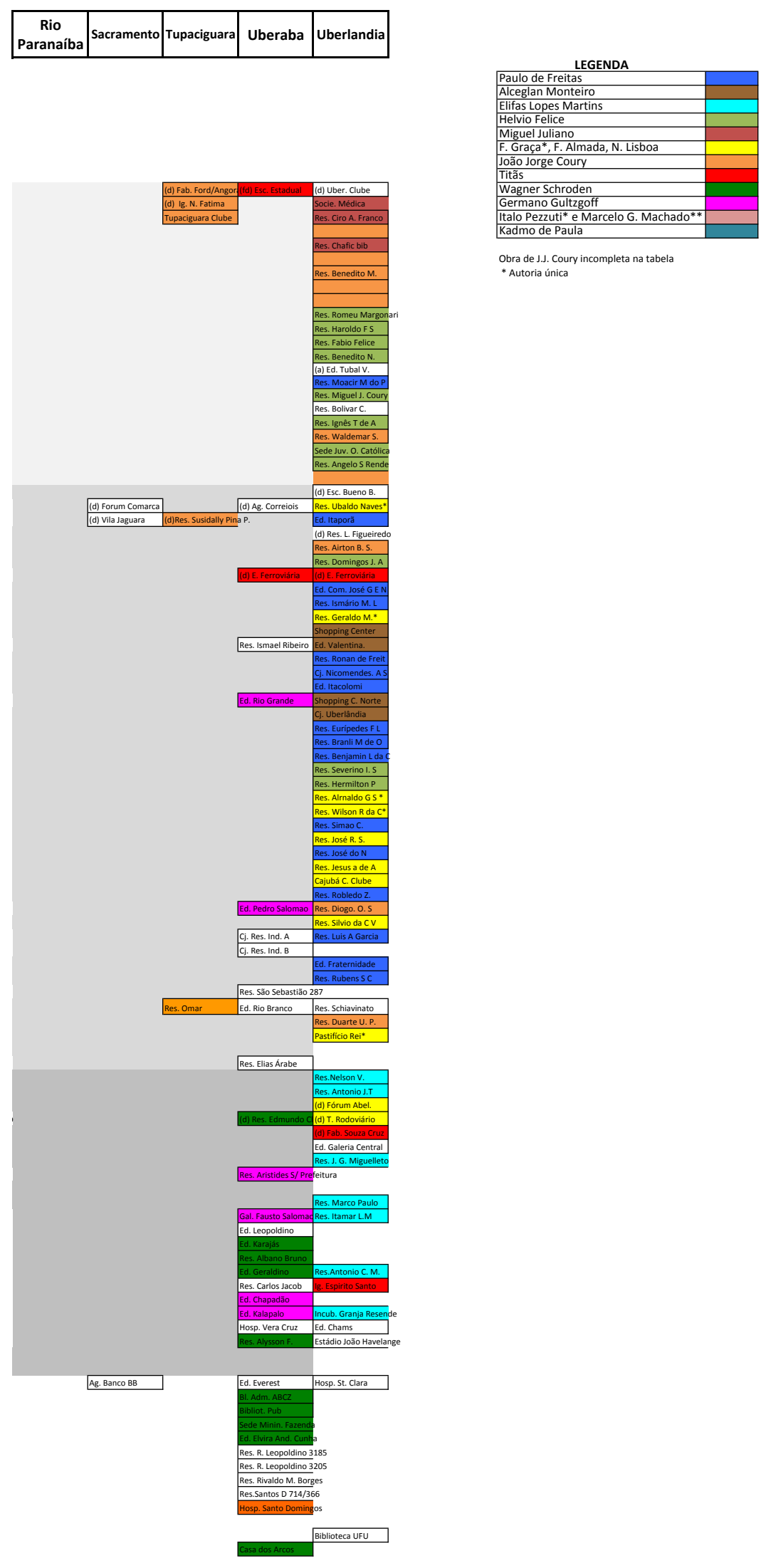

